\title{
ANÁLISE MICROSCÓPICA DOS FENÔMENOS TECIDUAIS DA MOVIMENTAÇÃO DENTÁRIA INDUZIDA EM RATOS NO PERÍODO DE UM A SETE DIAS
}

\section{ANDREA REIS DA COSTA}

Tese apresentada a Faculdade de Odontologia de Bauru da Universidade de São Paulo, como parte dos requisitos necessários para obtenção do título de Doutor em Odontologia, área de Patologia Bucal.

Orientador: Prof. ${ }^{\circ}$ Dr. ${ }^{\circ}$ Luís Antônio de Assis Taveira

(Edição Revisada) 


\section{ANÁLISE MICROSCÓPICA DOS FENÔMENOS TECIDUAIS DA MOVIMENTAÇÃO DENTÁRIA INDUZIDA EM RATOS NO PERÍODO DE UM A SETE DIAS}

\section{ANDREA REIS DA COSTA}

Tese apresentada a Faculdade de Odontologia de Bauru da Universidade de São Paulo, como parte dos requisitos necessários para obtenção do título de Doutor em Odontologia, área de Patologia Bucal.

Orientador: Prof. ${ }^{\circ}$ Dr. ${ }^{\circ}$ Luís Antônio de Assis Taveira

(Edição Revisada) 


\begin{tabular}{|l|}
\hline Costa, Andrea Reis da \\
C823d Análise microscópica dos fenômenos teciduais da movimentação \\
dentária induzida em ratos no período de um a sete dias/ Andrea Reis \\
da Costa - Bauru, 2004. \\
129p.: il. $28 \mathrm{~cm}$. \\
Tese. (Doutorado) - Faculdade de Odontologia de Bauru. USP. \\
Orientador: Prof ${ }^{\text {. Dr }}{ }^{\text {. }}$. Luís Antônio de Assis Taveira
\end{tabular}

Autorizo, exclusivamente para fins acadêmico e científico, a reprodução total ou parcial desta tese, por processos fotocopiadores e outros meios eletrônicos.

Bauru, 18 de fevereiro de 2004.

Projeto de Pesquisa aprovado pelo Comitê de Ética na Experimentação Animal da Faculdade de Odontologia da Universidade Estadual Paulista na reunião do dia 12 de junho de 2002 . 


\section{DADOS PESSOAIS}

09/ 02/ 1972

1993-1997

1998-2000

2000-2002

2002-2004
Nascimento em Recife - PE

Graduação na Universidade Federal de Pernambuco.

Mestrado em Odontologia, área de Patologia Oral na Universidade Federal do Rio Grande do Norte.

Professora Substituta de Patologia Oral na Universidade Federal de Pernambuco.

Doutorado em Odontologia, área de Patologia Bucal na Faculdade de Odontologia de Bauru da Universidade de São Paulo. 


\section{AGRADECIMENTOS}

À DEUS, inteligência suprema, causa primária de todas as coisas.

Leitão e Nilda, muito mais que pais, são grandes educadores, incentivadores, amigos e fãs de seus três filhos. Com vocês aprendi que a vida profissional é muito importante, no entanto, se não houver laços de família, laços de amor e laços de humanidade para com o próximo, o grande profissional não existirá.

Adriana, Arthur, Angela e Annalice, a família é primordial para o crescimento humano,

Ao Prof ${ }^{0}$. Dr ${ }^{0}$. Luís Antônio de Assis Taveira, pela paciência, compreensão e total apoio profissional para o desenvolvimento deste trabalho.

Às professoras Denise e Vanessa que tão bem souberam desempenhar o papel de educadora, pesquisadora e amiga. Lamento nosso pouco convívio e enalteço vossa dedicação irrestrita à formação profissional e ética de seus alunos!

Aos funcionários e suas respectivas famílias Berna, Cris, Fatiminha, Richard e o Bonitão Valdir, pela amizade, dedicação e desenvoltura no dia-a-dia.

Aos Funcionários da Seção de Pós-Graduação: Giane Tenório Quintela, Ana Letícia Palombo Momesso, Margareth Pereira Mokarzel e Jéferson de Oliveira Melo.

Aos meus amigos Adrianinha, Antonio Alfredo, Elaine, Gleicy, Gustavo, Jurema, Robson e Sandra. A distância só serviu para nos mostrar que estamos cada vez mais próximos.

À Prof ${ }^{a}$. da UFPE Jurema Lisboa, minha gratidão pelo apoio e incentivo destinados à sua equipe, sendo a grande responsável pelo meu apreço à Patologia Bucal e despertar para o aprofundamento de meus conhecimentos. Esta Tese é uma das conseqüências de um trabalho iniciado há 10 anos, como sua aluna do $4^{\circ}$ período da graduação.

À minha família Update. Tereza, Márcio, Nair, Alcides, Valéria, Victor Hugo, Regina, Fernando, Adriana e Letícia - The beginning of wisdom is silence. 
Aryela, Dalva e Silvana "na vida não existe antecipação nem adiamento, somente o tempo propício de cada um" (Hammed).

Renata, a minha Renata, Luzinha e Rosário. "Que bobagem falar que é nas grandes ocasiões que se conhece os amigos! Nas grandes ocasiões é que não faltam amigos. Principalmente neste Brasil de coração mole e escorrendo. E a compaixão, a piedade, a pena, se confundem com amizade. Por isso tenho horror das grandes ocasiões. Prefiro as quartas-feiras." (Mário de Andrade).

Aos colegas da pós-graduação Álica Carolina, Aline, Betânia, Camila, Christian, Érick, João Adolfo, Leda, Lídia, Lidiane, Luciana, Marta, Patrícia, Renata F., Renato, Rosa, Rosário, Suzana, Tiago e Valdomiro.

À Christian, Fatiminha, Fernanda e Tânia pela contribuição prestada à parte experimental desta pesquisa.

Aos Funcionários do Serviço de Biblioteca e Documentação.

Aos colegas Pós-Graduandos dos demais Departamentos.

\section{AGRADECIMENTOS INSTITUCIONAIS}

À Faculdade de Odontologia de Bauru, Universidade de São Paulo, na pessoa da Diretora Maria Fidela de Lima Navarro.

À Comissão de Pós-Graduação da FOB/ USP, na pessoa do Presidente, Prof. Dr. José Carlos Pereira.

Ao Departamento de Estomatologia da FOB/ USP, na pessoa do chefe Prof. Dr. Alberto Consolaro.

À CAPES pelo auxílio pecuniário. 
“ É fundamental diminuir a distância entre o que se diz e o que se faz, de tal maneira que, num dado momento, a tua fala seja a tua prática."

Paulo Freire 


\section{SUMÁRIO}

Lista de Figuras

Páginas

Lista de Abreviaturas

vii

Resumo

$\mathrm{x}$

1 Introdução e Síntese Bibliográfica Xi

2 Proposição 28

3 Material e Métodos 30

3.1 Seleção da Amostra 31

3.2 Distribuição da Amostra 31

$\begin{array}{lll}3.3 & \text { Preparo do Aparelho } & 32\end{array}$

3.4 Anestesia dos Animais 32

3.5 Instalação e Ativação dos Aparelhos __ 33

3.6 Morte dos animais, obtenção e preparo dos espécimes __ 34

$\begin{array}{llll}3.7 & \text { Processamento histotécnico das peças cirúrgicas } & \\ 3.8 & \end{array}$

3.8 Análise microscópica 35

3.8.1 Fenômenos Analisados 35

3.9 Análise Estatística 36

4 Resultados 39

5 Discussão 63

6 Conclusão 78

Referências Bibliográficas 80

Abstract

Anexos 97

Apêndice 126 


\section{LISTA DE FIGURAS}

Figura 1 - Desenho esquemático de aparelho proposto por HELLER; NANDA 58 em 1979, à esquerda. Foto do aparelho posicionado em rato ligando o incisivo e o primeiro molar esquerdo superior, à direita

Figura 2 - Distribuição dos achados microscópicos referentes aos fenômenos morfologicamente detectados nos animais do Grupo ME ou MC

Figura 3 - Fotomicrografia panorâmica da raiz mesiovestibular do primeiro molar superior do Grupo Controle. As regiões marcadas corresponderão, nos Grupos Experimentais, aos lados de compressão e de tensão. $\mathrm{C}=$ lado de compressão; $\mathrm{T}$ = lado de tensão (Coloração H. E.; aumento Original $-50 x)$

Figura 4 - Região cervical do lado mesial da raiz mesiovestibular do Grupo Controle. Notam-se ligamento periodontal ricamente celularizado; superfície óssea periodontal regular, parcialmente revestida por osteoblastos, e crista alveolar arredondada; superfície cementária uniforme, revestida por cementoblastos. $\mathrm{O}=$ osso; $\mathrm{L}=$ ligamento periodontal; D = dente (Coloração H. E.; Aumento Original - 100x)

Figura 5 - Resto epitelial de Malassez localizado no ligamento periodontal. $\mathrm{D}=$ dente; $\mathrm{L}=$ ligamento periodontal; $\mathrm{M}$ - ilhota epitelial de Malassez (Coloração H.E.; Aumento Original - 400x)

Figura 6 - Região cervical do lado de tensão da raiz mesiovestibular do Grupo 1. Notam-se ligamento periodontal ricamente celularizado, com fibras colágenas tensionadas; superfície óssea irregular apresentando linhas de reversão. $\mathrm{O}=$ osso; $\mathrm{L}=$ ligamento periodontal; $\mathrm{D}=$ dente (Coloração $\mathrm{H}$. E.; Aumento Original - 100x)

Figura 7 - Região cervical do lado de compressão da raiz mesiovestibular do Grupo 1. Notam-se ligamento periodontal ricamente celularizado; superfície óssea periodontal levemente recortada no terço médio com e crista alveolar arredondada; superfície cementária uniforme, revestida por cementoblastos. $\mathrm{O}=$ osso; $\mathrm{L}=$ ligamento periodontal; $\mathrm{D}=$ dente (Coloração H. E.; Aumento Original - 100x)

Figura 8 - Maior aumento da área irregular da superfície óssea periodontal evidenciando cavidades reabsortivas inativas e linhas de reversão. $\mathrm{O}=$ osso; $\mathrm{L}=$ ligamento periodontal; $\mathrm{R}=$ linhas de reversão (Coloração $\mathrm{H}$. E.; Aumento Original - 400x)

Figura 9 - Região cervical do lado de tensão da raiz mesiovestibular do Grupo 2. Notam-se ligamento periodontal ricamente celularizado; superfície óssea periodontal uniforme em seu terço superior sem lacunas de reabsorção; superfície cementária uniforme, revestida por cementoblastos. $\mathrm{O}=$ osso; $\mathrm{L}=$ ligamento periodontal; $\mathrm{D}=$ dente 
Figura 10 - Região apical do lado de compressão da raiz mesiovestibular no Grupo 2. Notam-se ligamento periodontal com espessura diminuída; superfície óssea irregular. $\mathrm{O}=$ osso; $\mathrm{L}=$ ligamento periodontal; $\mathrm{D}=$ dente (Coloração H. E.; Aumento Original - 100x)

Figura 11 - Maior aumento da área de compressão apical do Grupo 2. Notam-se ligamento periodontal com fibroblastos em disposição aleatória, além das pequenas áreas hialinas; superfície óssea revestida parcialmente por osteoblastos com presença de um osteoclasto à distância; superfície cementária uniforme. $\mathrm{O}=$ osso; $\mathrm{L}=$ ligamento periodontal; $\mathrm{D}=$ dente; $\mathrm{H}=$ área hialina (Coloração H. E.; Aumento Original - 400x)

Figura 12 - Região cervical do lado de tensão da raiz mesiovestibular do Grupo 3. Notam-se ligamento periodontal ricamente celularizado; superfície óssea periodontal regular; superfície cementária uniforme. $\mathrm{O}=$ osso; $\mathrm{L}$ = ligamento periodontal; $\mathrm{D}=$ dente (Coloração H. E.; Aumento Original - 100x)

Figura 13 - Região cervical do lado de compressão da raiz mesiovestibular do Grupo 3. Notam-se ligamento periodontal com espessura diminuída, ricamente celularizado; superfície óssea periodontal com áreas de irregularidade, linhas de reversão e crista alveolar afilada; superfície cementária uniforme, revestida por cementoblastos. $\mathrm{O}=$ osso; $\mathrm{L}=$ ligamento periodontal; $\mathrm{D}=$ dente (Coloração H. E.; Aumento Original $-100 x)$

Figura 14 - Maior aumento da área de compressão cervical do Grupo 3. Notam-se ligamento periodontal ricamente celularizado com pequenas áreas hialinas; superfície óssea periodontal com unidades de reabsorção alternadas; superfície cementária uniforme, revestida por cementoblastos. $\mathrm{O}=$ osso; $\mathrm{H}=$ área hialina; $\mathrm{D}=$ dente, $\mathrm{U}=$ unidade de reabsorção (Coloração H. E.; Aumento Original - 400x)

Figura 15 - Região cervical do lado de tensão da raiz mesiovestibular do Grupo 4. Notam-se ligamento periodontal ricamente celularizado, com pontos focais de hemorragia e discreta congestão vascular; superfície óssea periodontal com áreas de irregularidade; superfície cementária uniforme, revestida por cementoblastos. $\mathrm{O}=$ osso; $\mathrm{L}=$ ligamento periodontal; D = dente (Coloração H. E.; Aumento Original - 100x)

Figura 16 - Região cervical do lado de compressão da raiz mesiovestibular do Grupo 4. Notam-se ligamento periodontal ricamente celularizado; superfície óssea periodontal regular com poucas linhas de reversão; superfície cementária uniforme. $\mathrm{O}=$ osso; $\mathrm{L}=$ ligamento periodontal; $\mathrm{D}=$ dente (Coloração H. E.; Aumento Original - 100x)

Figura 17 - Região cervical do lado de tensão da raiz mesiovestibular do Grupo 5. Notam-se ligamento periodontal ricamente celularizado com fibras colágenas distendidas; superfícies óssea periodontal e cementária 
uniformes. $\mathrm{O}=$ osso; $\mathrm{L}=$ ligamento periodontal; $\mathrm{D}=$ dente (Coloração H. E.; Aumento Original - 100x)

Figura 18 - Região cervical do lado de compressão da raiz mesiovestibular do Grupo 5. Notam-se ligamento periodontal ricamente celularizado; superfície óssea periodontal recortada com unidades de reabsorção e crista alveolar irregular; superfície cementária uniforme. $\mathrm{O}=$ osso; $\mathrm{L}=$ ligamento periodontal; D = dente (Coloração H. E.; Aumento Original $-100 x)$

Figura 19- Maior aumento da região de compressão do Grupo 5. Notam-se discretas áreas hialinas, unidades de reabsorção e múltiplos vasos sangüíneos. $\mathrm{O}=$ osso; $\mathrm{L}=$ ligamento periodontal; $\mathrm{D}=$ dente; $\mathrm{U}=$ unidade de reabsorção (Coloração H. E.; Aumento Original - 400x)

Figura 20 - Região cervical do lado de tensão da raiz mesiovestibular do Grupo 6. Notam-se ligamento periodontal ricamente celularizado, com fibras colágenas estiradas; superfícies óssea periodontal e cementária uniformes. $\mathrm{O}=$ osso; $\mathrm{L}=$ ligamento periodontal; $\mathrm{D}=$ dente (Coloração H. E.; Aumento Original - 100x)

Figura 21 - Região cervical do lado de compressão da raiz mesiovestibular do Grupo 6. Notam-se ligamento periodontal ricamente celularizado; superfície óssea periodontal recortada com crista alveolar afilada; superfície cementária uniforme, revestida por cementoblastos. $\mathrm{O}=$ osso; L = ligamento periodontal; $\mathrm{D}=$ dente (Coloração H. E.; Aumento Original - 100x)

Figura 22 - Maior aumento da região de compressão do Grupo 6. Notam-se ligamento periodontal ricamente celularizado, com discretas áreas hialinas; superfície óssea periodontal com unidades de reabsorção; superfície cementária uniforme, revestida por cementoblastos. $\mathrm{O}=$ osso; $\mathrm{L}=$ ligamento periodontal; $\mathrm{D}=$ dente (Coloração H. E.; Aumento Original - 400x)

Figura 23 - Região cervical do lado de tensão da raiz mesiovestibular do Grupo 7 (seta). Notam-se ligamento periodontal ricamente celularizado, com fibras colágenas distendidas; superfície óssea periodontal discretamente ondulado; superfície cementária uniforme. $\mathrm{O}=$ osso; $\mathrm{L}=$ ligamento periodontal; D = dente (Coloração H. E.; Aumento Original $-100 x)$

Figura 24 - Região cervical do lado de compressão da raiz mesiovestibular do Grupo 7. Notam-se ligamento periodontal com espessura diminuída, ricamente celularizado; superfície óssea periodontal com aspecto de normalidade; superfície cementária uniforme. $\mathrm{O}=$ osso; $\mathrm{L}=$ ligamento periodontal; D = dente (Coloração H. E.; Aumento Original - 100x) 


\section{LISTA DE ABREVIATURAS}

AMPc - adenosina monofosfato

BGP - osteocalcina

BMU - unidade osteorremodeladora

$\mathrm{Ca}^{2+}-$ cálcio

CFU-GM - unidade formadora de colônia - granulócitos e macrófagos

CDF - fatores estimuladores de colônia

CGRP - neuropeptídeo relacionado ao gene da calcitonina

ecNOS - óxido nítrico sintase produzido por célula endotelial

EGF - fator de crescimento epidérmico

FGF - fator de crescimento fibroblástico

GAP - proteína associada ao crescimento

GMP - guanilil monofosfato

IGF - fator de crescimento insulina-like

iNOS - óxido nítrico sintase produzido por células por ação das citocinas inflamatórias ou endotoxinas bacterianas

Junção gap - regiões especializadas da membrana celular que se conectam com células adjacentes e promovem movimento bidirecional de pequenas moléculas e íons

NOS - óxido nítrico sintase

nNOS - óxido nítrico sintase produzido por célula nervosa

OG - genes relacionados à osteocalcina expresso no osso

OGR - genes relacionados à osteocalcina expresso no rim 
PDGF - fator de crescimento derivado de plaqueta

$\mathbf{T G F}_{\boldsymbol{\beta}}$ - fator de crescimento transformador beta

TNF - fator de necrose tumoral

TRAP - fosfatase alcalina tartarato resistente

VEGF - fator de crescimento endotélio vascular 


\section{RESUMO}

A movimentação dentária induzida é um processo biológico múltiplo caracterizado por reações seqüenciais do tecido periodontal em resposta às forças biomecânicas. As modificações teciduais induzidas estão relacionadas à sua remodelação por ativação da reabsorção óssea alveolar no lado de pressão e conseqüente aposição óssea no lado de tensão. Os estímulos gerados em resposta ao estresse mecânico durante a movimentação dentária induzida medeiam alterações teciduais que em conjunto com a ativação dos mediadores químicos resultam em nova condição homeostática do periodonto, que são hialinização, remodelação e reabsorção. Visando estabelecer um tempo ideal para observação das alterações ocorridas desde o início da movimentação dentária induzida experimental, traçou-se um perfil morfológico tecidual diário, desde as fases iniciais do movimento dentário induzido em ratos, utilizando-se como controle os dentes não movimentados do lado oposto, considerando-se: os aspectos de normalidade (lado controle) e os fenômenos microscópicos observados durante o movimento dentário induzido, desde as fases iniciais, descrevendo-os minuciosamente; a intensidade e extensão da reabsorção óssea; e a intensidade e extensão da reabsorção dentária. A amostra constituiu-se de 21 ratos submetidos à movimentação dentária induzida por 1 a 7 dias, utilizando-se o aparelho proposto por HELLER; NANDA. Com base nas constatações e levando-se em consideração a metodologia utilizada, concluiu-se que: as alterações morfológicas celulares e teciduais no periodonto dos dentes submetidos a estresse mecânico não sofreram grandes variações entre os grupos para este modelo experimental; as alterações morfológicas nos lados de compressão e tensão periodontal foram intensificadas gradualmente à medida que avançava o período experimental, sem, no entanto, ocorrer reabsorção dentária; o tempo ideal de movimentação dentária induzida em ratos compreende o período onde há um equilíbrio entre a força aplicada e as alterações morfológicas não destrutivas irreversivelmente obtidas. Neste experimento, o quinto dia após a aplicação da força. 
1 INTRODUÇÃO E SÍNTESE BIBLIOGRÁFICA 


\section{INTRODUÇÃO E SÍNTESE BIBLIOGRÁFICA}

Desde que SANDSTEDT ${ }^{144}$, em 1904, apud HELLER; NANDA ${ }^{58}$, 1979, relatou as alterações no periodonto de cães durante a movimentação dentária, este tema tem sido discutido por muitos autores. Ele percebeu que aplicando força sobre os dentes, as mudanças celulares tornavam-se mais intensas e induziam reabsorção dentária (MACAPANPAN; WEINMANN; BRODIE ${ }^{101}$, 1954, AZUMA ${ }^{9}, 1970$, WILLIAMS ${ }^{195}, 1984$ e KOHNO et al. ${ }^{85}, 2002$ ).

Muitas teorias sobre movimentação dentária induzida foram propostas, todas tendo a reabsorção óssea como um dos efeitos biológicos (KUFTINEC ${ }^{86}, 1968$ e HELLER; NANDA $\left.{ }^{58}, 1979\right)$. Na primeira metade do século XX, já existia a preocupação sobre o mecanismo de atuação e desencadeamento da força aplicada sobre a coroa dentária. A teoria pressão-tensão baseava-se na vitalidade do ligamento periodontal, ou seja, o estímulo exercido sobre o ligamento não envolvia ou requeria estímulo advindo de outra estrutura, como o osso alveolar, por exemplo. As fibras colágenas e o sistema vascular eram essenciais para esse sistema (SANDSTEDT ${ }^{144}$, 1904, apud HELLER; NANDA ${ }^{58}$, 1979). Outra teoria baseava-se na distorção do osso alveolar provocada pela indução de força através de um mecanismo de pressãotensão mediado por fibras (BAUMRIND; BUCK ${ }^{14}$, 1970, GRIMM ${ }^{53}, 1972$ e HELLER; NANDA ${ }^{58}$, 1979). Uma combinação dessas teorias era possível. A distorção óssea poderia ser um estímulo primário, mas a presença do ligamento periodontal era necessária para transferência da força inicial (ZENGO; PAWLUK; BASSETT $^{203}, 1973$ e HELLER; NANDA $\left.{ }^{58}, 1979\right)$.

O periodonto de sustentação não é um tecido homogêneo e isotrópico, mas um sistema complexo de células, fibras, matriz e componentes neurovasculares composto pelo cemento, ligamento periodontal e osso alveolar. É responsável pela manutenção da posição dentária e pela distribuição das forças mastigatórias ao osso alveolar (McCULLOCH; MELCHER ${ }^{109}$, 1983, LASFARGUES; SAFFAR ${ }^{92}, 1993$, LEKIC et al. ${ }^{94}, 1997$ e CHO; GARANT $\left.{ }^{31}, 2000\right)$. 
Explicar a movimentação dentária relacionando às propriedades do ligamento periodontal é uma tarefa que muitos investigadores têm se ocupado (REITAN; KVAM ${ }^{133}$, 1971, KYOMEN; TANNE ${ }^{90}$, 1997, YOKOYA; SASAKI; SHIBASAKI ${ }^{200}, 1997$, CHANTAWIBOONCHAI et al. ${ }^{28}, 1998$ e MABUCHI; MATSUZAKA; SHIMONO $\left.{ }^{100}, 2002\right)$.

A movimentação dentária induzida é um processo biológico múltiplo caracterizado por reações seqüenciais do tecido periodontal em resposta às forças biomecânicas que induzem alteração em duas regiões do tecido periodontal: o lado de compressão e o lado de tensão. As modificações teciduais induzidas estão relacionadas à remodelação tecidual por ativação da reabsorção óssea alveolar no lado de compressão e conseqüente aposição óssea no lado de tensão (MACAPANPAN; WEINMANN; BRODIE ${ }^{101}$, 1954, WALDO; ROTHBLATT ${ }^{189}$, 1954, ZAKI; VAN HUYSEN ${ }^{202}$, 1963, AZUMA ${ }^{9}, 1970$, REITAN ${ }^{132}, 1974$, RYGH 140, 1976, HELLER; NANDA ${ }^{58}$, 1979, MIDGETT; SHAYE; FRUGE ${ }^{113}, 1981$, ROBERTS; CHASE ${ }^{135}$, 1981, WILLIAMS ${ }^{195}$, 1984, DUCY et al. 35, 1996, ASHIZAWA; SAHARA ${ }^{3}$, 1998, NAGAI et al. ${ }^{117}$, 1999, VERNA; ZAFFE; SICILIANI ${ }^{186}$, 1999, TOMS; GANNON; CARATI ${ }^{172}$, 2000, KAKU et al. ${ }^{75}, 2001$, HAMAYA et al. ${ }^{55}, 2002$, SHIRAZI et al. ${ }^{154}, 2002$ e KOHNO et al. ${ }^{84}, 2003$ ).

A inflamação é um importante co-requisito para a movimentação dentária induzida. A ativação de células inflamatórias e a conseqüente liberação de mediadores apresentam importante função sobre os tecidos mineralizados (TØNDER ${ }^{173}, 1983$ e LARA et al. $\left.{ }^{91}, 2003\right)$. Alterações celulares e vasculares, mediadores inflamatórios, fatores de crescimento e neuropeptídeos têm sido identificados no tecido que circunda o dente sujeito à forças induzidas (COOPER; SIMS ${ }^{34}, 1989$, VANDEVSKA-RADUNOVIC et al. ${ }^{183}$, 1994). A fase inicial da movimentação dentária estimula a liberação de fatores químicos e elétricos das fibras nervosas sensoriais e desencadeiam resposta inflamatória que modifica a microcirculação, promovendo vasodilatação periodontal acompanhada por migração de leucócitos a partir dos capilares sangüíneos (VANDEVSKA-RADUNOVIC; KVINNSLAND; KVINNSLAND ${ }^{181}, 1998$, OGAWA et al. ${ }^{120}, 2002$ e PERINETTI et al. ${ }^{128}, 2002$ ). Os mecanismos neurogênicos apresentam importante função durante a inflamação 
provocada pela movimentação dentária experimental. A aplicação de forças estimula os mecanorreceptores do ligamento periodontal, que ao serem ativados liberam neuropeptídeos e, pelo mecanismo reflexo, desencadeiam resposta inflamatória (KVINNSLAND; KVINNSLAND ${ }^{88}, \quad 1990, \quad$ FRISTAD; HEYERAAS; KVINNSLAND ${ }^{42}$, 1994, FRISTAD et al. ${ }^{43}, 1995$ e TOMS; GANNON; CARATI $\left.{ }^{172}, 2000\right)$.

A aplicação da força produz reações teciduais que estão associadas a fatores locais relacionados aos dentes e a oclusão, e também a fatores sistêmicos relacionados ao metabolismo ósseo (VERNA; MELSEN 185, 2003). Estas modificações serão contínuas até que a força aplicada seja completamente dissipada (HELLER; NANDA ${ }^{58}$, 1979). São bem conhecidas as alterações que a movimentação dentária induzida provoca nos tecidos, no entanto faltam trabalhos com descrição minuciosa das alterações morfológicas geradas (MABUCHI; MATSUZAKA; SHIMONO $\left.{ }^{100}, 2002\right)$.

Microscopicamente, no lado de compressão do ligamento periodontal, os seguintes eventos biológicos são descritos: distúrbio no fluxo sangüíneo, necrose, morte celular, fagocitose dos restos celulares, hialinização tecidual, estreitamento da largura do ligamento periodontal, reabsorção óssea nas proximidades das áreas hialinizadas por osteoclastos multinucleados associados a pequenas lacunas de Howship (MACAPANPAN; WEINMANN; BRODIE ${ }^{101}$, 1954, KUFTINEC ${ }^{86}$, 1968, RYGH ${ }^{137}, 1972,{ }^{139}, 1974,{ }^{140}, 1976 \mathrm{e}^{142}, 1986$, HELLER; NANDA ${ }^{58}, 1979$, KOBAYASHI et al. ${ }^{83}$, 1998, HAMAYA et al. ${ }^{55}$, 2002, MABUCHI; MATSUZAKA; SHIMONO ${ }^{100}, 2002$ e TALIC et al. $\left.{ }^{166}, 2003\right)$.

No lado tensionado, o espaço periodontal torna-se amplo com figuras de mitose e aumento do número de células, resultando em atividade osteoblástica com deposição de tecido osteóide e sua posterior mineralização, além da remodelação das fibras colágenas (MACAPANPAN; WEINMANN; BRODIE ${ }^{101}, 1954$, KUFTINEC 86, 1968, AZUMA 9, 1970, TEN CATE ${ }^{170}, 1976$, RYGH ${ }^{140}, 1976 \mathrm{e}^{142}, 1986$, HELLER; NANDA ${ }^{58}$, 1979, McCULLOCH; MELCHER 110 e 111, 1983, KOBAYASHI et al. ${ }^{83}$, 1998, HAMAYA et al. ${ }^{55}, 2002$ e MABUCHI; MATSUZAKA; SHIMONO $\left.{ }^{100}, 2002\right)$. 
O molar de rato tem sido largamente utilizado como modelo para estudos sobre as alterações vasculares associados com movimentação dentária. Este dente apresenta crescimento limitado com desenvolvimento e irrompimento similar ao humano, embora se movimente distalmente sob condições fisiológicas (MACAPANPAN; WEINMANN; BRODIE ${ }^{101}$, 1954, WALDO; ROTHBLATT ${ }^{189}$, 1954, BERNICK ${ }^{15}$, 1960, ZAKI; VAN HEYSEN ${ }^{202}$, 1963, AZUMA 9 , 1970, HELLER; NANDA ${ }^{58}$, 1979, TRAN VAN; VIGNERY; BARON ${ }^{174}$, 1982, WILLIAMS ${ }^{195}$, 1984, LEW ${ }^{97}, 1989$, KING et al. ${ }^{81}$, 1991, BRUDVIK; RYGH ${ }^{21}$, 1993, FUKUI ${ }^{44}, 1993$, VANDEVSKA-RADUNOVIC et al. ${ }^{183}$, 1994, RODRIGUEZ et al. ${ }^{136}, 1996$, ASHIZAWA; SAHARA ${ }^{3}$, 1998, VANDEVSKA-RADUNOVIC; KVINNSLAND; KVINNSLAND ${ }^{181}$, 1998, TSAY; CHEN; OYEN ${ }^{175}$, 1999, VERNA; ZAFFE; SICILIANI ${ }^{186}, 1999$, HASHIMOTO et al. ${ }^{56}, 2001$, KOHNO et al. ${ }^{84}$, 2002, MABUCHI; MATSUZAKA; SHIMONO ${ }^{100}$, 2002, SHIRAZI et al. ${ }^{154}$, 2002, TALIC et al. ${ }^{166}, 2003$ e VERNA; MELSEN ${ }^{185}, 2003$ ).

\subsection{Histologia do dente e periodonto de sustentação}

Para uma melhor compreensão a respeito do comportamento do ligamento periodontal mediante a movimentação dentária induzida é importante uma breve revisão sobre histologia do dente e do periodonto de sustentação do rato.

Os fibroblastos são as células mais abundantes do ligamento periodontal e são responsáveis pelo metabolismo dos componentes da matriz extracelular $(\mathrm{CHO}$; GRANT ${ }^{31}$, 2000). Os osteoblastos são derivados de precursores originários da medula óssea a partir das células-tronco mesenquimais (GRIGORIADIS et al. ${ }^{52}$, 1994 e JUNQUEIRA et al. $\left.{ }^{73}, 2001\right)$. Os osteócitos estão aprisionados na matriz óssea e constituem $90 \%$ de todas as células ósseas. Dentre suas funções citam-se o transporte de íons via seus processos citoplasmáticos, captação de cálcio, regulação da atividade osteoclástica, e provavelmente mecanotransdução (ROBERTS; CHASE ${ }^{135}, 1981$ e HAMAYA et al. $\left.{ }^{55}, 2002\right)$. 
Morfologicamente, os osteócitos formam complexa rede celular unida por junções tipo gap entre osteócitos vizinhos e/ ou osteoblastos da superfície óssea (SU et al. ${ }^{162}, 1997$ e HAMAYA et al. ${ }^{55}$, 2002). As junções gap são regiões especializadas da membrana celular que se conectam com células adjacentes e promovem movimento bidirecional de pequenas moléculas e íons incluindo segundos mensageiros como a adenosina monofosfato cíclico (AMPc), o inositol trifosfato e o cálcio $\left(\mathrm{Ca}^{2+}\right)$. As proteínas que constituem os canais das junções gap são da família da proteína chamada conexina, e o tipo 43 é predominante nessas junções ósseas (SU et al. $\left.{ }^{162}, 1997\right)$.

Os osteoclastos são derivados de células progenitoras hematopoéticas, embora haja dúvidas de sua origem se a partir de fagócitos mononucleares macrófago ou monócito - se a partir de um mesmo progenitor que origina os fagócitos mononucleares. Sabe-se que seus precursores diferenciam-se e atingem a maturidade na medula óssea (KAHN; SIMMONS ${ }^{74}, 1975$, MALONE et al. ${ }^{104}, 1982$, BARON et al. ${ }^{12}$, 1986, ALVAREZ et al. ${ }^{1}$, 1992, WANG et al. ${ }^{191}$, 1992, GRIGORIADIS et al. ${ }^{52}, 1994$ e TSAY; CHEN; OYEN $\left.{ }^{175}, 1999\right)$.

De acordo com MARKS JUNIOR ${ }^{106}$, 1983, a unidade formadora de colônia - granulócitos e macrófagos (CFU-GM) é o primeiro precursor do osteoclasto. Sua maturação segue os seguintes estádios: a CFU-GM, o pró-monócito e o pré-osteoclasto jovem estão presentes na medula óssea; o pré-osteoclasto maduro e osteoclasto, no ligamento periodontal, embora alguns pré-osteoclastos possam ser encontrados na circulação sangüínea periférica em futuros sítios de formação óssea. Os pré-osteoclastos locais estão livres e atuam sobre os tecidos inicialmente, e posteriormente, por movimentação dentária induzida contínua, os pré-osteoclastos sangüíneos são recrutados (TSAY; CHEN; OYEN ${ }^{175}$, 1999).

Os clastos são células gigantes multinucleadas que se originam através da fusão de precursores mononucleados derivados dos monócitos (MALONE et al. ${ }^{104}$, 1982, MARKS JUNIOR ${ }^{106}$, 1983, GRIGORIADIS et al. ${ }^{52}$, 1994 e TOMS; GANNON; CARATI ${ }^{172}$, 2000). O ligamento periodontal do rato é destituído de osteoclastos maduros em condições fisiológicas, entretanto, após a aplicação de 
força, eles aparecem em poucos dias no lado de compressão (HUGHES; KING ${ }^{62}$, 1998 e TSAY; CHEN; OYEN $\left.{ }^{175}, 1999\right)$.

As células de Schwann apresentam importante função durante a remodelação dos nervos periféricos, além de estarem associadas às terminações nervosas de Ruffini (ATSUMI et al. ${ }^{4}, 1999 \mathrm{e}^{6 \text { e } 7}, 2000$ ).

Os restos epiteliais de Malassez são remanescentes da bainha radicular de Hertwig. Após a sua fragmentação as células tornam-se parte do ligamento periodontal. Algumas delas são incorporadas ao cemento e algumas permanecem próximas à superfície radicular (REITAN ${ }^{130}$, 1961, JOHANSEN ${ }^{69}, 1970$, WESSELINK; BEERTSEN ${ }^{193}, 1993$ e TALIC et al. $\left.{ }^{166}, 2003\right)$. Sua função não está totalmente esclarecida, mas sabe-se que participa da síntese e secreção de colagenase, enquanto que os fibroblastos periodontais sintetizam colágeno e inibidores da colagenase (TALIC et al. $\left.{ }^{166}, 2003\right)$. Os restos de Malassez apresentam função de proteção à estrutura radicular contra alterações reabsortivas e manutenção do espaço periodontal (REITAN ${ }^{130}$, 1961, WESSELINK; BEERTSEN ${ }^{193}, 1993$ e CONSOLARO $\left.^{33}, 2002\right)$.

SELVIG $^{152}, 1963 \mathrm{e}^{153}, 1964$ estudaram a estrutura das fibras periodontais e sua aderência ao cemento. O ligamento periodontal é constituído por dois tipos de fibras: as colágenas e as oxitalânicas (CHANTAWIBOONCHAI et al. ${ }^{28}$, 1998). O colágeno é o principal componente dos elementos fibrosos no ligamento periodontal. Sua função é resistir ao estresse de tensão, enquanto as proteoglicanas da matriz extracelular resistem às forças compressivas (TALIC et al. ${ }^{166}, 2003$ ).

O metabolismo das fibras colágenas no periodonto do molar de rato é muito rápido (OHKAWA ${ }^{121}$, 1982, TSURUTA et al. ${ }^{177}$, 1982, SCHELLENS; EVERTS; BEERTSEN ${ }^{148}, 1979 \mathrm{e}^{149}, 1982$ e OHSHIMA et al. ${ }^{122}$, 1991). A degradação das fibras colágenas velhas, a síntese de novas fibras e sua remodelação no ligamento periodontal são realizadas pelo fibroblasto após a indução da movimentação dentária para manutenção da nova relação dente-osso estabelecida (AZUMA $^{9}, 1970$, RYGH $^{139}, 1974 \mathrm{e}^{142}, 1986$, TEN CATE ${ }^{170}, 1976$, CHO; GRANT ${ }^{31}, 2000$ e TALIC et al. ${ }^{166}, 2003$ ). 
As fibras oxitalânicas foram reportadas no ligamento periodontal. Elas apresentam inserção cementária e, raramente, alveolar (FULLMER; SHEETZ; NARKATES ${ }^{46}$, 1974). CARMICHAEL ${ }^{24}, 1968$ descreveu sua distribuição e conexão na mandíbula de rato e observou que elas não se inserem no osso alveolar como descrito por FULLMER ${ }^{45}$, 1966, mas coordenam o movimento do dente em relação à vascularização periodontal (SIMS ${ }^{157}, 1973$ ). Elas são ubíquas e constituem um significativo componente do ligamento periodontal. Não estão associadas com a elastina e são compostas por fibrilina, microfibrila associada à glicoproteína, à proteoglicana, à fibronectina e à substância P (BREATHNACH et al. ${ }^{18}, 1981$, INOUÉ $^{66}$, 1986, EVERTS et al. ${ }^{39}, 1998$ e TASHIRO et al. $\left.{ }^{169}, 2002\right)$. Sua função ainda não está bem estabelecida, no entanto é possível que desempenhe função de ancoragem, manutenção da elasticidade, guia para migração celular, estabilização dos vasos sangüíneos e regulação do fluxo vascular (SIMS ${ }^{157}, 1973,{ }^{158}, 1975 \mathrm{e}^{159}$, 1976, FULLMER; SHEETZ; NARKATES ${ }^{46}$, 1974, SHORE; BERKOVITZ ${ }^{155}$, 1978, JONAS; RIEDE ${ }^{72}$, 1980, CHANTAWIBOONCHAI et al. ${ }^{28}$, 1998 e TASHIRO et al. $\left.{ }^{169}, 2002\right)$.

Inserido no osso alveolar e amortecido pelo ligamento periodontal, o dente é composto por esmalte, dentina e cemento. $\mathrm{O}$ esmalte dentário, tecido mais duro do corpo, é formado gradualmente tendo seu desenvolvimento dividido em três estádios: formação inicial de esmalte mole, aposição de matriz protéica e maturação, conferindo dureza prévia à erupção dentária $\left(\mathrm{SATO}^{146}, 1996\right)$.

A dentina é o componente dentário mais abundante. Apresenta algumas proteínas ósseas em sua estrutura como a sialoproteína, a osteopontina e a osteocalcina (SILVA ${ }^{156}, 2003$ ). A dentinogênese consiste em um evento extracelular controlado por uma camada de odontoblastos maduros que secretam matriz protéica fibrilar de pré-dentina e sua subseqüente mineralização (BUTLER ${ }^{22}$, 1998, TAKANO et al. ${ }^{165}, 2000$, LEONORA; TJÄDERHANE; TIECHE ${ }^{95}, 2002$ e SILVA $\left.{ }^{156}, 2003\right)$.

O cemento é um tecido mineralizado avascular que recobre totalmente a raiz dentária. Está compreendido entre a dentina e o ligamento periodontal. É classificado nos tipos acelular ou celular dependendo ou não da presença de 
cementócitos, além disso, agrupa fibras intrínsecas e extrínsecas dependendo da presença de fibras colágenas formadas por cementoblastos ou fibroblastos, respectivamente. $\mathrm{O}$ cemento acelular encontra-se próximo à junção esmalte-cemento. O cemento celular apresenta cementócitos embutidos em matriz constituída por fibras colágenas intrínsecas que estão orientadas paralelamente à superfície radicular com curso padrão circundando a raiz. O cemento celular é encontrado em velhas lacunas de reabsorção. O cemento estratificado misto celular está localizado no ápice. É composto por camadas alternadas de cemento acelular com fibras extrínsecas e cemento celular e acelular com fibras intrínsecas, e é coberto por uma delicada camada de cemento acelular com fibras extrínsecas para união com o ligamento periodontal. O cemento estratificado funciona como remodelador da superfície radicular. O cemento acelular com fibras extrínsecas recobre de 40 a 70\% da superfície radicular e funciona exclusivamente como ancoragem para o ligamento periodontal (CHO; GARANT $\left.{ }^{31}, 2000\right)$. A composição do cemento é similar a do osso. É composto por $50 \%$ de hidroxiapatita e outros $50 \%$ de proteínas colagênicas e não-colagênicas, como sialoproteína do osso, osteocalcina, osteopontina (SAYGIN; GIANNOBILE; SOMERMAN ${ }^{147}, 2000$ ).

Durante a compressão do ligamento periodontal na movimentação dentária induzida as unidades osteorremodeladoras (BMUs) atuam sobre a superfície radicular. As condições fisiológicas podem influenciar o pré-cemento a perder a sua habilidade de proteção, favorecendo a diferenciação dos precursores clásticos para o estágio maduro. No entanto, a superfície radicular parece estar protegida por uma barreira não mineralizada ou parcialmente mineralizada - o cementóide. Sua presença implica em alta resistência à reabsorção radicular (BRUDVIK; RYGH ${ }^{21}$, 1993).

A resposta biológica à movimentação dentária induzida envolve alterações no osso circunjacente (HELLER; NANDA ${ }^{58}$, 1979). A formação óssea ocorre após secreção osteoblástica de matriz extracelular desmineralizada, osteóide, com posterior deposição de cristais de carbonato de apatita, resultando na formação de cristais (JEE; LI ${ }^{68}, 1990$, BUTLER ${ }^{22}, 1998$ e TAKANO et al. ${ }^{165}, 2000$ ). O 
aumento da formação óssea ocorre sem aumento numérico dos osteoblastos, indicando que cada osteoblasto deposita mais matriz (DUCY et al. ${ }^{35}, 1996$ ).

O osso é composto por osteoblastos e osteoclastos, em um processo contínuo de remodelação que é constituída pelas etapas de ativação, reabsorção, fase reversa e formação, todas controladas por mediadores químicos. Na formação óssea estão envolvidas a osteocalcina, fosfatase alcalina e extensões peptídicas do colágeno tipo I. Na reabsorção, a hidroxiprolina, cálcio urinário e a fosfatase ácido tartarato resistente (TRAP), enzima secretada pelos osteoclastos durante a fase ativa da reabsorção óssea, são identificadas na borda da membrana do osteoclasto e no espaço reabsortivo (JUNQUEIRA et al. ${ }^{73}, 2001$ ).

A matriz óssea é um complexo mineralizado depositado sobre um arcabouço de colágeno tipo I que contém número comparativamente menor de proteínas não colagênicas e glicoproteínas. As duas proteínas mais bem caracterizadas são a glicoproteína ${ }_{22} \mathrm{HS}$ e a osteocalcina e estão envolvidas no processo de mineralização (MALONE et al. ${ }^{104}, 1982$ ).

A osteocalcina, também chamada proteína Gla óssea (BGP) é a proteína da matriz óssea mais abundante e mais estudada (MALONE et al. ${ }^{104}, 1982$, CHENU et al. ${ }^{29}, 1994$ e DUCY et al. $\left.{ }^{35}, 1996\right)$. Sintetizada e secretada por osteoblastos maduros, incorpora-se a matriz extracelular e apresenta capacidade de ligar-se ao cálcio e hidroxiapatita, sendo um regulador negativo, ou seja, limitante para aposição e formação óssea (KOBAYASHI et al. $\left.{ }^{83}, 1998\right)$. O genoma do rato apresenta três genes relacionados à osteocalcina. O OG1 e OG2 são expressos em osso, enquanto que o gene relacionado à osteocalcina (OGR) é transcrito no rim (CHENU et al. ${ }^{29}$, 1994 e DUCY et al. $\left.{ }^{35}, 1996\right)$. Dentre suas funções pode-se destacar o recrutamento de clastos para o local da remodelação óssea, sendo um determinante na formação óssea (MUNDY et al. ${ }^{115}$, 1978, MALONE et al. ${ }^{104}$, 1982, CHENU et al. ${ }^{29}$, 1994, DUCY et al. ${ }^{35}, 1996$ e HASHIMOTO et al. $\left.{ }^{56}, 2001\right)$.

A fosfatase alcalina é o marcador de formação óssea e cementária mais amplamente utilizado (SAYGIN; GIANNOBILE; SOMERMAN 147, 2000 e JUNQUEIRA et al. $\left.{ }^{73}, 2001\right)$. As duas fosfatases ácidas demonstradas no tecido 
ósseo podem ser distinguidas pela sua sensibilidade ao tartarato. A enzima TRAP está presente nos osteoclastos e é reconhecida como uma característica específica sua e de seus precursores mononucleares (MARKS JUNIOR; GROLMAN ${ }^{107}$, 1987).

O osso alveolar e seus osteoclastos são semelhantes a todo o tecido ósseo. Ele apresenta alta taxa de turnover, sendo muito interessante para se estudar o metabolismo ósseo (VIGNERY; BARON ${ }^{187}, 1980$ e MARKS JUNIOR ${ }^{106}, 1983$ ). Muitos fatores de crescimento atuam no metabolismo ósseo, incluindo fator de crescimento insulina-like 1 e 2 (IGF-1 e IGF-2), fator de crescimento transformador beta 1 e $2\left(\mathrm{TGF}_{\beta}-1\right.$ e $\left.\mathrm{TGF}_{\beta}-2\right)$, fator de crescimento derivado de plaqueta (PDGF) e fator de crescimento fibroblástico (FGF). O IGF e o TGF são mitógenos mas modulam a síntese osteoblástica de colágeno tipo I e matriz. Outras citocinas induzem atividade reabsortiva, como interleucinas, fator de necrose tumoral (TNF), fator de crescimento epidérmico (EGF) e muitos fatores estimuladores de colônia (CSF). Possivelmente essas citocinas atuam sobre a reabsorção óssea por efeito direto nos osteoclastos maduros e em seus precursores, alterando os efeitos dos hormônios sobre as células ósseas e também sobre a função de outras células como osteoblastos e fibroblastos estromais, que direta ou indiretamente modulam a ação do clasto (FELIX; CECCHINI; FLEISCH ${ }^{40}, 1990$, WALLACH et al. ${ }^{190}, 1992$, GAO; FLAITZ; MACKENZIE ${ }^{48}$, 1996, UEMATSU; MOGI; DEGUCHI ${ }^{180}, 1996$ e OKUDA et al. $\left.{ }^{123}, 1998\right)$.

O sistema vascular e a circulação sangüínea têm sido investigados durante a movimentação dentária induzida por muitos estudiosos (BERNICK ${ }^{15}, 1960$, COHEN $^{32}, 1960$, BERNICK $^{16}, 1962$, KINDLOVÁ; MATĚNA ${ }^{80}, 1962$, CASTELLI ${ }^{26}, 1963$, CARRANZA et al. ${ }^{25}, 1966$, TURNER et al. ${ }^{178}, 1969$, WEEKS; SIMS ${ }^{192}$, 1986, LEW ${ }^{97}$, 1989, LEW; SIMS; LEPPARD ${ }^{98}$, 1989, SELLISETH; SELVIG ${ }^{151}$, 1994, VANDEVSKA-RADUNOVIC et al. ${ }^{183}$, 1994, IMAMURA; NAKATA; NAKASIMA ${ }^{65}, 2002$, TSUKADA et al. ${ }^{176}, 2000$, ATTAL et al. $\left.{ }^{8}, 2001\right)$. Os vasos sangüíneos constituem $11 \%$ do ligamento periodontal e sofrem alteração do fluxo sangüíneo devido às reações vasculares causadas por estímulos induzidos por forças experimentais (YAMAGUCHI; NANDA ${ }^{196}, 1992$ e TOMS; GANNON; CARATI $\left.{ }^{172}, 2000\right)$. As reações vasculares podem ser identificadas por análise morfológica do 
sistema vascular, medição do fluxo sangüíneo ou ambos. Para análise do fluxo sangüíneo pode-se utilizar o Doppler como técnica de escolha, uma vez que se trata de um método não-invasivo utilizado para avaliar o sistema microvascular íntegro (BAAB; ÖBERG; HOLLOWAY ${ }^{10}$, 1986, YAMAGUCHI; NANDA ${ }^{196}$, 1992 e ATTAL et al. ${ }^{8}, 2001$ ), ou outra técnica, descrita em 1986, que visualiza e quantifica o fluxo sangüíneo usando microesferas fluorescentes (TURNER et al. ${ }^{178}$, 1969, JOHNSON; HIGHISON ${ }^{71}$, 1985, BAAB; ÖBERG; HOLLOWAY ${ }^{10}$, 1986, HALE; VIVALDI; KLONER ${ }^{54}$, 1986, KVINNSLAND; HEYERAAS; ØFJORD ${ }^{89}, 1989$, VANDEVSKA-RADUNOVIC et al ${ }^{183}, 1994$ e ATTAL et al. ${ }^{8}, 2001$ ).

O ligamento periodontal apresenta um sistema microvascular composto por canais tissulares ultraestruturais que aumentam acentuadamente na presença da movimentação dentária (TURNER et al. ${ }^{178}$, 1969, WEEKS; SIMS ${ }^{192}, 1986$, FREEZER; SIMS 41, 1987, LEW 96, 1987, COOPER; SIMS ${ }^{34}$, 1989, CHINTAKANON; SIMS ${ }^{30}$, 1994, SELLISETH; SELVIG ${ }^{151}$, 1994, TANG; SIMS ${ }^{167}$, 1992, TANG et al. ${ }^{168}$, 1993, EL-AGROUDI; SELLISETH; SELVIG ${ }^{36}, 1998$ e ATTAL, et al. ${ }^{8}$ 2001). A microvascularização é composta por vasos de parede fina de calibre variado que se assemelham a capilares, além de apresentar estruturas suspensas que funcionam como amortecedores e nutrem as células que estão constantemente remodelando o osso alveolar e formando cemento (CASTELLI; DEMPSTER ${ }^{27}$, 1965, KINDLOVÁ ${ }^{79}$, 1965, WEEKS; SIMS ${ }^{192}$, 1986, LEW ${ }^{96}$, 1987, SELLISETH; SELVIG ${ }^{36}$, 1994, TOMS; GANNON; CARATI ${ }^{172}, 2000$ e TSUKADA et al. $\left.{ }^{176}, 2000\right)$. O mesmo ocorre durante a movimentação dentária induzida, pois a circulação sangüínea periodontal é modificada quando se aplica uma força sobre o dente, gerando alterações na amplitude da pulsação vascular (LEW; SIMS; LEPPARD ${ }^{98}, 1989$ e IMAMURA; NAKATA; NAKASIMA $\left.{ }^{65}, 2002\right)$. O aumento da vascularização ocorre devido ao aumento do diâmetro dos vasos e não pelo aumento de seu número.

O desenvolvimento do sistema vascular do rato é suprido por redes vasculares originadas na gengiva e no ligamento periodontal e pode ser assim descrito, de acordo com KINDLOVÁ; MATĚNA ${ }^{80}$, 1962, CARRANZA et al. ${ }^{25}$, 1966, SELLISETH; SELVIG ${ }^{36}, 1994$ e TSUKADA et al. $\left.{ }^{176}, 2000\right)$ : 
- Após o quinto dia de nascimento os capilares do órgão do esmalte formam uma delicada rede capilar.

- Após o $10^{\circ}$ dia, a vascularização do ligamento periodontal surge na porção cervical, em continuidade com o órgão do esmalte. Os vasos derivam da região basal do germe dentário, possuem trajeto paralelo ao longo eixo da raiz e conectam-se à rede vascular do órgão do esmalte. O limite entre os sistemas vasculares do órgão do esmalte e do ligamento periodontal são imprecisos neste estádio, mas não é difícil distingui-los entre si porque os vasos do órgão do esmalte são mais densos e entrelaçados que os vasos do ligamento periodontal, que correm principalmente paralelos ao longo eixo radicular.

- Após o $15^{\circ}$ dia o dente atinge o epitélio bucal e a formação radicular continua. Os vasos periodontais continuam alongando-se longitudinalmente e conectam-se com ramificações laterais formando uma rede vascular espessa. O limite entre os vasos sangüíneos do órgão do esmalte e do periodonto passa a ser mais preciso por causa das conexões laterais na região cervical e extremidade do órgão do esmalte, ou seja, na junção cemento-esmalte. Os vasos derivados do osso alveolar, via canais de Volkman, ramificam-se em direção ao ligamento periodontal e órgão do esmalte e contribuem para o desenvolvimento da vascularização periodontal. A região basal assemelha-se a múltiplas cestas de basquete com capilares sangüíneos formando laços (ATTAL et al. $\left.{ }^{8}, 2001\right)$.

- Após o $20^{\circ}$ dia a coroa irrompe e a raiz alonga-se. Neste estádio, os vasos do órgão do esmalte correspondem ao interior da rede vascular do epitélio gengival, devido ao irrompimento dentário.

- Após o $30^{\circ}$ dia o irrompimento está completo. A rede vascular periodontal está alongada e sua densidade é maior que a observada no $20^{\circ}$ dia, especialmente na porção radicular. Os capilares da região basal permanecem entrelaçados.

Os vasos sangüíneos do seguimento cervical do ligamento periodontal formam um plexo capilar denso e enovelado estendendo-se em direção à superfície 
gengival. Este plexo é suprido e drenado por quatro caminhos diferentes: 1 . Suprimento arteriolar e drenagem venular via ligamento periodontal; 2. Suprimento ligamentar e drenagem via gengiva inserida; 3. Suprimento gengival e drenagem ligamentar; ou 4. Suprimento e drenagem via vasos gengivais (KINDLOVÁ; MATĚNA ${ }^{80}$, 1962, GAENGLER; MERTE ${ }^{47}, 1983$ e SELLISETH; SELVIG ${ }^{151}$, 1994).

O seguimento médio do ligamento periodontal contém vasos de curso principalmente no sentido ocluso-apical, embora vasos transversos também estejam presentes. O plexo do seguimento médio apresenta arteríolas e vênulas cujo curso encerra na parede alveolar, e por capilares cujo curso encerra-se na superfície radicular. As arteríolas entram no ligamento periodontal através dos canais de Volkman. Os capilares desembocam nas vênulas que drenam para o ligamento periodontal (SELLISETH; SELVIG ${ }^{151}, 1994$ e ATTAL et al. ${ }^{8}, 2001$ ).

O seguimento apical do ligamento periodontal apresenta plexo microvascular que claramente é oriundo das porções média e cervical do ligamento periodontal. Este seguimento contém vênulas de diâmetro maior formando um plexo semelhante à rede de pesca, ou um capuz venular que se conecta com vasos oriundos da parte mais coronal do ligamento periodontal e com os vasos pulpares (KINDLOVÁ $^{79}$, 1965, SELLISETH; SELVIG ${ }^{151}, 1994$ e ATTAL et al. ${ }^{8}, 2001$ ).

Os principais vasos sangüíneos do ligamento periodontal do rato têm seu curso no sentido oclusoapical e exibem rica anastomose com vasos maiores através das perfurações da parede alveolar, além de não apresentarem sinais de válvulas (SELLISETH; SELVIG ${ }^{151}, 1994$ e ATTAL et al. ${ }^{8}, 2001$ ).

RYGH ${ }^{137}$, 1972 e SELLISETH; SELVIG ${ }^{151}, 1994$ afirmaram que a vascularização do ligamento periodontal de rato consiste, principalmente, de vênulas, não havendo arteríolas, e poucos capilares. Outros reconhecem a existência de arteríolas, capilares e vênulas no ligamento periodontal de rato, contudo o critério para classificação ou arranjo estrutural desses vasos não está claramente descrito. 
CARRANZA et al. ${ }^{25}, 1966$ relatou que o ligamento periodontal de ratos, camundongos, hamsters, gatos e cães apresentam formas similares de suprimento sangüíneo (GARFUNKEL; SCIAKY ${ }^{49}, 1971$ e ATTAL et al. ${ }^{8}$, 2001). Para SELLISETH; SELVIG ${ }^{151}$, 1994 o rato possui sistema sangüíneo arterial e venoso, embora haja evidências de rede dupla sangüínea, ou seja, separação dos sistemas venoso e arterial.

Alterações vasculares seqüenciais na área de compressão do ligamento periodontal estão bem documentadas. Estase, isquemia, diminuição gradual de capilares, presença de trombos, completa obliteração de vasos sangüíneos e degeneração vascular são algumas das alterações precoces descritas (CASTELLI; DEMPSTER $^{27}, 1965$, RYGH $^{137}, 1972$ e LEW $^{97}, 1989$ ).

Em contraste, descrições de alterações microvasculares na área de tensão do ligamento periodontal são escassas na literatura. Distensão e dilatação dos vasos sangüíneos na direção da tensão são relatadas (COOPER; SIMS ${ }^{34}$, 1989, LEW ${ }^{97}$, 1989 e TANG; SIMS ${ }^{167}, 1992$ e TANG et al. $\left.{ }^{168}, 1993\right)$.

A inervação do ligamento periodontal é feita por neurônios sensoriais primários oriundos do gânglio trigeminal. Projeções aferentes mecano-sensitivas periodontais são originárias no complexo nuclear sensorial do nervo trigêmio que enviam suas mensagens nervosas para o tálamo (ICHIKAWA; SUGIMOTO ${ }^{64}, 1997$, NAKAKURA-OHSHIMA ${ }^{118}$, 1998, TABATA; TAKAHASHI; HAYASHI ${ }^{163}$, 2001, ISHII; SOMA; TODA ${ }^{67}$, 2002, TABATA et al. ${ }^{164}$, 2002 e ZEREDO; TODA; SOMA ${ }^{204}$, 2002). Seus nervos geralmente estão associados aos vasos sangüíneos. São compostos por fibras sensoriais simpáticas que liberam neuropeptídeos vasoativos reguladores do fluxo sangüíneo local (VANDEVSKA-RADUNOVIC; KVINNSLAND; KVINNSLAND ${ }^{181}$, 1998).

O ligamento periodontal contém, pelo menos, dois tipos de receptores sensoriais: uma terminação nervosa livre nociceptora, e uma terminação mecanorreceptora especializada (MAEDA et al. ${ }^{103}$, 1989, KOBAYASHI et al. ${ }^{82}$, 1998, ATSUMI et al. ${ }^{4}$, 1999, ATSUMI et al. ${ }^{5}$, 1999, MURAMOTO; TAKANO; SOMA ${ }^{116}, 2000$ e WAKISAKA et al. ${ }^{188}, 2000$ ). A maioria das terminações nervosas 
livres do dente e periodonto contém o neuropeptídeo relacionado ao gene da calcitonina (CGRP) e à substância P. Ambos apresentam propriedades vasoativas, atividade quimiotática para neutrófilos, macrófagos e linfócitos $\mathrm{T}$, modulando a proliferação celular e influenciando a fagocitose (KVINNSLAND; KVINNSLAND ${ }^{88}, 1990$ e FRISTAD et al. $\left.{ }^{43}, 1995\right)$. Embora vários tipos de mecanorreceptores sejam citados por SCHROEDER ${ }^{150}, 1986$ apud ASAHITO et al. ${ }^{2}$, 1999, a terminação de Ruffini é o mecanorreceptor responsável pela detecção de extensão no ligamento periodontal e caracteriza-se por apresentar baixo limiar de excitação (KOBAYASHI et al. ${ }^{82}, 1998$, ATSUMI et al. ${ }^{6 \text { e } 7}, 2000$, WAKISAKA et al. ${ }^{188}, 2000$, HAYASHI et al. ${ }^{57}, 2000$ e YAMAMOTO et al. $\left.{ }^{197}, 2001\right)$. Seus corpos celulares encontram-se no núcleo mesencefálico trigeminal ou no gânglio trigeminal, e estão envolvidos na monitoração neural do desenvolvimento do germe dentário, irrompimento e oclusão do dente, além da movimentação dentária (BYERS; HOLLAND 23, 1977, ICHIKAWA; SUGIMOTO ${ }^{63}, 1998$ e MURAMOTO; TAKANO; SOMA ${ }^{116}, 2000$ ).

\subsection{Mediadores químicos da movimentação dentária}

Na movimentação dentária induzida o estresse mecânico evoca respostas bioquímicas aos diferentes tipos celulares periodontais via ativação de mediadores químicos e fatores de crescimento (ROBERTS; CHASE ${ }^{135}$, 1981, UEMATSU; MOGI; DEGUCHI ${ }^{180}, 1996$, NAGAI et al. ${ }^{117}, 1999$ e PERINETTI et al. ${ }^{128}, 2002$ ). As células envolvidas no processo de remodelação apresentam atividade enzimática que geram alterações na concentração de cálcio intracelular, e são controlados nos axônios terminais, ativando a transdução mecano-elétrica nos mecanorreceptores (JUNQUEIRA et al. ${ }^{73}, 2001$ ). Os estímulos mecânicos, as alterações bioelétricas, uma variedade de drogas e hormônios locais agem como primeiro mensageiro para promover a produção intracelular do segundo mensageiro como o $\mathrm{Ca}^{2+}$, a guanilil monofosfato (GMP) ou o AMPc (HIRUMA et al. ${ }^{61}$, 1998, NAGAI et al. ${ }^{117}, 1999$, SHIRAZI et al. ${ }^{154}, 2002$ e ZEREDO; TODA; SOMA ${ }^{204}$, 2002). Proteínas como a parvalbumina, calbidina e calretina controlam a homeostase do cálcio contra estímulos externos causados pelas forças oclusais constantes e remodelação periodontal das fibras colágenas (ROBERTS; CHASE ${ }^{135}$, 1981, ICHIKAWA; 
JACOBOWITZ; SUGIMOTO ${ }^{64}$, 1997, NAKAKURA-OHSHIMA ${ }^{118,}$ 1998, HIROSHIMA et al. ${ }^{60}, 1998$, JOHN et al. ${ }^{70}, 1999$ e ASAHITO et al. ${ }^{2}, 1999$ ).

A seqüência de eventos no periodonto que acompanha a movimentação dentária inclui remodelação óssea, contínuo rearranjo do ligamento periodontal e reabsorção radicular (MACAPANPAN; WEINMANN; BRODIE ${ }^{101}$, 1954, ZAKI; VAN HUYSEN ${ }^{202}, 1963$, AZUMA ${ }^{9}, 1970$, RYGH $^{138}, 1973 \mathrm{e}^{141}, 1977$, HELLER; $\left.\mathrm{NANDA}^{58}, 1979 \mathrm{e} \mathrm{KI}^{77}, 1990\right)$.

As prostaglandinas apresentam importante função na modulação da remodelação óssea induzida por estresse mecânico. A relação entre prostaglandina, reabsorção radicular e movimentação dentária foi examinada por muitos autores (YAMASAKI; MIURA; SUDA ${ }^{199}$, 1980, BRUDVIK; RYGH ${ }^{20}$, 1991, BOEKENOOGEN et al. ${ }^{17}$, 1996 e ZHOU; HUGHES; KING ${ }^{205}$, 1997). A seqüência de eventos inclui estresse mecânico provocado pela aplicação da força de movimentação, dano ou perturbação dos tecidos periodontais, síntese de prostaglandinas, acúmulo intracelular de AMPc e cálcio, modulação e ativação osteoclástica, reabsorção óssea e movimentação dentária (YAMASAKI; MIURA; SUDA $^{199}, 1980$, YAMASAKI ${ }^{198}, 1983$, BOEKENOOGEN et al. ${ }^{17}, 1996$ e ZHOU; HUGHES; KING ${ }^{205}$, 1997). A prostaglandina $E_{2}$ é extremamente atuante na formação do tecido ósseo, pois estimula a formação óssea lamelar, diminui a síntese de colágeno e aumenta o AMPc, acelerando o índice de movimentação dentária induzida (YAMASAKI ${ }^{198}$, 1983, WALLACH et al. ${ }^{190}$, 1992, BARON; TROSS; VIGNERY ${ }^{11}$, 1984, LEIKER et al. ${ }^{93}, 1995$, BOEKENOOGEN et al. ${ }^{17}, 1996$ e KOHNO et al. ${ }^{84}, 2003$ ).

O óxido nítrico é uma importante molécula sinalizadora óssea e está envolvida em muitos processos pato-fisiológicos, sendo produzida a partir da arginina por óxido nítrico sintase (NOS). Três formas podem ser isoladas. Duas delas são produzidas em resposta a estímulos químicos ou físicos por células endoteliais (ecNOS) e células nervosas (nNOS). A terceira forma é induzida (iNOS) por citocinas inflamatórias ou endotoxinas bacterianas (MARLETA ${ }^{108}$, 1993, HIKIJI et al. ${ }^{59}, 1997$, MANCINI et al. ${ }^{105}, 2000$, WAKISAKA et al. ${ }^{188}, 2000$ e BATISTA et al. $13,2002)$. Os osteoblastos produzem iNOS por indução de citocinas inflamatórias 
podendo inibir a atividade reabsortiva óssea do osteoclasto adjacente, sugerindo uma interferência entre osteoclastos e osteoblastos via óxido nítrico. No entanto, a função do óxido nítrico sobre o osteoblasto ainda é obscura (HIKIJI et al. $\left.{ }^{59}, 1997\right)$. Os melhores exemplos de reações biológicas controladas pelo óxido nítrico incluem vasodilatação e regulação da tonicidade vascular, inibição da agregação plaquetária, transmissão neural e citostase (MARLETA ${ }^{108}$, 1993), além de ser um ativador da guanilato ciclase (HIRUMA et al. ${ }^{61}$, 1998, NAGAI et al. ${ }^{117}$, 1999, BATISTA et al. ${ }^{13}$, 2002, SHIRAZI et al. ${ }^{154}, 2002$ e ZEREDO; TODA; SOMA ${ }^{204}, 2002$ ). O óxido nítrico é liberado por macrófagos e osteoclastos durante interações célula-célula. A elevação de seus níveis e a quantidade de GMP, o segundo mensageiro na remodelação óssea, participam do desencadeamento da reabsorção óssea com conseqüente aumento da taxa de movimentação dentária induzida.

Os fatores de crescimento são polipeptídeos que funcionam como potentes mediadores biológicos que estimulam várias atividades celulares (OKUDA et al. ${ }^{123}$, 1998).

O fator de crescimento endotélio vascular (VEGF) é o mais importante mediador para angiogênese, sendo detectado nos processos de desenvolvimento embrionário e em processos inflamatórios e reparadores. Ele promove angiogênese além de ser mitógeno específico para células vasculares endoteliais e estimular quimiotaxia para monócitos. Dentre as suas várias funções biológicas pode-se citar a permeabilidade vascular e a migração de monócitos humanos, além de ser usado para investigar atividade remodeladora vascular no ligamento periodontal (KAKU et al. ${ }^{75}$, 2001 e KOHNO et al. ${ }^{84}$, 2003).

As endotelinas regulam a reabsorção óssea por osteoclastos (HIRUMA et al. ${ }^{61}$, 1998). São sintetizadas pelas células vasculares endoteliais e são conhecidas por sua potente ação vasoconstrictora. Suas funções incluem controle da tonicidade do músculo vascular, influenciando na remodelação tecidual, estímulo celular, síntese de matriz e liberação de fatores de crescimento e moléculas de adesão (SIMS $\left.{ }^{160}, 2000\right)$. 
Os estímulos gerados em resposta ao estresse mecânico durante a movimentação dentária induzida mediam alterações teciduais que em conjunto com a ativação dos mediadores químicos resultam em nova condição homeostática do periodonto. São elas: hialinização, remodelação e reabsorção.

\subsection{Hialinização}

As alterações que acontecem no microambiente periodontal durante a movimentação dentária induzida influenciam a atividade e o metabolismo celular, resultando em um processo de necrose coagulativa asséptica, chamado processo de hialinização (HAMAYA et al. ${ }^{55}$, 2002). Observações microscópicas indicam que o ciclo e a patogenia das áreas hialinas constituem processo com muitos estádios onde diferentes reações teciduais ocorrem no microambiente durante a ativação da força experimental (BRUDVIK; RYGH ${ }^{21}$, 1993). Nesta área, há perda de estruturas fibrilares e o tecido necrótico hialinizado é removido por macrófagos perivasculares que invadem o tecido necrótico junto aos vasos sangüíneos (MACAPANPAN; WEINMANN; BRODIE ${ }^{101}, 1954$, RYGH ${ }^{137}, 1972,{ }^{138}, 1973,{ }^{139}, 1974 \mathrm{e}^{142}, 1986$, HELLER; NANDA ${ }^{58}, 1979$, WILLIAMS ${ }^{195}, 1984$ e BRUDVIK; RYGH ${ }^{21}, 1993$ ).

\subsection{Remodelação}

A remodelação do tecido conjuntivo mineralizado e não-mineralizado é essencial à movimentação dentária (SU et al. ${ }^{162}$, 1997). Forças mecânicas exercidas sobre o dente são transmitidas ao periodonto iniciando a atividade remodeladora que facilita a movimentação dentária. Isto é explicado pela teoria da pressão-tensão (SANDY; FARNDALE; MEIKLE ${ }^{145}$, 1993 e YOKOYA; SASAKI; SHIBASAKI $\left.{ }^{200}, 1997\right)$. A magnitude da força exercida durante a movimentação dentária induzida é um dos fatores importantes para o sucesso nos resultados (REITAN ${ }^{131}, 1964$, KHOUW; GOLDHABER ${ }^{76}$, 1970, TENSHIN et al. ${ }^{171}, 1995$ e ASHIZAWA; SAHARA $^{3}, 1998$ ), pois estimula a remodelação do ligamento periodontal (WALDO; ROTHBLATT ${ }^{189}, 1954$, OWAN ${ }^{124}, 1997$, KOBAYASHI et al. ${ }^{83}$, 1998) e processo 
alveolar (GIANELLY ${ }^{50}, 1969$, RYGH ${ }^{139}, 1974$ e YOKOYA; SASAKI; SHIBASAKI ${ }^{200}$, 1997). O complexo vascular periodontal tem função importante na remodelação tecidual durante a movimentação dentária induzida (EL-AGROUDI; SELLISETH; SELVIG ${ }^{36}, 1998$ e ATTAL et al. $\left.{ }^{8}, 2001\right)$. Teoricamente, a pressão exercida pela força sobre o ligamento não é suficiente para ocluir a rede vascular, no entanto desencadeia a liberação de neuropeptídeos vasoativos através de estímulos sensoriais nervosos (GIANELLY ${ }^{50}, 1969$, VANDEVSKA-RADUNOVIC; KVINNSLAND; KVINNSLAND ${ }^{182}, 1997$ e ATTAL et al. $\left.{ }^{8}, 2001\right)$.

A proliferação celular e a migração dos ligamentos foram estudadas em condições fisiológicas (McCULLOCH; MELCHER 109, 110 e 111, 1983), durante osteogênese induzida por movimentação dentária (ROBERTS; CHASE ${ }^{135}$, 1981 e MABUCHI; MATSUZAKA; SHIMONO ${ }^{100}$, 2002). A força induzida gera um aumento da proliferação e diferenciação de osteoblastos no ligamento periodontal (PERINETTI et al. ${ }^{128}, 2002$ ).

Alguns autores estudaram a reconstrução do osso alveolar e o rearranjo do ligamento periodontal. Eles visualizaram aumento da síntese de colágeno, remodelação e rearranjo das fibras periodontais (MACAPANPAN; WEINMANN; BRODIE ${ }^{101}, 1954$, AZUMA ${ }^{9}, 1970$ e TENSHIN et al. $\left.{ }^{171}, 1995\right)$.

A remodelação tecidual do ligamento periodontal relaciona-se com seu mecanismo modulador homeostático. Ocorre controle da população celular, manutenção do espaço periodontal e reparação de tecidos. Uma hipótese para regulação deste mecanismo é a proliferação e morte celular participando para manter a homeostase no ligamento periodontal durante a movimentação dentária (LEKIC et al. ${ }^{94}, 1997$ e MABUCHI; MATSUZAKA; SHIMONO ${ }^{100}$, 2002).

A remodelação e o rearranjo do tecido supra-alveolar são indispensáveis para a estabilização dos dentes após a movimentação dentária. As fibras transeptais necessitam de longo período de retenção para concluir seu rearranjo e remodelação (TENSHIN et al. $\left.{ }^{171}, 1995\right)$. O ligamento periodontal apresenta importante função na remodelação óssea da interface osso alveolar-ligamento periodontal durante a movimentação dentária induzida (KYOMEN; TANNE $\left.{ }^{90}, 1997\right)$. 
Para explicar como o ligamento periodontal é remodelado durante a movimentação dentária fisiológica introduziu-se o conceito da reabsorção e síntese colagênica que permite a movimentação. 1. Atividade osteogênica progressiva e cementogênica em menor grau demonstrando uma função ativa de encurtamento das fibras tensionadas e uma reconexão de novas fibras durante a movimentação dentária; 2. Distensão de fibras colágenas onduladas e reorientação morfológica de suas fibras permitem movimentação; 3. A existência de outro tipo de fibra permite que os feixes de fibras deslizem entre si com subseqüente reorientação na nova posição (TEN CATE $\left.{ }^{170}, 1976\right)$. A remodelação ocorre através da exposição à colagenase, com conseqüente clivagem do colágeno em peptídeos, que são reconhecidos e fagocitados pelos fibroblastos (SCHELLENS; EVERTS; BEERTSEN ${ }^{149}, 1982$ e TALIC et al. $\left.{ }^{166}, 2003\right)$.

As fibras nervosas são rearranjadas rapidamente após a movimentação dentária (KOBAYASHI et al. ${ }^{82}, 1998$ e WAKISAKA et al. ${ }^{188}$, 2000). Os nervos periodontais apresentam alto potencial para plasticidade neural, adaptando-se às modificações ambientais provocadas pela indução de força durante a movimentação dentária (KVINNSLAND; KVINNSLAND ${ }^{88}$, 1990, MAEDA; BYERS ${ }^{102}$, 1996, KOBAYASHI et al. ${ }^{82}$, 1998, YOUN et al. ${ }^{201}$, 1998, ATSUMI et al. ${ }^{5}, 1999$ e YAMAMOTO et al. $\left.{ }^{197}, 2001\right)$.

As células de Schwann apresentam importante função durante a regeneração dos nervos periféricos e estão associadas às terminações de Ruffini e para adaptarem-se ao ligamento modificado requerem plasticidade mediada pela proteína associada ao crescimento (GAP-43). Também conhecida como B-50, pp-43, F1 e neuromodulina, é uma fosfoproteína de membrana, específica dos neurônios, que modula a regulação do crescimento do axônio e as sinapses (YOUN et al. ${ }^{201}$, 1998 e WAKISAKA et al. ${ }^{188}$, 2000). Há contínua remodelação das terminações nervosas associada com dinâmica reconstrução das fibras periodontais (MAEDA et al. ${ }^{103}$, 1989, ICHIKAWA; SUGIMOTO ${ }^{64}$, 1997, KOBAYASHI et al. ${ }^{82}$, 1998, NAKAKURA-OHSHIMA ${ }^{118}, 1998$, ATSUMI et al. ${ }^{5}, 1999$, ATSUMI et al. ${ }^{6}$ e 7 , 2000, HAYASHI et al. ${ }^{57}, 2000$ e MURAMOTO; TAKANO; SOMA $\left.{ }^{116}, 2000\right)$. 
Durante a movimentação dentária induzida o ligamento periodontal é temporariamente perturbado, podendo causar reabsorção cementária (LASFARGUES; SAFFAR ${ }^{92}$, 1993). A remodelação do cemento tem sido associada com a remodelação do ligamento periodontal e do osso alveolar (KIMURA et al. ${ }^{78}$, 2003). O ligamento adapta-se rapidamente ao turnover ósseo enquanto são depositadas camadas adicionais de cemento de acordo com a orientação das fibras de Sharpey (REITAN ${ }^{132}, 1974$ e LASFARGUES; SAFFAR ${ }^{92}$, 1993). A sialoproteína óssea, a osteopontina e o colágeno tipo I são responsáveis pela regeneração do cemento (SAYGIN; GIANNOBILE; SOMERMAN ${ }^{147}, 2000$ ).

Os vertebrados remodelam osso continuamente (DUCY et al. $\left.{ }^{35}, 1996\right)$. O componente osteogênico do ligamento periodontal responde à força aplicada durante a movimentação dentária com aumento da proliferação osteoblástica (MACAPANPAN; WEINMANN; BRODIE ${ }^{101}$, 1954 e ROBERTS; CHASE ${ }^{135}$, 1981). Embora haja numerosos estudos histomorfométricos sobre remodelação óssea (LÓPEZ OTERO et al. ${ }^{99}$, 1973, YAMASAKI; MIURA; SUDA ${ }^{199}$, 1980 e KING et al. ${ }^{81}, 1991$ ), poucas informações estão à disposição sobre o volume de osso alveolar neoformado durante a movimentação dentária (HELLER; NANDA ${ }^{58}, 1979$ e ASHIZAWA; SAHARA $\left.{ }^{3}, 1998\right)$. O osso alveolar adapta-se à deformação da parede óssea frente ao movimento radicular (lado de remodelação) por um equilíbrio negativo de ciclos de reabsorção-formação. No lado oposto (lado de modelação) há contínua formação óssea compensatória (VIGNERY; BARON ${ }^{187}, 1980$ e LASFARGUES; SAFFAR $\left.{ }^{92}, 1993\right)$.

O estresse mecânico é um importante fator regulador e um determinante da morfologia óssea desde estádios precoces (PAVLIN et al. ${ }^{125}, 2000$ ). Está bem descrito na literatura que reabsorção e remodelação óssea são controladas por osteoclastos e osteoblastos, respectivamente, formando temporariamente BMUs (JUNQUEIRA et al. ${ }^{73}, 2001$ e KAKU et al. ${ }^{75}$,2001). A remodelação óssea é iniciada com a conversão de uma área inativa em um sítio de remodelação, constituindo a fase de ativação que envolve a proliferação de vasos sangüíneos que são necessários para conduzir as células da reabsorção. $O$ osteoclasto promove a formação de cavidade e é reposicionado em outro futuro local a ser desgastado. Enquanto isso o 
osteoblasto é recrutado para preenchimento da cavidade deixada. Estes eventos ocorrem concomitantemente em uma BMU e a formação ocorre enquanto a reabsorção vai avançando. $\mathrm{O}$ intervalo entre o fim da reabsorção e o começo da formação óssea é a fase reversa, quando o osso velho é recoberto por uma fina camada de substância composta por colágeno e matriz rica em aminoglicosídeos, glicoproteínas e ácido fosfático para os osteoclastos se fixarem. Novos osteoblastos se juntam apenas aos sítios onde os osteoclastos recentemente atuaram, constituindo o fenômeno chamado de acoplamento (JUNQUEIRA et al. ${ }^{73}, 2001$ ).

A chegada de osteoblastos no lugar certo, no tempo certo e em quantidade suficiente é resultado da produção simultânea de osteoblastos e osteoclastos na medula óssea e da liberação de substâncias osteotrópicas do osso reabsorvido. Durante os seis a nove meses de duração de uma BMU, a curta vida dos osteoclastos e osteoblastos requer o recompletamento contínuo, mantendo sempre a mesma relação espacial entre as diversas BMUs (JUNQUEIRA et al. ${ }^{73}, 2001$ ).

A remodelação óssea é resultante de uma série de eventos coordenados entre si que inclui reabsorção e formação óssea (TEN CATE ${ }^{170}$, 1976). Esse padrão de organização é modulado de acordo com a atuação dos osteoblastos, osteócitos e osteoclastos por intermédio de comunicação intercelular. Durante a comunicação intercelular pode ocorrer secreção de fatores solúveis, em resposta a sinais extracelulares mecânicos ou hormonais. O contato pode ser direto célula-célula, através de molécula de adesão, ou por acoplamento metabólico e elétrico através das junções gap (SU et al. ${ }^{162}, 1997$ e TRAN VAN; VIGNERY; BARON ${ }^{174}, 1982$ ).

A remodelação óssea durante a movimentação dentária induzida é descrita como um contínuo processo de equilíbrio caracterizado por reabsorção óssea no lado de compressão e deposição no lado tensão (RYGH ${ }^{137}, 1972 \mathrm{e}^{140}, 1976$, KURIHARA; ENLOW ${ }^{87}, 1980$ e PERINETTI et al. ${ }^{128}$, 2002). A remodelação óssea durante a movimentação dentária induzida é resultante da aplicação de força mecânica sobre o dente que gera aumento de esforço no ligamento periodontal por geração de sinais elétricos que desencadeiam proliferação e diferenciação celular promovendo a remodelação óssea iniciando a resposta remodeladora óssea por 
alteração intracelular do AMPc (SMITH; ROBERTS ${ }^{161}, 1980$ e YOKOYA; SASAKI; SHIBASAKI ${ }^{200}$, 1997).

A remodelação do trabeculado ósseo do rato segue a mesma seqüência que a descrita para os humanos (VIGNERY; BARON ${ }^{187}$, 1980, TRAN VAN; VIGNERY; BARON ${ }^{174}$, 1982, BARON; TROSS; VIGNERY ${ }^{11}, 1984$ e LASFARGUES; SAFFAR ${ }^{92}$, 1993). Seu ligamento periodontal apresenta vantagens relacionadas ao estudo da cinética celular para estimular remodelação óssea. O osso alveolar adjacente pode ser induzido a formar ou reabsorver osso por causa do padrão de movimentação fisiológica que os molares apresentam (ROBERTS; CHASE $^{134}, 1974$ e ROBERTS; CHASE ${ }^{135}, 1981$ ).

O osteoclasto é o efetor da reabsorção óssea (GOLDIE; KING ${ }^{51}, 1984$, ALVAREZ et al. ${ }^{1}, 1992$, CHENU et al. ${ }^{29}, 1994$ e KIMURA et al. $\left.{ }^{78}, 2003\right)$. O mecanismo exato pelo qual os osteoclastos migram para o ligamento periodontal após a aplicação de força ainda é, em parte, desconhecido (MARKS JUNIOR ${ }^{106}$, 1983 e TSAY; CHEN; OYEN ${ }^{175}$, 1999). No entanto, sabe-se que determinantes moleculares modulam a atividade osteoclástica (DUCY et al. $\left.{ }^{35}, 1996\right)$. Essas células são amplas e apresentam bordas irregulares no local da reabsorção, áreas claras, abundantes mitocôndrias, numerosas projeções citoplasmáticas, retículo endoplasmático rugoso disperso e atividade de TRAP (MARKS JUNIOR ${ }^{106}, 1983$, GRIGORIADIS et al. ${ }^{52}$, 1994 e KIMURA et al. ${ }^{78}$, 2003).

\subsection{Reabsorção}

A reabsorção é um processo que envolve a proliferação e desenvolvimento dos osteoclastos, migração para o local de reabsorção, adesão e polarização à matriz óssea. Quando os osteoclastos polarizam-se cria-se uma adesão entre sua membrana e a superfície óssea, isolando a área irregular onde a reabsorção ocorrerá (CHENU et al. $\left.{ }^{29}, 1994\right)$.

A reabsorção óssea é um componente essencial da modelação e remodelação tecidual, ocorrendo em diferentes circunstâncias, fisiológicas ou 
patológicas, como remodelação óssea, irrompimento dentário, movimentação dentária fisiológica e induzida (UBIOS et al. ${ }^{179}, 1993$ e SALO et al. ${ }^{143}$, 1997). A reabsorção é induzida por um complexo processo que inicia com recrutamento de precursores de osteoclastos aos futuros locais a serem reabsorvidos, onde eles tornam-se maduros e aderem à matriz. Isto ocorre acompanhado por uma organizada área de vedação com bordas irregulares (KOBAYASHI et al. $\left.{ }^{83}, 1998\right)$.

A reabsorção dentária foi relatada em humanos e animais acompanhando a movimentação dentária induzida. Alguns fatores influenciam a resistência inata da superfície radicular, como superfície imatura do cemento, maturação do colágeno, concentração de fluoretos e suprimento sangüíneo relativamente pobre para o cemento (WILLIAMS ${ }^{195}$, 1984, WESSELINK; BEERTSEN; EVERTS ${ }^{194}, 1986$ e NAKANE; KAMEYAMA $\left.{ }^{119}, 1987\right)$.

A associação entre força aplicada e reabsorção óssea sugere que o tipo de reabsorção esteja relacionada à integridade do ligamento periodontal, que por sua vez depende da integridade vascular (MOYERS; BAUER ${ }^{114}$, 1950, REITAN ${ }^{132}, 1974$, GIANELLY ${ }^{50}$, 1969, YAMAGUCHI; NANDA ${ }^{196}, 1992$ e YOKOYA; SASAKI; SHIBASAKI $\left.{ }^{200}, 1997\right)$.

Schwarzkopf em 1887 foi o primeiro a descrever a reabsorção radicular (REITAN ${ }^{132}$, 1974). Ketcham iniciou seus estudos sobre a reabsorção radicular em 1927 e desde então muitos investigadores têm se preocupado com sua etiopatogenia (REITAN ${ }^{132}, 1974$, GOLDIE; KING ${ }^{51}, 1984$, GRIMM ${ }^{53}, 1972$ e KIMURA et al. ${ }^{78}$, 2003). BRUDVIK, RYGH ${ }^{21}, 1993$ investigaram as alterações iniciais que ocorrem na superfície radicular na periferia das áreas de hialinização durante o prelúdio e subseqüente processo de reabsorção do cemento mineralizado.

Reabsorção e encurtamento radicular podem ser considerados como conseqüência de movimentação dentária induzida (RYGH ${ }^{141}, 1977$ e MELSEN ${ }^{112}$, 2001). A força exercida durante a movimentação dentária induz reabsorção óssea osteoclástica na área de compressão e aposição óssea na área de tensão (RYGH ${ }^{137}$, $1972,{ }^{138}, 1973$ e NAGAI et al. $\left.{ }^{117}, 1999\right)$. 
Em animais experimentais a reabsorção radicular pode ser induzida por movimentação dentária (WESSELINK; BEERTSEN; EVERTS ${ }^{194}$, 1986). Ocorre nas imediações da área de hialinização em meio a rede ricamente vascularizada, sugerindo um possível envolvimento da atividade celular associada à remoção de tecido necrótico na zona hialina, incluindo a camada cementóide (BRUDVIK; $\left.\mathrm{RYGH}^{21}, 1993\right)$.

Inicialmente observam-se alterações delicadas que ocorrem na periferia do tecido necrótico principal. A reabsorção acontece de 4 a 6 dias após essas alterações, acometendo as partes da superfície radicular que estão em contato direto com o tecido. A reabsorção radicular não se inicia sob as partes centrais das áreas hialinas, mas sim em sua periferia, onde as células viáveis ainda existem (BRUDVIK; RYGH ${ }^{21}, 1993$ ).

Vários autores estudaram o comportamento do ligamento periodontal após a ação de forças induzidas (MACAPANPAN; WEINMANN; BRODIE ${ }^{101}$, 1954, WALDO; ROTHBLATT ${ }^{189}$, 1954, ZAKI; VAN HUYSEN ${ }^{202}$, 1963, AZUMA 9, 1970, REITAN ${ }^{132}$, 1974, RYGH ${ }^{140}$, 1976, HELLER; NANDA ${ }^{58}$, 1979, MIDGETT; SHAYE; FRUGE ${ }^{113}, 1981$, ROBERTS; CHASE ${ }^{135}$, 1981, TRAN VAN; VIGNERY; BARON ${ }^{174}, 1982$, WILLIAMS ${ }^{195}, 1984$, PENDER; HEANEY ${ }^{126}, 1995$, DUCY et al. ${ }^{35}$, 1996, ASHIZAWA; SAHARA ${ }^{3}$, 1998, NAGAI et al. ${ }^{117}$, 1999, VERNA; ZAFFE; SICILIANI ${ }^{186}$, 1999, TOMS; GANNON; CARATI ${ }^{172}, 2000$, HASHIMOTO et al. ${ }^{56}, 2001$, KAKU et al. ${ }^{75}$, 2001, HAMAYA et al. ${ }^{55}, 2002$, SHIRAZI et al. ${ }^{154}, 2002$, KOHNO et al. ${ }^{84}, 2003$, TALIC et al. ${ }^{166}, 2003$ e VERNA; MELSEN $\left.^{185}, 2003\right)$.

BRUDVIK, RYGH ${ }^{21}, 1993$ mesializaram o primeiro molar por 3 e 5 dias sem reativação durante o experimento. $\mathrm{O}$ grupo dele foi constituído por 21 animais, com três animais em cada grupo. O lado oposto foi o controle com períodos experimentais de 6 e 12 horas, 1, 2, 3, 4 e 5 dias.

A relação entre movimentação dentária e alterações no periodonto foi analisada em estudo que usava forças ortodônticas suaves (inferior a 10 gf) e verificou-se que a compressão do ligamento periodontal, a existência de tecido 
hialinizado e a reabsorção óssea no lado de compressão regulam a taxa de movimentação dentária, concluindo que forças ortodônticas suaves sem inclinação por atrição foram constantes ou variavam por períodos longos (KOHNO et al. ${ }^{84}$, 2002).

VASCONCELOS ${ }^{184}, 1996$ estudou a ação de forças excessivas sobre o periodonto de sustentação durante sete dias e verificou que as alterações celulares e teciduais observadas caracterizavam um quadro de reabsorção óssea à distância, ou mais propriamente, periférica à área periodontal submetida à pressão.

Embora existam vários estudos sobre a fase inicial da movimentação dentária induzida em ratos, poucos trabalham descrevem minuciosamente as alterações morfológicas ocorridas no periodonto de sustentação para que possa ser estabelecido um dia ideal de observação. 


\section{PROPOSIÇÃO}

Visando estabelecer um tempo ideal para observação das alterações ocorridas desde o início da movimentação dentária induzida experimental, traçou-se um perfil morfológico tecidual diário, desde as fases iniciais do movimento dentário induzido em ratos, utilizando-se como controle os dentes não movimentados do lado oposto, considerando-se:

- Os aspectos de normalidade (lado controle) e os fenômenos microscópicos observados durante o movimento dentário induzido, desde as fases iniciais, descrevendo-os minuciosamente;

- A intensidade e extensão da reabsorção óssea;

- A intensidade e extensão da reabsorção dentária. 
3 MATERIAL E MÉTODOS 


\section{MATERIAL E MÉTODOS}

\subsection{Seleção da Amostra}

A amostra foi constituída por 21 ratos machos da linhagem Wistar (Rattus norvegicus, albinus) com 90 a 120 dias, pensando aproximadamente 315 gramas provenientes do biotério da Faculdade de Odontologia de Bauru da Universidade de São Paulo.

Durante o período experimental os animais permaneceram no biotério da disciplina de Patologia Bucal da Faculdade de Odontologia de Bauru da Universidade de São Paulo. Foram acondicionados em gaiolas plásticas forradas com papel branco e divididos em sete grupos de três animais cada. A iluminação foi natural e a temperatura ambiente. Receberam alimentação sólida ${ }^{*}$, na forma de ração triturada, e água sem restrições.

\subsection{Distribuição da Amostra}

Os animais foram distribuídos aleatoriamente em sete grupos experimentais, com três espécimes cada. O grupo de dentes estudado foi composto pelos primeiros molares superiores com o lado esquerdo representando o lado experimental (ME), e o direito, o controle (MC).

- Grupo I - Três animais mortos com um dia de movimentação dentária induzida;

- Grupo II - Três animais com dois dias de movimentação dentária induzida;

- Grupo III - Três animais com três dias de movimentação dentária induzida;

\footnotetext{
* Marca comercial - Labina Purina.
} 
- Grupo IV - Três animais com quatro dias de movimentação dentária induzida;

- Grupo V - Três animais com cinco dias de movimentação dentária induzida;

- Grupo VI - Três animais com seis dias de movimentação dentária induzida;

- Grupo VII - Três animais com sete dias de movimentação dentária induzida.

\subsection{Preparo do Aparelho}

O aparelho foi construído a partir de modelo proposto por HELLER; NANDA ${ }^{58}$ (Figura 1) e consiste em uma mola de aço inox fechada de $4 \mathrm{~mm}$ de comprimento com fio de 0,022 polegada; fio de amarrilho de aço inox com 0,00012 polegada para fixação da mola no primeiro molar superior; fio de amarrilho de aço inox com 0,008 polegada para fixação da mola no incisivo superior.

\subsection{Anestesia dos Animais}

Para o procedimento de instalação do aparelho ortodôntico os animais foram anestesiados com Dopalen e Anasedan, na dosagem de $30 \mathrm{mg} / \mathrm{kg}$ de peso corporal. A solução anestésica foi injetada por via intraperitoneal. 

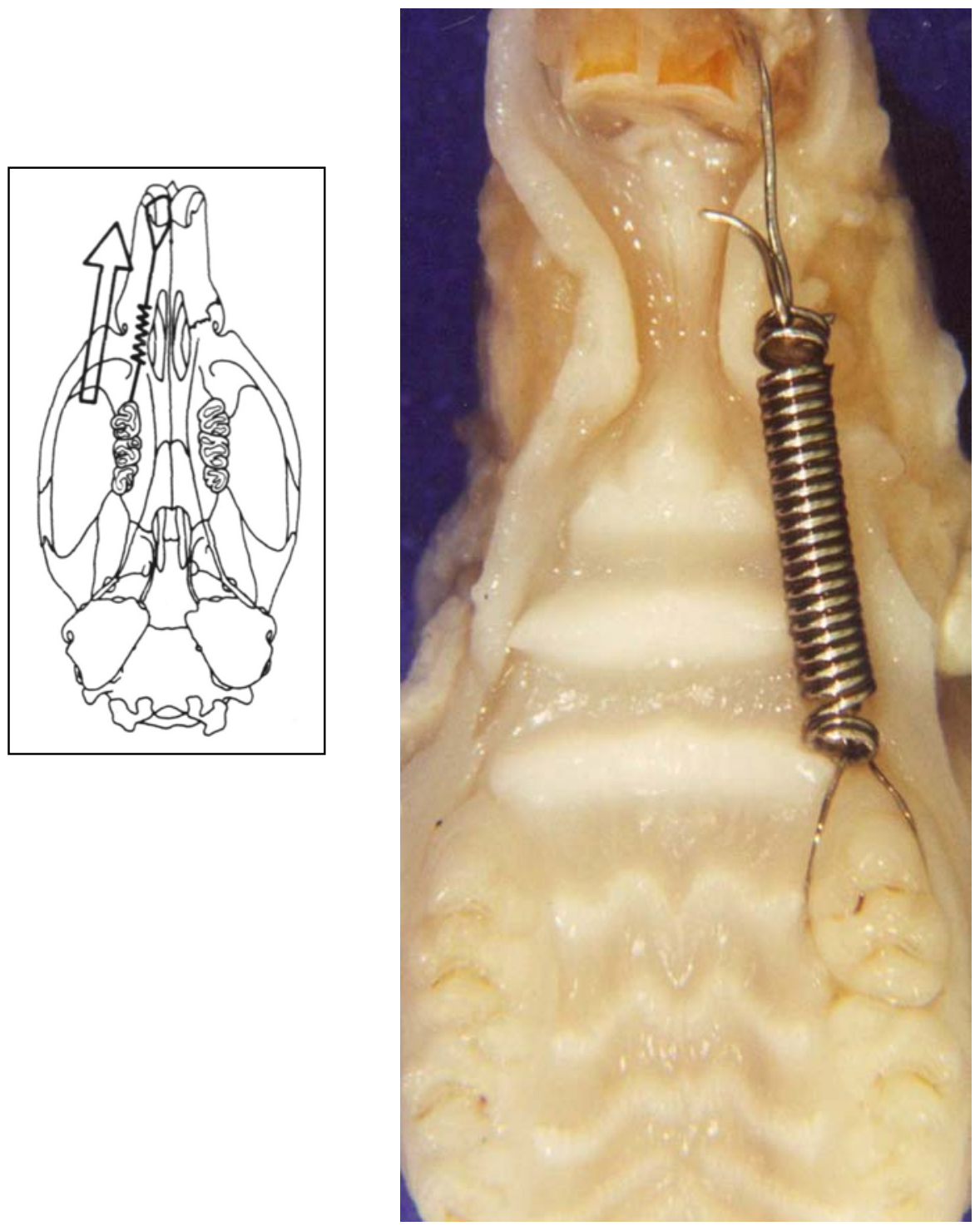

Figura 01 - Desenho esquemático de aparelho proposto por HELLER; NANDA ${ }^{58}$ em 1979, à esquerda. Foto do aparelho posicionado em rato ligando o incisivo e o primeiro molar esquerdo superior, à direita

\subsection{Instalação e Ativação dos Aparelhos}

Após posicionar os animais na mesa operatória, própria para contenção e abertura da boca do animal, as molas ortodônticas foram unidas ao primeiro molar superior esquerdo e ao incisivo superior do mesmo lado, por meio de fio de amarrilho. A ancoragem da mola nos dentes foi feita por intermédio de fios de 
amarrilho passados na região interproximal. No caso do incisivo, foi criado um reforço mecânico, com broca troncocônica, constituído por pequeno sulco no terço cervical mesial e distal da coroa dentária para encaixe do fio, em seguida colocava-se resina composta ortodôntica para cobrir a amarração. Uma força inicial de 50 a $75 \mathrm{~g}$, mensurada por dinamômetro, foi obtida estirando a mola em $2 \mathrm{~mm}$, aproximadamente.

Após a ativação inicial o aparelho não recebeu nenhuma ativação adicional durante o período experimental, no entanto seu posicionamento foi conferido diariamente. A movimentação dentária ocorreu no molar superior no sentido mesial, e no incisivo, no sentido palatino.

Os molares superiores do lado direito foram utilizados como controle para padronização da observação dos fenômenos biológicos do movimento dentário induzido.

\subsection{Morte dos animais, Obtenção e Preparo dos Espécimes}

Ao término dos períodos experimentais os animais foram mortos por injeção de dose excessiva anestésica por via peritoneal, e em seguida decapitados. Suas cabeças foram dissecadas removendo-se os componentes de tecido mole. As maxilas foram colocadas em solução tamponada de formol 10\% para fixação, por um período de 48 horas. Após a mesma os espécimes foram colocados em solução desmineralizadora de etilenodiaminotetracetatodissódico a 5\% (EDTA), tamponado em pH 5,0 com fosfato de sódio por tempo suficiente para permitir o processamento histotécnico.

\subsection{Processamento Histotécnico das Peças Cirúrgicas}

Decorridos aproximadamente três meses de desmineralização os espécimes foram processados no Laboratório de Anatomia Patológica da FOB/ USP. Os cortes foram realizados em plano mesialmente ao primeiro molar para separar as porções anterior e posterior da maxila. Em seguida, realizou-se corte longitudinal para separar os lados direito e esquerdo da maxila posterior. Após conferir superfície de corte aos espécimes, os mesmo foram emblocados em parafina e cortados em 
micrótomo com $5 \mu \mathrm{m}$ de espessura que foram corados pela técnica de coloração de rotina usando hematoxilina e eosina.

\subsection{Análise Microscópica}

Ao término dos procedimentos laboratoriais, os cortes teciduais obtidos foram observados em microscópio um Nikon binocular. As áreas analisadas corresponderam ao periodonto de inserção dos primeiros molares superiores movimentados e do lado controle, de todos os grupos experimentais. Para análise foram selecionadas as áreas correspondentes à compressão e à tensão da raiz mesial do primeiro molar superior.

\subsubsection{Fenômenos Analisados}

- Caracterização dos tipos celulares predominantes nos diferentes períodos experimentais;

- Alterações morfológicas, localização e distribuição das células do ligamento periodontal;

- Áreas hialinas no ligamento periodontal, morfologia e disposição das fibras colágenas periodontais;

- Caracterização das áreas hialinas: pequenas, médias e grandes;

- Forma, diâmetro e distribuição dos vasos sangüíneos periodontais;

- Alterações circulatórias: tipos de infiltrado inflamatório, congestão, exsudato, hemorragia e trombose;

- Regularidade das superfícies óssea e cementária e presença de osteóide ou cementóide;

- Reabsorção e aposição nas superfícies óssea e cementária. 
Os resultados foram registrados em tabela similar a da figura 2 .

\subsection{Análise Estatística}

Este estudo é de caráter qualitativo descritivo, não sendo necessária a aplicação de teste estatístico. 


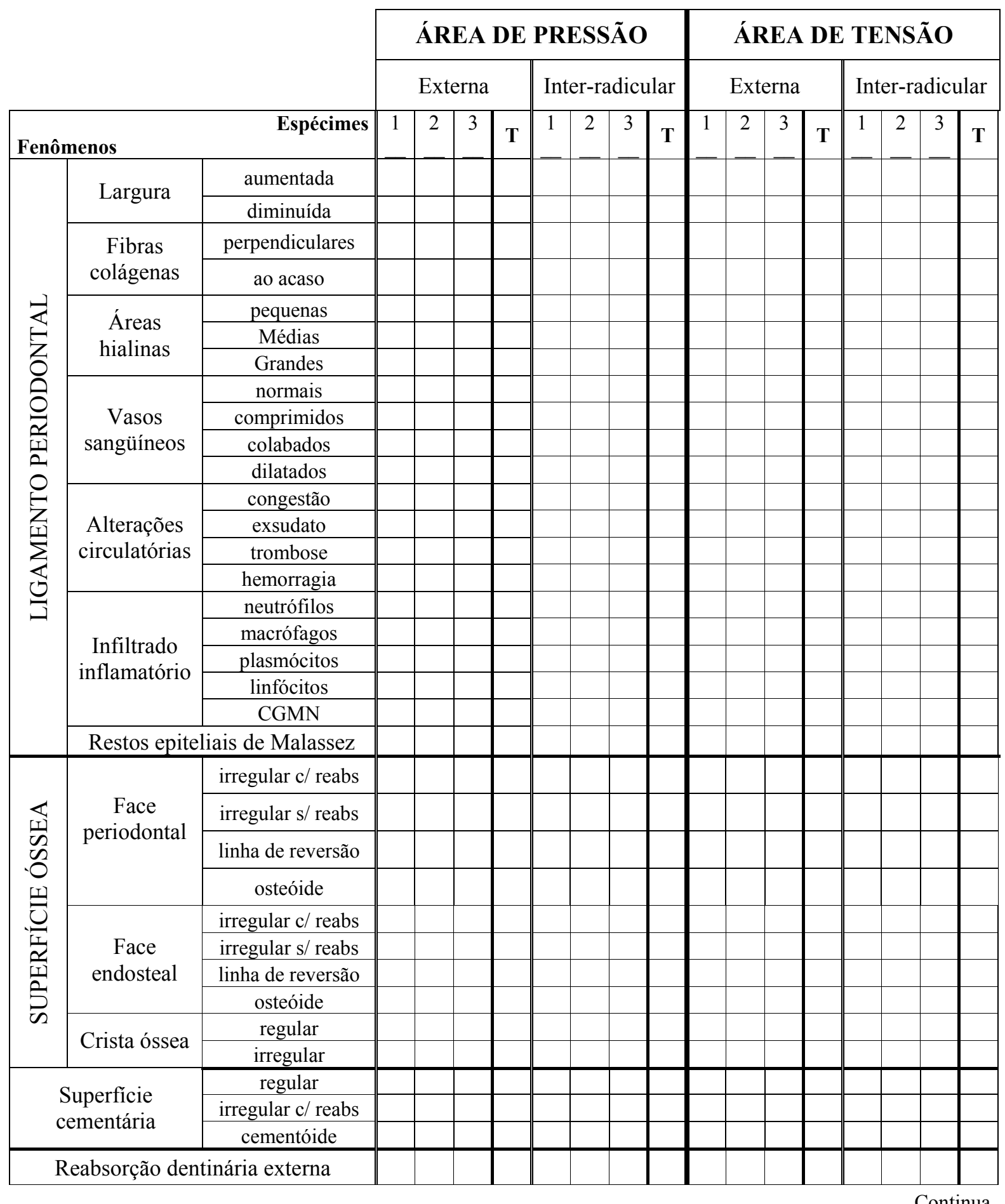


Continuação Figura 2

\begin{tabular}{|c|c|c|c|c|c|c|c|c|c|c|c|c|c|c|c|c|c|c|}
\hline \multicolumn{3}{|c|}{ Fenômenos } & 1 & 2 & 3 & $\mathbf{T}$ & 1 & 2 & 3 & $\mathbf{T}$ & 1 & 2 & 3 & $\mathbf{T}$ & 1 & 2 & 3 & $\mathbf{T}$ \\
\hline \multirow{5}{*}{$\begin{array}{l}0 \\
0 \\
0 \\
\frac{0}{0} \\
0 \\
0 \\
0 \\
0\end{array}$} & \multirow{3}{*}{ Núcleo } & mitótico & & & & & & & & & & & & & & & & \\
\hline & & picnótico & & & & & & & & & & & & & & & & \\
\hline & & cariorrexe & & & & & & & & & & & & & & & & \\
\hline & \multirow{2}{*}{$\begin{array}{c}\text { Quanto à } \\
\text { disposição }\end{array}$} & fasciculado & & & & & & & & & & & & & & & & \\
\hline & & ao acaso & & & & & & & & & & & & & & & & \\
\hline \multirow{7}{*}{$\begin{array}{l}0 \\
0 \\
\frac{0}{0} \\
\frac{\pi}{0} \\
0 \\
0 \\
\frac{d}{0} \\
0\end{array}$} & \multirow{3}{*}{ Núcleo } & mitótico & & & & & & & & & & & & & & & & \\
\hline & & picnótico & & & & & & & & & & & & & & & & \\
\hline & & cariorrexe & & & & & & & & & & & & & & & & \\
\hline & \multirow{2}{*}{$\begin{array}{c}\text { Quanto à } \\
\text { disposição }\end{array}$} & fasciculado & & & & & & & & & & & & & & & & \\
\hline & & ao acaso & & & & & & & & & & & & & & & & \\
\hline & \multirow{2}{*}{$\begin{array}{l}\text { Quanto à } \\
\text { superfície }\end{array}$} & justapostos & & & & & & & & & & & & & & & & \\
\hline & & à distância & & & & & & & & & & & & & & & & \\
\hline \multirow{6}{*}{$\begin{array}{l}0 \\
0 \\
\frac{0}{0} \\
\frac{\pi}{0} \\
0 \\
0 \\
0 \\
0 \\
0\end{array}$} & \multirow{3}{*}{ Núcleo(s) } & mitótico & & & & & & & & & & & & & & & & \\
\hline & & picnótico & & & & & & & & & & & & & & & & \\
\hline & & cariorrexe & & & & & & & & & & & & & & & & \\
\hline & \multirow{3}{*}{$\begin{array}{l}\text { Quanto à } \\
\text { superfície }\end{array}$} & à distância & & & & & & & & & & & & & & & & \\
\hline & & justapostos & & & & & & & & & & & & & & & & \\
\hline & & em lacunas & & & & & & & & & & & & & & & & \\
\hline \multirow{7}{*}{$\begin{array}{l}0 \\
0 \\
0 \\
\frac{\pi}{0} \\
0 \\
0 \\
\stackrel{0}{0} \\
\tilde{0} \\
0\end{array}$} & \multirow{3}{*}{ Núcleo } & mitótico & & & & & & & & & & & & & & & & \\
\hline & & picnótico & & & & & & & & & & & & & & & & \\
\hline & & cariorrexe & & & & & & & & & & & & & & & & \\
\hline & \multirow{2}{*}{$\begin{array}{c}\text { Quanto à } \\
\text { disposição }\end{array}$} & em paliçada & & & & & & & & & & & & & & & & \\
\hline & & ao acaso & & & & & & & & & & & & & & & & \\
\hline & \multirow{2}{*}{$\begin{array}{c}\text { Quanto à } \\
\text { superfície }\end{array}$} & justapostos & & & & & & & & & & & & & & & & \\
\hline & & à distância & & & & & & & & & & & & & & & & \\
\hline \multirow{6}{*}{ 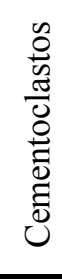 } & \multirow{3}{*}{ Núcleo(s) } & mitótico & & & & & & & & & & & & & & & & \\
\hline & & picnótico & & & & & & & & & & & & & & & & \\
\hline & & cariorrexe & & & & & & & & & & & & & & & & \\
\hline & \multirow{3}{*}{$\begin{array}{l}\text { Quanto à } \\
\text { superfície }\end{array}$} & à distância & & & & & & & & & & & & & & & & \\
\hline & & justapostos & & & & & & & & & & & & & & & & \\
\hline & & em lacunas & & & & & & & & & & & & & & & & \\
\hline
\end{tabular}

T - total; X - presença; c/ - com; s/ - sem; reabs - reabsorção; CGMN - células gigantes multinucleadas.

Figura 2 - Distribuição dos achados microscópicos referentes aos fenômenos morfologicamente detectados nos animais do Grupo ME 00 ou MC 00 
4 RESULTADOS 


\section{RESULTADOS}

Neste capítulo, serão descritas as características encontradas no periodonto de sustentação da raiz mesial do primeiro molar superior submetido à força externa.

\section{GRUPO CONTROLE}

O grupo controle corresponde ao hemiarco dentário superior não movimentado do animal. Os dados morfológicos descritos a seguir podem ser visualizados nas figuras 3, 4 e 5 e no capítulo Anexo $\mathrm{N}^{\mathrm{os}} 1,2,3,4,5,6$ e 7 .

Os cortes microscópicos analisados revelaram ligamento periodontal com largura constante e uniforme em toda sua extensão (Figura 3). Suas fibras colágenas mantiveram-se, em geral, paralelas entre si inserindo-se perpendicularmente às superfícies óssea e cementária. Os fibroblastos, dispostos em fascículos, apresentaram-se em formato fusiforme, alguns ovalados, com cromatina finamente granular (figura 4). Áreas hialinas não foram visualizadas e raras mitoses dos fibroblastos foram detectadas. Os vasos sangüíneos estavam distribuídos por todo o ligamento, com tamanho variado, e alguns se apresentando congestos. Também raras células inflamatórias e ilhotas de epitélio odontogênico foram identificadas neste ligamento (Figura 5).

Em geral, o tecido ósseo apresentou crista óssea levemente irregular, discretamente recortada, com poucos clastos dispostos em lacunas de Howship ou justapostos à superfície. Os osteoblastos dispunham-se justapostos à superfície arranjados em paliçada. As linhas de reversão estavam presentes em toda extensão óssea.

A superfície cementária apresentou-se uniforme e revestida por cementoblastos dispostos em paliçada, geralmente de maneira organizada, não sendo observadas lacunas de reabsorção. 


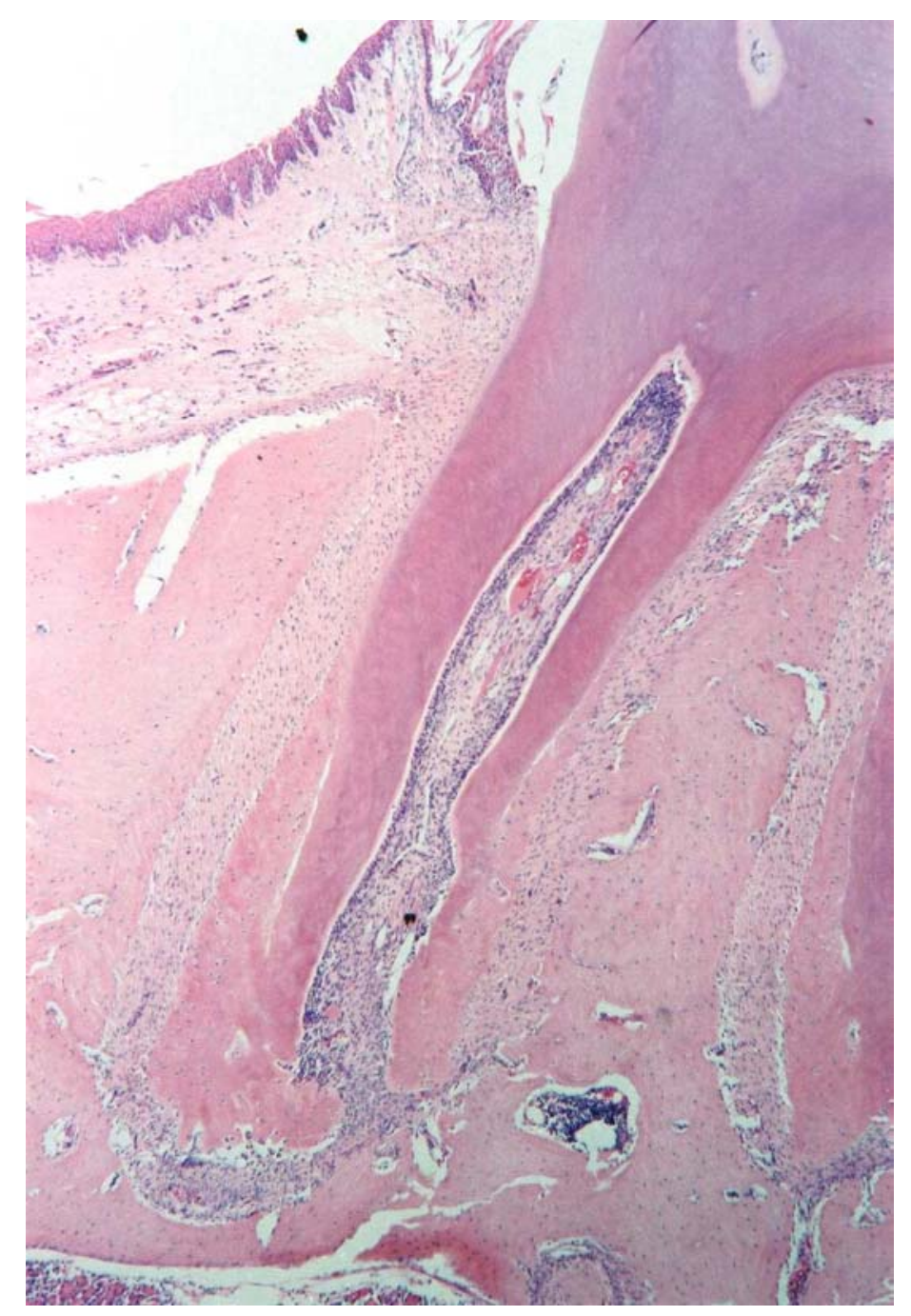

Figura 3 - Fotomicrografia panorâmica da raiz mesiovestibular do primeiro molar superior do Grupo Controle. As regiões marcadas corresponderão, nos Grupos Experimentais, aos lados de compressão e de tensão. $\mathrm{C}=$ lado de compressão; $\mathrm{T}$ = lado de tensão (Coloração H. E.; aumento Original - 50x) 


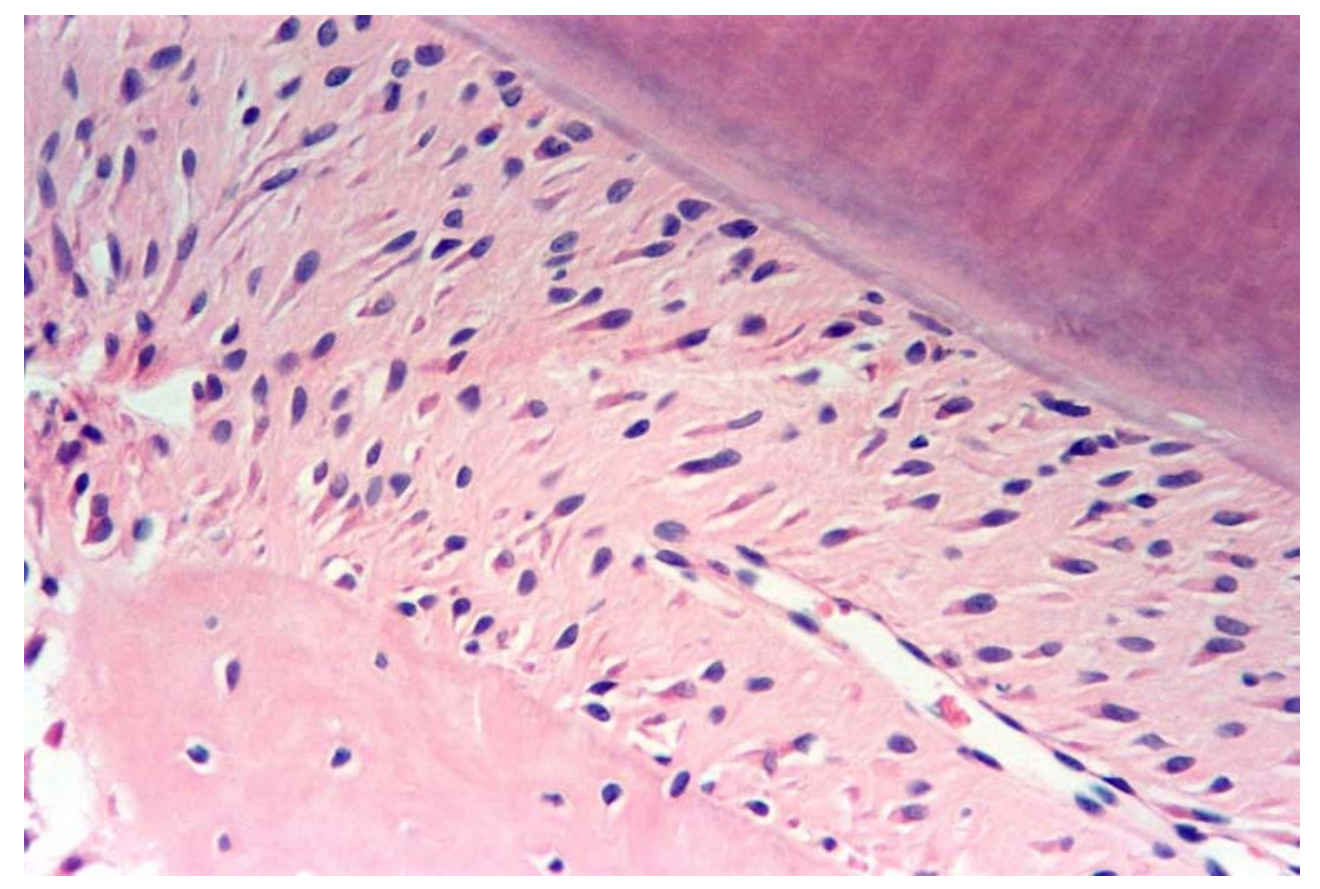

Figura 4 - Região cervical do lado mesial da raiz mesiovestibular do Grupo Controle. Notam-se ligamento periodontal ricamente celularizado; superfície óssea periodontal regular, parcialmente revestida por osteoblastos, e crista alveolar arredondada; superfície cementária uniforme, revestida por cementoblastos. $\mathrm{O}=$ osso; $\mathrm{L}=$ ligamento periodontal; $\mathrm{D}=$ dente (Coloração H. E.; Aumento Original $-100 \mathrm{x})$

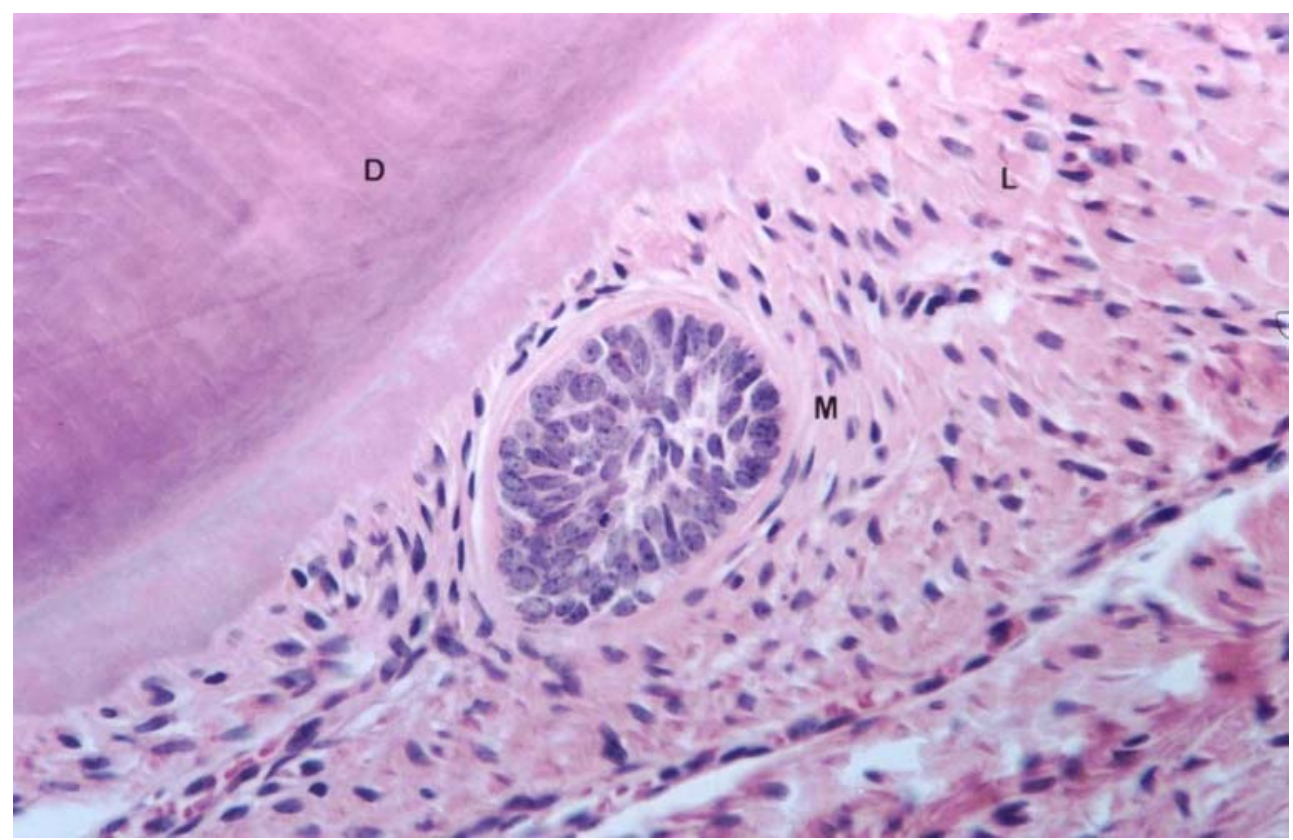

Figura 5 - Resto epitelial de Malassez localizado no ligamento periodontal. $\mathrm{D}=$ dente; $\mathrm{L}=$ ligamento periodontal; M - ilhota epitelial de Malassez (Coloração H.E.; Aumento Original - 400x) 


\section{GRUPOS EXPERIMENTAIS}

Os grupos experimentais correspondem ao hemiarco dentário superior no qual o primeiro molar sofreu aplicação de força.

\section{GRUPO 1}

Os dados morfológicos descritos a seguir podem ser visualizados nas figuras 6, 7 e 8 e no capítulo Anexo $\mathrm{N}^{\circ}$ 8, e se referem ao período de 24 horas.

Durante a análise microscópica os cortes correspondentes a este grupo revelaram alterações morfológicas celulares e teciduais em decorrência da ação da força aplicada. O lado de tensão do ligamento periodontal apresentou espessura discretamente aumentada, bastante celularizado com fibroblastos fusiformes, e alguns ovalados, fasciculados, alem de fibras colágenas perpendiculares, discretamente estiradas, oblíquas e paralelas entre si (Figura 6). Diminutas e poucas áreas hialinas foram observadas, vasos sangüíneos normais, alguns com discreta congestão e hemorragia. Raras figuras de mitoses, células polimorfonucleadas, mononucleadas e multinucleadas estavam presentes. O tecido ósseo mostrou crista recortada sem presença de atividade reabsortiva, com presença de linhas de reversão. Os osteoblastos localizavam-se justapostos à superfície, em sua maioria, dispondo-se em paliçada, observaram-se ainda poucos espaços medulares com presença de discreto infiltrado inflamatório mononuclear e presença de ocasional de osteoclastos focalmente distribuídos. A superfície cementária mostrou-se predominantemente regular, com presença de um sítio reabsortivo e presença de cementoclasto dentro da lacuna. Aqui os cementoblastos também estavam arranjados em paliçada em quase toda a superfície cementária e justapostos em outras áreas.

Os cortes microscópicos referentes ao lado de compressão do ligamento periodontal apresentaram discreto estreitamento na região mais cervical, estando bem celularizado com fibroblastos fasciculados em disposição aleatória e fibras colágenas oblíquas e paralelas entre si com arranjo relativamente frouxo (Figura 7). Observouse atividade vascular aumentada contendo vasos ora normais, ora comprimidos, alguns se apresentando congestos. Notou-se, ainda, discreta hemorragia pontual, em 
alguns casos. Nesta região, próxima aos vasos sangüíneos, algumas células semelhantes a macrófagos foram observadas, como também ocasionais células polimorfonucleadas e células gigantes multinucleadas. Estas últimas encontravam-se a uma certa distância da superfície óssea e radicular, não apresentavam bordas irregulares e ocorreram no ligamento periodontal. Não se detectaram áreas hialinas nem restos de epitélio odontogênico. O tecido ósseo exibiu crista arredondada, irregular com presença de cavidade reabsortiva inativa, bem como linhas de reversão (Figura 8). Os osteoblastos apresentavam-se arranjados em fascículos, ou ao acaso, alguns justapostos e outros à distância. A porção endosteal não apresentou espaços medulares. A superfície cementária apresentou-se regular, em geral, com presença de discreta área irregular com cavidade de reabsorção inativa. Os cementoblastos estavam justapostos em toda extensão cementária e dispostos em paliçada.

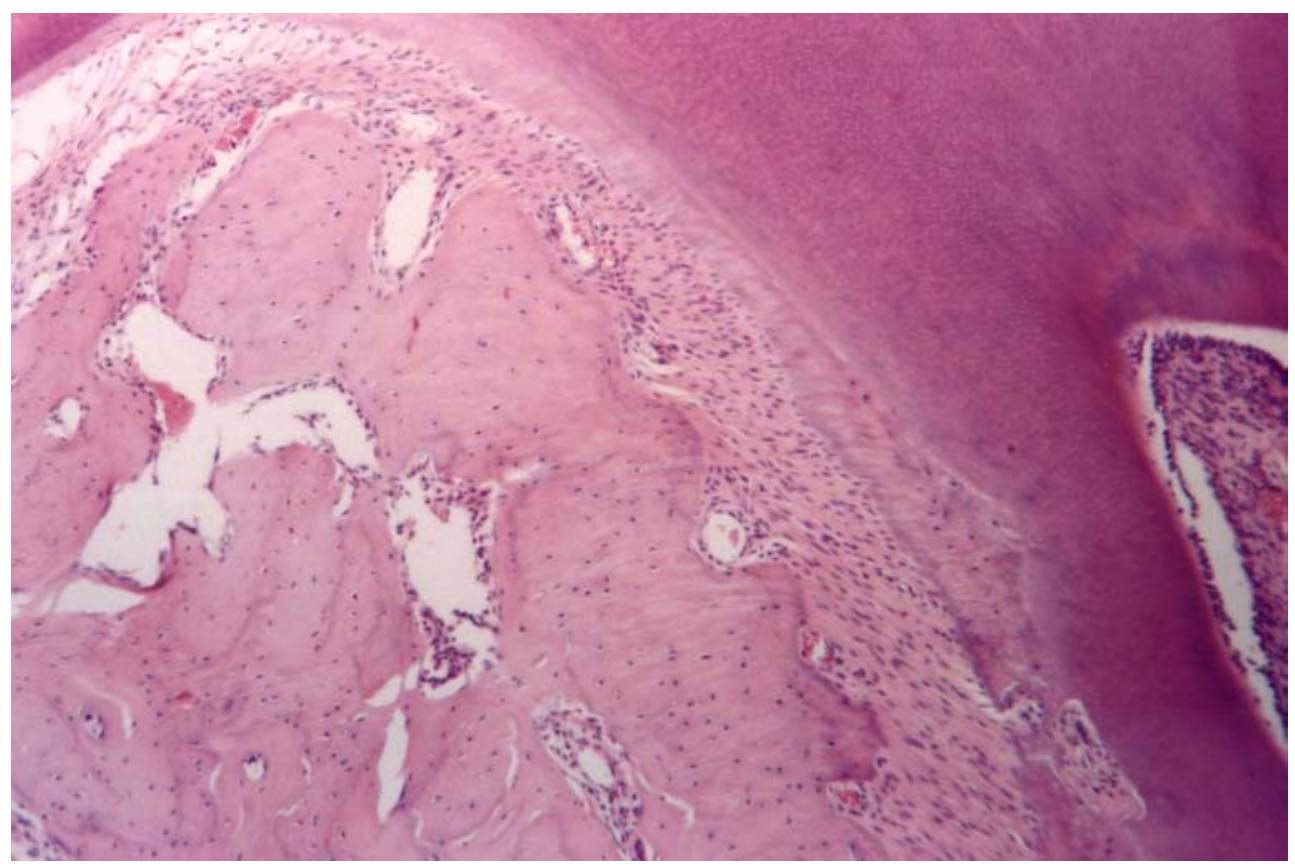

Figura 6 - Região cervical do lado de tensão da raiz mesiovestibular do Grupo 1. Notam-se ligamento periodontal ricamente celularizado, com fibras colágenas tensionadas; superfície óssea irregular apresentando linhas de reversão. $\mathrm{O}=$ osso; $\mathrm{L}=$ ligamento periodontal; $\mathrm{D}=$ dente (Coloração H. E.; Aumento Original $-100 \mathrm{x}$ ) 


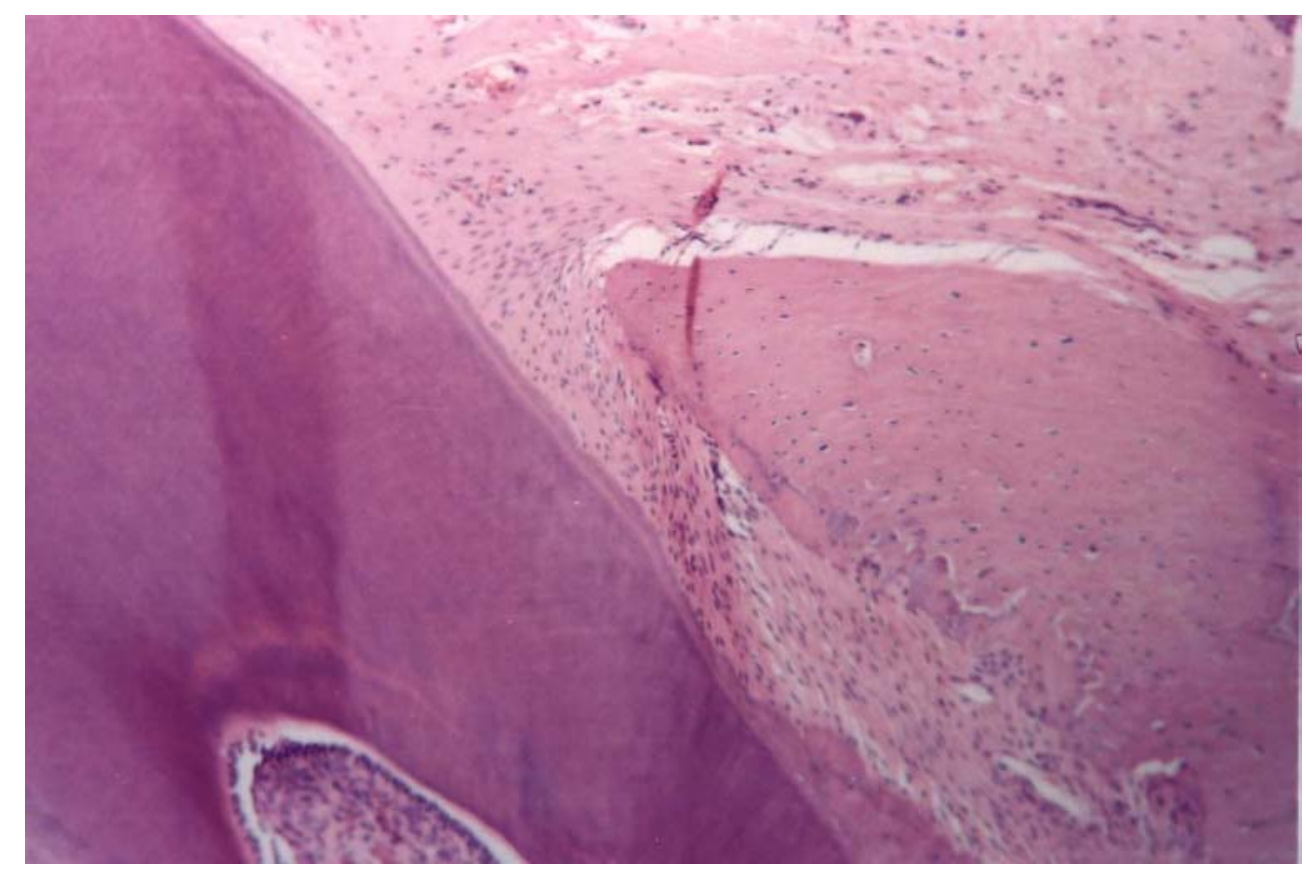

Figura 7 - Região cervical do lado de compressão da raiz mesiovestibular do Grupo 1. Notam-se ligamento periodontal ricamente celularizado; superfície óssea periodontal levemente recortada no terço médio com e crista alveolar arredondada; superfície cementária uniforme, revestida por cementoblastos. $\mathrm{O}=$ osso; $\mathrm{L}=$ ligamento periodontal; $\mathrm{D}=$ dente (Coloração H. E.; Aumento Original $-100 \mathrm{x}$ )

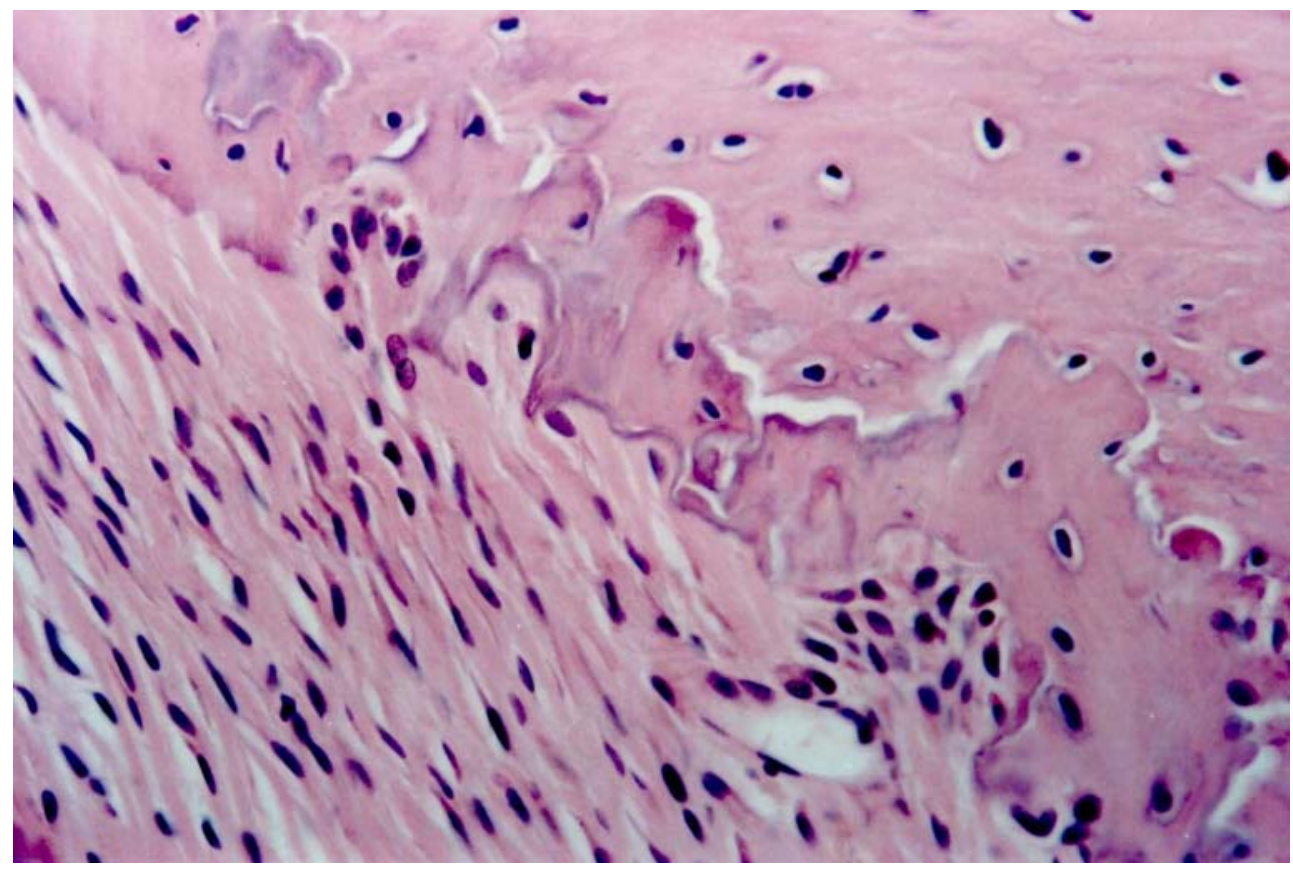

Figura 8 - Maior aumento da área irregular da superfície óssea periodontal evidenciando cavidades reabsortivas inativas e linhas de reversão. $\mathrm{O}=$ osso; $\mathrm{L}=$ ligamento periodontal; $\mathrm{R}=$ linhas de reversão (Coloração $\mathrm{H}$. E.; Aumento Original - 400x) 


\section{GRUPO 2}

Os dados morfológicos descritos a seguir podem ser visualizados nas figuras 9, 10 e 11 e no capítulo Anexo No 9, e se referem ao período de dois dias.

Durante a análise microscópica os cortes correspondentes a este grupo revelaram alterações morfológicas celulares e teciduais em decorrência da ação da força aplicada. As regiões de tensão cervical e apical do ligamento periodontal, discretamente aumentadas, apresentaram fibras colágenas estiradas, oblíquas e paralelas entre si, além de fibroblastos fusiformes formando fascículos (Figura 9). De permeio observou-se discreto infiltrado inflamatório mononuclear contendo linfócitos, macrófagos, vasos sangüíneos congestos e discreta hemorragia, além de raras figuras de mitose. O tecido ósseo mostrou-se irregular, com a crista recortada e cavidades reabsortivas inativas e delineadas por linhas de reversão. Os osteoblastos apresentavam-se em paliçada e os osteoclastos em lacunas. A superfície endosteal apresentou discreto infiltrado inflamatório mononuclear mais condensado com presença de células gigantes multinucleadas focais e poucos espaços medulares. A superfície cementária mostrou-se uniforme com cementoblastos justapostos à superfície, arranjados ora em paliçada, ora ao acaso.

Nos cortes microscópicos referentes à região de compressão cervical, o ligamento periodontal, de espessura discretamente diminuída, apresentou fibras colágenas com disposição frouxa e fibroblastos fusiformes fasciculados, alguns ovalados e aleatórios. Raras figuras de mitoses e pequenas áreas em processo de hialinização foram identificadas, além da presença de discreto infiltrado inflamatório mononuclear, vasos sangüíneos congestos e discreta hemorragia. O tecido ósseo, na superfície periodontal, ora apresentava irregularidade da crista com presença de cavidades reabsortivas delineadas por linhas de reversão, caracterizando processo de reparo, ora apresentava unidades de reabsorção constituídas por clastos multinucleados, presentes em lacunas, demonstrando franca atividade reabsortiva. Os osteoblastos dispunham-se justapostos à superfície e nos locais onde não ocorria reabsorção. A porção endosteal não apresentou espaços medulares. A superfície cementária apresentou-se uniforme, sem lacunas de reabsorção, revestida por cementoblastos justapostos e dispostos ao acaso. 
A região de compressão apical apresentou ligamento periodontal comprimido contendo fibras colágenas arranjadas frouxamente com fibroblastos dispostos de permeio, poucas e pequenas áreas de hialinização, vasos sangüíneos congestos e discreto infiltrado inflamatório mononuclear com predomínio de linfócitos (Figuras 10 e 11). Clastos multinucleados estavam presentes em unidades reabsortivas na superfície óssea.

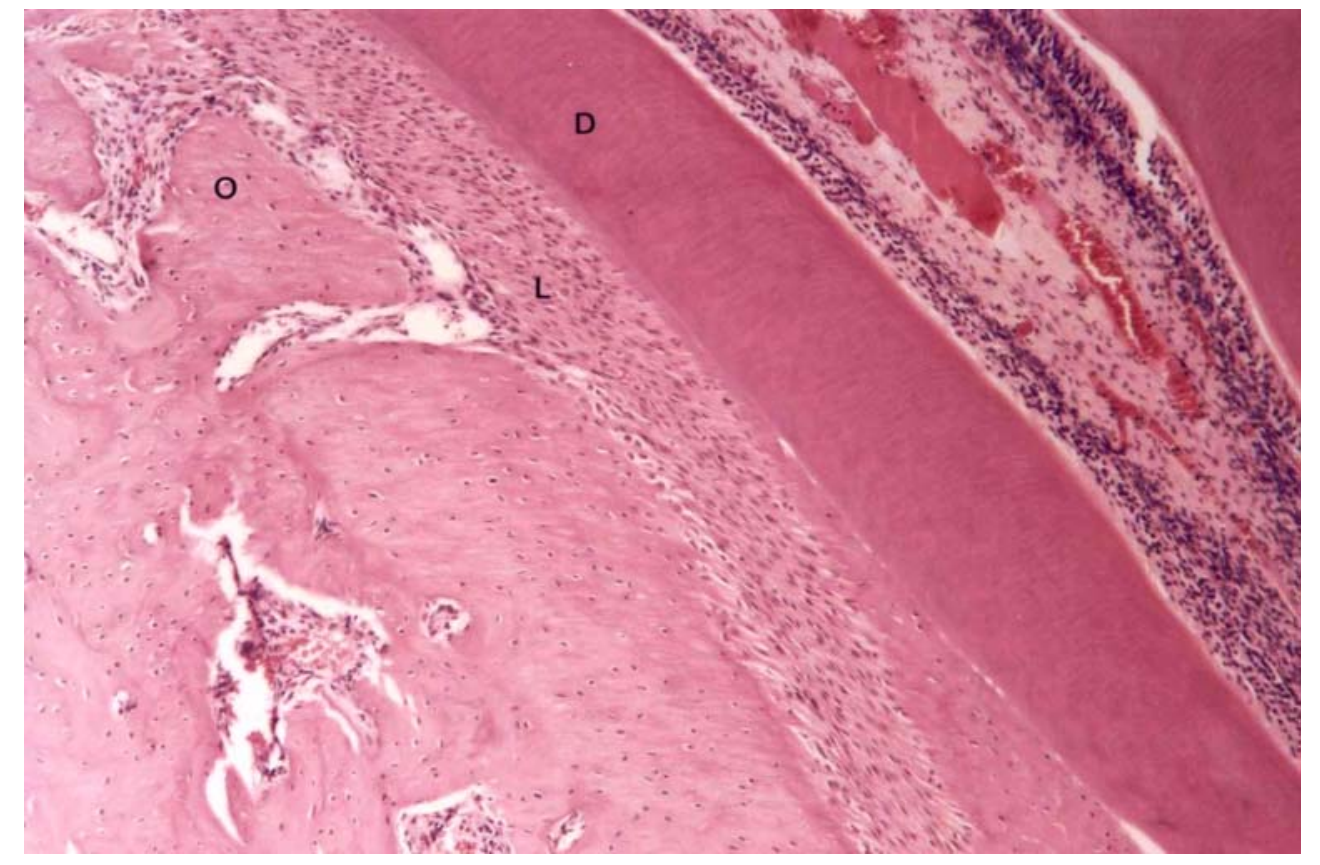

Figura 9 - Região cervical do lado de tensão da raiz mesiovestibular do Grupo 2. Notam-se ligamento periodontal ricamente celularizado; superfície óssea periodontal uniforme em seu terço superior sem lacunas de reabsorção; superfície cementária uniforme, revestida por cementoblastos. $\mathrm{O}=$ osso; $\mathrm{L}=$ ligamento periodontal; $\mathrm{D}$ = dente (Coloração H. E.; Aumento Original - 100x) 


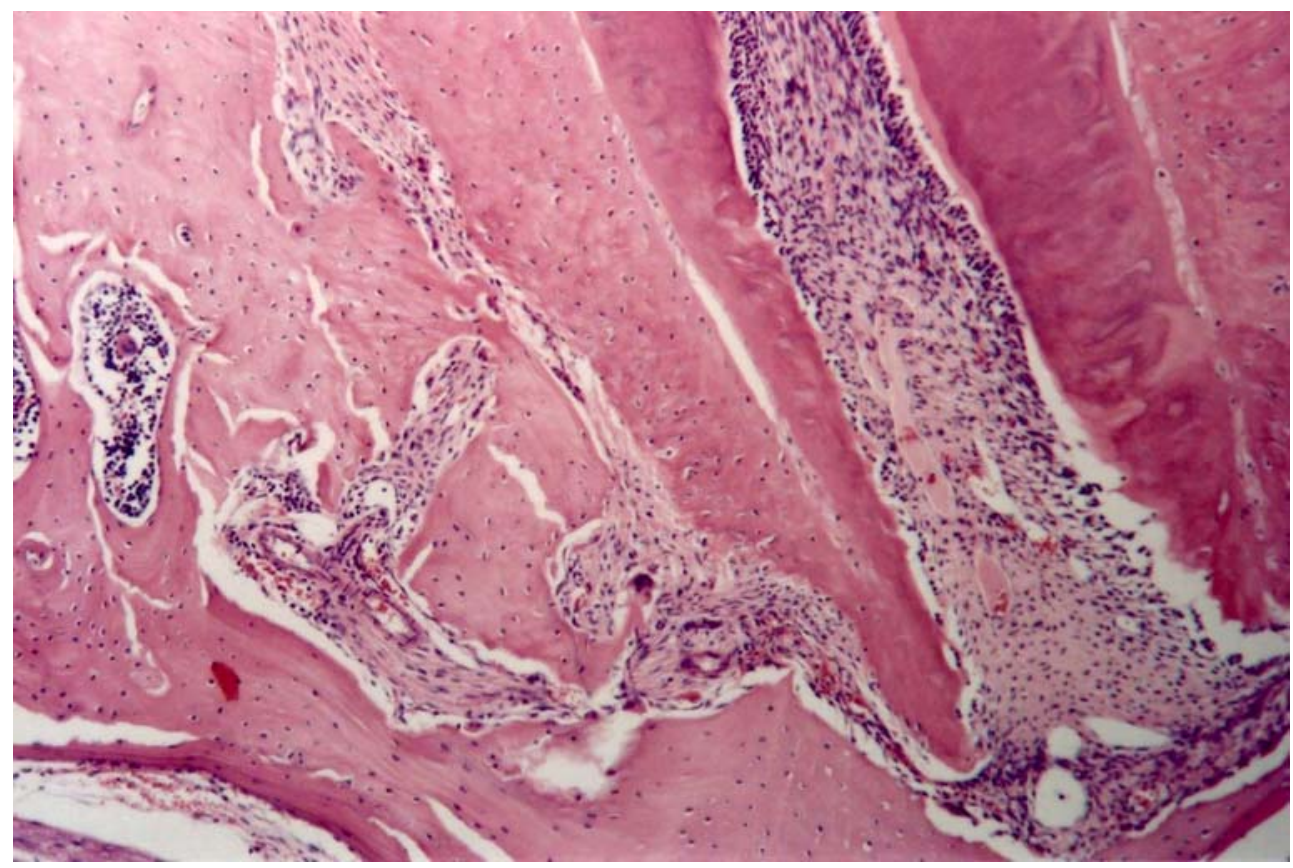

Figura 10 - Região apical do lado de compressão da raiz mesiovestibular no Grupo 2. Notam-se ligamento periodontal com espessura diminuída; superfície óssea irregular. $\mathrm{O}=\mathrm{osso}$; $\mathrm{L}=$ ligamento periodontal; D = dente (Coloração H. E.; Aumento Original - 100x)

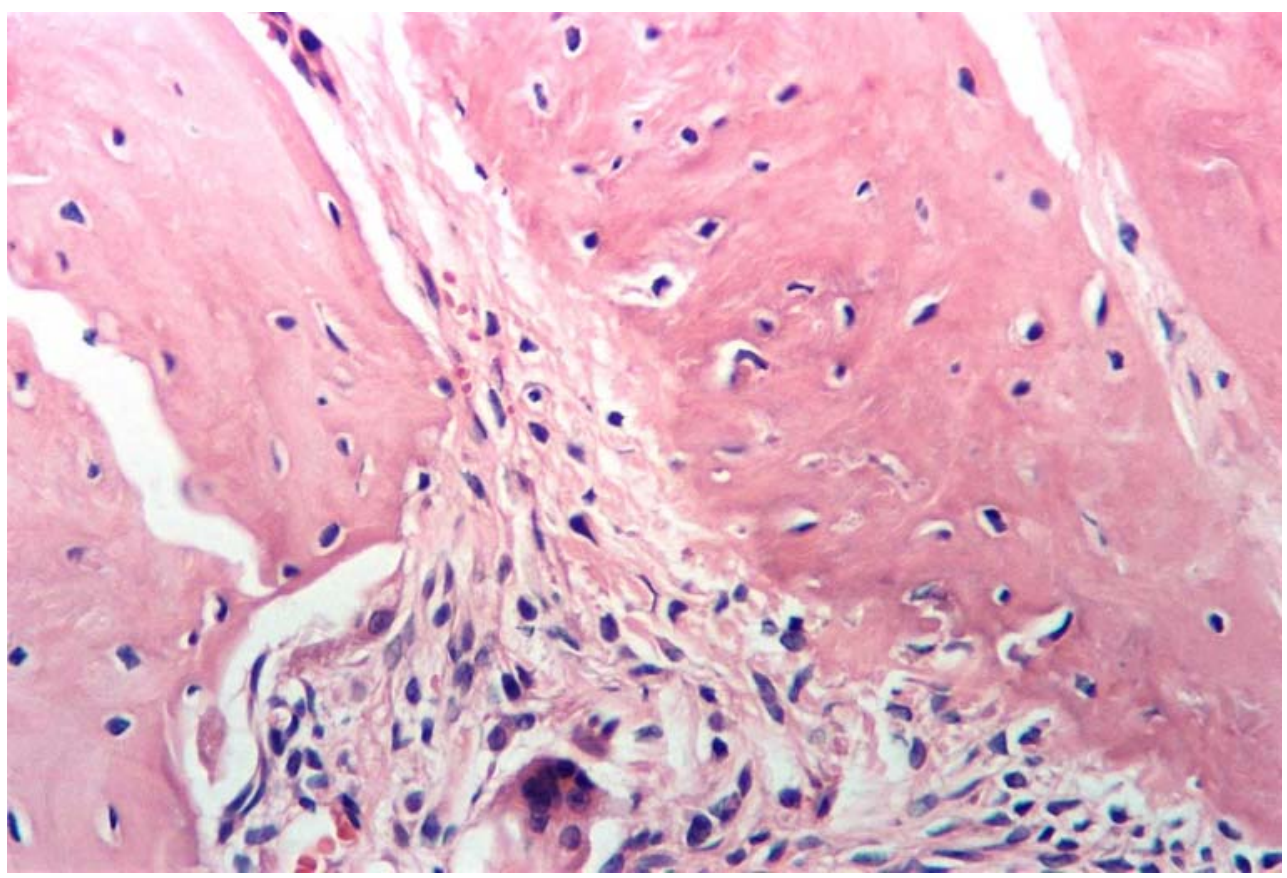

Figura 11 - Maior aumento da área de compressão apical do Grupo 2. Notam-se ligamento periodontal com fibroblastos em disposição aleatória, além das pequenas áreas hialinas; superfície óssea revestida parcialmente por osteoblastos com presença de um osteoclasto à distância; superfície cementária uniforme. $\mathrm{O}=$ osso; $\mathrm{L}=$ ligamento periodontal; $\mathrm{D}=$ dente; $\mathrm{H}=$ área hialina (Coloração $\mathrm{H}$. E.; Aumento Original - 400x) 


\section{GRUPO 3}

Os dados morfológicos descritos a seguir podem ser visualizados nas figuras 12, 13 e 14 e no capítulo Anexo $\mathrm{N}^{\circ} 10$, e se referem ao período de três dias.

Durante a análise microscópica os cortes correspondentes a este grupo revelaram alterações morfológicas celulares e teciduais em decorrência da ação da força aplicada. As regiões de tensão cervical e apical apresentavam características semelhantes com alargamento do ligamento periodontal, que continham fibras colágenas estiradas, oblíquas e paralelas entre si, além de fibroblastos fasciculados predominantemente fusiformes (Figura 12). De permeio observou-se discreto infiltrado inflamatório mononuclear contendo linfócitos, macrófagos, vasos sangüíneos congestos e discreta hemorragia, além de raras figuras de mitose e células polimorfonucleadas, tipo neutrófilos. A superfície óssea na porção periodontal mostrou-se irregular, no entanto as cavidades reabsortivas estavam inativas, com presença de linhas de reversão. Os osteoblastos apresentavam-se em disposição aleatória e alguns justapostos. A porção endosteal apresentou moderado infiltrado inflamatório mononuclear com ocasionais células gigantes multinucleadas. A superfície cementária mostrou-se levemente irregular, sem lacunas de reabsorção, e estava revestida por cementoblastos justapostos. Havia raros cementoclastos mais à distância.

Os cortes microscópicos referentes à região de compressão cervical do ligamento periodontal, com espessura diminuída, apresentou fibras colágenas discretamente desorganizadas e disposição frouxa, preenchendo o espaço intercelular (Figura 13). Os fibroblastos apresentavam formato predominantemente fusiformes, com alguns ovalados, distribuídos em fascículos. Pequenas áreas em processo de hialinização estavam presentes em meio a discreto infiltrado inflamatório mononuclear, com presença de raras células polimorfonucleadas, tipo neutrófilos, pequenos vasos sangüíneos congestos e discreta hemorragia focal. O tecido ósseo apresentou face periodontal recortada com crista afilada contendo osteoclastos justapostos à superfície, indicando atividade reabsortiva em alguns segmentos, enquanto outros mostravam áreas onde o processo de reabsorção estava estagnado e delineadas por linhas de reversão, caracterizando processo de reparo (Figura 14). A 
superfície óssea estava parcialmente revestida por osteoblastos em disposição aleatória, mas justapostos, ou à distância, enquanto os osteoclastos presentes preenchiam lacunas de reabsorção. A porção endosteal não apresentou espaços medulares. A superfície cementária apresentou-se uniforme, sem lacunas de reabsorção, revestida por cementoblastos.

A região de pressão apical apresentou as mesmas características da área de compressão cervical, no entanto o discreto infiltrado inflamatório mononuclear apresentou-se mais concentrado e com predomínio de linfócitos.

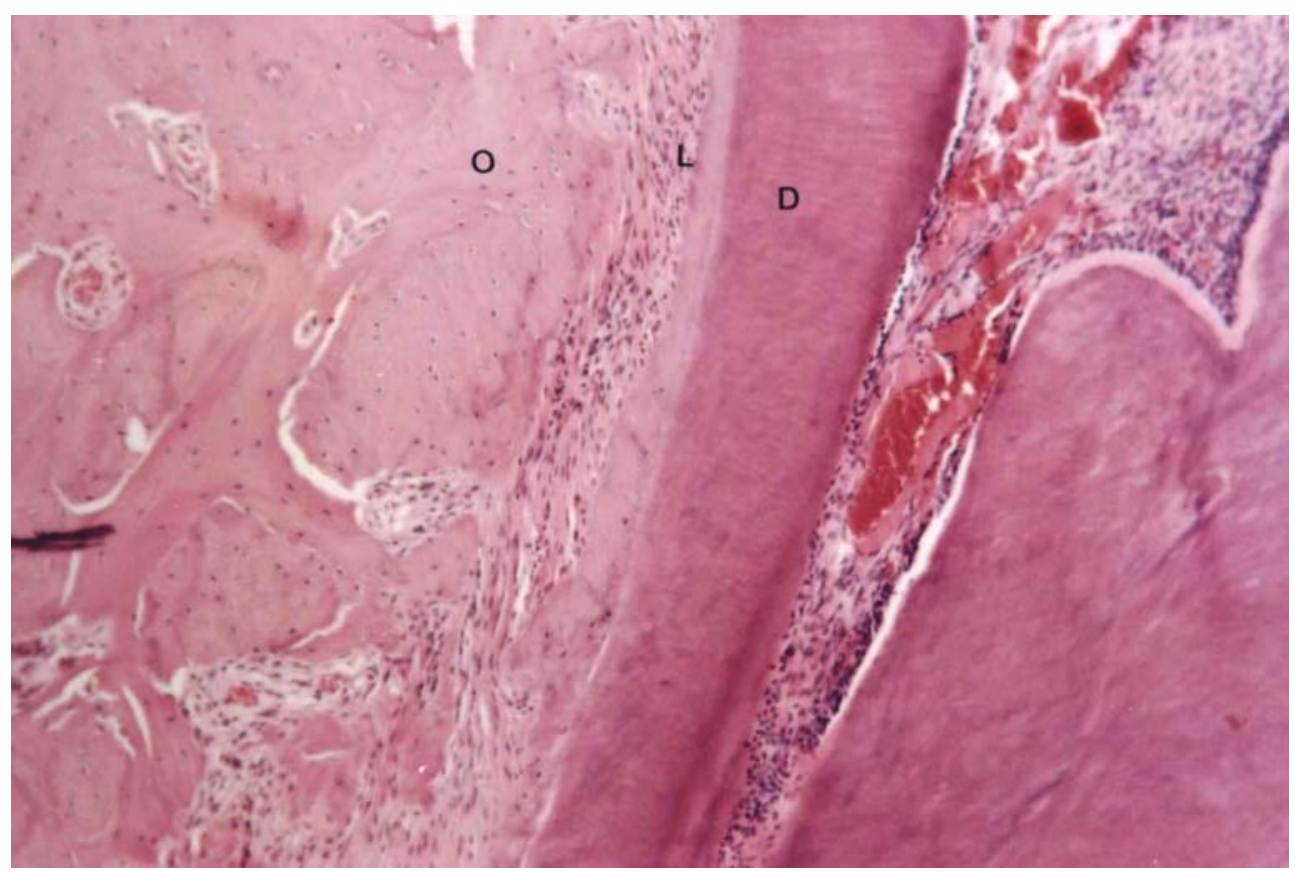

Figura 12 - Região cervical do lado de tensão da raiz mesiovestibular do Grupo 3. Notam-se ligamento periodontal ricamente celularizado; superfície óssea periodontal regular; superfície cementária uniforme. $\mathrm{O}$ = osso; $\mathrm{L}$ = ligamento periodontal; $\mathrm{D}$ = dente (Coloração H. E.; Aumento Original - 100x) 


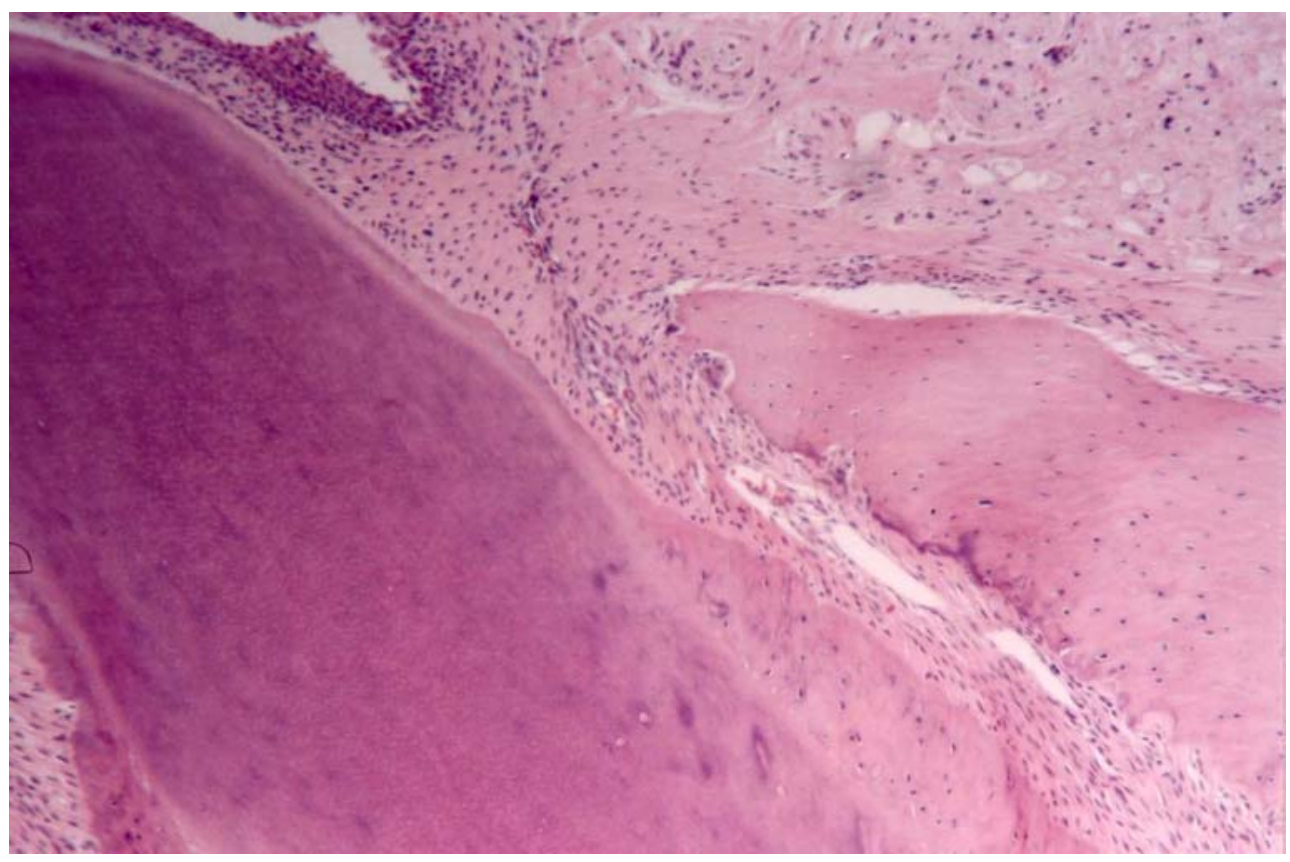

Figura 13 - Região cervical do lado de compressão da raiz mesiovestibular do Grupo 3. Notam-se ligamento periodontal com espessura diminuída, ricamente celularizado; superfície óssea periodontal com áreas de irregularidade, linhas de reversão e crista alveolar afilada; superfície cementária uniforme, revestida por cementoblastos. $\mathrm{O}=$ osso; $\mathrm{L}=$ ligamento periodontal; $\mathrm{D}=$ dente (Coloração H. E.; Aumento Original - 100x)

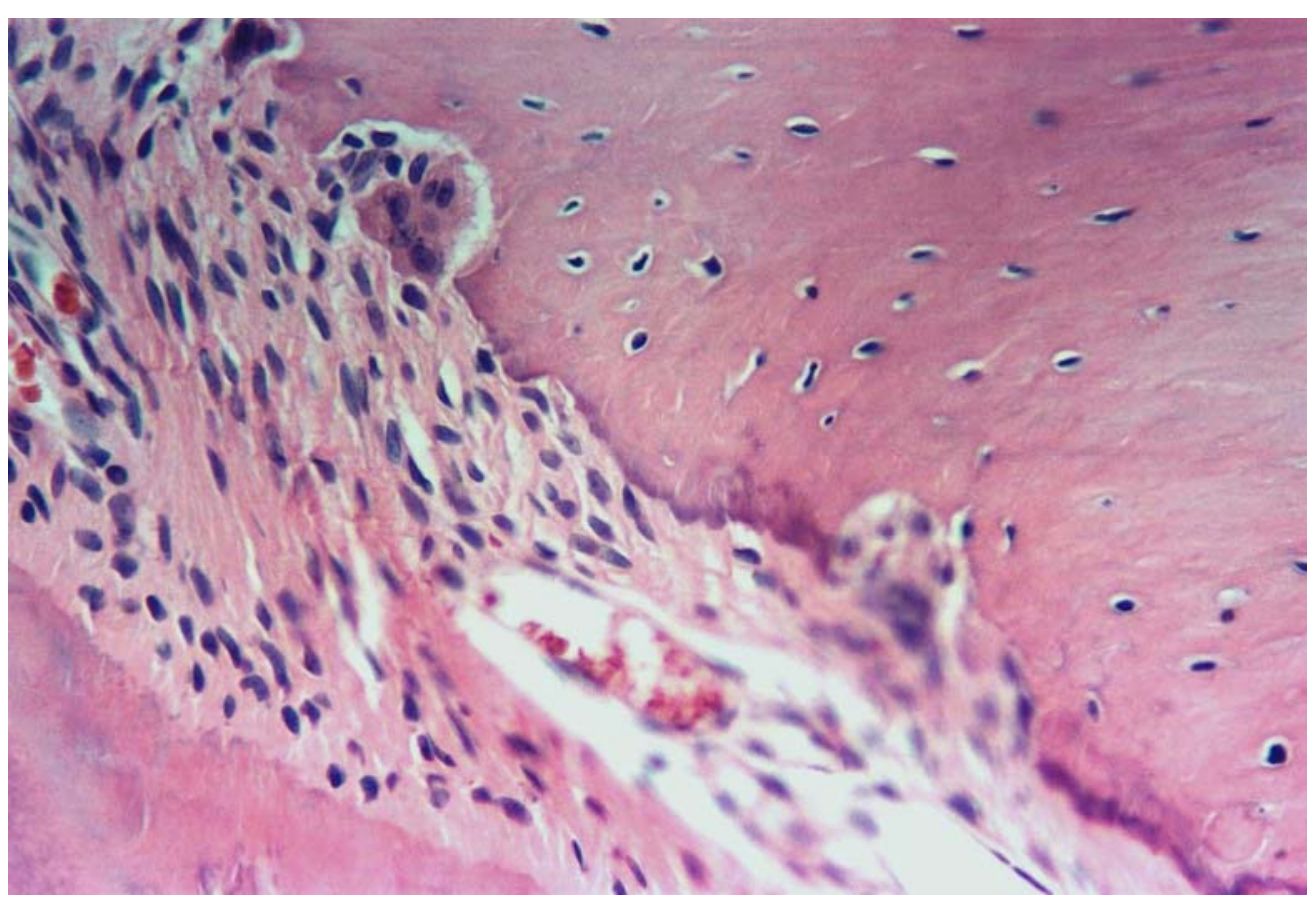

Figura 14 - Maior aumento da área de compressão cervical do Grupo 3. Notam-se ligamento periodontal ricamente celularizado com pequenas áreas hialinas; superfície óssea periodontal com unidades de reabsorção alternadas; superfície cementária uniforme, revestida por cementoblastos. $\mathrm{O}=$ osso; $\mathrm{H}=$ área hialina; $\mathrm{D}=$ dente, $\mathrm{U}=$ unidade de reabsorção (Coloração H. E.; Aumento Original - 400x) 


\section{GRUPO 4}

Os dados morfológicos descritos a seguir podem ser visualizados nas figuras 15 e 16 e no capítulo Anexo 11, e se referem ao período de quatro dias.

Durante a análise microscópica, cortes correspondentes a este grupo revelaram alterações morfológicas celulares e teciduais em decorrência da ação da força aplicada. As regiões de tensão cervical e apical do ligamento periodontal apresentaram-se com aspectos semelhantes, com seu espaço aumentado, contendo fibras colágenas estiradas, oblíquas ao osso e cemento e paralelas entre si, além de fibroblastos fusiformes maduros formando fascículos (Figura 15). De permeio havia poucas e pequenas áreas hialinas, poucas e esparsas células inflamatórias, vasos sangüíneos congestos e discreta hemorragia, além de raras figuras de mitose. $\mathrm{O}$ tecido ósseo apresentou a face periodontal irregular com presença de cavidades reabsortivas inativas, porém sem linhas de reversão. Os osteoblastos apresentavam-se ora justapostos, ora ao acaso, ora em disposição fasciculada, ora à distância, enquanto os osteoclastos estavam à distância. A porção endosteal apresentou moderado infiltrado inflamatório mononuclear com múltiplas células gigantes multinucleadas esparsas. Neste período experimental, havia uma maior quantidade de espaços medulares. A superfície cementária mostrou-se uniforme com presença de áreas irregulares e outras com cementóide. Não se observou reabsorção dentinária, no entanto em um dos animais detectou-se área de reabsorção radicular. Os cementoblastos formavam um arranjo em paliçada e mostravam-se justapostos à superfície. Os cementoclastos estavam em lacuna.

Os cortes microscópicos referentes à região de compressão cervical do ligamento periodontal apresentaram-se com espessura diminuída. Dentre seus componentes, os fibroblastos maduros e predominantemente fusiformes exibiam arranjo aleatório por entre fibras colágenas desorganizadas com arranjo frouxo e disposição aleatória (Figura 16). Observaram-se áreas de hialinização, vasos sangüíneos congestos e discreta hemorragia, além da presença de discreto infiltrado inflamatório mononuclear, mas em maior quantidade que o Grupo anterior. Ocasionais células polimorfonucleadas e multinucleadas estavam presentes. $\mathrm{O}$ tecido ósseo apresentou face periodontal recortada com linhas de reversão e crista afilada 
com áreas específicas apresentando sítios de reabsorção. Os osteoblastos estavam arranjados aleatoriamente, enquanto os osteoclastos podiam ser vistos justapostos à superfície, à distância ou preenchendo lacunas de reabsorção. A porção endosteal não apresentou espaços medulares. A superfície cementária apresentou-se com discreta área irregular e lacuna de reabsorção inativa. Os cementoblastos estavam dispostos em paliçada e justapostos à superfície em quase toda a extensão cementária, e os cementoclastos dispostos nas proximidades.

A região de compressão apical apresentou as mesmas características da área cervical, além de apresentar osteoclastos multinucleados presentes em unidades reabsortivas.

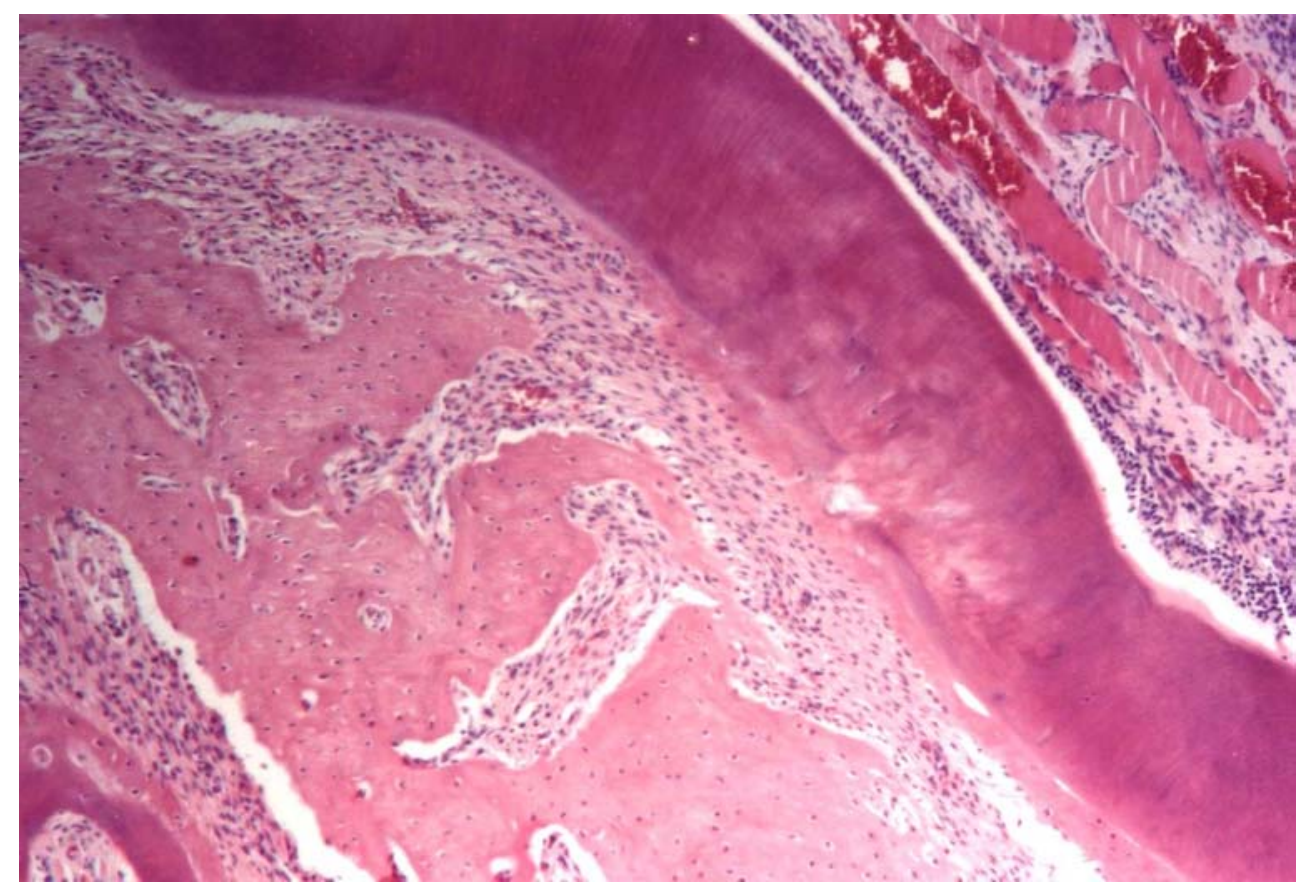

Figura 15 - Região cervical do lado de tensão da raiz mesiovestibular do Grupo 4. Notam-se ligamento periodontal ricamente celularizado, com pontos focais de hemorragia e discreta congestão vascular; superfície óssea periodontal com áreas de irregularidade; superfície cementária uniforme, revestida por cementoblastos. $\mathrm{O}=$ osso; $\mathrm{L}=$ ligamento periodontal; $\mathrm{D}=$ dente (Coloração H. E.; Aumento Original 100x) 


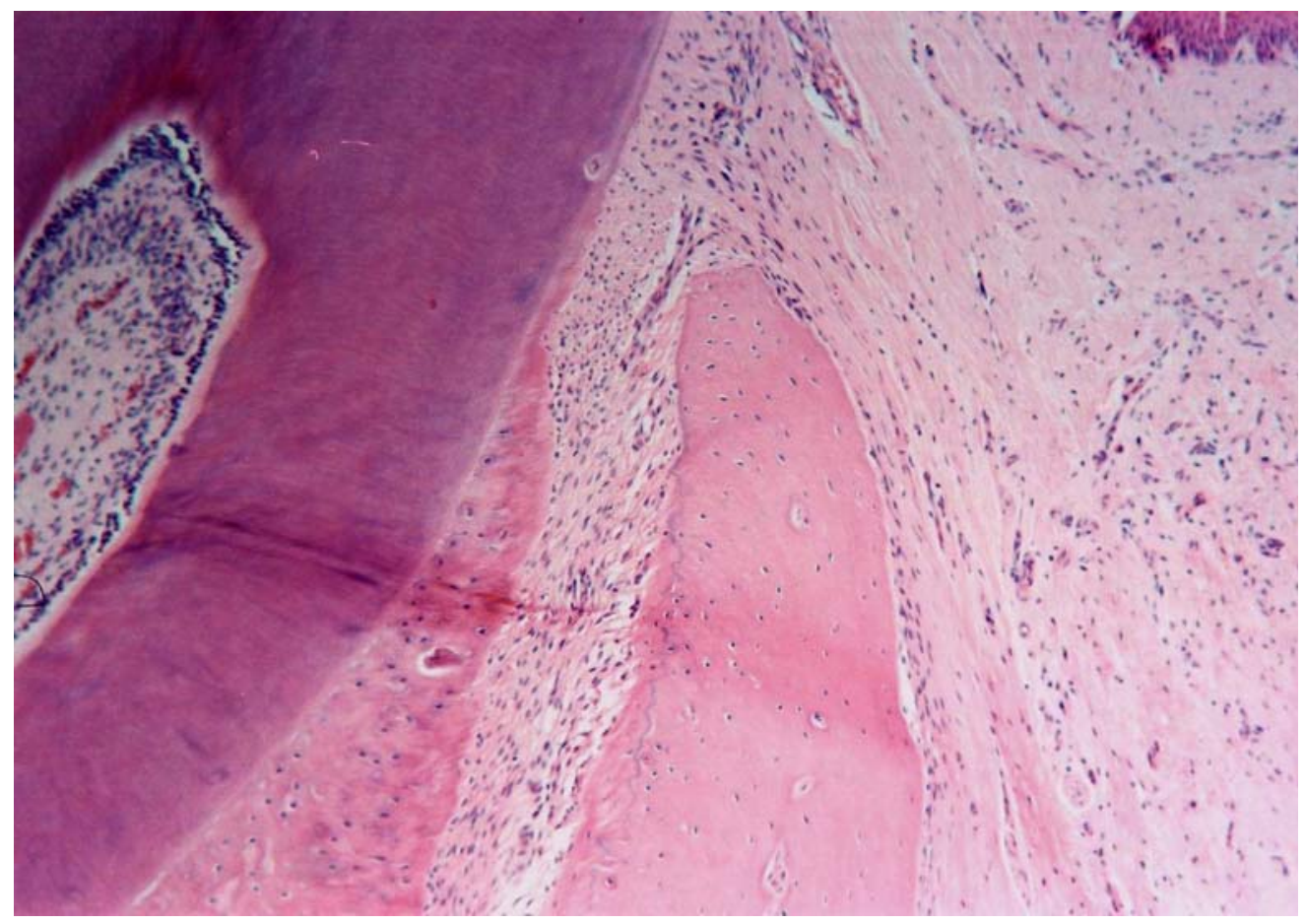

Figura 16 - Região cervical do lado de compressão da raiz mesiovestibular do Grupo 4. Notam-se ligamento periodontal ricamente celularizado; superfície óssea periodontal regular com poucas linhas de reversão; superfície cementária uniforme. $\mathrm{O}=$ osso; $\mathrm{L}=$ ligamento periodontal; $\mathrm{D}=$ dente (Coloração H. E.; Aumento Original - 100x) 


\section{GRUPO 5}

Os dados morfológicos descritos a seguir podem ser visualizados nas figuras 17, 18 e 19 e no capítulo Anexo $\mathrm{N}^{\circ} 12$, e se referem ao período de cinco dias.

Durante a análise microscópica, os cortes correspondentes a este grupo revelaram alterações morfológicas celulares e teciduais em decorrência da ação da força aplicada. As regiões de tensão cervical e apical do ligamento periodontal mostraram-se aumentadas em sua espessura contendo fibras colágenas estiradas, oblíquas e paralelas entre si, além de fibroblastos fusiformes e maduros formando fascículos (Figura 17). De permeio observou-se discreto infiltrado inflamatório mononuclear representado por linfócitos e macrófagos. Também se visualizou vasos sangüíneos congestos e discreta hemorragia, além de raras figuras de mitose e poucas áreas hialinas. Em um dos animais também foi visualizado epitélio odontogênico, semelhante a restos epiteliais de Malassez. O tecido ósseo apresentou superfície levemente irregular, sem linhas de reversão, com cavidades reabsortivas inativas. Os osteoblastos apresentavam-se justapostos à superfície e ao acaso, enquanto os osteoclastos estavam à distância. A porção endosteal apresentou amplos espaços medulares e condensado infiltrado inflamatório mononuclear com presença de múltiplas células gigantes multinucleadas. A superfície cementária mostrou-se regular com presença de cementóide. Não se observou reabsorção dentinária. Os cementoblastos mostravam-se justapostos à superfície e ao acaso.

Os cortes microscópicos referentes à região de compressão cervical do ligamento periodontal apresentaram espessura diminuída sendo constituído por fibras colágenas desorganizadas com disposição frouxa e aleatória e fibroblastos fusiformes maduros formando fascículos, estando alguns aleatórios. Áreas hialinas pequenas, discreto infiltrado inflamatório mononuclear, vasos sangüíneos congestos e pontos focais de hemorragia estavam presentes nas regiões de compressão cervical e apical. O tecido ósseo mostrou-se com face periodontal irregular bastante recortada, com lacunas ósseas não ativas, sem linhas de reversão e com crista afilada (Figura 18 e 19). Nas outras regiões os osteoblastos estavam justapostos à superfície. A porção endosteal não apresentou espaços medulares. A superfície cementária apresentou-se 
uniforme com discreta irregularidade em sua superfície, sendo revestida parcialmente por cementoblastos justapostos e ao acaso.

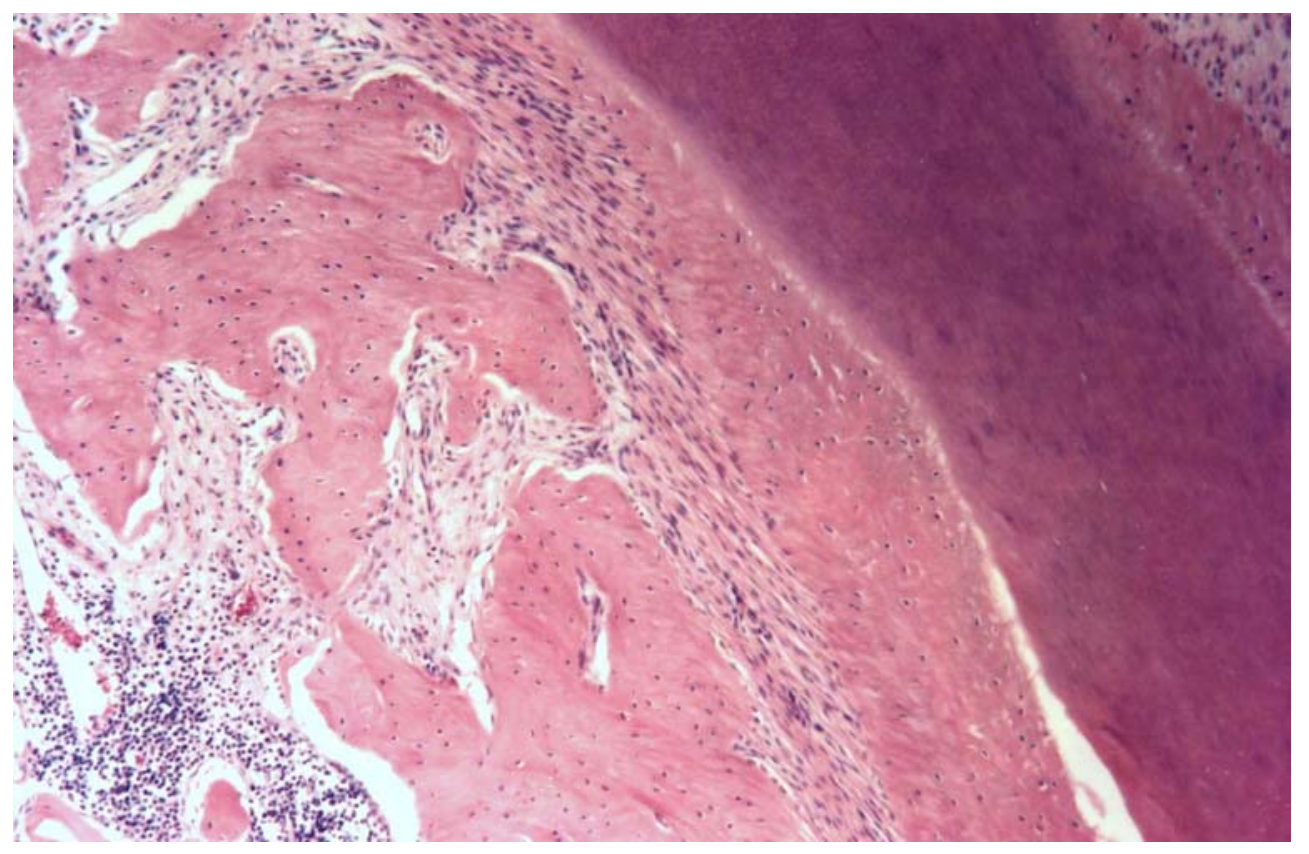

Figura 17 - Região cervical do lado de tensão da raiz mesiovestibular do Grupo 5. Notam-se ligamento periodontal ricamente celularizado com fibras colágenas distendidas; superfícies óssea periodontal e cementária uniformes. $\mathrm{O}=$ osso; $\mathrm{L}=$ ligamento periodontal; D = dente (Coloração H. E.; Aumento Original - 100x) 


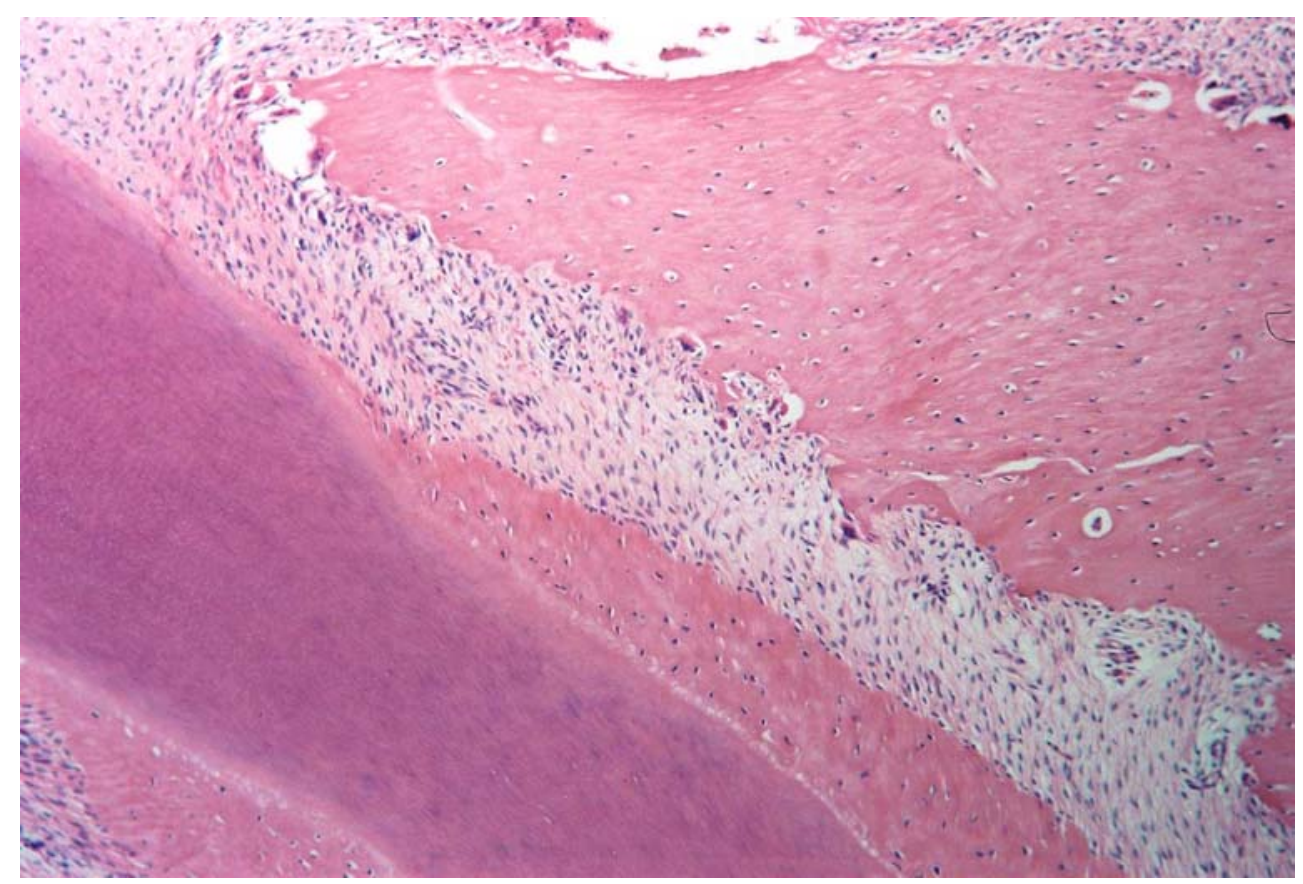

Figura 18 - Região cervical do lado de compressão da raiz mesiovestibular do Grupo 5. Notam-se ligamento periodontal ricamente celularizado; superfície óssea periodontal recortada com unidades de reabsorção e crista alveolar irregular; superfície cementária uniforme. $\mathrm{O}=0 \mathrm{osso} ; \mathrm{L}=$ ligamento periodontal; D $=$ dente (Coloração H. E.; Aumento Original - 100x)

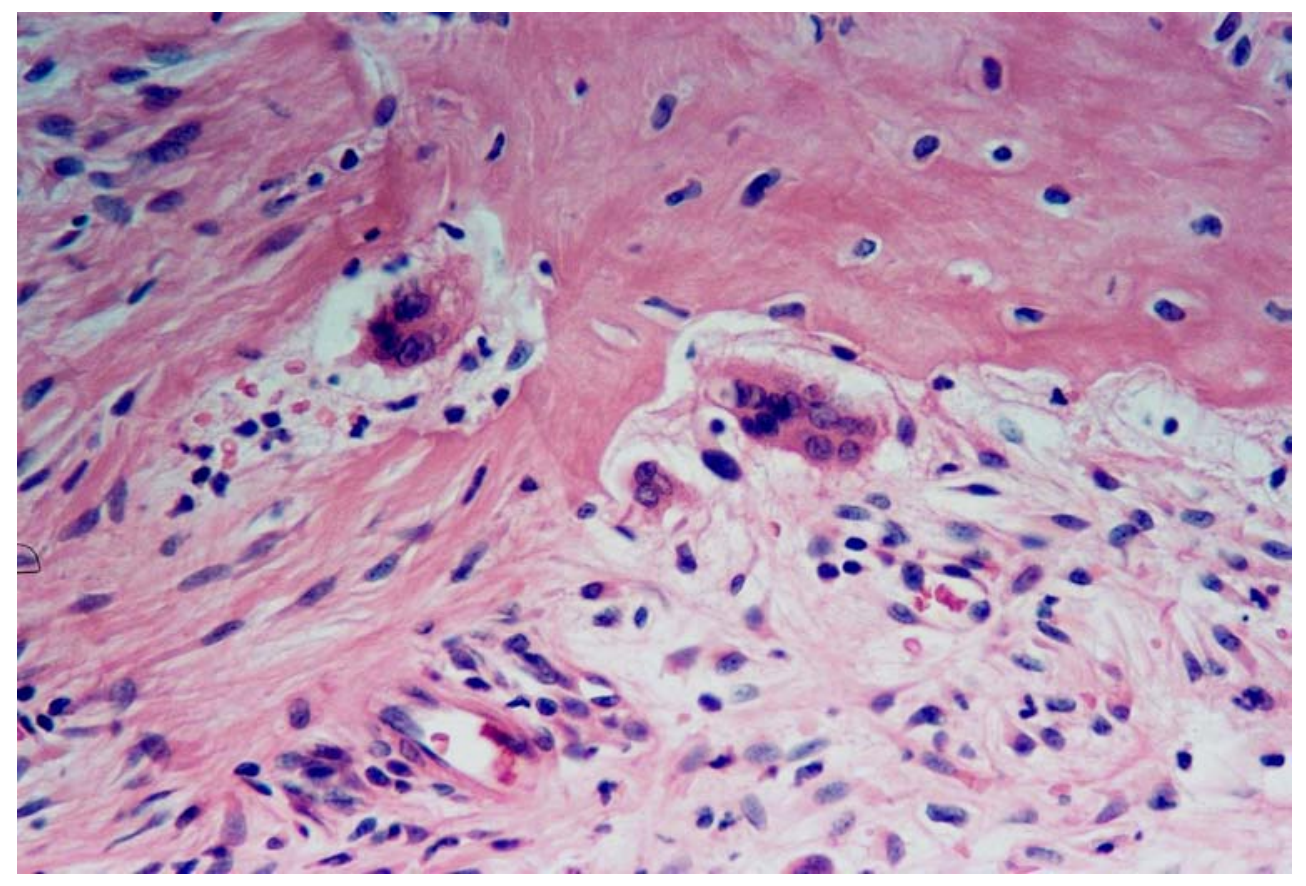

Figura 19 - Maior aumento da região de compressão do Grupo 5. Notam-se discretas áreas hialinas, unidades de reabsorção e múltiplos vasos sangüíneos. $\mathrm{O}=$ osso; $\mathrm{L}=$ ligamento periodontal; $\mathrm{D}=$ dente; $\mathrm{U}=$ unidade de reabsorção (Coloração H. E.; Aumento Original - 400x) 


\section{GRUPO 6}

Os dados morfológicos descritos a seguir podem ser visualizados nas figuras 20, 21 e 22 e no capítulo Anexo $\mathrm{N}^{\mathrm{o}} 13$, e se referem ao período de seis dias.

Durante a análise microscópica, os cortes correspondentes a este grupo revelaram alterações morfológicas celulares e teciduais em decorrência da ação da força aplicada. As regiões de tensão cervical e apical mostraram alargamento do espaço periodontal com presença de fibras colágenas oblíquas, estiradas e paralelas ao longo eixo, além de fibroblastos alongados, maduros formando fascículos (Figura 20). De permeio observou-se discreto infiltrado inflamatório mononuclear contendo linfócitos e macrófagos, vasos sangüíneos congestos e discreta hemorragia, além de pequenas e poucas áreas hialinas. O tecido ósseo apresentou a superfície da porção periodontal irregular, com cavidades de reabsorção inativas, sem linhas de reversão. Os osteoblastos apresentavam-se com disposição fasciculada e estavam justapostos à superfície. A porção medular apresentou tecido ósseo desorganizado, amplos espaços medulares e intenso infiltrado inflamatório mononuclear, com predomínio de linfócitos, além de células gigantes multinucleadas. A superfície cementária mostrouse regular com presença de cementóide com cementoblastos justapostos à superfície e ao acaso.

Os cortes microscópicos referentes revelaram que a espessura do ligamento periodontal no lado de compressão manteve-se diminuída, contendo fibroblastos maduros fusiformes e aleatórios em meio a fibras colágenas desorganizadas com disposição frouxa e aleatória constituindo um emaranhado (Figura 21). Pequenas e médias áreas hialinas foram identificadas, além de vasos sangüíneos congestos, focos hemorrágicos em meio a discreto infiltrado inflamatório mononuclear, com predomínio de linfócitos na área de compressão apical. O tecido ósseo apresentou superfície periodontal recortada com unidades de reabsorção constituídas por osteoclastos multinucleados presentes em lacunas e em franca atividade reabsortiva, sem linhas de reversão ou osteóide (Figura 22). Os osteoblastos eram esparsos e estavam distribuídos ao acaso. A porção endosteal não apresentou espaços medulares. A superfície cementária apresentou-se irregular com 
sítio de reabsorção. Nas outras regiões os cementoblastos estavam arranjados em paliçada e encontravam-se justapostos.

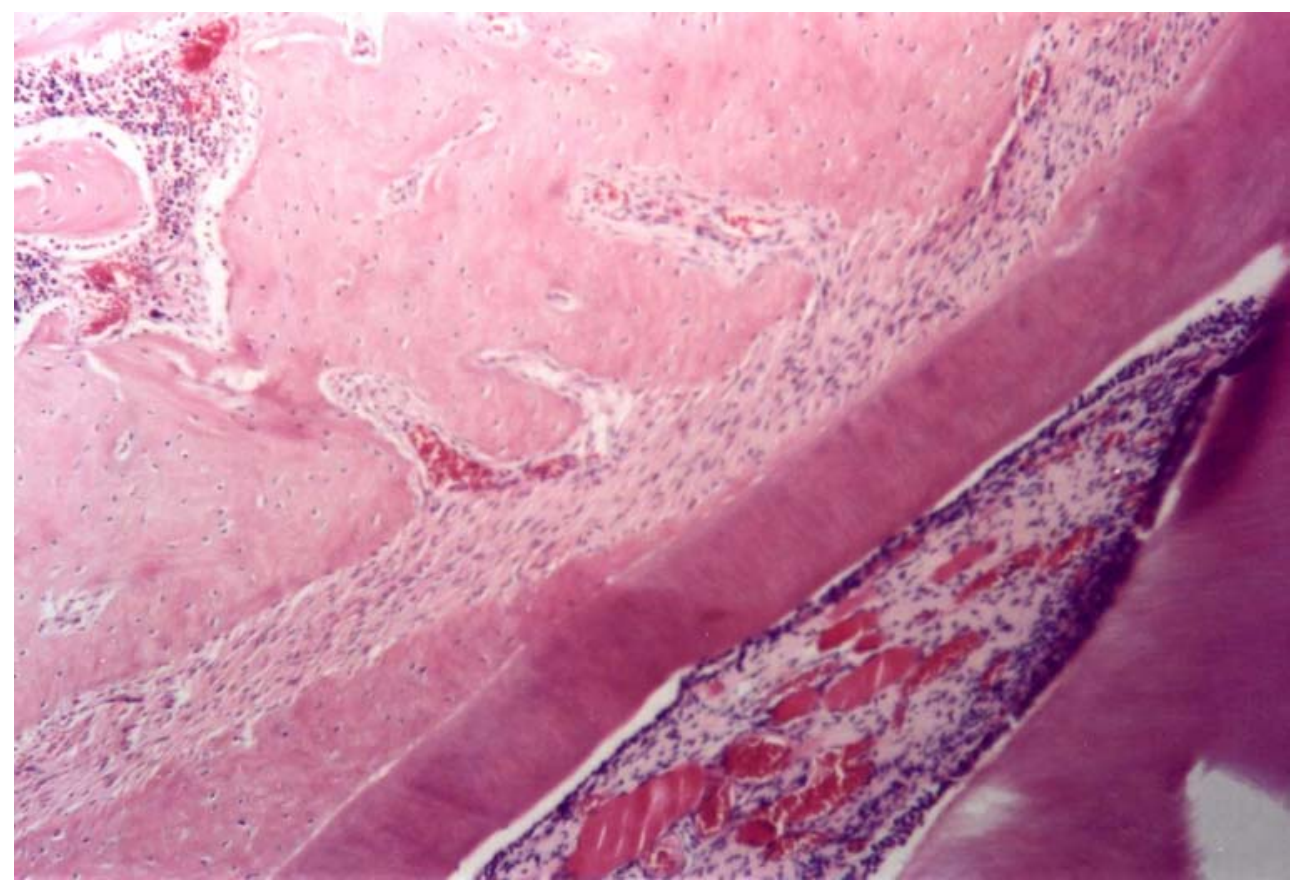

Figura 20 - Região cervical do lado de tensão da raiz mesiovestibular do Grupo 6. Notam-se ligamento periodontal ricamente celularizado, com fibras colágenas estiradas; superfícies óssea periodontal e cementária uniformes. $\mathrm{O}=$ osso; $\mathrm{L}=$ ligamento periodontal; $\mathrm{D}=$ dente (Coloração H. E.; Aumento Original - 100x) 


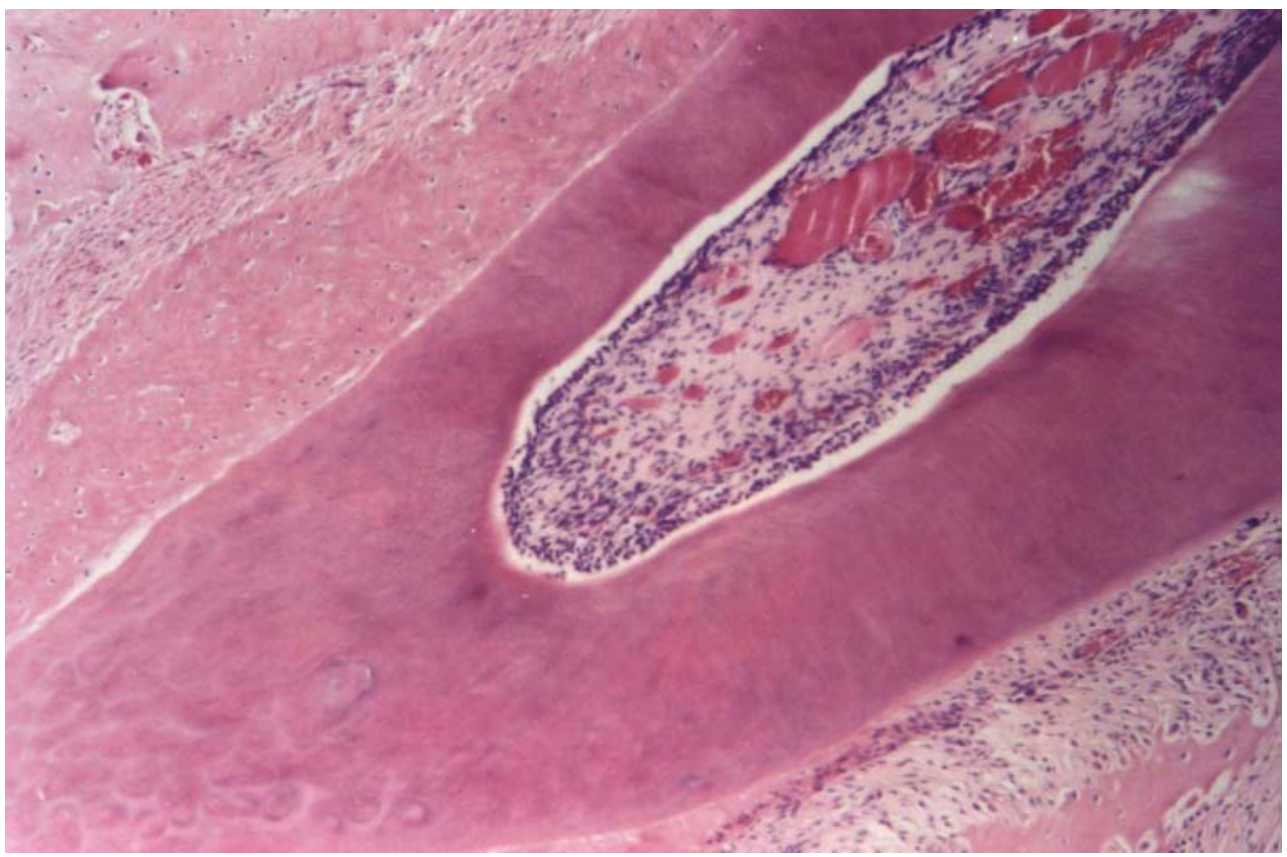

Figura 21 - Região cervical do lado de compressão da raiz mesiovestibular do Grupo 6. Notam-se ligamento periodontal ricamente celularizado; superfície óssea periodontal recortada com crista alveolar afilada; superfície cementária uniforme, revestida por cementoblastos. $\mathrm{O}=\mathrm{osso}$; $\mathrm{L}=$ ligamento periodontal; $\mathrm{D}=$ dente (Coloração H. E.; Aumento Original - 100x)

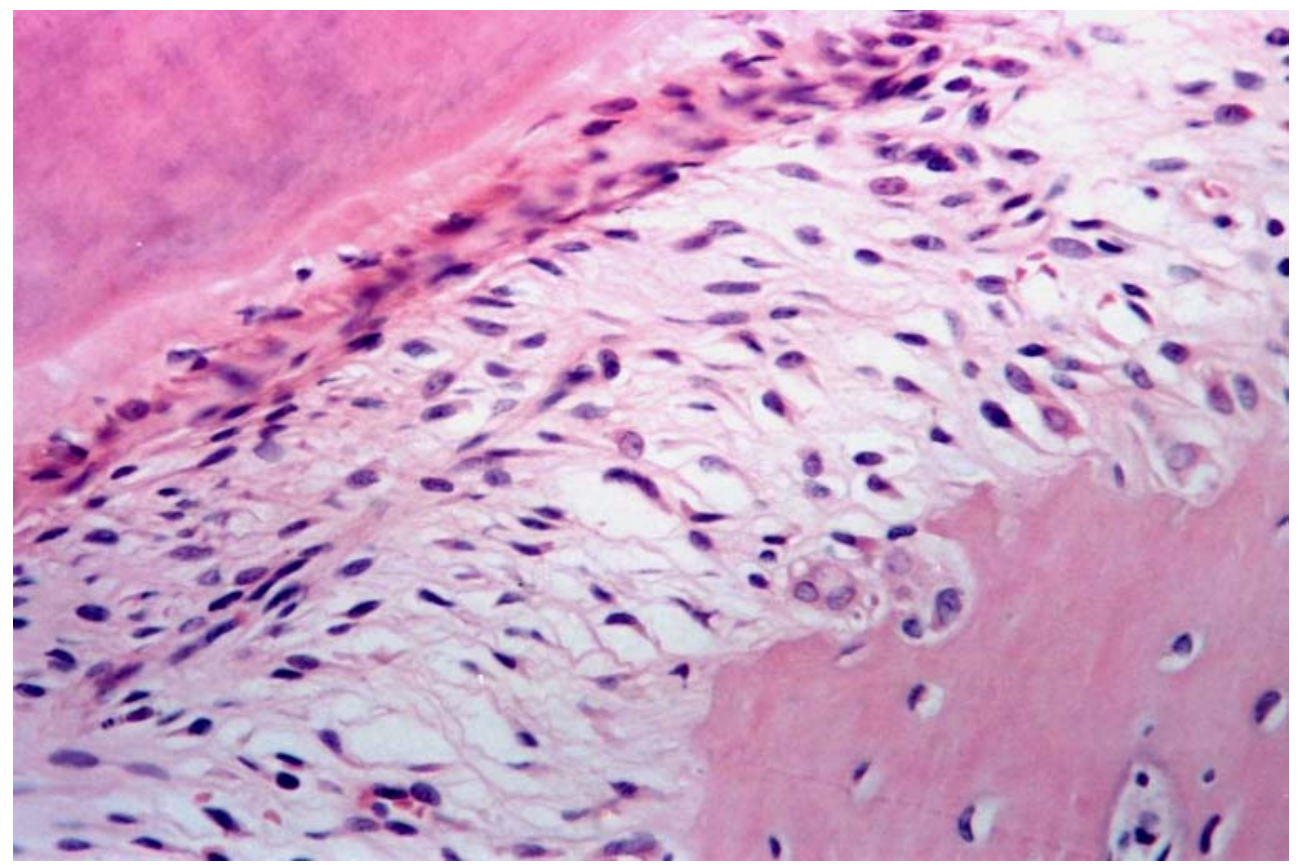

Figura 22 - Maior aumento da região de compressão do Grupo 6. Notam-se ligamento periodontal ricamente celularizado, com discretas áreas hialinas; superfície óssea periodontal com unidades de reabsorção; superfície cementária uniforme, revestida por cementoblastos. $\mathrm{O}=$ osso; $\mathrm{L}=$ ligamento periodontal; $\mathrm{D}$ = dente (Coloração H. E.; Aumento Original - 400x) 


\section{GRUPO 7}

Os dados morfológicos descritos a seguir podem ser visualizados nas figuras 23 e 24 e no capítulo Anexo $N^{0} 14$, e se referem ao período de sete dias.

Durante a análise microscópica, os cortes correspondentes a este grupo revelaram alterações morfológicas celulares e teciduais em decorrência da ação da força aplicada. Nas regiões de tensão cervical e apical do ligamento periodontal observou-se fibras colágenas oblíquas, paralelas, distendidas, esparsas, algumas dando a impressão de estarem rompidas de um dos lados de inserção, além de fibroblastos fusiformes e fasciculados (Figura 23). De permeio observou-se discreto infiltrado inflamatório mononuclear contendo linfócitos e macrófagos, vasos sangüíneos congestos e pontos focais de hemorragia, além de raras figuras de mitose. O tecido ósseo apresentou face periodontal irregular com cavidades reabsortivas inativas. Os osteoblastos localizavam-se justapostos à superfície, em sua maioria. Os osteoclastos ocasionais estavam distribuídos focalmente à distância. A porção endosteal apresentou-se bastante desorganizada, com amplos espaços medulares e intenso infiltrado inflamatório mononuclear com presença de múltiplas células gigantes em lacunas. A superfície cementária mostrou-se regular com presença de cementóide, revestida por cementoblastos com arranjo em paliçada, justapostos à superfície.

Na região de compressão cervical, o ligamento periodontal, com espessura aumentada, apresentou fibras colágenas desorganizadas, com disposição frouxa e fibroblastos em arranjo indefinido (Figura 24). Áreas de hialinização de tamanho médio foram identificadas, além da presença de moderado infiltrado inflamatório mononuclear, vasos sangüíneos congestos e discreta hemorragia. Na região de pressão apical, havia predomínio de linfócitos. O tecido ósseo, na superfície periodontal, continha unidades de reabsorção constituídas por osteoclastos multinucleados, presentes em lacunas, demonstrando uma atividade reabsortiva. Um dos animais apresentou irregularidade da crista óssea sem reabsorção. Os osteoblastos revestiam parcialmente a face óssea, estando dispostos sem organização, comumente justapostos à superfície. A superfície cementária apresentou, ocasionalmente, discretos sítios de reabsorção com cementoclastos presentes nas lacunas. Quanto ao revestimento por cementoblastos, ocorreu em toda a extensão restante da raiz que não apresentavam áreas de reabsorção e se encontravam justapostos à superfície. 


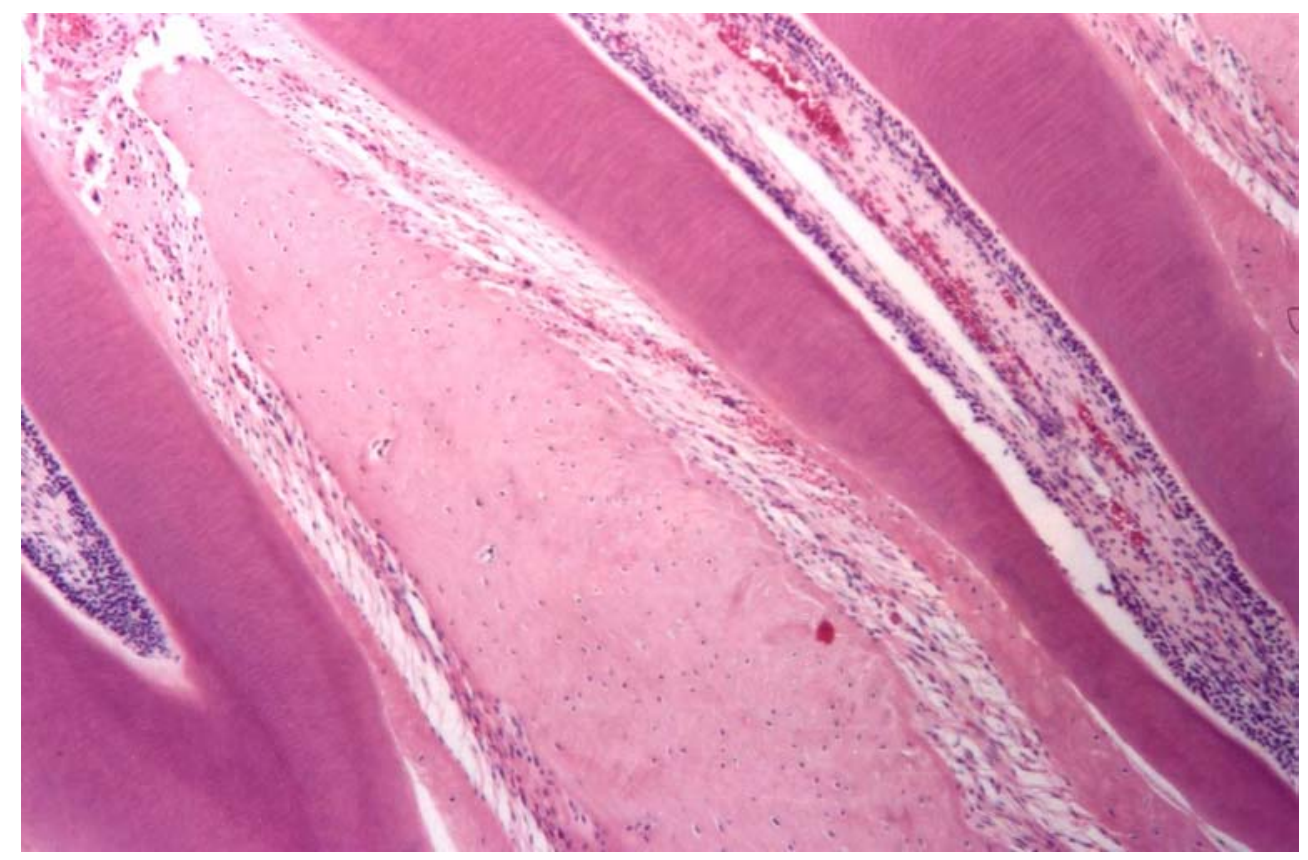

Figura 23 - Região cervical do lado de tensão da raiz mesiovestibular do Grupo 7 (seta). Notam-se ligamento periodontal ricamente celularizado, com fibras colágenas distendidas; superfície óssea periodontal discretamente ondulado; superfície cementária uniforme. $\mathrm{O}=$ osso; $\mathrm{L}=$ ligamento periodontal; $\mathrm{D}$ $=$ dente $($ Coloração H. E.; Aumento Original $-100 x)$

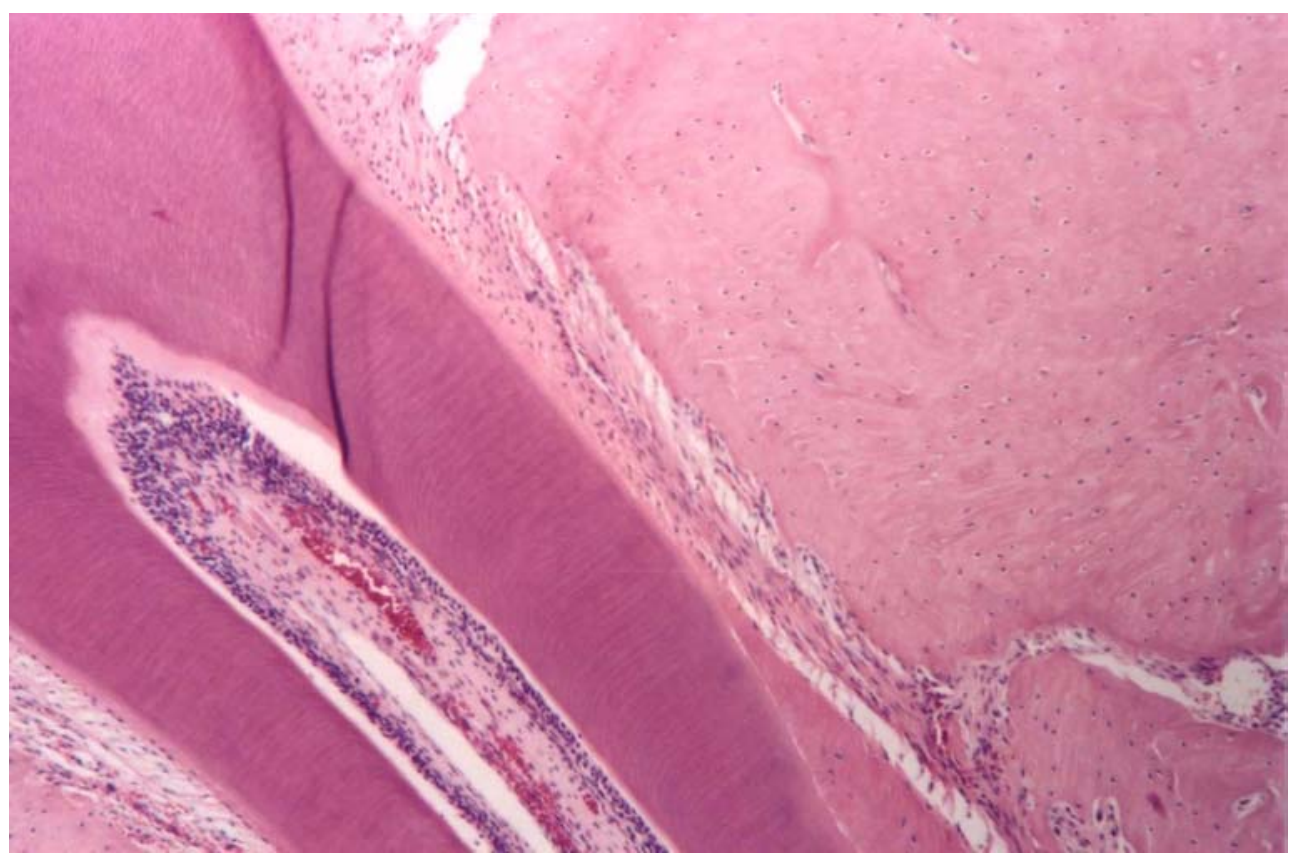

Figura 24 - Região cervical do lado de compressão da raiz mesiovestibular do Grupo 7. Notam-se ligamento periodontal com espessura diminuída, ricamente celularizado; superfície óssea periodontal com aspecto de normalidade; superfície cementária uniforme. $\mathrm{O}=$ osso; $\mathrm{L}=$ ligamento periodontal; $\mathrm{D}=$ dente (Coloração H. E.; Aumento Original - 100x) 


\section{DISCUSSÃO}

Nesta investigação, induziu-se movimentação dentária nos primeiros molares superiores de rato num período compreendido entre um e sete dias. Nossos achados demonstraram seqüência de eventos morfológicos ordenados cronologicamente associados à indução da movimentação, correspondendo à típica resposta biológica a forças mecânicas e a reações químicas promovidas pela movimentação dentária experimental aplicadas sobre os tecidos periodontais, concernentes aos estudos de HELLER; NANDA ${ }^{58}$, MACAPANPAN; WEINMANN; BRODIE ${ }^{101}$, REITAN ${ }^{132}$ e

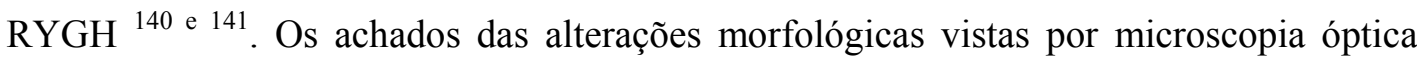
ocorridas durante este experimento foram concordes a estudos prévios (BRUDVIK; $\mathrm{RYGH}^{20 \mathrm{e} 21}$, PEREIRA ${ }^{127}, \mathrm{RYGH}^{139 \mathrm{e} 141}$ e VASCONCELOS ${ }^{184}$ ).

A movimentação dentária ocorre de maneira fisiológica ou induzida. Os estudos experimentais realizados sobre o tema apresentaram metodologia variada havendo concordância entre todos os métodos sob o ponto de vista biológico, incluindo este experimento. A ativação do processo biológico ocorre pelo sinal mecânico transferido fisicamente aos fluidos teciduais do ligamento periodontal em associação com moléculas de adesão entre células, matriz extracelular, osso alveolar e terminações nervosas, promovendo alteração na forma celular e na permeabilidade dos canais de íons, liberação de neuropeptídeos, vasodilatação capilar e extravasamento de leucócitos, junto com a geração e desencadeamento de potenciais de ação. As células do ligamento periodontal ativadas produzem citocinas e fatores de crescimento que modulam localmente a regulação do mecanismo de remodelação óssea (KVINNSLAND; HEYERAAS; ØFJORD ${ }^{89}$ e TOMS; GANNON; CARATI ${ }^{172}$ ), ou seja, a inflamação que ocorre durante a movimentação dentária, entre outros, apresenta, como resultado final a reabsorção e neoformação óssea (COOPER; SIMS ${ }^{34}$, MACAPANPAN; WEINMANN; BRODIE ${ }^{101}$, TOMS; GANNON; CARATI ${ }^{172}$, VANDEVSKA-RADUNOVIC et al. ${ }^{183} \mathrm{e}$ YOKOYA; SASAKI; SHIBASAKI ${ }^{200}$ ). Moléculas de tecido mineralizado liberadas no ligamento periodontal em conseqüência de danos por movimentação dentária induzida ou outros fatores patológicos, também funcionam como sinal quimiotático (SALO et al. ${ }^{143}$ ), sendo capazes de estimular a produção de mediadores pró-inflamatórios, com 
reconhecida atividade sobre os osteoclastos e macrófagos in vitro (LARA et al. ${ }^{91} \mathrm{e}$ SILVA $\left.{ }^{156}\right)$.

VERNA; ZAFFE; SICILIANI ${ }^{186}$ descreveram os eventos observados durante a movimentação dentária e observaram que de acordo com a intensidade de força não havia perda de massa óssea, pois a quantidade de osso reabsorvido estava em equilíbrio com a formação óssea. No entanto, se a pressão no ligamento periodontal se tornasse muito alta, criava-se a hialinização tecidual, com perda da arquitetura celular normal (ZAKI; VAN HUYSEN ${ }^{202}$ ), começando uma reabsorção indireta no osso medular circunjacente, isto é, à distância da área de compressão. Nesse caso não haveria deposição compensatória, e o equilíbrio entre reabsorção e aposição ficaria alterado, com o dente podendo sair do alvéolo causando deiscência. A quantidade de movimentação dentária induzida obtida depende da: interferência da oclusão do dente movimentado com os outros dentes (VERNA; ZAFFE; SICILIANI ${ }^{186}$ ), perfusão sangüínea (RYGH et al. ${ }^{142}$ ), presença de áreas hialinas (SHIRAZI et al. ${ }^{154}$ ) e fluxo sangüíneo aumentado em áreas com atividade osteoclástica (YAMAGUCHI; NANDA ${ }^{196}$ ).

A falta de resultados conclusivos a partir de investigações clínicas com relação ao significado da natureza, magnitude e duração das forças induzidas ilustra a dificuldade da padronização de um modelo experimental humano. O uso do modelo animal ajudaria a solucionar esses problemas embora surgisse um problema adicional relacionado à extrapolação de experimentos animais para o humano (WILLIAMS ${ }^{195} \mathrm{e}$ ENGSTROM; NOREN ${ }^{37}$ ). No entanto, AZUMA ${ }^{99}$, MACAPANPAN; WEINMANN; BRODIE ${ }^{101}$, REITAN ${ }^{130}$, REITAN; KVAM ${ }^{133}$, TRAN VAN; VIGNERY; BARON ${ }^{174}$ e VERNA; ZAFFE; SICILIANI ${ }^{186}$ encontraram no rato um modelo experimental que pode ser usado com sucesso para estudos sobre o osso humano. Autores como VIGNERY; BARON ${ }^{187}$ mostraram que a remodelação óssea alveolar em rato oferece um sistema ideal de observação da atividade celular durante os processos de modelação e remodelação óssea no estudo da movimentação dentária experimental, embora apresente grande variabilidade anatômica dentária (VERNA; ZAFFE; SICILIANI ${ }^{186}$ ), sendo necessária a comparação do lado controle com o lado de trabalho de todos os animais, conforme a metodologia aplicada no presente estudo. $\mathrm{O}$ osso alveolar de rato é um modelo ideal de estudo para analisar a remodelação óssea em condições normais ou 
experimentais por causa do perfeito equilíbrio entre reabsorção e formação e da alta taxa de turnover ósseo (ASHIZAWA; SAHARA ${ }^{3}$ e VIGNERY; BARON ${ }^{187}$ ).

A remodelação óssea, produzida como conseqüência da movimentação dentária induzida, foi descrita como um fenômeno contínuo que leva à reabsorção óssea no lado de compressão e deposição óssea no lado de tensão (PERINETTI et al. ${ }^{128} \mathrm{e}$ RYGH ${ }^{137}$ e 140 ). PERINETTI et al. ${ }^{128}$ relatam que sua fase inicial, ou seja, a atividade reabsortiva, ocorre entre três e cinco dias, seguida por uma fase reversa de cinco a sete dias, ocorrendo subseqüentemente a fase de deposição óssea entre sete e 14 dias. Sete dias após a movimentação dentária experimental pode-se observar deposição de osteóide sobre a superfície óssea alveolar, indicando o aumento da atividade osteogênica (VANDEVSKA-RADUNOVIC; KVINNSLAND; KVINNSLAND ${ }^{182}$ ). Esta teoria explicaria a escassa presença de osteóide em nossos estudos que teve tempo experimental máximo de sete dias, coincidindo o final do nosso experimento com o início do período de deposição óssea no lado de tensão, segundo esses autores.

A quantidade de movimentação induzida varia de acordo com a idade (BRIDGES; KING; MOHAMMED ${ }^{19}$ ). A resistência anatômica de ratos jovens é menor embora não haja relatos claros da possível relação entre densidade óssea e maturidade do animal. Em adultos a movimentação é mais lenta devido à diminuição da atividade proliferativa no ligamento periodontal e osso alveolar (VERNA; MELSEN ${ }^{185}$ ). Essa diferença afetaria a movimentação dentária em diferentes idades (BRIDGES; KING; MOHAMMED ${ }^{19}$ ), sendo a razão para termos trabalhado com animais adultos com mesmo tempo de vida. Independente da faixa etária sabe-se que sem a presença dos osteoclastos a movimentação dentária não aconteceria (TSAY; CHEN; OYEN ${ }^{175}$ ).

Nas pesquisas realizadas sobre a movimentação dentária induzida, os autores utilizaram diferentes tipos de aparelhos, que pode ser constituído de uma mola que une o primeiro molar superior ao incisivo superior de uma hemiarcada. Este foi o aparelho de escolha deste e de outros experimentos como os realizados por (HELLER; NANDA ${ }^{58}$, GOLDIE; KING ${ }^{51}$, KVINNSLAND; HEYERAAS; ØFJORD ${ }^{89}$, KVINNSLAND; KVINNSLAND ${ }^{88}$, NAGAI et al. ${ }^{117}$, PAVLIN et al. ${ }^{125}$, PEREIRA ${ }^{127}$, SHIRAZI et al. 154, TSAY; CHEN; OYEN ${ }^{175}$, VANDEVSKA-RADUNOVIC et al. ${ }^{183}$, VASCONCELOS ${ }^{184}$, VERNA; MELSEN ${ }^{185}$, VERNA; ZAFFE; SICILIANI ${ }^{186}$ e 
WILLIAMS ${ }^{195}$ ), ou de ambas as hemiarcadas (BRUDVIK; $\mathrm{RYGH}^{20}$ ), ou uma mola unindo o primeiro molar inferior ao incisivo inferior (VANDEVSKA-RADUNOVIC; KVINNSLAND; KVINNSLAND ${ }^{181}$ ), ou ainda utilizar bandas ortodônticas para separar os incisivos superiores (ENGSTROM NOREN ${ }^{37}$ e KYOMEN; TANNE ${ }^{90}$ ).

Muitos estudos experimentais utilizaram o método usado por WALDO e ROTHBLATT ${ }^{189}$ onde os molares são movimentados com a ação de bloco elástico inserido entre os molares (AZUMA ${ }^{9}$, HASHIMOTO et al. ${ }^{56}$, KOBAYASHI et al. ${ }^{83}$, MABUCHI; MATSUZAKA; SHIMONO ${ }^{100}$, MACAPANPAN; WEINMANN; BRODIE ${ }^{101}$, NAGAI et al. ${ }^{117}$, RODRIGUEZ et al. ${ }^{136}$, TALIC et al. ${ }^{166}$, TENSHIN et al. ${ }^{171} \mathrm{e}$ ZAKI; HUYSEN ${ }^{202}$ ). Em outros modelos conseguem constância durante cinco dias (BAUMRIND; BUCK ${ }^{14}$, MACAPANPAN; WEINMANN; BRODIE ${ }^{101}$ e WALDO e ROTHBLATT ${ }^{189}$ ). Neste experimento, optou-se pelo modelo proposto por HELLER; NANDA ${ }^{58}$, por manutenção dos níveis de força constante e decrescente num período de sete dias. O aparelho utilizado nos animais deste estudo é semelhante aos aparelhos utilizados por BRUDVIK; RYGH ${ }^{21}$, GOLDIE; KING ${ }^{51}$, PEREIRA ${ }^{127}$ e VASCONCELOS ${ }^{184}$, ou seja, não sofreu reativação durante o período experimental. A escolha deste modelo de estudo ocorreu por sua semelhança aos aparelhos fixos utilizados normalmente nas clínicas ortodônticas para correção das má-oclusões.

Há uma variabilidade entre os autores acerca da intensidade de força aplicada durante a movimentação dentária induzida. Forças iguais ou inferiores a $10 \mathrm{gf}$ foram usadas por KOHNO et al. ${ }^{84}$, KYOMEN; TANNE ${ }^{90}$ e PAVLIN et al. ${ }^{125}$, enquanto BRUDVIK; RYGH 20 e 21 , GAENGLER; MERTE ${ }^{47}$, GOLDIE; KING ${ }^{51}$, KVINNSLAND; HEYERAAS; ØFJORD ${ }^{89}$, KVINNSLAND; KVINNSLAND ${ }^{88}$, NAGAI et al. ${ }^{117}$, SHIRAZI et al. ${ }^{154}$, TSAY; CHEN; OYEN ${ }^{175}$, VANDEVSKARADUNOVIC et al. ${ }^{183}$ e WILLIAMS ${ }^{195}$ usaram 30, 40, 50gf e até $60 \mathrm{gf}$. A força aplicada sobre o primeiro molar afeta as propriedades mecânicas do ligamento periodontal (FUKUI ${ }^{44}$, KUFTINEC ${ }^{86}$ e VANDEVSKA-RADUNOVIC et al. ${ }^{183}$ ) e sua deformação reflete o início da movimentação dentária (HASHIMOTO et al. ${ }^{56}$ ) não existindo relação entre a magnitude de força inicial e neoformação óssea na parede alveolar do lado tensão durante a fase inicial da movimentação. No entanto, forças intensas produzem amplas áreas necróticas no ligamento periodontal que promove a 
demora na remodelação óssea no lado de pressão (ASHIZAWA; SAHARA ${ }^{3}$ ), daí a utilização nesta investigação de 50 gramas de força o que não provocou alterações morfológicas de grande amplitude, ou seja, forças biologicamente irreversíveis.

Os efeitos da movimentação dentária experimental no ligamento periodontal podem diferir de acordo com a posição radicular, amplitude e duração da força aplicada $\left(\mathrm{KI}{ }^{77}\right)$, sendo explicados pela propriedade viscoelástica do ligamento periodontal e pela alteração do osso alveolar (KOHNO et al. ${ }^{84}$ e YAMAGUCHI; NANDA ${ }^{196}$ ).

O tempo de duração utilizado na ativação do aparelho pode variar de um a 14 dias onde se observam produção de citocinas e conseqüente aumento da atividade celular com remodelação óssea e de fibras (BRUDVIK; RYGH ${ }^{20}$, GOLDIE; KING ${ }^{51}$, KVINNSLAND; HEYERAAS; ØFJORD ${ }^{89}$, KVINNSLAND; KVINNSLAND ${ }^{88}$, KYOMEN; TANNE ${ }^{90}$, NAGAI et al. ${ }^{117}$, RYGH ${ }^{138}$, SHIRAZI et al. ${ }^{154}$, TENSHIN et al. ${ }^{171}$ e VANDEVSKA-RADUNOVIC et al. ${ }^{183}$ ). Embora o significado biológico da morte celular por movimentação dentária induzida não esteja claro, é possível que a morte celular não esteja apenas envolvida no desaparecimento dos osteócitos, mas sim com a subseqüente reabsorção óssea. Após dois dias de aplicação de força, os osteócitos do lado de pressão exibem características ultra-estruturais de necrose apresentando aumento de mitocôndria, complexo de Golgi e retículo endoplasmático, com perda da membrana celular, distribuição citoplasmática de vesículas e alterações nucleares, iniciando o processo de hialinização tecidual, primeiro estádio do processo de reabsorção (HAMAYA et al. ${ }^{55}$ ). Nos estudos de KVINNSLAND; HEYERAAS; ØFJORD ${ }^{89}$, após cinco dias de movimentação induzida do primeiro molar ocorreu substancial aumento do fluxo sangüíneo no ligamento periodontal dos dentes do lado experimental quando comparados com o lado controle. Observou-se também que após sete dias de aplicação de força, lacunas de reabsorção surgiram nas zonas de compressão sobre as superfícies radiculares (ENGSTRÖM; GRANSTRÖM; THILANDER ${ }^{38}$ e VASCONCELOS ${ }^{184}$ ), concordando com este experimento que após sete dias observou-se que a superfície cementária continha, ocasionalmente, sítios de reabsorção com cementoclastos presentes em lacunas.

O ligamento periodontal é um tecido conjuntivo complexo, altamente vascularizado e celularizado que se interpõe entre dois tecidos mineralizados, o cemento 
e o osso alveolar. É importante mantenedor da posição dentária e distribui as forças mastigatórias sobre o osso alveolar. Sua principal função é regular e fixar o número de células para manutenção da homeostasia local (MABUCHI; MATSUZAKA; SHIMONO ${ }^{100}$, MURAMOTO; TAKANO; SOMA ${ }^{116}$ e RAGNARSSON; CARR; DANIEL ${ }^{129}$ ).

Muitos autores avaliaram as propriedades mecânicas do ligamento periodontal após aplicação de força experimental durante a movimentação induzida (MACAPANPAN; WEINMANN; BRODIE ${ }^{101}$, SHIRAZI et al. ${ }^{154}$, TSURUTA et al. ${ }^{177}$, VANDEVSKA-RADUNOVIC et al. ${ }^{183}$ e VIGNERY; BARON ${ }^{187}$ ) por meio de microscopia óptica (REITAN ${ }^{132}$ ) e/ ou eletrônica (LEW; SIMS; LEPPARD ${ }^{98}, \mathrm{RYGH}^{140}$ e TANG; SIMS ${ }^{167}$ ), e como regra geral, o lado de compressão do periodonto está associado à reabsorção óssea e o lado de tensão, à aposição. Embora existam estudos que demonstraram falha na teoria pressão-tensão, com os de VERNA; ZAFFE; SICILIANI ${ }^{186}$, eles observaram deposição óssea no lado de pressão de molares movimentados experimentalmente após 14 dias, como conseqüência de alterações na atividade celular do osso circunjacente, tanto no lado de compressão quanto no de tensão. Nos estádios iniciais da movimentação dentária a reabsorção óssea é maior que a deposição óssea, verificado em nossos resultados, mas na fase tardia, reabsorção e deposição tornam-se sincronizadas (PERINETTI et al. ${ }^{128}$ ). Sucessivos ciclos de reabsorção-formação no osso alveolar foram relatados por KIMURA et al. ${ }^{78}$ e VIGNERY; BARON ${ }^{187}$.

Observações feitas no ligamento periodontal indicaram que a inclinação mesial constante dos primeiros molares resulta em áreas de compressão periodontal, criando linhas de reversão que indicariam mudanças no padrão físiológico de movimentação do lado experimental durante a movimentação dentária. A margem reversa basofílica funciona como um indicador da movimentação dentária (HELLER; NANDA ${ }^{58}$ e WILLIAMS ${ }^{195}$ ) em nosso estudo verificou-se a presença destas linhas nos grupos experimentais 1, 2, 3 e 4 (Figuras 6, 7, 8, 9, 12, 13, 14 e 16).

No presente estudo, as alterações periodontais mais proeminentes ocorreram no sétimo dia, concordando com os estudos de OHKAWA ${ }^{121}$, RYGH ${ }^{137}$ e 138 , VANDEVSKA-RADUNOVIC; KVINNSLAND; KVINNSLAND ${ }^{182}$, VANDEVSKARADUNOVIC et al. ${ }^{183}$ e VASCONCELOS ${ }^{184}$, onde foi possível notar remodelação 
tecidual, aumento de fluxo sangüíneo, formação de elementos celulares e vasculares nos Grupos experimentais 3, 4, 5, 6 e 7 .

Ratos apresentam um número menor de restos epiteliais de Malassez no ligamento periodontal quando comparado ao homem ou outros animais (TALIC et al. $\left.{ }^{166}\right)$, o que explicaria sua escassa presença em meio aos resultados verificados durante análise microscópica deste e de outros experimentos (BRUDVIK; RYGH ${ }^{21}$, PEREIRA ${ }^{127}$ e VASCONCELOS ${ }^{184}$ ). Localizam-se, com maior freqüência, ao longo da raiz mesial do primeiro molar inferior e, na arcada superior do lado controle segundo o trabalho de WESSELINK; BEERTSEN ${ }^{193}$, sendo raramente vistos no periodonto do dente movimentado, corroborando aos nossos resultados. Provavelmente, eles sofreram necrose e degeneração (BRUDVIK; RYGH ${ }^{21}$ ). No entanto, na região dos outros molares do mesmo lado experimental podem ser visualizados (Figura 5). Estas células estão implicadas na síntese e liberação de citocinas e fatores de crescimento no tecido periodontal circunjacente provavelmente relacionada a manutenção do espaço periodontal (CONSOLARO ${ }^{33}$ e WESSELINK; BEERTSEN ${ }^{193}$ ).

Grandes quantidades de fibras colágenas velhas são perdidas no lado de compressão, particularmente no local de reabsorção (RYGH et al. ${ }^{142}$ ). Evidências mostram que os fibroblastos apresentam importante função na remodelação óssea durante a movimentação dentária mecânica por dissolução e reformação das fibras colágenas. Apresentando remodelação contínua o colágeno é sintetizado e degradado pelos fibroblastos periodontais em resposta ao estresse mecânico (ATSUMI et al. ${ }^{4}$, SU et al. ${ }^{162}$ e TEN CATE; DEPORTER; FREEMAN ${ }^{170}$ ).

Muitos autores verificaram que as áreas de tensão e compressão apresentam alterações circulatórias (ATTAL et al. ${ }^{8}$, KHOUW; GOLDHABER ${ }^{76}$, $\mathrm{LEW}^{97}$, RYGH et al. ${ }^{142}$, SIMS ${ }^{160}$ e TANG; SIMS ${ }^{167}$ ). O sistema vascular periodontal responde a estimulação mecânica com estreitamento da porção venosa e aumento do número de microvasos, sendo a intensidade da reação dependente do grau de distorção tecidual. As primeiras alterações circulatórias encontradas nesta pesquisa foram a congestão e discreta hemorragia com presença ocasional de infiltrado inflamatório polimorfonuclear, tipo neutrófilo, em meio ao influxo de infiltrado inflamatório mononuclear, corroborando aos experimentos de COOPER; SIMS ${ }^{34}$, LÓPEZ OTERO et al. ${ }^{99}$, MACAPANPAN; 
WEINMANN; BRODIE ${ }^{101}$ e RYGH ${ }^{140}$. Os capilares sangüíneos fenestrados conferem resistência às forças mastigatórias, no entanto a força inicialmente aplicada sobre os dentes resulta em compressão dos vasos sangüíneos com hemorragia, diminuição do fluxo e degeneração das células endoteliais (GAENGLER; MERTE ${ }^{47}$, GIANELLY ${ }^{50}$, $\mathrm{RYGH}^{137}$, RYGH et al. ${ }^{142}$ e YOKOYA; SASAKI; SHIBASAKI ${ }^{200}$ ). A região apical é ricamente vascularizada com muitos capilares entrelaçados, e dentre suas funções, também desempenham papel de amortecedor para as forças oclusais (TSUKADA et al. ${ }^{176}$ ), sendo talvez um dos motivos para serem vistos em maior quantidade nessa região (Figura 19).

A circulação periodontal apresenta diferentes alterações quando se comparam os tecidos comprimidos e tensionados (IMAMURA; NAKATA; NAKASIMA ${ }^{65}$ ). No lado tensionado, a área vascular permanece não afetada, ao passo que nas áreas de pressão o fluxo é quadruplicado (ATTAL et al. ${ }^{8}$ e TANG; SIMS ${ }^{167}$ ). RYGH ${ }^{137}$ e RYGH et al. ${ }^{142}$ verificaram que nas primeiras 24 horas após a aplicação de força ocorre uma obliteração parcial ou total dos vasos, e no segundo e terceiro dias observa-se desintegração das paredes vasculares e degradação de hemácias. Os processos proliferativos dos elementos celulares e vasculares ocorreram após o sétimo dia, explicando a não identificação desse fenômeno nesta amostra. No lado de tensão, a atividade vascular foi descrita como moderada no primeiro dia, e intensa no sétimo dia, com aumento do número de vasos sangüíneos (KINDLOVÁ; MATĚNA ${ }^{80}$, SELLISETH; SELVIG ${ }^{151}$ e YOKOYA; SASAKI; SHIBASAKI ${ }^{200}$ ). O aumento do número de capilares e vênulas e diminuição das arteríolas nos locais de pressão e tensão é atribuído ao estímulo mecânico gerado no tecido estimulado por indução de força (ATTAL et al. ${ }^{8}$, COOPER; SIMS ${ }^{34}$ e VANDEVSKA-RADUNOVIC; KVINNSLAND; KVINNSLAND $\left.{ }^{182}\right)$.

O mecanismo neurogênico apresenta importante função na regulação de fluxo sangüíneo durante a movimentação dentária induzida (KVINNSLAND; KVINNSLAND ${ }^{88}$, VANDEVSKA-RADUNOVIC; KVINNSLAND; KVINNSLAND ${ }^{181}$ ). Os neurônios sensoriais peptidérgicos iniciam e medeiam a inflamação neurogênica em diferentes tecidos, estimulando a vasodilatação, acompanhada de aumento do fluxo sangüíneo e extravasamento de plasma (VANDEVSKA-RADUNOVIC; KVINNSLAND; 
KVINNSLAND ${ }^{181}$ ). Estudos revelaram que altos conteúdos de cálcio encontram-se ligados a proteínas nos axônios terminais de Ruffini indicando que o cálcio possui importante função na transdução mecano-elétrica (HIROSHIMA et al. ${ }^{60}$, NAKAKURAOHSHIMA et al. ${ }^{118}$ e WAKISAKA et al. ${ }^{188}$ ).

Há poucos estudos sobre as propriedades fisiológicas dos mecanorreceptores do periodonto de dentes movimentados experimentalmente, mas acredita-se que eles estejam conectados a nervos de maior calibre, cujas propriedades fisiológicas são rapidamente alteradas, sugerindo que os mecanorreceptores respondem precocemente à movimentação dentária induzida (OGAWA et al. ${ }^{120}$ ). Em três dias de movimentação dentária ocorre aumento da densidade das fibras nervosas. As alterações mais proeminentes, como a sensação dolorosa, ocorrem sete dias após o início da movimentação. Os nervos sensoriais apresentam importância nos vários estádios da remodelação tecidual relacionados à movimentação dentária, devido à recepção e propagação do estímulo mecânico (VANDEVSKA-RADUNOVIC; KVINNSLAND; KVINNSLAND ${ }^{182}$ e VANDEVSKA-RADUNOVIC et al. ${ }^{183}$ ), ocorrendo mais intensamente em 14 dias (VANDEVSKA-RADUNOVIC; KVINNSLAND; KVINNSLAND ${ }^{182}$ ) devido à propriedade plástica das terminações nervosas. A proteína GAP-43 é a molécula responsável pelo desenvolvimento e regeneração neural após a movimentação dentária experimental (ATSUMI et al. ${ }^{4}$, ATSUMI et al. ${ }^{5}$, HIROSHIMA et al. ${ }^{60}$, KOBAYASHI et al. ${ }^{82}$, KVINNSLAND; KVINNSLAND ${ }^{88}$, MAEDA; BYERS ${ }^{102}$, MAEDA et al. ${ }^{103}$, WAKISAKA et al. ${ }^{188}$, YAMAMOTO et al. ${ }^{197}$ e YOUN et al. ${ }^{201}$ ). No ligamento periodontal do molar de rato, a expressão da GAP-43 é vista no axoplasma das terminações de Ruffini e durante a movimentação dentária experimental ocorre desaparecimento parcial da bainha de Schwann (KOBAYASHI et al. ${ }^{82}$ e MURAMOTO; TAKANO; SOMA ${ }^{116}$ ). A expressão transitória da proteína GAP-43 nas células de Schwann terminais também ocorrem mediante injúria nervosa, implicando numa associação da expressão dessa proteína com a célula de Schwann durante a regeneração. Esses dados sugerem que a bainha de Schwann apresenta importante função na manutenção da morfologia bem como na função das terminações nervosas de Ruffini periodontais (MURAMOTO; TAKANO; SOMA ${ }^{116}$ e YOUN et al. ${ }^{201}$ ). 
Muitos estudos aumentaram a eficácia da movimentação dentária por estimular o aumento do número de osteoclastos no ligamento periodontal. A administração local de osteocalcina em rato estimula seu aparecimento sobre a parede alveolar no lado de pressão, resultando em aumento do deslocamento dentário (CHENU et al. ${ }^{29}$, HASHIMOTO et al. ${ }^{56}$ e KOBAYASHI et al. ${ }^{83}$ ). A injeção de VEGF acelera o processo de diferenciação osteoclástica (KAKU et al. ${ }^{75}$ ) e a administração local de prostaglandina $E_{2}$ resulta em aceleração da movimentação por indução da reabsorção óssea, pois é um importante mediador do estresse mecânico (BOEKENOOGEN et al. ${ }^{17}$, KOBAYASHI et al. ${ }^{83}$, LEIKER et al. ${ }^{93}$, SANDY; FARNDALE; MEIKLE ${ }^{145} \mathrm{e}$ YAMASAKI; MIURA; SUDA ${ }^{199}$ ).

O VEGF é expresso nos osteoblastos do lado tensão do periodonto que foram submetidos à movimentação experimental, sugerindo que ele pode participar da regulação do metabolismo ósseo e do seu reparo durante a movimentação dentária induzida (KOHNO et al. ${ }^{84}$ ). Este fator de crescimento pode participar da função de remoção de tecido necrótico por acelerar a angiogênese na área de compressão (KOHNO et al. $\left.{ }^{84}\right)$.

A variabilidade na quantidade de movimentação dentária induzida está relacionada às áreas de hialinização (TENSHIN et al. ${ }^{171}$ e VERNA; ZAFFE; SICILIANI ${ }^{186}$ ). Os estudos de REITAN; KVAM ${ }^{133}$ foram concernentes a este experimento no que diz respeito a presença de hialinização no lado de compressão. Essas áreas surgem em tempos variáveis, conforme a intensidade da força aplicada. MACAPANPAN; WEINMANN; BRODIE ${ }^{101}$ relataram que de três a seis horas após a aplicação de força sobre o dente, ocorre a hialinização no lado de pressão (YOKOYA; SASAKI; SHIBASAKI ${ }^{200}$ ). No experimento de BRUDVIK; RYGH ${ }^{21}$, as áreas hialinas surgiram com um dia de movimentação, neste experimento, com dois dias e nos estudos de PEREIRA ${ }^{127}$, com três dias. Durante a hialinização o dano tecidual causado no ligamento periodontal altera o microambiente bioquimicamente. Esse processo pode ser dividido nas fases de degeneração, eliminação e restabelecimento e é favorável à indução da reabsorção do tecido duro $\left(\mathrm{RYGH}{ }^{141}\right)$. Esse tecido hialinizado é completamente removido após 14 dias. Evidências apresentadas por RYGH ${ }^{139}$ mostraram que a remoção do tecido periodontal é iniciada por células semelhantes a macrófagos e fibroblastos 
(BRUDVIK; RYGH ${ }^{21}$ e VANDEVSKA-RADUNOVIC; KVINNSLAND; KVINNSLAND ${ }^{182}$ ). As superfícies radiculares adjacentes às áreas hialinas apresentavam lacunas de reabsorção nas zonas de compressão periodontal com atividade degenerativa e reabsorção óssea alveolar (ENGSTRÖM; GRANSTRÖM; THILANDER ${ }^{38}$ ), concordando com este estudo (Figuras 14 e 18).

Remodelação é caracterizada pela presença de BMUs, em ambos os lados, pressão e tensão (Figura 14) (VERNA; ZAFFE; SICILIANI ${ }^{186}$ ). A formação de osteóide é uma observação essencial demonstrada após estímulo mecânico (PAVLIN et al. ${ }^{125}$ ). Os nervos peptidérgicos atuam como moduladores da atividade óssea aumentando a formação de tecido osteóide durante a movimentação dentária (VANDEVSKARADUNOVIC; KVINNSLAND; KVINNSLAND ${ }^{182}$ ). O estímulo mecânico osteogênico aumenta a expressão gênica do colágeno tipo I nos osteoblastos periodontais, uma vez que se observa deposição de matriz óssea por diferenciação de células precursoras em osteoblastos maduros (PAVLIN et al. ${ }^{125}$ ).

A remodelação do tecido periodontal acompanha a reabsorção radicular ainda que a concavidade da lacuna de reabsorção não esteja preenchida, o que explica a necessidade da reparação do cemento acelular. Observações feitas por REITAN ${ }^{132}$ mostraram que a reabsorção radicular é comum durante a movimentação dentária induzida. As fibras celulares intrínsecas do cemento podem preencher o defeito reabsortivo em um razoável período de tempo. No caso do rato, as fibras extrínsecas acelulares do cemento coordenam o reparo do defeito reabsortivo rapidamente, porque os cementoblastos de rato apresentam alto nível de atividade, admitindo que considerável parte do ápice radicular desenvolva-se mais rapidamente nos ratos quando comparados aos humanos (KIMURA et al. ${ }^{78}$ ). Neste estudo, observou-se uma única área de reabsorção radicular que corresponde a região de tensão apical de um dos animais do Grupo 4, neste caso provavelmente ela não está relacionada com a movimentação e foi um achado ocasional.

A reabsorção óssea é um essencial componente da modelação e remodelação óssea durante o crescimento ósseo (MIDGETT; SHAYE; FRUGE ${ }^{113}$, SALO et al. ${ }^{143}$ e YAMASAKI; MIURA; SUDA ${ }^{199}$ ). Acompanhando a movimentação dentária induzida, os osteoclastos do osso alveolar são estimulados a reabsorver osso das paredes alveolares 
comprimidas associadas à movimentação dentária. Os osteoblastos, macrófagos e fibroblastos desempenham importante função no controle da atividade dos osteoclastos envolvidos na reabsorção (SU et al. ${ }^{162}$ ). Os produtos da degradação óssea são endocitados pelos clastos, transportados em vesículas e liberados no espaço extracelular da superfície oposta continuamente (SALO et al. ${ }^{143}$ e SILVA ${ }^{156}$ ). O dano tecidual causado durante a movimentação dentária experimental é um pré-requisito à estimulação da reabsorção óssea, visto que há uma correlação positiva entre magnitude da força, dano tecidual e grau de reabsorção (RYGH et al. ${ }^{142}$ ).

A renovação e morte celular parecem ser contraditórias, mas estão ligadas no tecido ósseo. Após o osteoclasto parar de reabsorver osso, sofre morte por apoptose e é rapidamente fagocitado no início da fase reversa. Conforme os osteoblastos completam a síntese de matriz óssea eles vão sendo comprimidos, tornando-se células de revestimento, a maioria morre por apoptose ou revestem a superfície que sofreu erosão da reabsorção. Os osteoblastos que foram deixados para trás nas lacunas tornam-se osteócitos e mantêm comunicação com os osteoblastos da superfície e com as células de revestimento. O sistema osteócito-canalicular forma uma rede sincicial com área superficial e esta rede provavelmente se torna o receptor que detecta pressões externas dos cristais de hidroxiapatita para enviar mensagens que iniciarão a ativação da remodelação óssea (JUNQUEIRA et al. ${ }^{73}$ ).

O cemento é menos vulnerável à reabsorção que o osso, embora ambos apresentem algumas similaridades como o fato da porção celular estar em maior grau que a acelular. Além disso, a resistência da superfície radicular cementária resulta da propriedade dos cementoblastos não apresentarem, na sua membrana celular, receptores aos mediadores estimuladores da reabsorção óssea (CONSOLARO ${ }^{33}$ ), explicando a ausência quase total de áreas de reabsorção cementária neste estudo, concordando com PEREIRA ${ }^{127}$. Sua composição química é semelhante ao osso, exceto pelo componente fluoretado. Também existem diferenças anatômicas, pois o osso é amplamente vascularizado enquanto o cemento é destituído de vasos sangüíneos. As anastomoses e os canalículos dentro do cemento entre os cementócitos e o ligamento periodontal são inadequados para garantir a vitalidade dos cementócitos nas camadas profundas (RYGH $\left.{ }^{141}\right)$. Os tecidos dentários são depósitos permanentes de sais minerais enquanto que o 
tecido ósseo funciona como um reservatório. $\mathrm{O}$ cemento é depositado continuamente ao longo da vida enquanto que o osso é constantemente remodelado (REITAN ${ }^{132}$ ). Na superfície óssea alveolar, como em qualquer superfície óssea, os clastos estão presentes como parte do constituinte celular normal, não sendo o caso do cemento. A alta taxa de remodelação óssea faz com que as fibras colágenas perto do osso sejam mais imaturas quando comparadas com as fibras adjacentes ao cemento, sugerindo que tal fato possa garantir uma maior resistência do cemento à reabsorção. $\mathrm{O}$ pré-cemento nãomineralizado ou cementóide também funciona como um fator que confere maior resistência a reabsorção $\left(\mathrm{RYGH}^{141}\right)$. Uma vez que a lacuna de reabsorção foi instalada o cemento é reabsorvido posteriormente. Por continuidade da aplicação de força o processo de reabsorção continua até que todo tecido hialinizado seja eliminado. Se a força aplicada é descontínua ou diminui a lacuna de reabsorção é reparada (REITAN ${ }^{132}$ e RYGH $^{141}$ ).

A remoção inicial do pré-cemento é realizada por células não clásticas mononucleadas caracterizando um evento precoce da reabsorção. O desaparecimento tecidual das células e fibras do ligamento periodontal e do pré-cemento parece ocorrer por fagocitose a partir de macrófagos e células semelhantes a fibroblastos. A remoção tardia de tecido conjuntivo não-mineralizado parece ser realizado por atividade enzimática, possivelmente colagenase (BRUDVIK; RYGH ${ }^{21}$ ). Células TRAP-positivas ao redor da área de reabsorção radicular sugerem que uma relação com osteoclasto (BRUDVIK; RYGH ${ }^{21}$ e HUGHES; KING ${ }^{62}$ ). A perda do pré-cemento exporia o cemento, ocasionando um atrativo para os clastos e seus precursores. Essa seria a razão para a existência de células multinucleadas à distância da superfície radicular após 24 horas e sobre a superfície radicular após quatro a cinco dias. Esses achados correspondem a observações de BRUDVIK; RYGH ${ }^{21}$ de que as primeiras células que invadem a superfície radicular na periferia do tecido hialinizado são células mononucleadas negativas para TRAP, em outras palavras, não são clastos nem seus precursores. Conforme os estudos de NAKANE; KAMEYAMA ${ }^{119}$ uma delicada camada de cementóide foi depositada por cementoblastos nos grupos 4, 5, 6 e 7 .

A reabsorção radicular é um fenômeno transitório que ocorre na periferia do tecido necrótico hialinizado (BRUDVIK; RYGH ${ }^{21}$ e HUGHES; KING ${ }^{62}$ ) e não exibe severa inflamação (KIMURA et al. ${ }^{78}$ ). A reabsorção radicular está relacionada à 
presença de áreas hialinas associadas a forças ortodônticas descritas inicialmente por SANDSTEDT ${ }^{144}$ apud HELLER; NANDA ${ }^{58}$ e posteriormente pelos estudos microscópicos de RYGH ${ }^{139}$ e WILLIAMS ${ }^{195}$. Estas áreas aparecem em função da destruição tecidual local envolvendo, inclusive os cementoblastos superficiais e foram observadas em pouca quantidade em nossos espécimes, explicando a ausência de reabsorção radicular neste estudo. BRUDVIK; RYGH ${ }^{21}$ especularam que o ligamento periodontal e o cemento apresentavam potente inibidor de colágeno que protege a raiz contra a reabsorção, mas sabe-se que essa proteção é resultante de receptores moleculares aos mediadores químicos da reabsorção óssea (CONSOLARO ${ }^{33}$ ).

As cavidades reabsorvidas na superfície radicular ocorreram no mesmo momento da remoção do tecido hialinizado pelos clastos nos estudos de BRUDVIK; $\mathrm{RYGH}^{20}$, REITAN ${ }^{132}$ e RYGH ${ }^{139}$, além de observar que as áreas de irregularidade cementária aumentavam ao longo do experimento, conforme nossos estudos. NAKANE; KAMEYAMA ${ }^{119}$ observaram células gigantes multinucleadas no ligamento periodontal justapostas ou dentro de lacunas de reabsorção na superfície óssea, concordando com nossos achados. Algumas vezes viram-se as células gigantes em fase que parecia inativa, isto é, se encontravam no meio do ligamento de forma arredondada, sem apresentarem seu aspecto de borda em escova imediatamente antes ou após a reabsorção. 
6 CONCLUSÃO 


\section{CONCLUSÃO}

Com base nas constatações e levando-se em consideração a metodologia utilizada, concluiu-se que:

1 - As alterações morfológicas celulares e teciduais no periodonto de sustentação dos dentes submetidos a estresse mecânico sofreram variações morfológicas que foram intensificadas gradualmente à medida que avançava o período experimental, sem, no entanto, ocorrer reabsorção dentária;

2 -O tempo ideal de movimentação dentária induzida em ratos compreende o período onde há um equilíbrio entre a força aplicada e as alterações morfológicas não destrutivas irreversivelmente obtidas. Neste experimento, o quinto dia após a aplicação da força. 


\section{REFERÊNCIAS BIBLIOGRÁFICAS"}

1 - ALVAREZ, J.I. et al. Osteoclast precursors circulate in Avian blood. Calcif Tissue Int, v.51, n.1, p. 48-53, July 1992.

2 - ASAHITO, T. et al. Postnatal expression of calretinin-immunoreactivity in periodontal Ruffini endings in the rat incisor: a comparasion with protein gene product 9.5 (PGP 9.5) - immunoreactivity. Arch Histol Cytol, v.6, n.1, p.5769, Mar. 1999.

3 - $\quad$ ASHIZAWA, Y.; SAHARA, N. Quantitative evaluation of newly formed bone in the alveolar wall surrounding the root during the initial stage of experimental tooth movement in the rat. Arch Oral Biol, v.43, n.6, p.473-84, June 1998.

4 - ATSUMI, Y. et al. Altered distribuition of Schwann cells in the periodontal ligament of the rat incisor following resection of the inferior alveolar nerve: an immunohistochemical study on S-100 proteins. Brain Res, v.849, n.1-2, p. 18795, Dec. 1999.

5 - ATSUMI, Y. et al. Heterogeneous localizations of Trk B among individual periodontal Ruffini endings in the rat incisor. Arch Histol Cytol, v.62, n.5, p.435-40, Dec. 1999.

6 - ATSUMI, Y. et al. Effects of different types of injury to the inferior alveolar nerve on the behavior of Schwann cells during the regeneration of periodontal nerve fibers of rat incisor. Arch Histol Cytol, v.63, n.1, p.43-54, Mar. 2000.

7 - ATSUMI, Y. et al. Effects of neonatal injury of the alveolar nerve on the development and regeneration of periodontal nerve fibers in the rat incisor. Brain Res, v.871, n.2, p.201-9, July 2000.

8 - ATTAL, U. et al. Histomorphometric study of the periodontal vasculature during and after experimental tipping of the rat incisor. Arch Oral Biol, v.46, n.10, p. 891-900, Oct. 2001.

9 - AZUMA, M. Study on histologic changes of periodontal membrane incident to experimental tooth movement. Bull Tokyo Med Dent Univ, v.17, n.2, p.14978, June 1970.

10 - BAAB, D.A.; ÖBERG, P.Á.; HOLLOWAY, G.A. Gingival blood flow measured with a laser doppler flowmeter. J Periodont Res, v.21, n.1, p.73-85, Jan. 1986.

11 - BARON, R.; TROSS, R.; VIGNERY, A. Evidence of sequential remodeling in rat trabecular bone: morphology, dynamic histomorphometry, and changes during skeletal maturation. Anat Rec, v.208, n.1, p.137-45, Jan. 1984.

12 - BARON, R. et al. Kinetic and cytochemical identification of osteoclasts precursors and their differentiation into multinucleated osteoclasts. Am J Pathol, v.122, n.2, p.363-78, Feb. 1986.

13 - BATISTA, A.C. et al. Nitric oxide synthesis and severity of human periodontal disease. Oral Dis, v.8, n.5, p.254-60, Sept. 2002.

\footnotetext{
* Normas do Serviço de Biblioteca e Documentação da FOB-USP, 2003.
} 
14 - BAUMRIND, S.; BUCK, D.L. Rate changes in cell replication and protein synthesis in the periodontal ligament incident to tooth movement. Am J Orthod, v.57, n.2, p.109-31, Feb. 1970.

15 - BERNICK, S. Vascular supply to the development teeth of rats. Anat Rec, v.137, n.7, p. 141-51, May/Aug. 1960.

16 - BERNICK, S. Age changes in the blood supply to molar teeth of rats. Anat Rec, v.144, n.3, p. 265-74, Nov. 1962.

17 - BOEKENOOGEN, D.I. et al. The effects of exogenous prostaglandin $E_{2}$ on root resorption in rats. Am J Orthod Dentofac Orthop, v.109, n.3, p.277-86, Mar. 1996.

18 - BREATHNACH, S.M. et al. Amyloid P component is located on elastic fibre microfibrils in normal human tissue. Nature, v.293, n. 5834, p. 652-4, Oct. 1981.

19 - BRIDGES, T.; KING, G.; MOHAMMED, A. The effect of age on tooth movement and mineral density in the alveolar tissues of the rat. Am J Orthod Dentofac Orthop, v.93, n.3, p.245-50, Mar. 1988.

20 - BRUDVIK, P.; RYGH, P. Root resprtion after local injection of prostaglandin $\mathrm{E}_{2}$ during experimental tooth movement. Europ J Orthod, v.13, n.4, p.255-63, Aug. 1991.

21 - BRUDVIK, P.; RYGH, P. Non-clast cells start orthodontic root resorption in the periphery of hyalinized zones. Eurp J Orthod, v.15, n.6, p.467-80, Dec. 1993.

22 - BUTLER, W.T. Dentin matrix proteins. Eur J Oral Sci, v.106, p.204-10, Jan. 1998. Supplement 1.

23 - BYERS, M.R.; HOLLAND, G.R. Trigeminal nerve enddings in gingiva, junctional epithelium and periodontal ligament of rat molars as demonstrated by autoradiography. Anat Rec, v.188, n.4, p.509-24, Aug. 1977.

24 - CARMICHAEL, G.G. Observations with the light microscope on the distribuition and connexions of the oxytalan fibre of the lower jaw of the mouse. Arch Oral Biol, v.13, n.7, p.765-72, July 1968.

25 - CARRANZA, F.A. et al. A study of periodontal vascularization in different laboratory animals. J Periodont Res, v.1, n.2, p.120-8, 1966.

26 - CASTELLI, W.A. Vascular architecture of the human adult mandible. J Dent Res, v.42, n.3, p. 786-92, May/ June 1963.

27 - CASTELLI, W.A.; DEMPSTER, W. T. The periodontal vasculature and its responses to experimental pressures. J Amer Dent Assoc, v.70, n.4, p. 890-905, Apr. 1965.

28 - CHANTAWIBOONCHAI, P. et al. Confocal laser scanning-microscopic observations on the three-dimensional distribuition of oxytalan fibres in mouse periodontal ligament. Arch Oral Biol, v.43, n.10, p.811-17, Oct. 1998.

29 - CHENU, C. et al. Osteocalcin induces chemotaxis, secretion of matrix proteins, and calcium-mediated intracellular signaling in human osteoclast-like cells. J Cell Biol, v.127, n.4, p.1149-58, Nov. 1994. 
30 - CHINTAKANON, K.; SIMS, M.R. Ultrastructural morphology of vascular endothelial junction in periodontal ligament. Austr Dent J, v.39, n.2, p. 105-10, Apr. 1994.

31 - CHO, M.; GARANT, P.R. Development and general structure of the periodontium. Periodontol 2000, v.24, n.1, p.9-27, Oct. 2000.

32 - COHEN, L. Further studies into the vascular architecture if the mandible. J Dent Res, v.39, n.5, p.936-46, Sept./Oct. 1960.

33 - CONSOLARO, A. Reabsorções dentárias nas especialidades clínicas. Maringá: Dental Press, 2002.

34 - COOPER, S.M.; SIMS, M.R. Evidence of acute inflammation in the periodontal ligament subsequent a orthodontic tooth movement in rats. Austr Orthod J, v.11, n.2, p. 107-09, Oct. 1989.

35 - DUCY, P. et al. Icreased bone formation in osteocalcin-deficient mice. Nature, v.382, n.6590, p. 448-52, Aug. 1996.

36 - EL-AGROUDI, M.A.; SELLISETH, N.J.; SELVIG, K.A. Microvascular system of the rat incisor enamel organ. A scanning electron microscopic study of vascular corrosion casts. Eur J Oral Sci, v.106, n.6, p.1013-21, Dec. 1998. Errata: Eur J Oral Sci, v.107, n.1, p.7, Feb. 1999.

37 - ENGSTROM, C.; NOREN, J.G. Effects of orthondontic force on enamel formation in normal and hypocalcemic rats. J Oral Pathol, v.15, n.2, p.78-82, Feb. 1986.

38 - ENGSTRÖM, C.; GRANSTRÖM, G.; THILANDER, B. Effect of orthodontic force on periodontal tissue metabolism. A histologic and biochemical study in normal and hypocalcemic young rats. Am J Orthod Dentofac Orthop, v.93, n.6, p.486-95, June 1988.

39 - EVERTS, V. et al. Type VI collagen is associated with microfibrils and oxytalan fibers in the extravellular matrix of periodontium, mesenterium and periosteum. J Periodont Res, v.33, n.2, p.118-25, Feb. 1998.

40 - FELIX, R.; CECCHINI, M.G.; FLEISCH, H. Macrophage colony stimulating factor restores in vivo bone resorption in the OP/OP osteoporotic mouse. Endocrinol, V.127, n.5, p.2592-4, Nov. 1990.

41 - FREEZER, S.R.; SIMS, M.R. A transmission electron-microscope stereological study of the blood vessels, oxytalan fibres and nerves of mouse-molar periodontal ligament. Arch Oral Biol, v.32, n.6, p.407-12, 1987.

42 - FRISTAD, I.; HEYERAAS, K.J.; KVINNSLAND, I. Nerve fibres and cells immunoreactive to neurochemical markers in developing rat molars and supporting tissues. Arch Oral Biol, v.39, n.8, p.633-46, Aug. 1994.

43 - FRISTAD. I. et al. Effect of inferior alveolar nerve axotomy on immune cells and nerve fibres in young rat molars. Arch Oral Biol, v.40, n.11, p.1053-62, Nov. 1995.

44 - FUKUI, T. Analysis of stress-strain curves in the rat molar periodontal ligament after application of prthodontic force. Am J Orthod Dentofac Orthop, v.104, n.1, p. 27-35, July 1993. 
45 - FULlMER, H.M. Histochemical stidues of the periodontium. J Dent Res, v.45, n.3, p.469-77, 1966.

46 - FULLMER, H.M.; SHEETZ, J.H.; NARKATES, A.J. Oxytalan connective tissue fibers: a review. J Oral Pathol, v.3, n.6, p.291-316, 1974.

47 - GAENGLER, P.; MERTE, K. Effects on force application on periodontal blood circulation: a vital microscopic study in rats. J Periodont Res, v.18, n.1, p.8692, Jan. 1983.

48 - GAO, Z.; FLAITZ, C.M.; MACKENZIE, I.C. Expression of keratinocyte growth factor in periapical lesions. J Dent Res, v.75, n.9, p.1658-63, Sept. 1996.

49 - GARFUNKEL, A.; SCIAKY, I. Vascularization of the periodontal tissues in the adult laboratory rat. J Dent Res, v.50, n.4, p.880-7, July/Aug. 1971.

50 - GIANELLY, A.A. Force-induced changes in the vascularity of the periodontal ligament. Am J Orthod, v.55, n.1, p. 5-11, Jan. 1969.

51 - GOLDIE, R.S.; KING, G.J. Root resorption and tooth movement in orthodontically treated, calcium-deficient, and lactating rats. Am J Orthod, v.85, n.5, p. 42430, May 1984.

52 - GRIGORIADIS, A.E. et al. c-fos: a key regulator of osteoclast-macrophage lineage determination and bone remodeling. Science, v.266, n.5184, p.443-8, Oct. 1994.

53 - GRIMM, F.M. Bone bending, a feature of orthodontic tooth movement. Am J Orthod, v.62, n.4, p. 384-93, Oct. 1972.

54 - HALE, S.L.; VIVALDI, M.T.; KLONER, R.A. Fluorescent microspheres: a new tool for visualization of ischemic myocardium in rats. Am J Phys, v.251, n.4, pt. 2, p.H863-8, Oct. 1986.

55 - HAMAYA, M. et al. Cell death of osteocytes occurs in rat alveolar bone during experimental tooth movement. Calcif Tissue Int, v.70, n.2, p.117-26, Feb. 2002.

56 - HASHIMOTO, F. et al. Administration of osteocalcin accelerates orthodontic tooth movement induced by a closed coil spring in rats. Eur J Orthod, v.23, n.5, p.535-45, Oct. 2001.

57 - HAYASHI, S. et al. The development of terminal Schwann cells associated with periodontal Ruffini endings in the rat incisor ligament. Brain Res, v.858, n.1, p.167-71, Mar. 2000.

58 - HELLER, I.J.; NANDA, R. Affect of metabolic alteration of periodontal fibers on orthodontic tooth movement. An experimental study. Am J Orthod, v.75, n.3, p.239-58, Mar. 1979.

59 - HIKIJI, H. et al. Direct action of nitric oxide on osteoblastic differentiation. FEBS Lett, v.410, n.2-3, p.238-42, June 1997.

60 - HIROSHIMA, K. et al. Calretinin-like immunoreactivity in the regenerating periodontal Ruffini endings of the rat incisor following injury to the inferior alveolar nerve. Brain Res, v.807, n.1/2, p.218-21, Oct. 1998. 
61 - HIRUMA, Y. et al. Edothelins inhibit the mineralization of osteoblastic MC3T3-E1 cells through the A-type endothelin receptor. Am J Phys, v.275, n.4, p. R1099105, Oct. 1998.

62 - HUGHES, B.; KING, G.J. Effect of orthodontic appliance reactivation during the period of peak expansion in the osteoclast population. Anat Rec, v.251, n.1, p.80-8, May 1998.

63 - ICHIKAWA, H.; SUGIMOTO, T. NADPH-diaphorase activity in nerves and Scwann cells in the periodontal ligament of rat incisor teeth. Arch Oral Biol, v.43, n.2, p.167-71, Feb. 1998.

64 - ICHIKAWA, H.; JACOBOWITZ, D.M.; SUGIMOTO, T. Coexpression of calretin and parvalbumin in Ruffini-like endings in the rat incisor periodontal ligament. Brain Res, v.770, n.1/2, p.294-7, Oct. 1997.

65 - IMAMURA, N.; NAKATA, S.; NAKASIMA, A. Changes in periodontal pulsation in relation to increasing loads on rat molars and to blood pressure. Arch Oral Biol, v.47, n.8, p.599-606, Aug. 2002.

66 - INOUÉ, S. et al. The microfibrils of connective tissue: II. Immunohistochemical detection of the amyloid P component. Am J Anat, v.176, n.2, p.139-52 June 1986.

67 - ISHII, N.; SOMA, K.; TODA, K. Response properties of periodontal mechanoreceptors in rats, in vitro. Brain Res Bull, v.58, n.4, p.357-61, Aug. 2002 .

68 - JEE, W.S.S.; LI, X.J. Adaptation of cancellous bone to overloading in the adult rat: a single photon absorptiometry and histomorphometric study. Anat Rec, v.227, n.4, p.418-26, Aug. 1990.

69 - JOHANSEN, J.R. Incorporation of tritiated thymidine by the epithelial rests os Malassez after attempted extraction of rat molars. Acta Odont Scand, v.28, n.4, p.463-70, Aug. 1970.

70 - JOHN, S.A. et al. Connexin-43 hemichannels opened by metabolic inhibition. J Biol Chem, v.274, n.1, p.236-40, Jan. 1999.

71 - JOHNSON, R.B.; HIGHISON, G.J. Ultrasonic microdissection of the mouse mandible: exposure of the vasculature of alveolar bone and myelinated axons of the pulp. Anat Rec, v.211, n.1, p. 96-101, Jan. 1985.

72 - JONAS, I.E.; RIEDE, U.N. Reaction of oxytalan fibers in human periodontium to mechanical stress: a combined histochemical and morphometric analysis. J Histochem Cytochem, v.28, n.3, p.211-6, Mar. 1980.

73 - JUNQUEIRA, P.A.A. et al. Osteoporose. Rev Ginec Obst. v.13, n.3, p.142-56, 2001 .

74 - KAHN, A.J.; SIMMONS, D.J. Investigation of cell lineage in bone using a chimaera of chick and quail embryonic tissue. Nature, v.258, n.5533, p.325-27, Nov. 1975. 
75 - KAKU, M. et al. Effects os vascular endothelial growth factor on osteoclasts induction during tooth movement in mice. J Dent Res, v.80, n.10, p.1880-3, Oct. 2001.

76 - KHOUW, F.E.; GOLDHABER, P. Changes in vasculature of the periodontium associated with tooth movement in the rhesus monkey and dog. Arch Oral Biol, v.15, n.12, p.1125-32, Dec. 1970.

77 - KI, H.R. The effects of orthodontic forces on the mechanical properties of the periodontal ligament in the rat maxillary molars. Am J Orthod Dentofac Orthop, v.98, n.6, p.533-43, Dec. 1990.

78 - KIMURA, R. et al. Dental root resorption and repair: histology and histometry during physiological drift of rat molars. J Periodont Res, v.38, n.5, p.525-32, Oct. 2003.

79 - KINDLOVÁ, M. The blood supply of the marginal periodontium in macacus rhesus. Arch Oral Biol, v.10, n.6, p.869-74, Nov./Dec. 1965.

80 - KINDLOVÁ, M.; MATĚNA, V. Blood vessels of the rat molar. J Dent Res, v.41, n.3, p.650-60, May/June 1962.

81 - KING, G.J. et al. Measuring dental drift and orthodontic tooth movement in response to various initial forces in adult rats. Am J Orthod Dentofac Orthop, v.99, n.5, p.456-65, May 1991.

82 - KOBAYASHI, $\mathrm{H}$. et al. Alterations in ultrastructural localization of growthassociated protein-43 (GAP-43) in periodontal Ruffini endings of rat molars during experimental tooth movement. J Dent Res, v.77, n.3, p.503-17, Mar. 1998.

83 - KOBAYASHI, $H$. et al. Effects of local administration of osteocalcin on experimental tooth movement. Angle Orthod, v.68, n.3, p.259-66, June 1998.

$84-$ KOHNO, S. et al. Expression of vascular endothelial growth factor and the effects on bone remodeling during experimental tooth movement. J Dent Res, v.82, n.3, p.177-82, Mar. 2003.

85 - KOHNO, T. et al. Experimental tooth movement under light orthodontic forces: rates of tooth movement and changes of the periodontium. J Orthod, v.29, n.2, p.129-35, June 2002.

86 - KUFTINEC, M.M. Vascular changes due to the application of force to the molar teeth in hamsters. J Dent Res, v.47, n.6, p.916-8, Nov./Dec. 1968.

87 - KURIHARA, S.; ENLOW, D.H. An electron microscopic study of attachments between periodontal fibers and bone during alveolar remodeling. Am J Orthod, v.77, n.5, p.516-31, May 1980.

88 - KVINNSLAND, I.; KVINNSLAND, S. Changes in CGRP-immunoreactive nerve fibres during experimental tooth movement in rats. Eur J Orthod, v.12, n.3, p.320-9, Aug. 1990.

89 - KVINNSLAND, S.; HEYERAAS, K.; ØFJORD, S. Effect of experimental tooth movement on periodontal and pulpal blood flow. Eur J Orthod, v.11, n.3, p.200-5, Aug. 1989. 
90 - KYOMEN, S.; TANNE, K. Influences of aging changes in proliferative rate of PDL cells during experimental tooth movement in rats. Angle Orthod, v.67, n.1, p.67-72, 1997.

91 - LARA, V.S. et al. Dentin-induced in vivo inflammatory response and in vitro activation of murine macrophages. J Dent Res, v.82, n.6, p.460-5, 2003.

92 - LASFARGUES, J.J.; SAFFAR, J.L. Inhibition of prostanoid synthesis depresses alveolar bone resorption but enhances root resorption in the rat. Anat Rec, v.237, n.4, p.458-65, Nov. 1993.

93 - LEIKER, B.J. et al. The effects of exogenous prostaglandins on orthodontic tooth movement in rats. Am J Orthod Dentofac Orthop, v.108, n.4, p.380-8, Oct. 1995.

94 - LEKIC, P. et al. Bisphosphonate modulates proliferation and differentiation of rat periodontal ligament cells during wound healing. Anat Rec, v.247, n.3, p.32940, Mar. 1997.

95 - LEONORA, J.; TJÄDERHANE, L.; TIECHE, J.M. Parotid gland function and dentin apposition in rat molars. J Dent Res, v.81, n.4, p.259-64, Apr. 2002.

96 - LEW, K.K.K. The periodontal microvasculature - a morphological and morphometric study. J Nihon Univ Sch Dent, v.29, n.4, p.262-9, Dec. 1987.

97 - LEW, K.K.K. Orthodontically induced microvascular injuries in the tension zone of the periodontal ligament. J Nihon Univ Sch Dent, v.31, n.3, p.493-501, Sept. 1989.

98 - LEW, K.K.K.; SIMS, M.R.; LEPPARD, P.I. Tooth extrusion effects on microvesse volumes, endotelial areas, and fenestrae in molar apical periodontal ligament. Am J Orthod Dentofac Orthop, v.96, n.3, p.221-31, Sept. 1989.

99 - LÓPEZ OTERO, R. et al. Histologic and histometric study of bone resortion after tooth movement in rats. J Period Res, v.8, n.5, p. 327-33, 1973.

100 - MABUCHI, R.; MATSUZAKA, K.; SHIMONO, M. Cell proliferation and cell death in periodontal ligaments during orthodontic tooth movement. J Periodont Res, v.37, n.2, p.118-24, Apr. 2002.

101 - MACAPANPAN, L.C.; WEINMANN, M.D.; BRODIE, A.G. Early tissue changes following tooth movemnt in rats. Angle Orthod, v.24, n.1, p.79-95, Jan. 1954.

102 - MAEDA, T.; BYERS, M.R. Dit localizations of growth-associated protein (GAP43 ) in mechanoreceptors and free nerve endings of adult rat ligament periodontal, dental pulp and skin. Arch Histol Cytol, v.59, n.3, p.291-304, Aug. 1996.

103 - MAEDA, T. et al. The ultrastructural of Ruffini endings the periodontal ligament of rat incisors with special reference to the terminal Schwann cells (K-cells). Anat Rec, v.223, n.1, p.95-103, Jan. 1989.

104 - MALONE, J.D. et al. Recruitment of osteoclast precursors by purified matrix constituents. J Cell Biol, v.92, n.1, p.227-30, Jan. 1982. 
105 - MANCINI, L. et al. The biphasic effects of nitric oxide primary rat osteoblasts are cGMP dependent. Biochem Biophys Res Comm, v.274, n.2, p.477-81, Aug. 2000 .

106 - MARKS JUNIOR, S.C. The origin of osteoclasts: evindence, clinical implications and investigative challenges of an extra-skeletal source. J Oral Pathol, v.12, n.4, p.226-54, Aug. 1983.

107 - MARKS JUNIOR, S.C.; GROLMAN, M. Tartrate-resistant acid phosphatase in mononuclear and multinuclear cells during the bone resorption of tooth eruption. J Histoch Cytol, v.35, n.11, p.1227-30, Nov. 1987.

108 - MARLETA, M.A. Nitric oxide synthase structure and mechanism. J Biol Chem, v.268, n.7, p.12231-4, June 1993.

109 - McCULLOCH, C.A.G.; MELCHER, A.H. Cell density and cell generation in the periodontal ligament of mice. Am J Anat, v.167, n.1, p.43-58, May 1983.

110 - McCULLOCH, C.A.G.; MELCHER, A.H. Cell migration in the periodontal ligament of mice. J Periodont Res, v.18, n.4, p.339-52, July 1983.

111 - McCUlLOCH, C.A.G.; MELCHER, A.H. Continuous labelling of the periodontal ligament of mice. J Periodont Res, v.18, n.3, p.231-41, May. 1983.

112 - MELSEN, B. Tissue reaction to orthodontic tooth movement - a new paradigm. Eur J Orthod, v.23, n.6, p.671-81, Dec. 2001.

113 - MIDGETT, R.J.; SHAYE, R.; FRUGE, J.F. The effect of altered bone metabolism on orthodontic tooth movement. Am J Orthod, v.80, n.3, p.256-62, Sept. 1981.

114 - MOYERS, R.E.; BAUER, J.L. The periodontal response to various tooth movements. Am J Orthod, v.36, n.8, p.572-80, Aug. 1950.

115 - MUNDY, G.R. et al. Resorbing bone is chemotactic for monocytes. Nature, v.275, n.5676, p.132-5, Sept. 1978.

116 - MURAMOTO, T.; TAKANO, Y.; SOMA, K. Time-related changes in periodontal mechanoreceptors in rat molars after the loss of occlusal stimuli. Arch Histol Cytol, v.63, n.4, p.369-80, Oct. 2000.

117 - NAGAI, M. et al. Messenger RNA level and protein localization of transforming growth factor- $\beta_{1}$ in experimental tooth movements in rats. Eur J Oral Sci, v.107, n.6, p.475-81, Dec. 1999.

118 - NAKAKURA-OHSHIMA, K. et al. Immunocytochemical detection of S-100 $\beta$ in the periodontal Ruffini endings in the rat incisor. Neurosc Lett, v.258, n.3, p.163-6, Dec. 1998.

119 - NAKANE, S.; KAMEYAMA, Y. Root resorption caused by mechanical injury of the periodontal soft tissues in rats. J Periodont Res, v.22, n.5, p.390-5, Sept. 1987.

120 - OGAWA, T. et al. Changes in response properties of periodontal mechanoreceptors during tooth movement in rats. J Med Dent Sci, v.49, n.3, p.95-101, Sept. 2002. 
121 - OHKAWA, S. Effects of orthodontic forces and anti-inflammatory drugs on the mechanical strength of the periodontium in the rat mandibular first molar. Am J Orthod, v.81, n.6, p. 498-502 June 1982.

122 - OHSHIMA, O. et al. Prolonged effects of hypofunction on the mechanical strength of the periodontal ligament in rat mandibular molars. Arch Oral Biol, v.36, n.12, p.905-11, 1991.

123 - OKUDA, K. et al. TGF- $\beta 1$ influences early gingival wound healing in rats: an immunohistochemical evaluation of stromal remodelling by exrtacellular matrix molecules and PCNA. J Oral Pathol Med, v.27, n.10, p. 463-9, Nov. 1998.

124 - OWAN, I. et al. Mechanotransduction in bone: osteoblasts are more responsive to fluid forces than mechanical strain. Am J Phys, v.273, n.3, p. C810-5, Sept. 1997.

125 - PAVLIN, D. Mechanical loading stimulates differentiation of periodontal osteoblasts in a mouse osteoinduction model: effect on type I collagen and alkaline phosphatase genes. Calcif Tissue Int, v.67, n.2, p.163-72, Aug. 2000.

126 - PENDER, N.; HEANEY, T. G. Migration and proliferation of progenitor cells in the connective tissue of rat gingival papilla. J Periodont Res, v.30, n.5, p.3128, Sept. 1995.

127 - PEREIRA, A.A. C. Influência da ovariectomia a movimentação dentária induzida: avaliação microscópica. Bauru 2000. 127p. Tese (Doutorado) Faculdade de Odontologia de Bauru, Universidade de São Paulo.

128 - PERINETTI, G. et al. Alkaline phosphatase activity in gingival crevicular fluid during human orthodontic tooth movement. Am J Orthod Dentofac Orthop, v.122, n.5, p.548-56, Nov. 2002.

129 - RAGNARSSON, B.; CARR, G.; DANIEL, J.C. Isolation and growth of human periodontal ligament cells in vitro. J Dent Res, v.64, n.8, p.1026-30, Aug. 1985.

130 - REITAN, K. Behavior of Malassez epithelial rests during orthodontic tooth movement. Acta Odontol Scand, v.19, n.3-4, p.443-63, Dec. 1961.

131 - REITAN, K. Effects of force mognitude and direction of tooth movement on different alveolar bone types. Angle Orthod, v.34, n.4, p.244-55, Oct. 1964.

132 - REITAN, K. Initial tissue behavior during apical root resorption. Angle Orthod, v.44, n.1, p.68-82, Jan. 1974.

133 - REITAN, K.; KVAM, E. Comparative behavior of human and experimental animal tissue during experimental tooth movement. Angle Orthod, v.41, n.1, p.1-14, Jan. 1971.

134 - ROBERTS, W.E.; CHASE, W.S.S. Cell kinetics of orthodontically-stimulated and non-stimulated periodontal ligament in the rat. Arch Oral Biol, v.19, n.1, p.17-21, Jan. 1974.

135 - ROBERTS, W.E.; CHASE, D.C. Kinetics of cell proliferation and migration associated with orthodontically-induced osteogenesis. J Dent Res, v.60, n.2, p.174-81, Feb. 1981. 
136 - RODRIGUEZ, L.A. et al. An original orthodontic aplliance for experimental mesial movements in rats. Acta Odontol Latinoam, v.9, n.2, p.45-9, 1996.

137 - RYGH, P. Ultrasctructural vascular changes in pressure zone of rat molar periodontium incident to orthodontic movement. Scand J Dent, v.80, n.4, p.307-21, 1972.

138 - RYGH, P. Ultrasctructural changes of the periodontal fibers d their attachment in rat molar periodontium incident to orthodontic tooth movement. Scand J Dent, v.81, n.6, p.467-80, 1973.

139 - RYGH, P. Elimination of hyalinized periodontal tissues associated with orthodontic tooth movement. Scand J Dent, v.82, n.1, p.57-73, 1974.

140 - RYGH, P. Ultrastructural changes in tension zones of rat molar periodontium incident to orthodontic tooth movement. Am J Orthod, v.70, n.3, p.269-81, Sept. 1976.

141 - RYGH, P. Orthodontic root resorption studied by electron microscopy. Angle Orthod, v.47, n.1, p.1-16, Jan. 1977.

142 - RYGH, P. et al. Activation of vascular system: A main mediator of periodontal fiber remodeling in orthodontic tooth movement. Am J Orthod, v.89, n.6, p. 453-68, June 1986.

143 - SALO, J. et al. Removal of osteoclast bone resorption products by transcytosis. Science, v.276, n.5310, n.270-3, Apr. 1997.

144 - SANDSTEDT, C. Einige beitrage zur theorie der Zahn regulierung. Nord. Tandl. Tidsskr. n.4, 1904 apud HELLER, I. J.; NANDA, R. Affect of metabolic alteration of periodontal fibers on orthodontic tooth movement. An experimental study. Am J Orthod, v.75, n.3, p.239-58, Mar. 1979.

145 - SANDY, J.R.; FARNDALE, R.W.; MEIKLE, M.C. Recent advances in understanding mechanically induced bone remodeling and their relevance to orthodontic theory and practice. Am J Orthod Dentofac Orthop, v.103, n.3, p.212-22, Mar. 1993.

146 - SATO, K.; HATTORI, M.; AOBA, T. Risturbed enamel mineralization in a rat incisor model. Adv Dent Res, v.10, n.2, p.216-24, Nov. 1996.

147 - SAYGIN, N.; GIANNOBILE, W.V.; SOMERMAN, M.J. Molecular and cell biology of cementum. Periodontol 2000, v.24, n.1, p.73-98, Oct. 2000.

148 - SCHELLENS, J.P.M.; EVERTS, V.; BEERTSEN, W. Resorption of connective tissue in the gingiva of the mouse incisor. Anat Rec, v.195, n.1, p.95-107, Sept. 1979.

149 - SCHELLENS, J.P.M.; EVERTS, V.; BEERTSEN, W. Quantitative analysis of connective tissue resorption in the supra-alveolar region of the mouse incisor ligament. J Period Res, v.17, n.4, p.407-22, July 1982.

150 - SCHROEDER, H.E. Blood and nerve supply. In: OKSCHE, A.; VOLLRATH, L. Handbook of microscopic anatomy - The periodotium. Springer-Verlag, Berlin-Heidelberg-New York, 1986. P. 208-21 apud ASAHITO, T. et al. Postnatal expression of calretinin-immunoreactivity in periodontal Ruffini 
endings in the rat incisor: a comparasion with protein gene product 9.5 (PGP 9.5) - immunoreactivity. Arch Histol Cytol, v.6, n.1, p.57-69, Mar. 1999.

151 - SELLISETH, N.J.; SELVIG, K.A. The vasculature of the periodontal ligament: a scanning electron microscopic study using corrosion casts in the rat. $\mathbf{J}$ Periodontol, v.65, n.11, p.1079-87, Nov. 1994.

152 - SELVIG, K.A. Electron microscopy of Hertwig's epithelial sheath and of early dentin and cementum formation in the mouse incisor. Acta Odonto Scand, v.21, p.175-87, Apr. 1963.

153 - SELVIG, K.A. An ultrastructural study of cementum formation. Acta Odonto Scand, v.22, p.105-10, Feb. 1964.

154 - SHIRAZI, M. et al. The role of nitric oxide orthondontic tooth movement in rats. Angle Orthod, v.72, n.3, p.211-15, June 2002.

155 - SHORE, R.C.; BERKOVITZ, B.K.B. Model to explain differential movement of periodontal fibroblasts. Arch Oral Biol, v.23, n. 6, p.507-09, 1978.

156 - SILVA, T.A. Ativação osteoblástica e mecanismos de migração de neutrófilos induzidos pela dentina. Bauru 2003. 80p. Tese (Doutorado) - Faculdade de Odontologia de Bauru, Universidade de São Paulo.

157 - SIMS, M.R. Oxytalan fibers system of molars in the mouse mandible. J Dent Res, v.52, n.3, p.797-802, July-Aug. 1973.

158 - SIMS, M.R. Oxytalan-vascular relationships observed in histologic examination of the periodotal ligaments of man and mouse. Arch Oral Biol, v.20, n.11, p.713-6, Nov. 1975.

159 - SIMS, M.R. Reconstitution of the human oxytalan system during orthodontic tooth movement. Am J Orthod, v.70, n.1, p.38-58, July 1976.

160 - SIMS, M.R. Endothelium-1 expression in the vasculature of normal and 3-hour continuously loaded rat molar periodontal ligament. Eur J Orthod, v.23, n.6, p.647-62, Dec. 2001.

161 - SMITH, R.K.; ROBERTS, W.E. Cell kinetics of the initial response to orthodontically induced osteogenesis in rat molar periodontal ligament. Calcif Tissue Int, v.30, n.1, p.51-6, 1980.

162 - SU, M. et al. Expression of connexin 43 in rat mandibular bone and periodontal ligament (PDL) cells during experimental tooth movement. J Dent Res, v.76, n.7, p.1357-66, July 1997.

163 - TABATA, T.; TAKAHASHI, Y.; HAYASHI, H. Response properties of periodontal mechanosensitive neurones in the rat trigeminal sensory complex projecting to the posteromedial ventral nucleus of the thalamus. Arch Oral Biol, v.46, n.10, p.881-9, Oct. 2001.

164 - TABATA, T. et al. Physiological properties of periodontal mechanosensitive neurones in the posteromedial ventral nucleus of rat thalamus. Arch Oral Biol, v.47, n.9, p.689-94, Sept. 2002. 
165 - TAKANO, Y. et al. Differential involvement of matrix vesicles during the initial and appositional mineralization processes in bone, dentin, and cementum. Bone, v.26, n.4, p.333-9, Apr. 2000.

166 - TALIC, N.F. et al. Proliferation of epithelial rests of Malassez during experimental tooth movement. Am J Orthod Dentofac Orthop, v.123, n.5, p.527-33, May 2003.

167 - TANG, M.P.F.; SIMS, M.R. A TEM analysis of tissue channels in normal and orthodontically tensioned rat molar periodonatl ligament. Eur J Orthod, v.14, n.6, p.433-44, Dec. 1992.

168 - TANG, M.P.F. et al. Evidence for endothelial junctions acting as a fluid flux pathway in tensioned periodontal ligament. Arch Oral Biol, v.38, n.3, p.273-6, Mar. 1993.

169 - TASHIRO, K. et al. Development of oxytalan fibers in the rat molar perodontal ligament. J Periodont Res, v.37, n.5, p.345-52, Oct. 2002.

170 - TEN CATE, A.R.; DEPORTER, D.A.; FREEMAN, E. The role of fibroblasts in the remodeling of periodontal ligament during physiologic tooth movement. Am J Orthod, v.69, n.2, p.155-68, Feb. 1976.

171 - TENSHIN, S. et al. Remodeling mechanisms of transseptal fibers during and after tooth movement. Angle Orthod, v.65, n.2, p.141-50, 1995.

172 - TOMS, A.; GANNON, B.; CARATI, C. The immunohistochemical response of the rat periodontal ligament endothelium to an inflammatory stimulus. Austr Orthod J, v.16, n.2, p.61-8, July 2000.

173 - TØNDER, K.J.H. Vascular reactions in the dental pulp during inflammation. Acta Odontol Scand, v.41, n.4, p.247-56, Aug. 1983.

174 - TRAN VAN, P.; VIGNERY, A.; BARON, R. Cellular kinetics of the bone remodelling sequence in the rat. Anat Rec, v.202, n.4, p.445-51, Apr. 1982.

175 - TSAY, T.P.; CHEN, M.; OYEN, O.J. Osteoclasts activation and recruitment after application of orthodontic force. Am J Orthod Dentofac Orthop, v.115, n.3, p.323-30, Mar. 1999.

176 - TSUKADA, H. et al. Developmental changes of the vasculature in the periodontal ligament of rat molars: a scanning electron microscopic study of microcorrosion casts. J Periodont Res, v.35, n.4, p.201-7, Aug. 2000.

177 - TSURUTA, M. et al. Effect of experimental tooth movement on the mechanical strength of the periodontium in the rat mandibular first molar. Arch Oral Biol, v.27, n.10, p.875-9, 1982.

178 - TURNER, H. et al. Visualization of the microcirculation of the periodontium. $\mathbf{J}$ Periodontol, v.40, n.2, p.222-30, Apr. 1969.

179 - UBIOS, A.M.; COSTA, O.R.; CABRINI, R.L. Early steps in bone resorption in experimental periodontitis: a histomorphometric study. Acta Odontol Latinoam, v.7, n.1, p.45-50, 1993.

180 - UEMATSU, S.; MOGI, M.; DEGUCHI, T. Interleukin (IL)-1 $\beta$, IL-6, tumor necrosis factor- $\alpha$, epidermal growth factor, and $\beta 2$-microglobulin levels are 
elevated in gingival crevicular fluid during human orthodontic tooth movement. J Dent Res, v.75, n.1, p.562-7, Jan. 1996.

181 - VANDEVSKA-RADUNOVIC, V.; KVINNSLAND, I.H.; KVINNSLAND, S. Effect of alveolar nerve axotomy on periodontal and pulpal blood flow subsequent to experimental tooth movement in rats. Acta Odontol Scand, v.56, n.1, p.57-64, Feb. 1998.

182 - VANDEVSKA-RADUNOVIC, V.; KVINNSLAND, S.; KVINNSLAND, I.H. Effect of experimental tooth movement on nerves fibres immunoreactive to calcitonin gene-related peptide, protein gene product 9.5, and blood vessel density and distribuition in rats. Eur J Orthod, v.19, n.5, p.517-29, Oct. 1997.

183 - VANDEVSKA-RADUNOVIC, V. et al. Changes in blood circulation in teeth and supporting tissues incident to experimental tooth movement. Eur J Orthod, v.16, n.5, p.361-9, Oct. 1994.

184 - VASCONCELOS, M.H.F. Análise morfológica comparativa do periodonto de sustentação submetido a forças biologicamente excessivas, em ratas adultas sem e sob o uso de anticoncepcionais e ratas prenhes. Bauru, 1996. 148p. Tese (Doutorado) - Faculdade de Odontologia de Bauru, Universidade de São Paulo.

185 - VERNA, C.; MELSEN, B. Tissue reaction to orthodontic tooth movement in different bone turnover conditions. Orthod Craniofacial Res, v.6, n.3, p.15563, Aug. 2003.

186 - VERNA, C.; ZAFFE, D.; SICILIANI, G. Histomorphometric study of bone reactions during orthodontic tooth movement in rats. Bone, v.24, n.4, p.371-9, Apr. 1999.

187 - VIGNERY, A.; BARON, R. Dynamic histomorphometry of alveolar bone remodeling in the adult rat. Anat Rec, v.196, n.2, p.191-200, Feb. 1980.

188 - WAKISAKA, S. et al. Morphological and cytochemical characteristics of periodontal Ruffini ending under normal and regeneration processes. Arch Histol Cytol, v.63, n.2, p.91-113, May 2000.

189 - WALDO, C.M.; ROTHBLATT, J.M. Histologic response to tooth movement in the laboratory rat. J Dent Res, v.33, n.4, p.481-6, Aug. 1954.

190 - WALLACH, S. et al. Physical and biochemical factors in bone metabolism. Calcif Tissue Int, v.50, n.1, p.1-4, Jan. 1992.

191 - WANG, Z. et al. Bone and haematopoietic defects in mice lacking c-fos. Nature, v.360, n.24, p.741-5, Dec. 1992.

192 - WEEKES, W.T.; SIMS, M.R. The vasculature of the rat molar periodontal ligament. J Period Res, v.21, n.3, p.186-94, May 1986.

193 - WESSELINK, P.R.; BEERTSEN, W. The prevalence and distribuition of rests of Malassez in the mouse molar and their possible role in repair and maintenance of the periodontal ligament. Arch Oral Biol, v.38, n.5, p.399-403, May 1993. 
194 - WESSELINK, P.R.; BEERTSEN, W.; EVERTS, V. Resorption of the mouse incisor after the application of cold to the periodontal attachment apparatus. Calcif Tissue Int, v.39, n.1, p.11-21, July 1986.

195 - WILLIAMS, S.A histomorphometric study of orthodontically induced root resorption. Eur J Orthod, v.6, n.1, p.35-47, Feb. 1984.

196 - YAMAGUCHI, K.; NANDA, R.S. Blood flow changes in gingival tissues due to the displacement of teeth. Angle Orthod, v.62, n.4, p.257-64, Winter 1992.

197 - YAMAMOTO, H. et al. Immunocytochemical detection of superoxide dismutases (SODs) in the periodontal Ruffini endings of the rat incisor. Brain Res, v.905, n.1/2, p.232-5, June 2001.

198 - YAMASAKI, K.; MIURA, F.; SUDA, T. Prostaglandin as a mediator of bone resortion induced by experimental tooth movement in rats. J Dent Res, v.59, n.10, p.1635-42, Oct. 1980.

199 - YAMASAKI, K. The role of cyclic AMP, caicium, and prostaglandins in the induction of osteoclastic bone resortion associated with experimental tooth movement. J Dent Res, v.62, n.8, p.877-81, Aug. 1983.

200 - YOKOYA, K.; SASAKI, T.; SHIBASAKI, Y. Distributional changes of osteoclasts and pre-osteoclastic cells in periodontal tissues during experimental tooth movment as revealed by quantitative immunohistochemical of $\mathrm{H}+-$ ATPase. J Dent Res, v.76, n.1, p.580-7, Jan. 1997.

201 - YOUN, S.H. et al. Growth-associated protein-43 (GAP-43) in the regenerating periodontal Ruffini endings of the rat incisor following injury to the inferior alveolar nerve. Brain Res, v.787, n.1, p.41-8, Mar. 1998.

202 - ZAKI, A.E.; VAN HUYSEN, G. Histology of the periodontium following tooth movement. J Dent Res, v.42, n.6, p.1373-9, Nov./Dec. 1963.

203 - ZENGO, A.N.; PAWLUK, R.J.; BASSETT, C.A.L. Stress-induced bioeletric potentials in the dentoalveolar complex. Am J Orthod, v.64, n.1, p.17-27, July 1973.

204 - ZEREDO, J.L.; TODA, K.; SOMA, K. Neck motor unit activities induced by inputs from periodontal mechanoreceptors in rats. J Dent Res, v.81, n.1, p.3942, Jan. 2002.

205 - ZHOU, D.; HUGHES, B.; KING, G.J. Histomorphometric and bichemical study of osteoclasts at orthodontic compression sites in the rat during indomethacin inhibition. Arch Oral Biol, v.42, n.10-11, p.717-26, Oct./Nov. 1997. 
ABSTRACT

$\longrightarrow$ 


\section{ABSTRACT \\ MICROSCOPIC ANALYSIS OF THE TISSUE PHENOMENONS OF THE INDUCED TOOTH MOVEMENT IN RATS IN PERIOD RANGING FROM 1-7 DAYS}

The induced tooth movement is a multiple biology process characterized by sequenced reactions of the periodontal tissue as an answer to the biomechanic forces. The induced tissue changes are related to its remodeling through the activation of the alveolar bone reabsorption in the side where the pression occurs and a consequently bone apposition in the tension side. The created stimulae due to mechanical stress during the induced tooth movement measured the tissue changes. This, together with the chemical mediators result in a new periodontal homeostatic condition, such as hyalinization, remodelling and reabsorption. Aiming to establish an ideal time to observe the alterations since the beginning of the experimental induced tooth movement, a daily morphological tissue profile was designed since the beginning steps in rats using as a control the teeth in the opposite side which were not moved. It was considered: the aspects of normality (in the control side) and the microscopics phenomena observed during the induced tooth movement since the beginnig steps detailing them; the extension and intensity of the bone and tooth resorption. The sample was made up in twenty-one male Wistar rats which underwent a induced tooth movement for a period raging between 1 to 7 days using the closed coil spring (HELLER; NANDA model). Based in the observation and considering the morphology, it was concluded that: the celular and tissue morphologic changes in the periodontal tension side from the teeth under mechanical stress did not suffer from a great variation anging the groups for the experimental model; the morphologic changes in the pressure and tension sides were gradually intensified as the length of the experimental time passed by, nevertheless without occourring a tooth resorption; the ideal time of induced tooth movement in this kind of rats is within a period where there is a balance between the applied force and the not destroyed and irreversibly morphologic changes gotten. Here, the fifth day after force was applied. 
ANEXOS 
Anexo 1 - Distribuição dos achados microscópicos referentes aos fenômenos morfologicamente detectados nos animais do Grupo C-1

\begin{tabular}{|c|c|c|c|c|c|c|c|c|c|c|c|c|c|c|}
\hline \multirow{3}{*}{\multicolumn{3}{|c|}{ Espécimes }} & \multicolumn{6}{|c|}{ ÁREA DE PRESSÃO } & \multicolumn{6}{|c|}{ ÁREA DE TENSÃO } \\
\hline & & & \multicolumn{3}{|c|}{ raiz mesial } & \multicolumn{3}{|c|}{ Raiz distal } & \multicolumn{3}{|c|}{ Raiz distal } & \multicolumn{3}{|c|}{ Raiz mesial } \\
\hline & & & 1 & 2 & 3 & 1 & 2 & 3 & 1 & 2 & 3 & 1 & 2 & 3 \\
\hline \multicolumn{3}{|c|}{ Fenômenos } & 1 & 2 & 3 & 1 & 2 & 3 & 1 & 2 & 3 & 1 & 2 & 3 \\
\hline \multirow{21}{*}{ 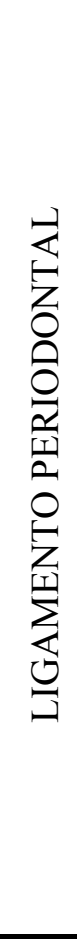 } & \multirow{2}{*}{ Largura } & aumentada & & & & & & & & & & & & \\
\hline & & diminuída & & & & & & & & & & & & \\
\hline & \multirow{2}{*}{$\begin{array}{c}\text { Fibras } \\
\text { colágenas }\end{array}$} & perpendiculares & & $\mathrm{x}$ & $\mathrm{x}$ & & & & & & & & $\mathrm{x}$ & $\mathrm{x}$ \\
\hline & & ao acaso & & & & & & & & & & & & \\
\hline & \multirow{3}{*}{$\begin{array}{c}\text { Áreas } \\
\text { hialinas }\end{array}$} & pequenas & & & & & & & & & & & & \\
\hline & & Médias & & & & & & & & & & & & \\
\hline & & Grandes & & & & & & & & & & & & \\
\hline & \multirow{4}{*}{$\begin{array}{c}\text { Vasos } \\
\text { sangüíneos }\end{array}$} & normais & & $\mathrm{x}$ & $\mathrm{x}$ & & & & & & & & $\mathrm{x}$ & $\mathrm{x}$ \\
\hline & & comprimidos & & $\mathrm{x}$ & $\mathrm{x}$ & & & & & & & & $\mathrm{x}$ & $\mathrm{x}$ \\
\hline & & colabados & & & & & & & & & & & & \\
\hline & & dilatados & & & & & & & & & & & & \\
\hline & \multirow{4}{*}{$\begin{array}{l}\text { Alterações } \\
\text { circulatórias }\end{array}$} & congestão & & $\mathrm{x}$ & $\mathrm{x}$ & & & & & & & & $\mathrm{x}$ & $\mathrm{x}$ \\
\hline & & exsudato & & & & & & & & & & & & \\
\hline & & trombose & & & & & & & & & & & & \\
\hline & & hemorragia & & $\mathrm{x}$ & $\mathrm{x}$ & & & & & & & & $\mathrm{x}$ & $\mathrm{x}$ \\
\hline & \multirow{5}{*}{$\begin{array}{l}\text { Infiltrado } \\
\text { inflamatório }\end{array}$} & neutrófilos & & & & & & & & & & & & \\
\hline & & macrófagos & & $\mathrm{x}$ & $\mathrm{x}$ & & & & & & & & $\mathrm{x}$ & $\mathrm{x}$ \\
\hline & & plasmócitos & & & & & & & & & & & & \\
\hline & & linfócitos & & & & & & & & & & & & \\
\hline & & CGMN & & $\mathrm{x}$ & $\mathrm{x}$ & & & & & & & & $\mathrm{x}$ & $\mathrm{x}$ \\
\hline & \multicolumn{2}{|c|}{ Restos epiteliais de Malassez } & & & & & & & & & & & & \\
\hline \multirow{10}{*}{ 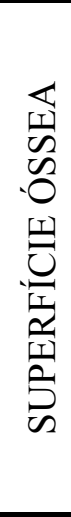 } & \multirow{4}{*}{$\begin{array}{c}\text { Face } \\
\text { periodontal }\end{array}$} & irregular c/ reabs & & & & & & & & & & & & \\
\hline & & irregular s/ reabs & & $\mathrm{x}$ & $\mathrm{x}$ & & & & & & & & & \\
\hline & & linha de reversão & & $\mathrm{x}$ & $\mathrm{x}$ & & & & & & & & & \\
\hline & & osteóide & & & & & & & & & & & & \\
\hline & \multirow{4}{*}{$\begin{array}{c}\text { Face } \\
\text { endosteal }\end{array}$} & irregular c/ reabs & & & & & & & & & & & $\mathrm{x}$ & $\mathrm{x}$ \\
\hline & & irregular s/ reabs & & & & & & & & & & & $\mathrm{x}$ & $\mathrm{x}$ \\
\hline & & linha de reversão & & & & & & & & & & & $\mathrm{x}$ & $\mathrm{x}$ \\
\hline & & osteóide & & & & & & & & & & & & \\
\hline & \multirow{2}{*}{ Crista óssea } & regular & & $\mathrm{x}$ & $\mathrm{x}$ & & & & & & & & & \\
\hline & & irregular & & & & & & & & & & & & \\
\hline \multirow{5}{*}{ 党 } & \multirow{4}{*}{$\begin{array}{l}\text { Superfície } \\
\text { cementária }\end{array}$} & regular & & $x$ & $\mathrm{x}$ & & & & & & & & $\mathrm{x}$ & \\
\hline & & irregular s/ reabs & & & & & & & & & & & & \\
\hline & & irregular c/ reabs & & & & & & & & & & & & \\
\hline & & Cementóide & & & $\mathrm{x}$ & & & & & & & & & \\
\hline & Reabsorção & entinária externa & & & & & & & & & & & & \\
\hline
\end{tabular}




\begin{tabular}{|c|c|c|c|c|c|c|c|c|c|c|c|c|c|c|}
\hline \multicolumn{3}{|c|}{ Fenômenos } & $\begin{array}{l}1 \\
1 \\
\end{array}$ & $\begin{array}{l}2 \\
2 \\
\end{array}$ & $\begin{array}{l}3 \\
3 \\
\end{array}$ & $\begin{array}{l}1 \\
1 \\
\end{array}$ & $\begin{array}{l}2 \\
2 \\
\end{array}$ & $\begin{array}{l}3 \\
3 \\
\end{array}$ & $\begin{array}{l}1 \\
1 \\
\end{array}$ & $\begin{array}{l}2 \\
2 \\
\end{array}$ & $\begin{array}{l}3 \\
3 \\
\end{array}$ & $\begin{array}{l}1 \\
1 \\
\end{array}$ & $\begin{array}{l}2 \\
2 \\
\end{array}$ & $\begin{array}{l}3 \\
3 \\
\end{array}$ \\
\hline \multirow{5}{*}{$\begin{array}{l}n \\
0 \\
0 \\
0 \\
0 \\
0 \\
0 \\
0 \\
01\end{array}$} & \multirow{3}{*}{ Núcleo } & mitótico & & & & & & & & & & & & \\
\hline & & picnótico & & & & & & & & & & & & \\
\hline & & cariorrexe & & & & & & & & & & & & \\
\hline & \multirow{2}{*}{$\begin{array}{c}\text { Quanto à } \\
\text { disposição }\end{array}$} & fasciculado & & $\mathrm{x}$ & $\mathrm{x}$ & & & & & & & & $x$ & $\mathrm{x}$ \\
\hline & & ao acaso & & & & & & & & & & & & \\
\hline \multirow{7}{*}{$\begin{array}{l}n \\
0 \\
\tilde{n} \\
\frac{\tilde{0}}{0} \\
0 \\
0 \\
0 \\
0\end{array}$} & \multirow{3}{*}{ Núcleo } & mitótico & & & & & & & & & & & & \\
\hline & & picnótico & & & & & & & & & & & & \\
\hline & & cariorrexe & & & & & & & & & & & & \\
\hline & \multirow{2}{*}{$\begin{array}{c}\text { Quanto à } \\
\text { disposição }\end{array}$} & fasciculado & & & & & & & & & & & & \\
\hline & & ao acaso & & & & & & & & & & & & \\
\hline & \multirow{2}{*}{$\begin{array}{l}\text { Quanto à } \\
\text { superfície }\end{array}$} & justapostos & & $\mathrm{x}$ & $\mathrm{x}$ & & & & & & & & $\mathrm{x}$ & $\mathrm{x}$ \\
\hline & & à distância & & & & & & & & & & & & \\
\hline \multirow{6}{*}{$\begin{array}{l}0 \\
0 \\
0 \\
\frac{\pi}{0} \\
0 \\
0 \\
\frac{0}{\tilde{D}} \\
0\end{array}$} & \multirow{3}{*}{ Núcleo(s) } & mitótico & & & & & & & & & & & & \\
\hline & & picnótico & & & & & & & & & & & & \\
\hline & & cariorrexe & & & & & & & & & & & & \\
\hline & \multirow{3}{*}{$\begin{array}{l}\text { Quanto à } \\
\text { superfície }\end{array}$} & à distância & & & & & & & & & & & $\mathrm{x}$ & \\
\hline & & justapostos & & & & & & & & & & & $\mathrm{x}$ & \\
\hline & & em lacunas & & & & & & & & & & & & $\mathrm{x}$ \\
\hline \multirow{7}{*}{$\begin{array}{l}0 \\
0 \\
0 \\
\frac{0}{0} \\
0 \\
0 \\
0 \\
0 \\
0 \\
0 \\
0 \\
0\end{array}$} & \multirow{3}{*}{ Núcleo } & mitótico & & & & & & & & & & & & \\
\hline & & picnótico & & & & & & & & & & & & \\
\hline & & cariorrexe & & & & & & & & & & & & \\
\hline & \multirow{2}{*}{$\begin{array}{c}\text { Quanto à } \\
\text { disposição }\end{array}$} & em paliçada & & $\mathrm{x}$ & $\mathrm{x}$ & & & & & & & & $\mathrm{x}$ & $\mathrm{x}$ \\
\hline & & ao acaso & & & & & & & & & & & & \\
\hline & \multirow{2}{*}{$\begin{array}{l}\text { Quanto à } \\
\text { superfície }\end{array}$} & justapostos & & $\mathrm{x}$ & $\mathrm{x}$ & & & & & & & & $\mathrm{x}$ & $\mathrm{x}$ \\
\hline & & à distância & & & & & & & & & & & & \\
\hline \multirow{6}{*}{$\begin{array}{l}\frac{n}{0} \\
\frac{\mathbb{E}}{0} \\
\stackrel{0}{0} \\
\stackrel{0}{0} \\
\stackrel{0}{0}\end{array}$} & \multirow{3}{*}{ Núcleo(s) } & mitótico & & & & & & & & & & & & \\
\hline & & picnótico & & & & & & & & & & & & \\
\hline & & cariorrexe & & & & & & & & & & & & \\
\hline & \multirow{3}{*}{$\begin{array}{l}\text { Quanto à } \\
\text { superfície }\end{array}$} & à distância & & & & & & & & & & & & \\
\hline & & justapostos & & $\mathrm{x}$ & & & & & & & & & & \\
\hline & & em lacunas & & & & & & & & & & & & \\
\hline
\end{tabular}

T - total; X - presença; c/ - com; s/ - sem; reabs - reabsorção; CGMN - células gigantes multinucleadas. 
Anexo 2 - Distribuição dos achados microscópicos referentes aos fenômenos morfologicamente detectados nos animais do Grupo C-2

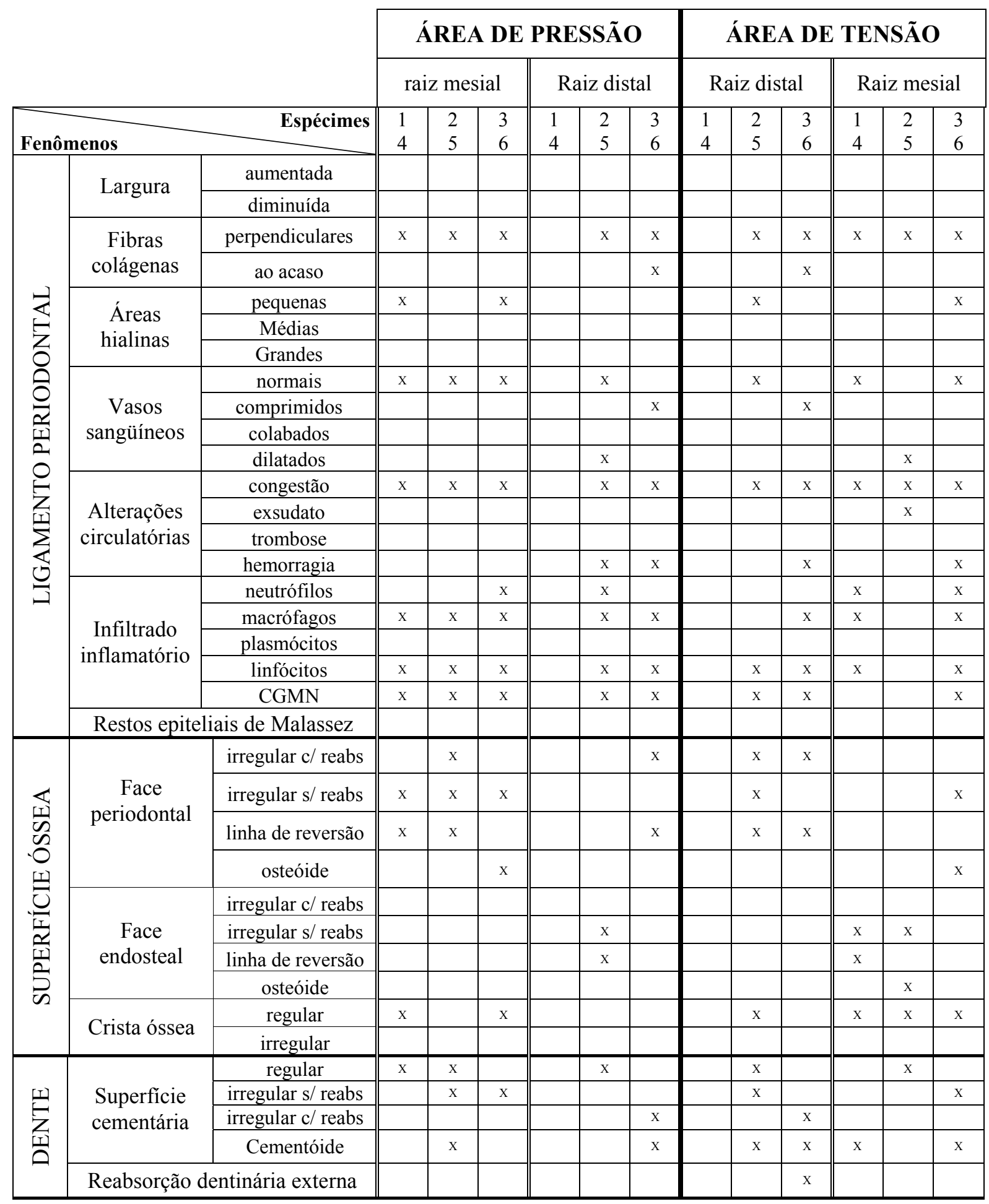




\begin{tabular}{|c|c|c|c|c|c|c|c|c|c|c|c|c|c|c|}
\hline \multicolumn{3}{|c|}{$\begin{array}{ll}\text { Fenômenos } & \text { Espécimes } \\
\end{array}$} & $\begin{array}{l}1 \\
4 \\
\end{array}$ & $\begin{array}{l}2 \\
5 \\
\end{array}$ & $\begin{array}{l}3 \\
6 \\
\end{array}$ & $\begin{array}{l}1 \\
4 \\
\end{array}$ & $\begin{array}{l}2 \\
5 \\
\end{array}$ & $\begin{array}{l}3 \\
6 \\
\end{array}$ & $\begin{array}{l}1 \\
4 \\
\end{array}$ & $\begin{array}{l}2 \\
5 \\
\end{array}$ & $\begin{array}{l}3 \\
6 \\
\end{array}$ & $\begin{array}{l}1 \\
4 \\
\end{array}$ & $\begin{array}{l}2 \\
5 \\
\end{array}$ & $\begin{array}{l}3 \\
6 \\
\end{array}$ \\
\hline \multirow{5}{*}{ 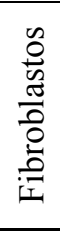 } & \multirow{3}{*}{ Núcleo } & mitótico & & & & & & & & & & & & \\
\hline & & picnótico & & & & & & $\mathrm{x}$ & & & $\mathrm{x}$ & $\mathrm{x}$ & & \\
\hline & & cariorrexe & & & & & & & & & & & & \\
\hline & \multirow{2}{*}{$\begin{array}{l}\text { Quanto à } \\
\text { disposição }\end{array}$} & fasciculado & $\mathrm{x}$ & $\mathrm{x}$ & $\mathrm{x}$ & & $\mathrm{x}$ & $\mathrm{x}$ & & & $\mathrm{x}$ & & $\mathrm{x}$ & $\mathrm{x}$ \\
\hline & & ao acaso & & & & & & $x$ & & & $\mathrm{x}$ & & & \\
\hline \multirow{7}{*}{$\begin{array}{l}0 \\
0 \\
\frac{n}{0} \\
\frac{\pi}{0} \\
0 \\
\frac{D}{n} \\
0\end{array}$} & \multirow{3}{*}{ Núcleo } & mitótico & & & & & & & & & & & & \\
\hline & & picnótico & & & & & & & & & & & & \\
\hline & & cariorrexe & & & & & & & & & & & & \\
\hline & \multirow{2}{*}{$\begin{array}{l}\text { Quanto à } \\
\text { disposição }\end{array}$} & fasciculado & $\mathrm{x}$ & $\mathrm{x}$ & $\mathrm{x}$ & & $\mathrm{x}$ & $\mathrm{x}$ & & & $\mathrm{x}$ & $\mathrm{x}$ & $\mathrm{x}$ & $\mathrm{x}$ \\
\hline & & ao acaso & & & & & & $x$ & & & $\mathrm{x}$ & & & \\
\hline & \multirow{2}{*}{$\begin{array}{l}\text { Quanto à } \\
\text { superfície }\end{array}$} & justapostos & $\mathrm{x}$ & $\mathrm{x}$ & $\mathrm{x}$ & & $\mathrm{x}$ & $\mathrm{x}$ & & & $\mathrm{x}$ & $\mathrm{x}$ & $\mathrm{x}$ & $\mathrm{x}$ \\
\hline & & à distância & & & & & & & & & & & & \\
\hline \multirow{6}{*}{$\begin{array}{l}0 \\
0 \\
\frac{n}{0} \\
\frac{\pi}{0} \\
0 \\
\frac{d}{0} \\
0\end{array}$} & \multirow{3}{*}{ Núcleo(s) } & mitótico & & & & & & & & & & & & \\
\hline & & picnótico & & & & & & & & & & & & \\
\hline & & cariorrexe & & & & & & & & & & & & \\
\hline & \multirow{3}{*}{$\begin{array}{l}\text { Quanto à } \\
\text { superfície }\end{array}$} & à distância & & & & & & & & & & & & \\
\hline & & justapostos & $\mathrm{x}$ & $\mathrm{x}$ & $\mathrm{x}$ & & $\mathrm{x}$ & $\mathrm{x}$ & & $\mathrm{x}$ & $\mathrm{x}$ & & & $\mathrm{x}$ \\
\hline & & em lacunas & & $\mathrm{x}$ & & & & $\mathrm{x}$ & & $\mathrm{x}$ & $\mathrm{x}$ & & & \\
\hline \multirow{7}{*}{ 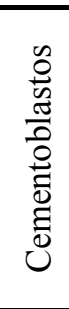 } & \multirow{3}{*}{ Núcleo } & mitótico & & & & & & & & & & & & \\
\hline & & picnótico & & & & & & & & & & & & \\
\hline & & cariorrexe & & & & & & & & & & & & \\
\hline & \multirow{2}{*}{$\begin{array}{l}\text { Quanto à } \\
\text { disposição }\end{array}$} & em paliçada & $\mathrm{x}$ & $\mathrm{x}$ & $\mathrm{x}$ & & $\mathrm{x}$ & & & $\mathrm{x}$ & & $\mathrm{x}$ & $\mathrm{x}$ & $\mathrm{x}$ \\
\hline & & ao acaso & & & & & & & & & & & & \\
\hline & \multirow{2}{*}{$\begin{array}{l}\text { Quanto à } \\
\text { superfície }\end{array}$} & justapostos & $\mathrm{x}$ & $\mathrm{x}$ & $\mathrm{x}$ & & $\mathrm{x}$ & & & $\mathrm{x}$ & & $\mathrm{x}$ & $\mathrm{x}$ & $\mathrm{x}$ \\
\hline & & à distância & & & & & & & & & & & & \\
\hline \multirow{6}{*}{ 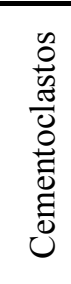 } & \multirow{3}{*}{ Núcleo(s) } & mitótico & & & & & & & & & & & & \\
\hline & & picnótico & & & & & & & & & & & & \\
\hline & & cariorrexe & & & & & & & & & & & & \\
\hline & \multirow{3}{*}{$\begin{array}{l}\text { Quanto à } \\
\text { superfície }\end{array}$} & à distância & & & & & & & & & & & & \\
\hline & & justapostos & & & & & & $\mathrm{x}$ & & & $\mathrm{x}$ & & $\mathrm{x}$ & \\
\hline & & em lacunas & & & & & & $\mathrm{x}$ & & & $\mathrm{x}$ & & & \\
\hline
\end{tabular}

$\mathrm{T}$ - total; $\mathrm{X}$ - presença; c/ - com; s/ - sem; reabs - reabsorção; CGMN - células gigantes multinucleadas. 
Anexo 3 - Distribuição dos achados microscópicos referentes aos fenômenos morfologicamente detectados nos animais do Grupo C-3

\begin{tabular}{|c|c|c|c|c|c|c|c|c|c|c|c|c|c|c|}
\hline \multirow{3}{*}{\multicolumn{3}{|c|}{ 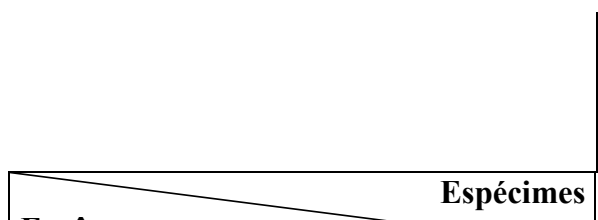 }} & \multicolumn{6}{|c|}{ ÁREA DE PRESSÃO } & \multicolumn{6}{|c|}{ ÁREA DE TENSÃO } \\
\hline & & & \multicolumn{3}{|c|}{ raiz mesial } & \multicolumn{3}{|c|}{ Raiz distal } & \multicolumn{3}{|c|}{ Raiz distal } & \multicolumn{3}{|c|}{ Raiz mesial } \\
\hline & & & 1 & 2 & 3 & 1 & 2 & 3 & 1 & 2 & 3 & 1 & 2 & 3 \\
\hline \multicolumn{3}{|c|}{ Fenômenos } & 7 & 8 & 9 & 7 & 8 & 9 & 7 & 8 & 9 & 7 & 8 & 9 \\
\hline \multirow{21}{*}{ 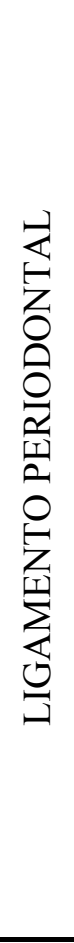 } & \multirow{2}{*}{ Largura } & aumentada & & & & & & & & & & & & \\
\hline & & diminuída & & & & & & & & & & & & \\
\hline & \multirow{2}{*}{$\begin{array}{c}\text { Fibras } \\
\text { colágenas }\end{array}$} & perpendiculares & & $\mathrm{x}$ & & & $\mathrm{x}$ & & & $\mathrm{x}$ & & & $\mathrm{x}$ & \\
\hline & & ao acaso & & & & & & & & & & & $\mathrm{x}$ & \\
\hline & \multirow{3}{*}{$\begin{array}{c}\text { Áreas } \\
\text { hialinas }\end{array}$} & pequenas & & $\mathrm{x}$ & & & $\mathrm{x}$ & & & $\mathrm{x}$ & & & $\mathrm{x}$ & \\
\hline & & Médias & & & & & & & & & & & & \\
\hline & & Grandes & & & & & & & & & & & & \\
\hline & \multirow{4}{*}{$\begin{array}{c}\text { Vasos } \\
\text { sangüíneos }\end{array}$} & normais & & $\mathrm{x}$ & & & $\mathrm{x}$ & & & & & & $\mathrm{x}$ & \\
\hline & & comprimidos & & & & & & & & & & & & \\
\hline & & colabados & & & & & & & & & & & & \\
\hline & & dilatados & & & & & & & & & & & & \\
\hline & \multirow{4}{*}{$\begin{array}{l}\text { Alterações } \\
\text { circulatórias }\end{array}$} & congestão & & $\mathrm{x}$ & & & $\mathrm{x}$ & & & & & & $\mathrm{x}$ & \\
\hline & & exsudato & & & & & $\mathrm{x}$ & & & & & & $\mathrm{x}$ & \\
\hline & & trombose & & & & & & & & & & & & \\
\hline & & hemorragia & & & & & & & & & & & & \\
\hline & \multirow{5}{*}{$\begin{array}{l}\text { Infiltrado } \\
\text { inflamatório }\end{array}$} & neutrófilos & & $\mathrm{x}$ & & & $\mathrm{x}$ & & & & & & $\mathrm{x}$ & \\
\hline & & macrófagos & & $\mathrm{x}$ & & & $\mathrm{x}$ & & & & & & $\mathrm{x}$ & \\
\hline & & plasmócitos & & & & & & & & & & & & \\
\hline & & linfócitos & & $\mathrm{x}$ & & & $\mathrm{x}$ & & & & & & $\mathrm{x}$ & \\
\hline & & CGMN & & & & & & & & $\mathrm{x}$ & & & $\mathrm{x}$ & \\
\hline & \multicolumn{2}{|c|}{ Restos epiteliais de Malassez } & & & & & & & & & & & & \\
\hline \multirow{10}{*}{ 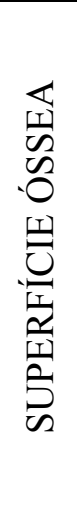 } & \multirow{4}{*}{$\begin{array}{l}\text { Face } \\
\text { periodontal }\end{array}$} & irregular c/ reabs & & & & & & & & $\mathrm{x}$ & & & & \\
\hline & & irregular s/ reabs & & $\mathrm{x}$ & & & & & & $\mathrm{x}$ & & & & \\
\hline & & linha de reversão & & $\mathrm{x}$ & & & & & & $\mathrm{x}$ & & & & \\
\hline & & osteóide & & & & & & & & & & & & \\
\hline & \multirow{4}{*}{$\begin{array}{c}\text { Face } \\
\text { endosteal }\end{array}$} & irregular c/ reabs & & & & & & & & & & & & \\
\hline & & irregular s/ reabs & & & & & $\mathrm{x}$ & & & & & & $\mathrm{x}$ & \\
\hline & & linha de reversão & & & & & $\mathrm{x}$ & & & & & & $\mathrm{x}$ & \\
\hline & & osteóide & & & & & $\mathrm{x}$ & & & & & & $\mathrm{x}$ & \\
\hline & \multirow{2}{*}{ Crista óssea } & regular & & & & & & & & & & & & \\
\hline & & irregular & & & & & $\mathrm{x}$ & & & & & & $\mathrm{x}$ & \\
\hline \multirow{5}{*}{$\frac{1}{\underbrace{\prime}_{1}}$} & \multirow{4}{*}{$\begin{array}{l}\text { Superfície } \\
\text { cementária }\end{array}$} & regular & & $\mathrm{x}$ & & & & & & $\mathrm{x}$ & & & & \\
\hline & & irregular s/ reabs & & $\mathrm{x}$ & & & & & & & & & & \\
\hline & & irregular c/ reabs & & & & & & & & & & & & \\
\hline & & Cementóide & & $\mathrm{x}$ & & & & & & $\mathrm{x}$ & & & & \\
\hline & Reabsorção c & entinária externa & & & & & & & & & & & $\mathrm{x}$ & \\
\hline
\end{tabular}




\begin{tabular}{|c|c|c|c|c|c|c|c|c|c|c|c|c|c|c|}
\hline \multicolumn{3}{|c|}{ Fenômenos $\quad$ Espécimes } & $\begin{array}{l}1 \\
7\end{array}$ & $\begin{array}{l}2 \\
8\end{array}$ & $\begin{array}{l}3 \\
9\end{array}$ & $\begin{array}{l}1 \\
7\end{array}$ & $\begin{array}{l}2 \\
8\end{array}$ & $\begin{array}{l}3 \\
9\end{array}$ & $\begin{array}{l}1 \\
7\end{array}$ & $\begin{array}{l}2 \\
8\end{array}$ & $\begin{array}{l}3 \\
9\end{array}$ & 1 & $\begin{array}{l}2 \\
8\end{array}$ & $\begin{array}{l}3 \\
9\end{array}$ \\
\hline \multirow{5}{*}{$\begin{array}{l}0 \\
0 \\
\tilde{0} \\
\frac{\pi}{0} \\
0 \\
0 \\
0 \\
0\end{array}$} & \multirow{3}{*}{ Núcleo } & mitótico & & & & & & & & & & & & \\
\hline & & picnótico & & & & & & & & & & & & \\
\hline & & cariorrexe & & & & & & & & & & & & \\
\hline & \multirow{2}{*}{$\begin{array}{c}\text { Quanto à } \\
\text { disposição }\end{array}$} & fasciculado & & $\mathrm{x}$ & & & $\mathrm{x}$ & & & $\mathrm{x}$ & & & $\mathrm{x}$ & \\
\hline & & ao acaso & & & & & $\mathrm{x}$ & & & & & & $\mathrm{x}$ & \\
\hline \multirow{7}{*}{$\begin{array}{l}\frac{n}{0} \\
\frac{n}{0} \\
\frac{\pi}{0} \\
0 \\
0 \\
\frac{d}{\infty} \\
0\end{array}$} & \multirow{3}{*}{ Núcleo } & mitótico & & & & & & & & & & & & \\
\hline & & picnótico & & & & & & & & & & & & \\
\hline & & cariorrexe & & & & & & & & & & & & \\
\hline & \multirow{2}{*}{$\begin{array}{c}\text { Quanto à } \\
\text { disposição }\end{array}$} & fasciculado & & $\mathrm{x}$ & & & $\mathrm{x}$ & & & $\mathrm{x}$ & & & $\mathrm{x}$ & \\
\hline & & ao acaso & & & & & $\mathrm{x}$ & & & & & & $\mathrm{x}$ & \\
\hline & \multirow{2}{*}{$\begin{array}{l}\text { Quanto à } \\
\text { superfície }\end{array}$} & justapostos & & $\mathrm{x}$ & & & $\mathrm{x}$ & & & $\mathrm{x}$ & & & $\mathrm{x}$ & \\
\hline & & à distância & & & & & & & & & & & & \\
\hline \multirow{6}{*}{ 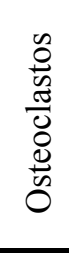 } & \multirow{3}{*}{ Núcleo(s) } & mitótico & & & & & & & & & & & & \\
\hline & & picnótico & & & & & & & & & & & & \\
\hline & & cariorrexe & & & & & & & & & & & & \\
\hline & \multirow{3}{*}{$\begin{array}{l}\text { Quanto à } \\
\text { superfície }\end{array}$} & à distância & & & & & & & & & & & & \\
\hline & & justapostos & & & & & & & & & & & & \\
\hline & & em lacunas & & & & & & & & $\mathrm{x}$ & & & & \\
\hline \multirow{7}{*}{ 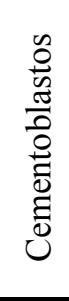 } & \multirow{3}{*}{ Núcleo } & mitótico & & & & & & & & & & & & \\
\hline & & picnótico & & & & & & & & & & & & \\
\hline & & cariorrexe & & & & & & & & & & & & \\
\hline & \multirow{2}{*}{$\begin{array}{c}\text { Quanto à } \\
\text { disposição }\end{array}$} & em paliçada & & $\mathrm{x}$ & & & $\mathrm{x}$ & & & $\mathrm{x}$ & & & $\mathrm{x}$ & \\
\hline & & ao acaso & & & & & & & & & & & & \\
\hline & \multirow{2}{*}{$\begin{array}{c}\text { Quanto à } \\
\text { superfície }\end{array}$} & justapostos & & $\mathrm{x}$ & & & $\mathrm{x}$ & & & $\mathrm{x}$ & & & $\mathrm{x}$ & \\
\hline & & à distância & & & & & & & & & & & & \\
\hline \multirow{6}{*}{ 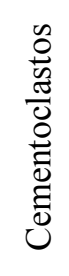 } & \multirow{3}{*}{ Núcleo(s) } & mitótico & & & & & & & & & & & & \\
\hline & & picnótico & & & & & & & & & & & & \\
\hline & & cariorrexe & & & & & & & & & & & & \\
\hline & \multirow{3}{*}{$\begin{array}{l}\text { Quanto à } \\
\text { superfície }\end{array}$} & à distância & & & & & & & & & & & & \\
\hline & & justapostos & & & & & & & & & & & $\mathrm{x}$ & \\
\hline & & em lacunas & & & & & & & & & & & $\mathrm{x}$ & \\
\hline
\end{tabular}

T - total; X - presença; c/ - com; s/ - sem; reabs - reabsorção; CGMN - células gigantes multinucleadas. 
Anexo 4 - Distribuição dos achados microscópicos referentes aos fenômenos morfologicamente detectados nos animais do Grupo C-4

\begin{tabular}{|c|c|c|c|c|c|c|c|c|c|c|c|c|c|c|}
\hline \multirow{3}{*}{\multicolumn{3}{|c|}{ Espécimes }} & \multicolumn{6}{|c|}{ ÁREA DE PRESSÃO } & \multicolumn{6}{|c|}{ ÁREA DE TENSÃO } \\
\hline & & & \multicolumn{3}{|c|}{ raiz mesial } & \multicolumn{3}{|c|}{ Raiz distal } & \multicolumn{3}{|c|}{ Raiz distal } & \multicolumn{3}{|c|}{ Raiz mesial } \\
\hline & & & $\begin{array}{c}1 \\
10 \\
\end{array}$ & $\begin{array}{c}2 \\
11 \\
\end{array}$ & \begin{tabular}{|c|}
3 \\
12 \\
\end{tabular} & $\begin{array}{c}1 \\
10 \\
\end{array}$ & $\begin{array}{c}2 \\
11 \\
\end{array}$ & $\begin{array}{c}3 \\
12 \\
\end{array}$ & $\begin{array}{c}1 \\
10 \\
\end{array}$ & $\begin{array}{c}2 \\
11 \\
\end{array}$ & $\begin{array}{c}3 \\
12 \\
\end{array}$ & $\begin{array}{c}1 \\
10 \\
\end{array}$ & $\begin{array}{c}2 \\
11 \\
\end{array}$ & $\begin{array}{c}3 \\
12 \\
\end{array}$ \\
\hline \multirow{21}{*}{ 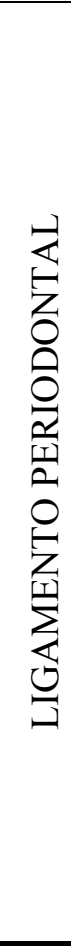 } & \multirow{2}{*}{ Largura } & aumentada & & & & & & & & & & & & \\
\hline & & diminuída & & & & & & & & & & & & $\mathrm{x}$ \\
\hline & \multirow{2}{*}{$\begin{array}{c}\text { Fibras } \\
\text { colágenas }\end{array}$} & perpendiculares & & $\mathrm{x}$ & $\mathrm{x}$ & & & & & & & & $\mathrm{x}$ & \\
\hline & & ao acaso & & & & & & & & & & $\mathrm{x}$ & $\mathrm{x}$ & \\
\hline & \multirow{3}{*}{$\begin{array}{c}\text { Áreas } \\
\text { hialinas }\end{array}$} & pequenas & & $\mathrm{x}$ & & & & & & & & & & \\
\hline & & Médias & & & & & & & & & & & & \\
\hline & & Grandes & & & & & & & & & & & & \\
\hline & \multirow{4}{*}{$\begin{array}{c}\text { Vasos } \\
\text { sangüíneos }\end{array}$} & normais & & $\mathrm{x}$ & & & & & & & & & $\mathrm{x}$ & $\mathrm{x}$ \\
\hline & & comprimidos & & & & & & & & & & & & \\
\hline & & colabados & & & & & & & & & & & & \\
\hline & & dilatados & & $\mathrm{x}$ & & & & & & & & & $\mathrm{x}$ & $\mathrm{x}$ \\
\hline & \multirow{4}{*}{$\begin{array}{l}\text { Alterações } \\
\text { circulatórias }\end{array}$} & congestão & & $\mathrm{x}$ & & & & & & & & & $\mathrm{x}$ & $\mathrm{x}$ \\
\hline & & exsudato & & & $\mathrm{x}$ & & & & & & & & $\mathrm{x}$ & \\
\hline & & trombose & & & & & & & & & & & & \\
\hline & & hemorragia & & & & & & & & & & & $\mathrm{x}$ & \\
\hline & \multirow{5}{*}{$\begin{array}{l}\text { Infiltrado } \\
\text { inflamatório }\end{array}$} & neutrófilos & & & $\mathrm{x}$ & & & & & & & & $\mathrm{x}$ & \\
\hline & & macrófagos & & $\mathrm{x}$ & $\mathrm{x}$ & & & & & & & & $\mathrm{x}$ & \\
\hline & & plasmócitos & & & & & & & & & & & & \\
\hline & & linfócitos & & & $\mathrm{x}$ & & & & & & & & $\mathrm{x}$ & \\
\hline & & CGMN & & $\mathrm{x}$ & $\mathrm{x}$ & & & & & & & & $\mathrm{x}$ & \\
\hline & \multicolumn{2}{|c|}{ Restos epiteliais de Malassez } & & & & & & & & & & & & \\
\hline \multirow{10}{*}{ 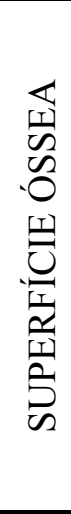 } & \multirow{4}{*}{$\begin{array}{c}\text { Face } \\
\text { periodontal }\end{array}$} & irregular c/ reabs & & $\mathrm{x}$ & & & & & & & & & & \\
\hline & & irregular s/ reabs & & $\mathrm{x}$ & $\mathrm{x}$ & & & & & & & & & \\
\hline & & linha de reversão & & $\mathrm{x}$ & & & & & & & & & & \\
\hline & & osteóide & & $\mathrm{x}$ & $\mathrm{x}$ & & & & & & & & & \\
\hline & \multirow{4}{*}{$\begin{array}{c}\text { Face } \\
\text { endosteal }\end{array}$} & irregular c/ reabs & & & & & & & & & & & $\mathrm{x}$ & $\mathrm{x}$ \\
\hline & & irregular s/ reabs & & & & & & & & & & & & \\
\hline & & linha de reversão & & & & & & & & & & & $\mathrm{x}$ & $\mathrm{x}$ \\
\hline & & osteóide & & & & & & & & & & & & $\mathrm{x}$ \\
\hline & \multirow{2}{*}{ Crista óssea } & regular & & $\mathrm{x}$ & $\mathrm{x}$ & & & & & & & & & \\
\hline & & irregular & & & & & & & & & & & $\mathrm{x}$ & \\
\hline \multirow{5}{*}{ 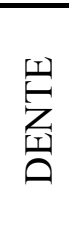 } & \multirow{4}{*}{$\begin{array}{l}\text { Superfície } \\
\text { cementária }\end{array}$} & regular & & $\mathrm{x}$ & & & & & & & & & & $\mathrm{x}$ \\
\hline & & irregular s/ reabs & & & & & & & & & & & $\mathrm{x}$ & \\
\hline & & irregular c/ reabs & & & $\mathrm{x}$ & & & & & & & & & \\
\hline & & Cementóide & & $\mathrm{x}$ & & & & & & & & & $\mathrm{x}$ & $\mathrm{x}$ \\
\hline & \multicolumn{2}{|c|}{ Reabsorção dentinária externa } & & & $\mathrm{x}$ & & & & & & & & & \\
\hline
\end{tabular}




\begin{tabular}{|c|c|c|c|c|c|c|c|c|c|c|c|c|c|c|}
\hline \multicolumn{3}{|c|}{$\begin{array}{ll}\text { Fenômenos } & \text { Espécimes } \\
\end{array}$} & $\begin{array}{c}1 \\
10 \\
\end{array}$ & $\begin{array}{c}2 \\
11 \\
\end{array}$ & $\begin{array}{c}3 \\
12 \\
\end{array}$ & $\begin{array}{c}1 \\
10 \\
\end{array}$ & $\begin{array}{c}2 \\
11 \\
\end{array}$ & $\begin{array}{c}3 \\
12 \\
\end{array}$ & $\begin{array}{c}1 \\
10 \\
\end{array}$ & $\begin{array}{c}2 \\
11 \\
\end{array}$ & $\begin{array}{c}3 \\
12 \\
\end{array}$ & $\begin{array}{c}1 \\
10 \\
\end{array}$ & $\begin{array}{c}2 \\
11 \\
\end{array}$ & $\begin{array}{c}3 \\
12 \\
\end{array}$ \\
\hline \multirow{5}{*}{ 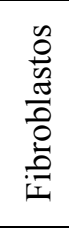 } & \multirow{3}{*}{ Núcleo } & mitótico & & & & & & & & & & & & \\
\hline & & picnótico & & & & & & & & & & & & \\
\hline & & cariorrexe & & & & & & & & & & & & \\
\hline & \multirow{2}{*}{$\begin{array}{c}\text { Quanto à } \\
\text { disposição }\end{array}$} & fasciculado & & $\mathrm{x}$ & $\mathrm{x}$ & & & & & & & & $\mathrm{x}$ & $\mathrm{x}$ \\
\hline & & ao acaso & & & & & & & & & & & $\mathrm{x}$ & $\mathrm{x}$ \\
\hline \multirow{7}{*}{$\begin{array}{l}\frac{n}{0} \\
\frac{\pi}{0} \\
\frac{\pi}{0} \\
0 \\
\frac{d}{0} \\
0\end{array}$} & \multirow{3}{*}{ Núcleo } & mitótico & & & & & & & & & & & & \\
\hline & & picnótico & & & & & & & & & & & & \\
\hline & & cariorrexe & & & & & & & & & & & & \\
\hline & \multirow{2}{*}{$\begin{array}{c}\text { Quanto à } \\
\text { disposição }\end{array}$} & fasciculado & & $\mathrm{x}$ & $\mathrm{x}$ & & & & & & & & & \\
\hline & & ao acaso & & & & & & & & & & & $\mathrm{x}$ & $\mathrm{x}$ \\
\hline & \multirow{2}{*}{$\begin{array}{l}\text { Quanto à } \\
\text { superfície }\end{array}$} & justapostos & & $\mathrm{x}$ & $\mathrm{x}$ & & & & & & & & $\mathrm{x}$ & $\mathrm{x}$ \\
\hline & & à distância & & & & & & & & & & & & \\
\hline \multirow{6}{*}{$\begin{array}{l}0 \\
0 \\
\frac{0}{0} \\
\frac{\pi}{0} \\
0 \\
\frac{D}{n} \\
0\end{array}$} & \multirow{3}{*}{ Núcleo(s) } & mitótico & & & & & & & & & & & & \\
\hline & & picnótico & & & & & & & & & & & & \\
\hline & & cariorrexe & & & & & & & & & & & & \\
\hline & \multirow{3}{*}{$\begin{array}{c}\text { Quanto à } \\
\text { superfície }\end{array}$} & à distância & & & & & & & & & & & & \\
\hline & & justapostos & & $\mathrm{x}$ & & & & & & & & & & \\
\hline & & em lacunas & & $x$ & & & & & & & & & $\mathrm{x}$ & \\
\hline \multirow{7}{*}{$\begin{array}{l}0 \\
0 \\
\frac{0}{0} \\
\frac{\pi}{0} \\
0 \\
\stackrel{0}{0} \\
\stackrel{0}{0}\end{array}$} & \multirow{3}{*}{ Núcleo } & mitótico & & & & & & & & & & & & \\
\hline & & picnótico & & & & & & & & & & & & \\
\hline & & cariorrexe & & & & & & & & & & & & \\
\hline & \multirow{2}{*}{$\begin{array}{c}\text { Quanto à } \\
\text { disposição }\end{array}$} & em paliçada & & $\mathrm{x}$ & & & & & & & & & & \\
\hline & & ao acaso & & & & & & & & & & & & \\
\hline & \multirow{2}{*}{$\begin{array}{c}\text { Quanto à } \\
\text { superfície }\end{array}$} & justapostos & & $\mathrm{x}$ & $\mathrm{x}$ & & & & & & & & & $\mathrm{x}$ \\
\hline & & à distância & & & & & & & & & & & & \\
\hline \multirow{6}{*}{ 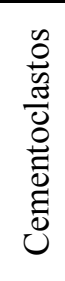 } & \multirow{3}{*}{ Núcleo(s) } & mitótico & & & & & & & & & & & & \\
\hline & & picnótico & & & & & & & & & & & & \\
\hline & & cariorrexe & & & & & & & & & & & & \\
\hline & \multirow{3}{*}{$\begin{array}{l}\text { Quanto à } \\
\text { superfície }\end{array}$} & à distância & & & $\mathrm{x}$ & & & & & & & & & \\
\hline & & justapostos & & & & & & & & & & & & \\
\hline & & em lacunas & & & & & & & & & & & & \\
\hline
\end{tabular}

T - total; X - presença; c/ - com; s/ - sem; reabs - reabsorção; CGMN - células gigantes multinucleadas. 
Anexo 5 - Distribuição dos achados microscópicos referentes aos fenômenos morfologicamente detectados nos animais do Grupo C-5

\begin{tabular}{|c|c|c|c|c|c|c|c|c|c|c|c|c|c|c|}
\hline \multirow{3}{*}{\multicolumn{3}{|c|}{ Fon }} & \multicolumn{6}{|c|}{ ÁREA DE PRESSÃO } & \multicolumn{6}{|c|}{ ÁREA DE TENSÃO } \\
\hline & & & \multicolumn{3}{|c|}{ raiz mesial } & \multicolumn{3}{|c|}{ Raiz distal } & \multicolumn{3}{|c|}{ Raiz distal } & \multicolumn{3}{|c|}{ Raiz mesial } \\
\hline & & & 1 & 2 & $\begin{array}{c}3 \\
15\end{array}$ & 1 & 2 & $\begin{array}{c}3 \\
15\end{array}$ & 1 & 2 & 3 & 1 & 2 & $\begin{array}{c}3 \\
15\end{array}$ \\
\hline \multicolumn{3}{|c|}{ Fenômenos } & 13 & 14 & 15 & 13 & 14 & 15 & 13 & 14 & 15 & 13 & 14 & 15 \\
\hline \multirow{21}{*}{ 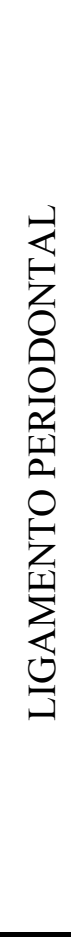 } & \multirow{2}{*}{ Largura } & aumentada & & & & & & & & & & & & \\
\hline & & diminuída & & & & & & & & & & & & \\
\hline & \multirow{2}{*}{$\begin{array}{c}\text { Fibras } \\
\text { colágenas }\end{array}$} & perpendiculares & $\mathrm{x}$ & $\mathrm{x}$ & $\mathrm{x}$ & & $\mathrm{x}$ & $\mathrm{x}$ & & $\mathrm{x}$ & $\mathrm{x}$ & $\mathrm{x}$ & $\mathrm{x}$ & $\mathrm{x}$ \\
\hline & & ao acaso & & & & & & $\mathrm{x}$ & & & $\mathrm{x}$ & & & \\
\hline & \multirow{3}{*}{$\begin{array}{c}\text { Áreas } \\
\text { hialinas }\end{array}$} & pequenas & $\mathrm{x}$ & & $\mathrm{x}$ & & & & & $\mathrm{x}$ & & & & $\mathrm{x}$ \\
\hline & & Médias & & & & & & & & & & & & \\
\hline & & Grandes & & & & & & & & & & & & \\
\hline & \multirow{4}{*}{$\begin{array}{c}\text { Vasos } \\
\text { sangüíneos }\end{array}$} & normais & $\mathrm{x}$ & $\mathrm{x}$ & $\mathrm{x}$ & & $\mathrm{x}$ & & & $\mathrm{x}$ & & $\mathrm{x}$ & & $\mathrm{x}$ \\
\hline & & comprimidos & & & & & & $x$ & & & $\mathrm{x}$ & & & \\
\hline & & colabados & & & & & & & & & & & & \\
\hline & & dilatados & & & & & $\mathrm{x}$ & & & & & & $\mathrm{x}$ & \\
\hline & \multirow{4}{*}{$\begin{array}{l}\text { Alterações } \\
\text { circulatórias }\end{array}$} & congestão & $\mathrm{x}$ & $\mathrm{x}$ & $\mathrm{x}$ & & $\mathrm{x}$ & $\mathrm{x}$ & & $\mathrm{x}$ & $\mathrm{x}$ & $\mathrm{x}$ & $\mathrm{x}$ & $\mathrm{x}$ \\
\hline & & exsudato & & & & & & & & & & & $\mathrm{x}$ & \\
\hline & & trombose & & & & & & & & & & & & \\
\hline & & hemorragia & & & & & $\mathrm{x}$ & $\mathrm{x}$ & & & $\mathrm{x}$ & & & $\mathrm{x}$ \\
\hline & \multirow{5}{*}{$\begin{array}{l}\text { Infiltrado } \\
\text { inflamatório }\end{array}$} & neutrófilos & & & $\mathrm{x}$ & & $\mathrm{x}$ & & & & & $\mathrm{x}$ & & $\mathrm{x}$ \\
\hline & & macrófagos & $\mathrm{x}$ & $\mathrm{x}$ & $\mathrm{x}$ & & $\mathrm{x}$ & $\mathrm{x}$ & & & $\mathrm{x}$ & $\mathrm{x}$ & & $\mathrm{x}$ \\
\hline & & plasmócitos & & & & & & & & & & & & \\
\hline & & linfócitos & $\mathrm{x}$ & $\mathrm{x}$ & $\mathrm{x}$ & & $\mathrm{x}$ & $\mathrm{x}$ & & $\mathrm{x}$ & $\mathrm{x}$ & $\mathrm{x}$ & & $\mathrm{x}$ \\
\hline & & CGMN & $\mathrm{x}$ & $\mathrm{x}$ & $\mathrm{x}$ & & $\mathrm{x}$ & $\mathrm{x}$ & & $\mathrm{x}$ & $\mathrm{x}$ & & & $\mathrm{x}$ \\
\hline & \multicolumn{2}{|c|}{ Restos epiteliais de Malassez } & & & & & & & & & & & & \\
\hline \multirow{10}{*}{ 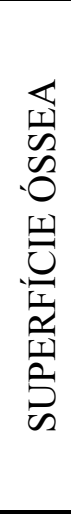 } & \multirow{4}{*}{$\begin{array}{c}\text { Face } \\
\text { periodontal }\end{array}$} & irregular c/ reabs & & $\mathrm{x}$ & & & & $\mathrm{x}$ & & $\mathrm{x}$ & $\mathrm{x}$ & & & \\
\hline & & irregular s/ reabs & $\mathrm{x}$ & $\mathrm{x}$ & $\mathrm{x}$ & & & & & $\mathrm{x}$ & & & & $\mathrm{x}$ \\
\hline & & linha de reversão & $\mathrm{x}$ & $\mathrm{x}$ & & & & $\mathrm{x}$ & & $\mathrm{x}$ & $\mathrm{x}$ & & & \\
\hline & & osteóide & & & $\mathrm{x}$ & & & & & & & & & $\mathrm{x}$ \\
\hline & \multirow{4}{*}{$\begin{array}{c}\text { Face } \\
\text { endosteal }\end{array}$} & irregular c/ reabs & & & & & & & & & & & & \\
\hline & & irregular s/ reabs & & & & & $\mathrm{x}$ & & & & & $\mathrm{x}$ & $\mathrm{x}$ & \\
\hline & & linha de reversão & & & & & $\mathrm{x}$ & & & & & $\mathrm{x}$ & & \\
\hline & & osteóide & & & & & & & & & & & $\mathrm{x}$ & \\
\hline & \multirow{2}{*}{ Crista óssea } & regular & $\mathrm{x}$ & & $\mathrm{x}$ & & & & & $\mathrm{x}$ & & $\mathrm{x}$ & $\mathrm{x}$ & $\mathrm{x}$ \\
\hline & & irregular & & & & & & & & & & & & \\
\hline \multirow{5}{*}{ 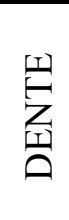 } & \multirow{4}{*}{$\begin{array}{l}\text { Superfície } \\
\text { cementária }\end{array}$} & regular & $\mathrm{x}$ & $\mathrm{x}$ & & & $\bar{x}$ & & & $\mathrm{x}$ & & & $\mathrm{x}$ & \\
\hline & & irregular s/ reabs & & $\mathrm{x}$ & $\mathrm{x}$ & & & & & $\mathrm{x}$ & & & & $\mathrm{x}$ \\
\hline & & irregular c/ reabs & & & & & & $\mathrm{x}$ & & & $\mathrm{x}$ & & & \\
\hline & & Cementóide & & $\mathrm{x}$ & & & & $\mathrm{x}$ & & $\mathrm{x}$ & $\mathrm{x}$ & $\mathrm{x}$ & & $\mathrm{x}$ \\
\hline & Reabsorção & ntinária externa & & & & & & & & & & $\mathrm{x}$ & & \\
\hline
\end{tabular}




\begin{tabular}{|c|c|c|c|c|c|c|c|c|c|c|c|c|c|c|}
\hline \multirow{2}{*}{\multicolumn{3}{|c|}{\begin{tabular}{|ll} 
Espécimes \\
\end{tabular}}} & 1 & 2 & 3 & 1 & 2 & 3 & 1 & 2 & 3 & 1 & 2 & 3 \\
\hline & & Fenômenos & 13 & 14 & 15 & 13 & 14 & 15 & 13 & 14 & 15 & 13 & 14 & 15 \\
\hline \multirow{5}{*}{ 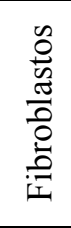 } & \multirow{3}{*}{ Núcleo } & mitótico & & & & & & & & & & & & \\
\hline & & picnótico & & & & & & $\mathrm{x}$ & & & $\mathrm{x}$ & $\mathrm{x}$ & & \\
\hline & & cariorrexe & & & & & & & & & & & & \\
\hline & \multirow{2}{*}{$\begin{array}{c}\text { Quanto à } \\
\text { disposição }\end{array}$} & fasciculado & $\mathrm{x}$ & $\mathrm{x}$ & $\mathrm{x}$ & & $\mathrm{x}$ & $\mathrm{x}$ & & & $\mathrm{x}$ & & $\mathrm{x}$ & $\mathrm{x}$ \\
\hline & & ao acaso & & & & & & $\mathrm{x}$ & & & $\mathrm{x}$ & & & \\
\hline \multirow{7}{*}{$\begin{array}{l}\frac{n}{0} \\
\frac{\pi}{0} \\
\frac{\pi}{0} \\
0 \\
\frac{d}{0} \\
0\end{array}$} & \multirow{3}{*}{ Núcleo } & mitótico & & & & & & & & & & & & \\
\hline & & picnótico & & & & & & & & & & & & \\
\hline & & cariorrexe & & & & & & & & & & & & \\
\hline & \multirow{2}{*}{$\begin{array}{c}\text { Quanto à } \\
\text { disposição }\end{array}$} & fasciculado & $\mathrm{x}$ & $\mathrm{x}$ & $\mathrm{x}$ & & $\mathrm{x}$ & $\mathrm{x}$ & & & $\mathrm{x}$ & $\mathrm{x}$ & $\mathrm{x}$ & $\mathrm{x}$ \\
\hline & & ao acaso & & & & & & $\mathrm{x}$ & & & $\mathrm{x}$ & & & \\
\hline & \multirow{2}{*}{$\begin{array}{l}\text { Quanto à } \\
\text { superfície }\end{array}$} & justapostos & $\mathrm{x}$ & $\mathrm{x}$ & $\mathrm{x}$ & & $\mathrm{x}$ & $\mathrm{x}$ & & & $\mathrm{x}$ & $\mathrm{x}$ & $\mathrm{x}$ & $\mathrm{x}$ \\
\hline & & à distância & & & & & & & & & & & & \\
\hline \multirow{6}{*}{ 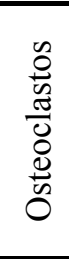 } & \multirow{3}{*}{ Núcleo(s) } & mitótico & & & & & & & & & & & & \\
\hline & & picnótico & & & & & & & & & & & & \\
\hline & & cariorrexe & & & & & & & & & & & & \\
\hline & \multirow{3}{*}{$\begin{array}{c}\text { Quanto à } \\
\text { superfície }\end{array}$} & à distância & & & & & & & & & & & & \\
\hline & & justapostos & $\mathrm{x}$ & $\mathrm{x}$ & $\mathrm{x}$ & & $\mathrm{x}$ & $\mathrm{x}$ & & $\mathrm{x}$ & $\mathrm{x}$ & & & $\mathrm{x}$ \\
\hline & & em lacunas & & $x$ & & & & $\mathrm{x}$ & & $\mathrm{x}$ & $\mathrm{x}$ & & & \\
\hline \multirow{7}{*}{$\begin{array}{l}0 \\
0 \\
\frac{0}{0} \\
\frac{\pi}{0} \\
0 \\
\stackrel{0}{0} \\
\stackrel{0}{0}\end{array}$} & \multirow{3}{*}{ Núcleo } & mitótico & & & & & & & & & & & & \\
\hline & & picnótico & & & & & & & & & & & & \\
\hline & & cariorrexe & & & & & & & & & & & & \\
\hline & \multirow{2}{*}{$\begin{array}{c}\text { Quanto à } \\
\text { disposição }\end{array}$} & em paliçada & $\mathrm{x}$ & $\mathrm{x}$ & $\mathrm{x}$ & & $\mathrm{x}$ & & & $\mathrm{x}$ & & $\mathrm{x}$ & $\mathrm{x}$ & $\mathrm{x}$ \\
\hline & & ao acaso & & & & & & & & & & & & \\
\hline & \multirow{2}{*}{$\begin{array}{c}\text { Quanto à } \\
\text { superfície }\end{array}$} & justapostos & $\mathrm{x}$ & $\mathrm{x}$ & $\mathrm{x}$ & & $\mathrm{x}$ & & & $\mathrm{x}$ & & $\mathrm{x}$ & $\mathrm{x}$ & $\mathrm{x}$ \\
\hline & & à distância & & & & & & & & & & & & \\
\hline \multirow{6}{*}{ 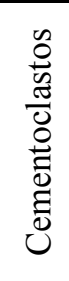 } & \multirow{3}{*}{ Núcleo(s) } & mitótico & & & & & & & & & & & & \\
\hline & & picnótico & & & & & & & & & & & & \\
\hline & & cariorrexe & & & & & & & & & & & & \\
\hline & \multirow{3}{*}{$\begin{array}{l}\text { Quanto à } \\
\text { superfície }\end{array}$} & à distância & & & & & & & & & & & & \\
\hline & & justapostos & & & & & & $\mathrm{x}$ & & & $\mathrm{x}$ & & $\mathrm{x}$ & \\
\hline & & em lacunas & & & & & & $\mathrm{x}$ & & & $\mathrm{x}$ & & & \\
\hline
\end{tabular}

T - total; X - presença; c/ - com; s/ - sem; reabs - reabsorção; CGMN - células gigantes multinucleadas. 
Anexo 6 - Distribuição dos achados microscópicos referentes aos fenômenos morfologicamente detectados nos animais do Grupo C-6

\begin{tabular}{|c|c|c|c|c|c|c|c|c|c|c|c|c|c|c|}
\hline \multirow{3}{*}{\multicolumn{3}{|c|}{ Espéc }} & \multicolumn{6}{|c|}{ ÁREA DE PRESSÃO } & \multicolumn{6}{|c|}{ ÁREA DE TENSÃO } \\
\hline & & & \multicolumn{3}{|c|}{ raiz mesial } & \multicolumn{3}{|c|}{ Raiz distal } & \multicolumn{3}{|c|}{ Raiz distal } & \multicolumn{3}{|c|}{ Raiz mesial } \\
\hline & & & $\begin{array}{c}1 \\
16 \\
\end{array}$ & $\begin{array}{c}2 \\
17 \\
\end{array}$ & $\begin{array}{c}3 \\
18 \\
\end{array}$ & $\begin{array}{c}1 \\
16 \\
\end{array}$ & $\begin{array}{c}2 \\
17 \\
\end{array}$ & $\begin{array}{c}3 \\
18 \\
\end{array}$ & $\begin{array}{c}1 \\
16 \\
\end{array}$ & $\begin{array}{c}2 \\
17 \\
\end{array}$ & $\begin{array}{c}3 \\
18 \\
\end{array}$ & $\begin{array}{c}1 \\
16 \\
\end{array}$ & $\begin{array}{c}2 \\
17 \\
\end{array}$ & $\begin{array}{c}3 \\
18 \\
\end{array}$ \\
\hline \multirow{21}{*}{ 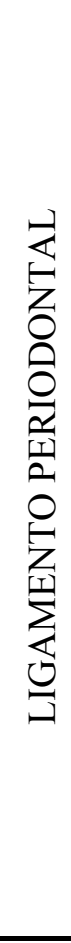 } & \multirow{2}{*}{ Largura } & aumentada & & & & & & & & & & & & \\
\hline & & diminuída & & & & & & & & & & & & \\
\hline & \multirow{2}{*}{$\begin{array}{c}\text { Fibras } \\
\text { colágenas }\end{array}$} & perpendiculares & $\mathrm{x}$ & $\mathrm{x}$ & $\mathrm{x}$ & & $\mathrm{x}$ & $\mathrm{x}$ & & $\mathrm{x}$ & $\mathrm{x}$ & $\mathrm{x}$ & $\mathrm{x}$ & $\mathrm{x}$ \\
\hline & & ao acaso & & & & & & $\mathrm{x}$ & & & $\mathrm{x}$ & & & \\
\hline & \multirow{3}{*}{$\begin{array}{l}\text { Áreas } \\
\text { hialinas }\end{array}$} & pequenas & $\mathrm{x}$ & & $\mathrm{x}$ & & & & & $\mathrm{x}$ & & & & $\mathrm{x}$ \\
\hline & & Médias & & & & & & & & & & & & \\
\hline & & Grandes & & & & & & & & & & & & \\
\hline & \multirow{4}{*}{$\begin{array}{c}\text { Vasos } \\
\text { sangüíneos }\end{array}$} & normais & $\mathrm{x}$ & $\mathrm{x}$ & $\mathrm{x}$ & & $\mathrm{x}$ & & & $\mathrm{x}$ & & $\mathrm{x}$ & & $\mathrm{x}$ \\
\hline & & comprimidos & & & & & & $\mathrm{x}$ & & & $\mathrm{x}$ & & & \\
\hline & & colabados & & & & & & & & & & & & \\
\hline & & dilatados & & & & & $\mathrm{x}$ & & & & & & $\mathrm{x}$ & \\
\hline & \multirow{4}{*}{$\begin{array}{l}\text { Alterações } \\
\text { circulatórias }\end{array}$} & congestão & $\mathrm{x}$ & $\mathrm{x}$ & $\mathrm{x}$ & & $\mathrm{x}$ & $\mathrm{x}$ & & $\mathrm{x}$ & $\mathrm{x}$ & $\mathrm{x}$ & $\mathrm{x}$ & $\mathrm{x}$ \\
\hline & & exsudato & & & & & & & & & & & $\mathrm{x}$ & \\
\hline & & trombose & & & & & & & & & & & & \\
\hline & & hemorragia & & & & & $\mathrm{x}$ & $\mathrm{x}$ & & & $\mathrm{x}$ & & & $\mathrm{x}$ \\
\hline & \multirow{5}{*}{$\begin{array}{l}\text { Infiltrado } \\
\text { inflamatório }\end{array}$} & neutrófilos & & & $\mathrm{x}$ & & $\mathrm{x}$ & & & & & $\mathrm{x}$ & & $\mathrm{x}$ \\
\hline & & macrófagos & $\mathrm{x}$ & $\mathrm{x}$ & $\mathrm{x}$ & & $\mathrm{x}$ & $x$ & & & $\mathrm{x}$ & $\mathrm{x}$ & & $\mathrm{x}$ \\
\hline & & plasmócitos & & & & & & & & & & & & \\
\hline & & linfócitos & $\mathrm{x}$ & $\mathrm{x}$ & $\mathrm{x}$ & & $\mathrm{x}$ & $\mathrm{x}$ & & $\mathrm{x}$ & $\mathrm{x}$ & $\mathrm{x}$ & & $\mathrm{x}$ \\
\hline & & CGMN & $\mathrm{x}$ & $\mathrm{x}$ & $\mathrm{x}$ & & $\mathrm{x}$ & $\mathrm{x}$ & & $\mathrm{x}$ & $\mathrm{x}$ & & & $\mathrm{x}$ \\
\hline & \multicolumn{2}{|c|}{ Restos epiteliais de Malassez } & & & & & & & & & & & & \\
\hline \multirow{10}{*}{ 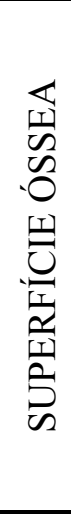 } & \multirow{4}{*}{$\begin{array}{c}\text { Face } \\
\text { periodontal }\end{array}$} & irregular c/ reabs & & $\mathrm{x}$ & & & & $\mathrm{x}$ & & $\bar{x}$ & $x$ & & & \\
\hline & & irregular s/ reabs & $\mathrm{x}$ & $\mathrm{x}$ & $\mathrm{x}$ & & & & & $\mathrm{x}$ & & & & $\mathrm{x}$ \\
\hline & & linha de reversão & $\mathrm{x}$ & $\mathrm{x}$ & & & & $\mathrm{x}$ & & $\mathrm{x}$ & $\mathrm{x}$ & & & \\
\hline & & osteóide & & & $\mathrm{x}$ & & & & & & & & & $\mathrm{x}$ \\
\hline & \multirow{4}{*}{$\begin{array}{c}\text { Face } \\
\text { endosteal }\end{array}$} & irregular c/ reabs & & & & & & & & & & & & \\
\hline & & irregular s/ reabs & & & & & $\mathrm{x}$ & & & & & $\mathrm{x}$ & $\mathrm{x}$ & \\
\hline & & linha de reversão & & & & & $\mathrm{x}$ & & & & & $\mathrm{x}$ & & \\
\hline & & osteóide & & & & & & & & & & & $\mathrm{x}$ & \\
\hline & \multirow{2}{*}{ Crista óssea } & regular & $\mathrm{x}$ & & $\mathrm{x}$ & & & & & $\mathrm{x}$ & & $\mathrm{x}$ & $\mathrm{x}$ & $\mathrm{x}$ \\
\hline & & irregular & & & & & & & & & & & & \\
\hline \multirow{5}{*}{ 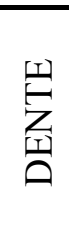 } & \multirow{4}{*}{$\begin{array}{l}\text { Superfície } \\
\text { cementária }\end{array}$} & regular & $\mathrm{x}$ & $\mathrm{x}$ & & & $\bar{x}$ & & & $\mathrm{x}$ & & & $\mathrm{x}$ & \\
\hline & & irregular s/ reabs & & $\mathrm{x}$ & $\mathrm{x}$ & & & & & $\mathrm{x}$ & & & & $\mathrm{x}$ \\
\hline & & irregular c/ reabs & & & & & & $\mathrm{x}$ & & & $\mathrm{x}$ & & & \\
\hline & & Cementóide & & $\mathrm{x}$ & & & & $\mathrm{x}$ & & $\mathrm{x}$ & $\mathrm{x}$ & $\mathrm{x}$ & & $\mathrm{x}$ \\
\hline & \multicolumn{2}{|c|}{ Reabsorção dentinária externa } & & & & & & & & & & $\mathrm{x}$ & & \\
\hline
\end{tabular}




\begin{tabular}{|c|c|c|c|c|c|c|c|c|c|c|c|c|c|c|}
\hline \multicolumn{3}{|c|}{$\begin{array}{ll}\text { Fenômenos } & \text { Espécimes } \\
\end{array}$} & $\begin{array}{c}1 \\
16 \\
\end{array}$ & $\begin{array}{c}2 \\
17 \\
\end{array}$ & $\begin{array}{c}3 \\
18 \\
\end{array}$ & $\begin{array}{c}1 \\
16 \\
\end{array}$ & $\begin{array}{c}2 \\
17 \\
\end{array}$ & $\begin{array}{c}3 \\
18 \\
\end{array}$ & $\begin{array}{c}1 \\
16 \\
\end{array}$ & $\begin{array}{c}2 \\
17 \\
\end{array}$ & $\begin{array}{c}3 \\
18 \\
\end{array}$ & $\begin{array}{c}1 \\
16 \\
\end{array}$ & $\begin{array}{c}2 \\
17 \\
\end{array}$ & $\begin{array}{c}3 \\
18 \\
\end{array}$ \\
\hline \multirow{5}{*}{ 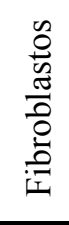 } & \multirow{3}{*}{ Núcleo } & mitótico & & & & & & & & & & & & \\
\hline & & picnótico & & & & & & $\mathrm{x}$ & & & $\mathrm{x}$ & $\mathrm{x}$ & & \\
\hline & & cariorrexe & & & & & & & & & & & & \\
\hline & \multirow{2}{*}{$\begin{array}{c}\text { Quanto à } \\
\text { disposição }\end{array}$} & fasciculado & $\mathrm{x}$ & $\mathrm{x}$ & $\mathrm{x}$ & & $\mathrm{x}$ & $\mathrm{x}$ & & & $\mathrm{x}$ & & $\mathrm{x}$ & $x$ \\
\hline & & ao acaso & & & & & & $\mathrm{x}$ & & & $\mathrm{x}$ & & & \\
\hline \multirow{7}{*}{$\begin{array}{l}\frac{n}{0} \\
\frac{\pi}{0} \\
\frac{\pi}{0} \\
0 \\
\frac{d}{0} \\
0\end{array}$} & \multirow{3}{*}{ Núcleo } & mitótico & & & & & & & & & & & & \\
\hline & & picnótico & & & & & & & & & & & & \\
\hline & & cariorrexe & & & & & & & & & & & & \\
\hline & \multirow{2}{*}{$\begin{array}{c}\text { Quanto à } \\
\text { disposição }\end{array}$} & fasciculado & $\mathrm{x}$ & $\mathrm{x}$ & $\mathrm{x}$ & & $\mathrm{x}$ & $\mathrm{x}$ & & & $\mathrm{x}$ & $\mathrm{x}$ & $\mathrm{x}$ & $\mathrm{x}$ \\
\hline & & ao acaso & & & & & & $\mathrm{x}$ & & & $\mathrm{x}$ & & & \\
\hline & \multirow{2}{*}{$\begin{array}{l}\text { Quanto à } \\
\text { superfície }\end{array}$} & justapostos & $\mathrm{x}$ & $\mathrm{x}$ & $\mathrm{x}$ & & $\mathrm{x}$ & $\mathrm{x}$ & & & $\mathrm{x}$ & $\mathrm{x}$ & $\mathrm{x}$ & $\mathrm{x}$ \\
\hline & & à distância & & & & & & & & & & & & \\
\hline \multirow{6}{*}{$\begin{array}{l}0 \\
0 \\
\frac{0}{0} \\
\frac{\pi}{0} \\
0 \\
\frac{D}{n} \\
0\end{array}$} & \multirow{3}{*}{ Núcleo(s) } & mitótico & & & & & & & & & & & & \\
\hline & & picnótico & & & & & & & & & & & & \\
\hline & & cariorrexe & & & & & & & & & & & & \\
\hline & \multirow{3}{*}{$\begin{array}{c}\text { Quanto à } \\
\text { superfície }\end{array}$} & à distância & & & & & & & & & & & & \\
\hline & & justapostos & $\mathrm{x}$ & $\mathrm{x}$ & $\mathrm{x}$ & & $\mathrm{x}$ & $\mathrm{x}$ & & $\mathrm{x}$ & $\mathrm{x}$ & & & $\mathrm{x}$ \\
\hline & & em lacunas & & $x$ & & & & $\mathrm{x}$ & & $\mathrm{x}$ & $\mathrm{x}$ & & & \\
\hline \multirow{7}{*}{$\begin{array}{l}0 \\
0 \\
\frac{0}{0} \\
\frac{\pi}{0} \\
0 \\
\stackrel{0}{0} \\
\stackrel{0}{0}\end{array}$} & \multirow{3}{*}{ Núcleo } & mitótico & & & & & & & & & & & & \\
\hline & & picnótico & & & & & & & & & & & & \\
\hline & & cariorrexe & & & & & & & & & & & & \\
\hline & \multirow{2}{*}{$\begin{array}{c}\text { Quanto à } \\
\text { disposição }\end{array}$} & em paliçada & $\mathrm{x}$ & $\mathrm{x}$ & $\mathrm{x}$ & & $\mathrm{x}$ & & & $\mathrm{x}$ & & $\mathrm{x}$ & $\mathrm{x}$ & $\mathrm{x}$ \\
\hline & & ao acaso & & & & & & & & & & & & \\
\hline & \multirow{2}{*}{$\begin{array}{c}\text { Quanto à } \\
\text { superfície }\end{array}$} & justapostos & $\mathrm{x}$ & $\mathrm{x}$ & $\mathrm{x}$ & & $\mathrm{x}$ & & & $\mathrm{x}$ & & $\mathrm{x}$ & $\mathrm{x}$ & $\mathrm{x}$ \\
\hline & & à distância & & & & & & & & & & & & \\
\hline \multirow{6}{*}{ 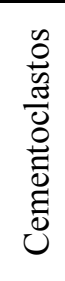 } & \multirow{3}{*}{ Núcleo(s) } & mitótico & & & & & & & & & & & & \\
\hline & & picnótico & & & & & & & & & & & & \\
\hline & & cariorrexe & & & & & & & & & & & & \\
\hline & \multirow{3}{*}{$\begin{array}{l}\text { Quanto à } \\
\text { superfície }\end{array}$} & à distância & & & & & & & & & & & & \\
\hline & & justapostos & & & & & & $\mathrm{x}$ & & & $x$ & & $\mathrm{x}$ & \\
\hline & & em lacunas & & & & & & $\mathrm{x}$ & & & $\mathrm{x}$ & & & \\
\hline
\end{tabular}

T - total; X - presença; c/ - com; s/ - sem; reabs - reabsorção; CGMN - células gigantes multinucleadas. 
Anexo 7 - Distribuição dos achados microscópicos referentes aos fenômenos morfologicamente detectados nos animais do Grupo C-7

\begin{tabular}{|c|c|c|c|c|c|c|c|c|c|c|c|c|c|c|}
\hline \multirow{3}{*}{\multicolumn{3}{|c|}{ Espécimes }} & \multicolumn{6}{|c|}{ ÁREA DE PRESSÃO } & \multicolumn{6}{|c|}{ ÁREA DE TENSÃO } \\
\hline & & & \multicolumn{3}{|c|}{ raiz mesial } & \multicolumn{3}{|c|}{ Raiz distal } & \multicolumn{3}{|c|}{ Raiz distal } & \multicolumn{3}{|c|}{ Raiz mesial } \\
\hline & & & $\begin{array}{c}1 \\
19 \\
\end{array}$ & $\begin{array}{c}2 \\
20 \\
\end{array}$ & $\begin{array}{c}3 \\
21 \\
\end{array}$ & $\begin{array}{c}1 \\
19 \\
\end{array}$ & $\begin{array}{c}2 \\
20 \\
\end{array}$ & $\begin{array}{c}3 \\
21 \\
\end{array}$ & $\begin{array}{c}1 \\
19 \\
\end{array}$ & $\begin{array}{c}2 \\
20 \\
\end{array}$ & $\begin{array}{c}3 \\
21 \\
\end{array}$ & $\begin{array}{c}1 \\
19 \\
\end{array}$ & $\begin{array}{c}2 \\
20 \\
\end{array}$ & $\begin{array}{c}3 \\
21 \\
\end{array}$ \\
\hline \multirow{21}{*}{ 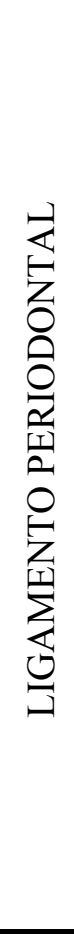 } & \multirow{2}{*}{ Largura } & aumentada & & & & & & & & & & & & \\
\hline & & diminuída & & & & & & & & & & & & \\
\hline & \multirow{2}{*}{$\begin{array}{l}\text { Fibras } \\
\text { colágenas }\end{array}$} & perpendiculares & & & $\mathrm{x}$ & & & $\mathrm{x}$ & & & $\mathrm{x}$ & & & $\mathrm{x}$ \\
\hline & & ao acaso & & & & & & $\mathrm{x}$ & & & $\mathrm{x}$ & & & \\
\hline & \multirow{3}{*}{$\begin{array}{c}\text { Áreas } \\
\text { hialinas }\end{array}$} & pequenas & & & $\mathrm{x}$ & & & & & & & & & $\mathrm{x}$ \\
\hline & & Médias & & & & & & & & & & & & \\
\hline & & Grandes & & & & & & & & & & & & \\
\hline & \multirow{4}{*}{$\begin{array}{c}\text { Vasos } \\
\text { sangüíneos }\end{array}$} & normais & & & $\mathrm{x}$ & & & & & & & & & $\mathrm{x}$ \\
\hline & & comprimidos & & & & & & $\mathrm{x}$ & & & $\mathrm{x}$ & & & \\
\hline & & colabados & & & & & & & & & & & & \\
\hline & & dilatados & & & & & & & & & & & & \\
\hline & \multirow{4}{*}{$\begin{array}{l}\text { Alterações } \\
\text { circulatórias }\end{array}$} & congestão & & & $\mathrm{x}$ & & & $\mathrm{x}$ & & & $\mathrm{x}$ & & & $\mathrm{x}$ \\
\hline & & exsudato & & & & & & & & & & & & \\
\hline & & trombose & & & & & & & & & & & & \\
\hline & & hemorragia & & & & & & $\mathrm{x}$ & & & $\mathrm{x}$ & & & $\mathrm{x}$ \\
\hline & \multirow{5}{*}{$\begin{array}{l}\text { Infiltrado } \\
\text { inflamatório }\end{array}$} & neutrófilos & & & $\mathrm{x}$ & & & & & & & & & $\mathrm{x}$ \\
\hline & & macrófagos & & & $\mathrm{x}$ & & & $\mathrm{x}$ & & & $\mathrm{x}$ & & & $\mathrm{x}$ \\
\hline & & plasmócitos & & & & & & & & & & & & \\
\hline & & linfócitos & & & $\mathrm{x}$ & & & $\mathrm{x}$ & & & $\mathrm{x}$ & & & $\mathrm{x}$ \\
\hline & & CGMN & & & $\mathrm{x}$ & & & $\mathrm{x}$ & & & $\mathrm{x}$ & & & $\mathrm{x}$ \\
\hline & \multicolumn{2}{|c|}{ Restos epiteliais de Malassez } & & & & & & & & & & & & \\
\hline \multirow{10}{*}{ 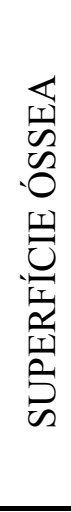 } & \multirow{4}{*}{$\begin{array}{c}\text { Face } \\
\text { periodontal }\end{array}$} & irregular c/ reabs & & & & & & $\mathrm{x}$ & & & $\mathrm{x}$ & & & \\
\hline & & irregular s/ reabs & & & $\mathrm{x}$ & & & & & & & & & $\mathrm{x}$ \\
\hline & & linha de reversão & & & & & & $\mathrm{x}$ & & & $\mathrm{x}$ & & & \\
\hline & & osteóide & & & $\mathrm{x}$ & & & & & & & & & $\mathrm{x}$ \\
\hline & \multirow{4}{*}{$\begin{array}{c}\text { Face } \\
\text { endosteal }\end{array}$} & irregular c/ reabs & & & & & & & & & & & & \\
\hline & & irregular s/ reabs & & & & & & & & & & & & \\
\hline & & linha de reversão & & & & & & & & & & & & \\
\hline & & osteóide & & & & & & & & & & & & \\
\hline & \multirow{2}{*}{ Crista óssea } & regular & & & $\mathrm{x}$ & & & & & & & & & $\mathrm{x}$ \\
\hline & & irregular & & & & & & & & & & & & \\
\hline \multirow{5}{*}{ 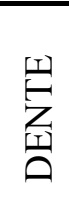 } & \multirow{4}{*}{$\begin{array}{l}\text { Superfície } \\
\text { cementária }\end{array}$} & regular & & & & & & & & & & & & \\
\hline & & irregular s/ reabs & & & $\mathrm{x}$ & & & & & & & & & $\mathrm{x}$ \\
\hline & & irregular c/ reabs & & & & & & $\mathrm{x}$ & & & $\mathrm{x}$ & & & \\
\hline & & Cementóide & & & & & & $\mathrm{x}$ & & & $\mathrm{x}$ & & & $\mathrm{x}$ \\
\hline & \multicolumn{2}{|c|}{ Reabsorção dentinária externa } & & & & & & & & & & & & \\
\hline
\end{tabular}




\begin{tabular}{|c|c|c|c|c|c|c|c|c|c|c|c|c|c|c|}
\hline \multicolumn{3}{|c|}{$\begin{array}{ll}\text { Fenômenos } & \text { Espécimes } \\
\end{array}$} & $\begin{array}{c}1 \\
19 \\
\end{array}$ & $\begin{array}{c}2 \\
20 \\
\end{array}$ & $\begin{array}{c}3 \\
21 \\
\end{array}$ & $\begin{array}{c}1 \\
19 \\
\end{array}$ & $\begin{array}{c}2 \\
20 \\
\end{array}$ & $\begin{array}{c}3 \\
21 \\
\end{array}$ & $\begin{array}{c}1 \\
19 \\
\end{array}$ & $\begin{array}{c}2 \\
20 \\
\end{array}$ & $\begin{array}{c}3 \\
21 \\
\end{array}$ & $\begin{array}{c}1 \\
19\end{array}$ & $\begin{array}{c}2 \\
20\end{array}$ & $\begin{array}{c}3 \\
21\end{array}$ \\
\hline \multirow{5}{*}{ 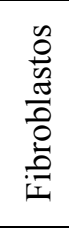 } & \multirow{3}{*}{ Núcleo } & mitótico & & & & & & & & & & & & \\
\hline & & picnótico & & & & & & $\mathrm{x}$ & & & $\mathrm{x}$ & & & \\
\hline & & cariorrexe & & & & & & & & & & & & \\
\hline & \multirow{2}{*}{$\begin{array}{c}\text { Quanto à } \\
\text { disposição }\end{array}$} & fasciculado & & & $\mathrm{x}$ & & & $\mathrm{x}$ & & & $\mathrm{x}$ & & & $x$ \\
\hline & & ao acaso & & & & & & $x$ & & & $\mathrm{x}$ & & & \\
\hline \multirow{7}{*}{$\begin{array}{l}\frac{n}{0} \\
\frac{\pi}{0} \\
\frac{\pi}{0} \\
0 \\
\frac{d}{0} \\
0\end{array}$} & \multirow{3}{*}{ Núcleo } & mitótico & & & & & & & & & & & & \\
\hline & & picnótico & & & & & & & & & & & & \\
\hline & & cariorrexe & & & & & & & & & & & & \\
\hline & \multirow{2}{*}{$\begin{array}{c}\text { Quanto à } \\
\text { disposição }\end{array}$} & fasciculado & & & $\mathrm{x}$ & & & $\mathrm{x}$ & & & $\mathrm{x}$ & & & $\mathrm{x}$ \\
\hline & & ao acaso & & & & & & $x$ & & & $\mathrm{x}$ & & & \\
\hline & \multirow{2}{*}{$\begin{array}{l}\text { Quanto à } \\
\text { superfície }\end{array}$} & justapostos & & & $\mathrm{x}$ & & & $x$ & & & $\mathrm{x}$ & & & $\mathrm{x}$ \\
\hline & & à distância & & & & & & & & & & & & \\
\hline \multirow{6}{*}{$\begin{array}{l}0 \\
0 \\
\frac{0}{0} \\
\frac{\pi}{0} \\
0 \\
\frac{D}{n} \\
0\end{array}$} & \multirow{3}{*}{ Núcleo(s) } & mitótico & & & & & & & & & & & & \\
\hline & & picnótico & & & & & & & & & & & & \\
\hline & & cariorrexe & & & & & & & & & & & & \\
\hline & \multirow{3}{*}{$\begin{array}{c}\text { Quanto à } \\
\text { superfície }\end{array}$} & à distância & & & & & & & & & & & & \\
\hline & & justapostos & & & $\mathrm{x}$ & & & $\mathrm{x}$ & & & $x$ & & & $\mathrm{x}$ \\
\hline & & em lacunas & & & & & & $x$ & & & $\mathrm{x}$ & & & \\
\hline \multirow{7}{*}{$\begin{array}{l}0 \\
0 \\
\frac{0}{0} \\
\frac{\pi}{0} \\
0 \\
\stackrel{0}{0} \\
\stackrel{0}{0}\end{array}$} & \multirow{3}{*}{ Núcleo } & mitótico & & & & & & & & & & & & \\
\hline & & picnótico & & & & & & & & & & & & \\
\hline & & cariorrexe & & & & & & & & & & & & \\
\hline & \multirow{2}{*}{$\begin{array}{c}\text { Quanto à } \\
\text { disposição }\end{array}$} & em paliçada & & & $\mathrm{x}$ & & & & & & & & & $\mathrm{x}$ \\
\hline & & ao acaso & & & & & & & & & & & & \\
\hline & \multirow{2}{*}{$\begin{array}{c}\text { Quanto à } \\
\text { superfície }\end{array}$} & justapostos & & & $\mathrm{x}$ & & & & & & & & & $\mathrm{x}$ \\
\hline & & à distância & & & & & & & & & & & & \\
\hline \multirow{6}{*}{ 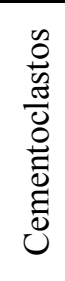 } & \multirow{3}{*}{ Núcleo(s) } & mitótico & & & & & & & & & & & & \\
\hline & & picnótico & & & & & & & & & & & & \\
\hline & & cariorrexe & & & & & & & & & & & & \\
\hline & \multirow{3}{*}{$\begin{array}{l}\text { Quanto à } \\
\text { superfície }\end{array}$} & à distância & & & & & & & & & & & & \\
\hline & & justapostos & & & & & & $\mathrm{x}$ & & & $x$ & & & \\
\hline & & em lacunas & & & & & & $\mathrm{x}$ & & & $\mathrm{x}$ & & & \\
\hline
\end{tabular}

T - total; X - presença; c/ - com; s/ - sem; reabs - reabsorção; CGMN - células gigantes multinucleadas. 
Anexo 8 - Distribuição dos achados microscópicos referentes aos fenômenos morfologicamente detectados nos animais do Grupo E-1

\begin{tabular}{|c|c|c|c|c|c|c|c|c|c|c|c|c|c|c|}
\hline \multirow{3}{*}{\multicolumn{3}{|c|}{$F$}} & \multicolumn{6}{|c|}{ ÁREA DE PRESSÃO } & \multicolumn{6}{|c|}{ ÁREA DE TENSÃO } \\
\hline & & & \multicolumn{3}{|c|}{ raiz mesial } & \multicolumn{3}{|c|}{ Raiz distal } & \multicolumn{3}{|c|}{ Raiz distal } & \multicolumn{3}{|c|}{ Raiz mesial } \\
\hline & & & 1 & 2 & 3 & 1 & 2 & 3 & 1 & 2 & 3 & 1 & 2 & 3 \\
\hline \multicolumn{3}{|c|}{ Fenômenos } & 1 & 2 & 3 & 1 & 2 & 3 & 1 & 2 & 3 & 1 & 2 & 3 \\
\hline \multirow{21}{*}{ 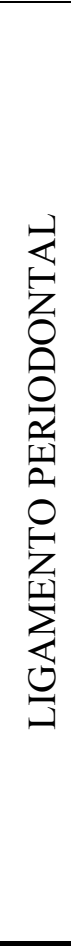 } & \multirow{2}{*}{ Largura } & aumentada & & & & & & & $\mathrm{x}$ & $\mathrm{x}$ & $\mathrm{x}$ & $\mathrm{x}$ & $\mathrm{x}$ & $\mathrm{x}$ \\
\hline & & diminuída & $\mathrm{x}$ & $\mathrm{x}$ & $\mathrm{x}$ & $\mathrm{x}$ & & $\mathrm{x}$ & & & & & & \\
\hline & \multirow{2}{*}{$\begin{array}{c}\text { Fibras } \\
\text { colágenas }\end{array}$} & perpendiculares & $\mathrm{x}$ & $\mathrm{x}$ & $\mathrm{x}$ & & & & $\mathrm{x}$ & $\mathrm{x}$ & $\mathrm{x}$ & $\mathrm{x}$ & $\mathrm{x}$ & $\mathrm{x}$ \\
\hline & & ao acaso & & & & $\mathrm{x}$ & & $\mathrm{x}$ & & & & & & $\mathrm{x}$ \\
\hline & \multirow{3}{*}{$\begin{array}{c}\text { Áreas } \\
\text { hialinas }\end{array}$} & pequenas & $\mathrm{x}$ & $\mathrm{x}$ & & & & $\mathrm{x}$ & $\mathrm{x}$ & $\mathrm{x}$ & $\mathrm{x}$ & $\mathrm{x}$ & $\mathrm{x}$ & $\mathrm{x}$ \\
\hline & & Médias & & & & & & & & & & & & \\
\hline & & Grandes & & & & & & & & & & & & \\
\hline & \multirow{4}{*}{$\begin{array}{c}\text { Vasos } \\
\text { sangüíneos }\end{array}$} & normais & $\mathrm{x}$ & $\mathrm{x}$ & $\mathrm{x}$ & & $\mathrm{x}$ & $\mathrm{x}$ & $\mathrm{x}$ & $\mathrm{x}$ & $\mathrm{x}$ & $\mathrm{x}$ & $\mathrm{x}$ & $\mathrm{x}$ \\
\hline & & comprimidos & $\mathrm{x}$ & & $\mathrm{x}$ & $\mathrm{x}$ & & & & & & & & $\mathrm{x}$ \\
\hline & & colabados & & & & & & & & & & & & \\
\hline & & dilatados & & & & & & & & & & & & \\
\hline & \multirow{4}{*}{$\begin{array}{l}\text { Alterações } \\
\text { circulatórias }\end{array}$} & congestão & $\mathrm{x}$ & $\mathrm{x}$ & $\mathrm{x}$ & $\mathrm{x}$ & $\mathrm{x}$ & $\mathrm{x}$ & $\mathrm{x}$ & & $\mathrm{x}$ & $\mathrm{x}$ & $\mathrm{x}$ & $\mathrm{x}$ \\
\hline & & exsudato & & & & $\mathrm{x}$ & $\mathrm{x}$ & & & & & $\mathrm{x}$ & $\mathrm{x}$ & $\mathrm{x}$ \\
\hline & & trombose & & & & & & & & & & & & \\
\hline & & hemorragia & & & $\mathrm{x}$ & & & & & & & & & $\mathrm{x}$ \\
\hline & \multirow{5}{*}{$\begin{array}{l}\text { Infiltrado } \\
\text { inflamatório }\end{array}$} & neutrófilos & $\mathrm{x}$ & $\mathrm{x}$ & & $\mathrm{x}$ & & & $\mathrm{x}$ & & & & & $\mathrm{x}$ \\
\hline & & macrófagos & & & & & & & & & & & & $\mathrm{x}$ \\
\hline & & plasmócitos & & & & & & & & & & & & \\
\hline & & linfócitos & & & & & & & & & & & & $\mathrm{x}$ \\
\hline & & CGMN & $\mathrm{x}$ & & & & & & $\mathrm{x}$ & & & $\mathrm{x}$ & & \\
\hline & \multicolumn{2}{|c|}{ Restos epiteliais de Malassez } & & & & & & & & & & & & \\
\hline \multirow{10}{*}{ 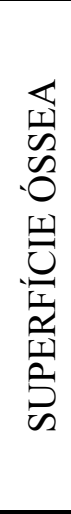 } & \multirow{4}{*}{$\begin{array}{c}\text { Face } \\
\text { periodontal }\end{array}$} & irregular c/ reabs & $\mathrm{x}$ & & & & & & & & & & & \\
\hline & & irregular s/ reabs & $\mathrm{x}$ & $\mathrm{x}$ & $\mathrm{x}$ & & & & $\mathrm{x}$ & $\mathrm{x}$ & $\mathrm{x}$ & & & \\
\hline & & linha de reversão & $\mathrm{x}$ & $\mathrm{x}$ & $\mathrm{x}$ & & & & $\mathrm{x}$ & $\mathrm{x}$ & $\mathrm{x}$ & & & \\
\hline & & osteóide & & & & & & & & & & & & \\
\hline & \multirow{4}{*}{$\begin{array}{c}\text { Face } \\
\text { endosteal }\end{array}$} & irregular c/ reabs & & & & & & & & & & & & \\
\hline & & irregular s/ reabs & & & & $\mathrm{x}$ & $\mathrm{x}$ & $\mathrm{x}$ & & & & $\mathrm{x}$ & $\mathrm{x}$ & $\mathrm{x}$ \\
\hline & & linha de reversão & & & & $\mathrm{x}$ & $\mathrm{x}$ & $\mathrm{x}$ & & & & & $\mathrm{x}$ & $\mathrm{x}$ \\
\hline & & osteóide & & & & & & & & & & & & \\
\hline & \multirow{2}{*}{ Crista óssea } & regular & $\mathrm{x}$ & $\mathrm{x}$ & $\mathrm{x}$ & & & & $\mathrm{x}$ & & $\mathrm{x}$ & $x$ & & $\mathrm{x}$ \\
\hline & & irregular & & & & & & & & & & & & \\
\hline \multirow{5}{*}{ 党 } & \multirow{4}{*}{$\begin{array}{l}\text { Superfície } \\
\text { cementária }\end{array}$} & regular & $\mathrm{x}$ & $\bar{x}$ & & & & & $\bar{x}$ & & $\bar{x}$ & $x$ & $\mathrm{x}$ & $\mathrm{x}$ \\
\hline & & irregular s/ reabs & & & $\mathrm{x}$ & & & & & & & & & \\
\hline & & irregular c/ reabs & & & & & & & $\mathrm{x}$ & & & $\mathrm{x}$ & $\mathrm{x}$ & \\
\hline & & Cementóide & & & & & & & & & $\mathrm{x}$ & & & $\mathrm{x}$ \\
\hline & Reabsorção & entinária externa & & & $\mathrm{x}$ & & & & $\mathrm{x}$ & & & $\mathrm{x}$ & & \\
\hline
\end{tabular}




\begin{tabular}{|c|c|c|c|c|c|c|c|c|c|c|c|c|c|c|}
\hline \multirow{2}{*}{\multicolumn{3}{|c|}{\begin{tabular}{|ll} 
& Espécimes
\end{tabular}}} & 1 & 2 & 3 & 1 & 2 & 3 & 1 & 2 & 3 & 1 & 2 & 3 \\
\hline & & Fenômenos & 1 & 2 & 3 & 1 & 2 & 3 & 1 & 2 & 3 & 1 & 2 & 3 \\
\hline \multirow{5}{*}{$\begin{array}{l}n \\
0 \\
0 \\
\frac{\pi}{0} \\
0 \\
0 \\
0 \\
0\end{array}$} & \multirow{3}{*}{ Núcleo } & mitótico & & & & & & & & & & & & $\mathrm{x}$ \\
\hline & & picnótico & & & & & & & & & & & & \\
\hline & & cariorrexe & & & & & & & & & & & & \\
\hline & \multirow{2}{*}{$\begin{array}{c}\text { Quanto à } \\
\text { disposição }\end{array}$} & fasciculado & $\mathrm{x}$ & $\mathrm{x}$ & $\mathrm{x}$ & $\mathrm{x}$ & $\mathrm{x}$ & $\mathrm{x}$ & $\mathrm{x}$ & $\mathrm{x}$ & $\mathrm{x}$ & $\mathrm{x}$ & $\mathrm{x}$ & $\mathrm{x}$ \\
\hline & & ao acaso & & $\mathrm{x}$ & & $\mathrm{x}$ & & $\mathrm{x}$ & & & & & & $\mathrm{x}$ \\
\hline \multirow{7}{*}{$\begin{array}{l}\frac{n}{0} \\
\frac{\pi}{0} \\
\frac{\pi}{0} \\
0 \\
\frac{d}{0} \\
0\end{array}$} & \multirow{3}{*}{ Núcleo } & mitótico & & & & & & & & & & & & \\
\hline & & picnótico & & & & & & & & & & & & \\
\hline & & cariorrexe & & & & & & & & & & & & \\
\hline & \multirow{2}{*}{$\begin{array}{c}\text { Quanto à } \\
\text { disposição }\end{array}$} & fasciculado & & & $\mathrm{x}$ & & & & & & & & & $\mathrm{x}$ \\
\hline & & ao acaso & $\mathrm{x}$ & & & $\mathrm{x}$ & & & & & & & & \\
\hline & \multirow{2}{*}{$\begin{array}{l}\text { Quanto à } \\
\text { superfície }\end{array}$} & justapostos & & $\mathrm{x}$ & & & $\mathrm{x}$ & $\mathrm{x}$ & $\mathrm{x}$ & & $\mathrm{x}$ & $\mathrm{x}$ & $\mathrm{x}$ & $\mathrm{x}$ \\
\hline & & à distância & & $\mathrm{x}$ & $\mathrm{x}$ & & & & & & & & & \\
\hline \multirow{6}{*}{ 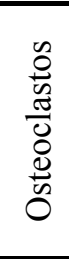 } & \multirow{3}{*}{ Núcleo(s) } & mitótico & & & & & & & & & & & & \\
\hline & & picnótico & & & & & & & & & & & & \\
\hline & & cariorrexe & & & & & & & & & & & & \\
\hline & \multirow{3}{*}{$\begin{array}{l}\text { Quanto à } \\
\text { superfície }\end{array}$} & à distância & & & & & & $\mathrm{x}$ & & & & & & \\
\hline & & justapostos & & & & & & & & & & & & \\
\hline & & em lacunas & $\mathrm{x}$ & & $\mathrm{x}$ & & & $\mathrm{x}$ & $\mathrm{x}$ & & $\mathrm{x}$ & $\mathrm{x}$ & & $\mathrm{x}$ \\
\hline \multirow{7}{*}{$\begin{array}{l}0 \\
0 \\
\frac{0}{0} \\
\frac{\pi}{0} \\
0 \\
\stackrel{0}{0} \\
\stackrel{0}{0}\end{array}$} & \multirow{3}{*}{ Núcleo } & mitótico & & & & & & & & & & & & \\
\hline & & picnótico & & & & & & & & & & & & \\
\hline & & cariorrexe & & & & & & & & & & & & \\
\hline & \multirow{2}{*}{$\begin{array}{c}\text { Quanto à } \\
\text { disposição }\end{array}$} & em paliçada & & & & $\mathrm{x}$ & & & & & & & $\mathrm{x}$ & $\mathrm{x}$ \\
\hline & & ao acaso & & & & & & & & & & & & \\
\hline & \multirow{2}{*}{$\begin{array}{c}\text { Quanto à } \\
\text { superfície }\end{array}$} & justapostos & & $\mathrm{x}$ & & $\mathrm{x}$ & & $\mathrm{x}$ & $\mathrm{x}$ & & $\mathrm{x}$ & $\mathrm{x}$ & $\mathrm{x}$ & $\mathrm{x}$ \\
\hline & & à distância & & & & & & & & & & & & \\
\hline \multirow{6}{*}{ 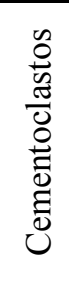 } & \multirow{3}{*}{ Núcleo(s) } & mitótico & & & & & & & & & & & & \\
\hline & & picnótico & & & & & & & & & & & & \\
\hline & & cariorrexe & & & & & & & & & & & & \\
\hline & \multirow{3}{*}{$\begin{array}{l}\text { Quanto à } \\
\text { superfície }\end{array}$} & à distância & & & & & & & & & & & & \\
\hline & & justapostos & $\mathrm{x}$ & & & & & & & & & & & \\
\hline & & em lacunas & & & & & & & $\mathrm{x}$ & & $\mathrm{x}$ & $\mathrm{x}$ & $\mathrm{x}$ & \\
\hline
\end{tabular}

T - total; X - presença; c/ - com; s/ - sem; reabs - reabsorção; CGMN - células gigantes multinucleadas. 
Anexo 9 - Distribuição dos achados microscópicos referentes aos fenômenos morfologicamente detectados nos animais do Grupo E-2

\begin{tabular}{|c|c|c|c|c|c|c|c|c|c|c|c|c|c|c|}
\hline \multirow{3}{*}{\multicolumn{3}{|c|}{ Espéci }} & \multicolumn{6}{|c|}{ ÁREA DE PRESSÃO } & \multicolumn{6}{|c|}{ ÁREA DE TENSÃO } \\
\hline & & & \multicolumn{3}{|c|}{ raiz mesial } & \multicolumn{3}{|c|}{ Raiz distal } & \multicolumn{3}{|c|}{ Raiz distal } & \multicolumn{3}{|c|}{ Raiz mesial } \\
\hline & & & 1 & 2 & 3 & 1 & 2 & 3 & 1 & 2 & 3 & 1 & 2 & 3 \\
\hline \multicolumn{3}{|c|}{ Fenômenos } & 4 & 5 & 6 & 4 & 5 & 6 & 4 & 5 & 6 & 4 & 5 & 6 \\
\hline \multirow{21}{*}{ 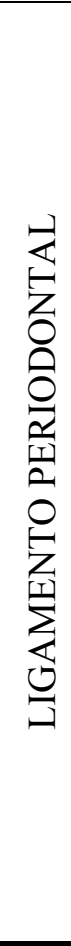 } & \multirow{2}{*}{ Largura } & aumentada & & & & & & & $\mathrm{x}$ & & & $\mathrm{x}$ & & $\mathrm{x}$ \\
\hline & & diminuída & $\mathrm{x}$ & & $\mathrm{x}$ & $\mathrm{x}$ & & & & & & & & \\
\hline & \multirow{2}{*}{$\begin{array}{c}\text { Fibras } \\
\text { colágenas }\end{array}$} & perpendiculares & $\mathrm{x}$ & & $\mathrm{x}$ & & & & $\mathrm{x}$ & & & $\mathrm{x}$ & & $\mathrm{x}$ \\
\hline & & ao acaso & $\mathrm{x}$ & & $\mathrm{x}$ & $\mathrm{x}$ & & & & & & & & \\
\hline & \multirow{3}{*}{$\begin{array}{l}\text { Áreas } \\
\text { hialinas }\end{array}$} & pequenas & $\mathrm{x}$ & & & & & & $\mathrm{x}$ & & & $\mathrm{x}$ & & $\mathrm{x}$ \\
\hline & & Médias & & & $\mathrm{x}$ & $\mathrm{x}$ & & & & & & & & \\
\hline & & Grandes & & & & & & & & & & & & \\
\hline & \multirow{4}{*}{$\begin{array}{c}\text { Vasos } \\
\text { sangüíneos }\end{array}$} & normais & & & & $\mathrm{x}$ & & & $\mathrm{x}$ & & & $\mathrm{x}$ & & \\
\hline & & comprimidos & $\mathrm{x}$ & & $\mathrm{x}$ & $\mathrm{x}$ & & & $\mathrm{x}$ & & & & & $\mathrm{x}$ \\
\hline & & colabados & & & & & & & & & & & & \\
\hline & & dilatados & & & & & & & & & & $\mathrm{x}$ & & \\
\hline & \multirow{4}{*}{$\begin{array}{l}\text { Alterações } \\
\text { circulatórias }\end{array}$} & congestão & $\mathrm{x}$ & & $\mathrm{x}$ & $\mathrm{x}$ & & & $\mathrm{x}$ & & & $\mathrm{x}$ & & $\mathrm{x}$ \\
\hline & & exsudato & & & & $\mathrm{x}$ & & & & & & $\mathrm{x}$ & & \\
\hline & & trombose & & & & & & & & & & & & \\
\hline & & hemorragia & & & & $\mathrm{x}$ & & & $\mathrm{x}$ & & & $\mathrm{x}$ & & \\
\hline & \multirow{5}{*}{$\begin{array}{l}\text { Infiltrado } \\
\text { inflamatório }\end{array}$} & neutrófilos & $\mathrm{x}$ & & & $\mathrm{x}$ & & & $\mathrm{x}$ & & & $\mathrm{x}$ & & $\mathrm{x}$ \\
\hline & & macrófagos & $\mathrm{x}$ & & & $\mathrm{x}$ & & & & & & $\mathrm{x}$ & & $\mathrm{x}$ \\
\hline & & plasmócitos & & & & & & & & & & & & \\
\hline & & linfócitos & $\mathrm{x}$ & & & $\mathrm{x}$ & & & $\mathrm{x}$ & & & $\mathrm{x}$ & & \\
\hline & & CGMN & & & & $\mathrm{x}$ & & & & & & $\mathrm{x}$ & & $\mathrm{x}$ \\
\hline & \multicolumn{2}{|c|}{ Restos epiteliais de Malassez } & & & & & & & & & & & & \\
\hline \multirow{10}{*}{ 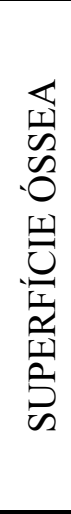 } & \multirow{4}{*}{$\begin{array}{c}\text { Face } \\
\text { periodontal }\end{array}$} & irregular c/ reabs & $\mathrm{x}$ & & $\mathrm{x}$ & & & & & & & & & \\
\hline & & irregular s/ reabs & & & & & & & $\mathrm{x}$ & & & & & \\
\hline & & linha de reversão & $\mathrm{x}$ & & $\mathrm{x}$ & & & & $\mathrm{x}$ & & & & & \\
\hline & & osteóide & & & & & & & & & & & & \\
\hline & \multirow{4}{*}{$\begin{array}{c}\text { Face } \\
\text { endosteal }\end{array}$} & irregular c/ reabs & & & & $\mathrm{x}$ & & & & & & & & $\mathrm{x}$ \\
\hline & & irregular s/ reabs & & & & & & & & & & $\mathrm{x}$ & & $\mathrm{x}$ \\
\hline & & linha de reversão & & & & $\mathrm{x}$ & & & & & & $\mathrm{x}$ & & $\mathrm{x}$ \\
\hline & & osteóide & & & & & & & & & & & & \\
\hline & \multirow{2}{*}{ Crista óssea } & regular & $\mathrm{x}$ & & $\mathrm{x}$ & & & & & & & & & \\
\hline & & irregular & & & & $\mathrm{x}$ & & & & & & $\mathrm{x}$ & & \\
\hline \multirow{5}{*}{ 党 } & \multirow{4}{*}{$\begin{array}{l}\text { Superfície } \\
\text { cementária }\end{array}$} & regular & $\mathrm{x}$ & & & $\mathrm{x}$ & & & & & & $\mathrm{x}$ & & $\mathrm{x}$ \\
\hline & & irregular s/ reabs & & & & & & & & & & & & \\
\hline & & irregular c/ reabs & $\mathrm{x}$ & & $\mathrm{x}$ & $\mathrm{x}$ & & & & & & $\mathrm{x}$ & & \\
\hline & & Cementóide & & & & & & & & & & & & \\
\hline & Reabsorção & entinária externa & & & $\mathrm{x}$ & & & & & & & & & \\
\hline
\end{tabular}




\begin{tabular}{|c|c|c|c|c|c|c|c|c|c|c|c|c|c|c|}
\hline \multirow{2}{*}{\multicolumn{3}{|c|}{\begin{tabular}{|ll} 
& Espécimes
\end{tabular}}} & \multirow{3}{*}{$\begin{array}{l}1 \\
4 \\
\mathrm{x}\end{array}$} & \multirow{3}{*}{$\begin{array}{l}2 \\
5 \\
\end{array}$} & \multirow{3}{*}{$\begin{array}{l}3 \\
6 \\
\end{array}$} & \multirow{3}{*}{$\begin{array}{l}1 \\
4 \\
\end{array}$} & \multirow{3}{*}{$\begin{array}{l}2 \\
5 \\
\end{array}$} & \multirow{3}{*}{$\begin{array}{l}3 \\
6 \\
\end{array}$} & \multirow{3}{*}{$\begin{array}{l}1 \\
4 \\
\end{array}$} & \multirow{3}{*}{$\begin{array}{l}2 \\
5 \\
\end{array}$} & \multirow{3}{*}{$\begin{array}{l}3 \\
6 \\
\end{array}$} & \multirow{3}{*}{$\begin{array}{l}1 \\
4\end{array}$} & \multirow{3}{*}{$\begin{array}{l}2 \\
5 \\
\end{array}$} & \multirow{3}{*}{$\begin{array}{l}3 \\
6 \\
\end{array}$} \\
\hline & & & & & & & & & & & & & & \\
\hline \multirow{5}{*}{ 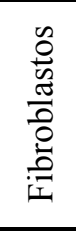 } & \multirow{3}{*}{ Núcleo } & mitótico & & & & & & & & & & & & \\
\hline & & picnótico & & & & $\mathrm{x}$ & & & & & & $\mathrm{x}$ & & \\
\hline & & cariorrexe & & & & $\mathrm{x}$ & & & & & & $\mathrm{x}$ & & \\
\hline & \multirow{2}{*}{$\begin{array}{c}\text { Quanto à } \\
\text { disposição }\end{array}$} & fasciculado & $\mathrm{x}$ & & $\mathrm{x}$ & & & & $\mathrm{x}$ & & & $\mathrm{x}$ & & $\mathrm{x}$ \\
\hline & & ao acaso & $\mathrm{x}$ & & $\mathrm{x}$ & $\mathrm{x}$ & & & & & & & & \\
\hline \multirow{7}{*}{ 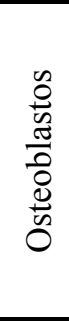 } & \multirow{3}{*}{ Núcleo } & mitótico & & & & & & & & & & & & \\
\hline & & picnótico & & & & & & & & & & & & \\
\hline & & cariorrexe & & & & & & & & & & & & \\
\hline & \multirow{2}{*}{$\begin{array}{c}\text { Quanto à } \\
\text { disposição }\end{array}$} & fasciculado & & & & & & & & & & & & \\
\hline & & ao acaso & $\mathrm{x}$ & & $\mathrm{x}$ & $\mathrm{x}$ & & & $\mathrm{x}$ & & & $\mathrm{x}$ & & $\mathrm{x}$ \\
\hline & \multirow{2}{*}{$\begin{array}{l}\text { Quanto à } \\
\text { superfície }\end{array}$} & justapostos & & & & & & & $\mathrm{x}$ & & & $\mathrm{x}$ & & $\mathrm{x}$ \\
\hline & & à distância & & & & & & & & & & & & \\
\hline \multirow{6}{*}{ 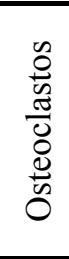 } & \multirow{3}{*}{ Núcleo(s) } & mitótico & & & & & & & & & & & & \\
\hline & & picnótico & & & & & & & & & & & & \\
\hline & & cariorrexe & & & & & & & & & & & & \\
\hline & \multirow{3}{*}{$\begin{array}{c}\text { Quanto à } \\
\text { superfície }\end{array}$} & à distância & & & & $\mathrm{x}$ & & & & & & $\mathrm{x}$ & & \\
\hline & & justapostos & $\mathrm{x}$ & & $\mathrm{x}$ & $\mathrm{x}$ & & & $\mathrm{x}$ & & & & & $\mathrm{x}$ \\
\hline & & em lacunas & & & & & & & & & & & & \\
\hline \multirow{7}{*}{$\begin{array}{l}0 \\
0 \\
\frac{0}{0} \\
\frac{\pi}{0} \\
0 \\
\stackrel{0}{0} \\
\stackrel{0}{0}\end{array}$} & \multirow{3}{*}{ Núcleo } & mitótico & & & & & & & & & & & & \\
\hline & & picnótico & & & & & & & & & & & & \\
\hline & & cariorrexe & & & & & & & & & & & & \\
\hline & Quanto à & em paliçada & $\mathrm{x}$ & & $\mathrm{x}$ & & & & $\mathrm{x}$ & & & $\mathrm{x}$ & & $\mathrm{x}$ \\
\hline & disposição & ao acaso & & & & $\mathrm{x}$ & & & & & & & & \\
\hline & Quanto à & justapostos & $\mathrm{x}$ & & $\mathrm{x}$ & $\mathrm{x}$ & & & $\mathrm{x}$ & & & $\mathrm{x}$ & & $\mathrm{x}$ \\
\hline & superfície & à distância & & & & & & & & & & & & \\
\hline n & & mitótico & & & & & & & & & & & & \\
\hline 总 & Núcleo(s) & picnótico & & & & & & & & & & & & \\
\hline ల̈ & & cariorrexe & & & & & & & & & & & & \\
\hline $\bar{\Xi}$ & & à distância & & & & & & & & & & & & \\
\hline ब & sunerfície & justapostos & & & $\mathrm{x}$ & & & & & & & & & \\
\hline & & em lacunas & & & $\mathrm{x}$ & $\mathrm{x}$ & & & & & & $\mathrm{x}$ & & \\
\hline
\end{tabular}

T - total; X - presença; c/ - com; s/ - sem; reabs - reabsorção; CGMN - células gigantes multinucleadas. 
Anexo 10 - Distribuição dos achados microscópicos referentes aos fenômenos morfologicamente detectados nos animais do Grupo E-3

\begin{tabular}{|c|c|c|c|c|c|c|c|c|c|c|c|c|c|c|}
\hline \multirow{3}{*}{\multicolumn{3}{|c|}{ Fon }} & \multicolumn{6}{|c|}{ ÁREA DE PRESSÃO } & \multicolumn{6}{|c|}{ ÁREA DE TENSÃO } \\
\hline & & & \multicolumn{3}{|c|}{ raiz mesial } & \multicolumn{3}{|c|}{ Raiz distal } & \multicolumn{3}{|c|}{ Raiz distal } & \multicolumn{3}{|c|}{ Raiz mesial } \\
\hline & & & 1 & 2 & 3 & 1 & 2 & 3 & 1 & 2 & 3 & 1 & 2 & 3 \\
\hline \multicolumn{3}{|c|}{ Fenômenos } & 7 & 8 & 9 & 7 & 8 & 9 & 7 & 8 & 9 & 7 & 8 & 9 \\
\hline \multirow{21}{*}{ 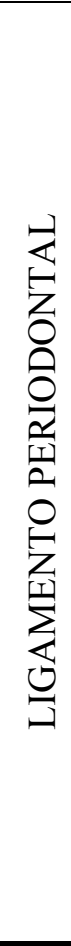 } & \multirow{2}{*}{ Largura } & aumentada & & & & & & & $\mathrm{x}$ & $\mathrm{x}$ & $\mathrm{x}$ & $\mathrm{x}$ & $\mathrm{x}$ & $\mathrm{x}$ \\
\hline & & diminuída & $\mathrm{x}$ & $\mathrm{x}$ & $\mathrm{x}$ & $\mathrm{x}$ & $\mathrm{x}$ & $\mathrm{x}$ & & & & & & \\
\hline & \multirow{2}{*}{$\begin{array}{c}\text { Fibras } \\
\text { colágenas }\end{array}$} & perpendiculares & & & & & & & $\mathrm{x}$ & $\mathrm{x}$ & $\mathrm{x}$ & $\mathrm{x}$ & $\mathrm{x}$ & $\mathrm{x}$ \\
\hline & & ao acaso & $\mathrm{x}$ & $\mathrm{x}$ & $\mathrm{x}$ & $\mathrm{x}$ & $\mathrm{x}$ & $\mathrm{x}$ & & & & & & \\
\hline & \multirow{3}{*}{$\begin{array}{l}\text { Áreas } \\
\text { hialinas }\end{array}$} & pequenas & $\mathrm{x}$ & $\mathrm{x}$ & & $\mathrm{x}$ & & & $\mathrm{x}$ & $\mathrm{x}$ & $\mathrm{x}$ & & & $\mathrm{x}$ \\
\hline & & Médias & & & & & & & & & & & & \\
\hline & & Grandes & & & & & $\mathrm{x}$ & $\mathrm{x}$ & & & & & & \\
\hline & \multirow{4}{*}{$\begin{array}{c}\text { Vasos } \\
\text { sangüíneos }\end{array}$} & normais & & & & $\mathrm{x}$ & & $\mathrm{x}$ & $\mathrm{x}$ & $\mathrm{x}$ & $\mathrm{x}$ & & $\mathrm{x}$ & $\mathrm{x}$ \\
\hline & & comprimidos & $\mathrm{x}$ & $\mathrm{x}$ & $\mathrm{x}$ & $\mathrm{x}$ & $\mathrm{x}$ & $\mathrm{x}$ & & & & & & \\
\hline & & colabados & & & & & & & & & & & & \\
\hline & & dilatados & & & & & & & & & & $\mathrm{x}$ & $\mathrm{x}$ & $\mathrm{x}$ \\
\hline & \multirow{4}{*}{$\begin{array}{l}\text { Alterações } \\
\text { circulatórias }\end{array}$} & congestão & $\mathrm{x}$ & $\mathrm{x}$ & $\mathrm{x}$ & $\mathrm{x}$ & $\mathrm{x}$ & $\mathrm{x}$ & $\mathrm{x}$ & $\mathrm{x}$ & & $\mathrm{x}$ & $\mathrm{x}$ & $\mathrm{x}$ \\
\hline & & exsudato & & & & $\mathrm{x}$ & $\mathrm{x}$ & $\mathrm{x}$ & & $\mathrm{x}$ & & & $\mathrm{x}$ & $\mathrm{x}$ \\
\hline & & trombose & & & & & & & & & & & & \\
\hline & & hemorragia & & & & $\mathrm{x}$ & & $\mathrm{x}$ & & $\mathrm{x}$ & & & $\mathrm{x}$ & $\mathrm{x}$ \\
\hline & \multirow{5}{*}{$\begin{array}{l}\text { Infiltrado } \\
\text { inflamatório }\end{array}$} & neutrófilos & & & & $\mathrm{x}$ & $\mathrm{x}$ & $\mathrm{x}$ & & $\mathrm{x}$ & & & $\mathrm{x}$ & $\mathrm{x}$ \\
\hline & & macrófagos & & & & $\mathrm{x}$ & $\mathrm{x}$ & $\mathrm{x}$ & & & & & & $\mathrm{x}$ \\
\hline & & plasmócitos & & & & & & & & & & & & \\
\hline & & linfócitos & & & & $\mathrm{x}$ & & $\mathrm{x}$ & & $\mathrm{x}$ & & & $\mathrm{x}$ & $\mathrm{x}$ \\
\hline & & CGMN & $\mathrm{x}$ & $\mathrm{x}$ & $\mathrm{x}$ & $\mathrm{x}$ & $\mathrm{x}$ & $\mathrm{x}$ & & $\mathrm{x}$ & & & $\mathrm{x}$ & $\mathrm{x}$ \\
\hline & \multicolumn{2}{|c|}{ Restos epiteliais de Malassez } & & & & & & & & & & & & \\
\hline \multirow{10}{*}{ 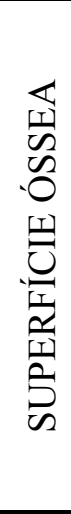 } & \multirow{4}{*}{$\begin{array}{c}\text { Face } \\
\text { periodontal }\end{array}$} & irregular c/ reabs & $\mathrm{x}$ & $\mathrm{x}$ & $\mathrm{x}$ & & & & & $\bar{x}$ & & & & \\
\hline & & irregular s/ reabs & & & & & & & & & & & & \\
\hline & & linha de reversão & $\mathrm{x}$ & $\mathrm{x}$ & $\mathrm{x}$ & & & & $\mathrm{x}$ & & & & & \\
\hline & & osteóide & & & & & & & & & & & & \\
\hline & \multirow{4}{*}{$\begin{array}{c}\text { Face } \\
\text { endosteal }\end{array}$} & irregular c/ reabs & & & & $\mathrm{x}$ & $\mathrm{x}$ & $\mathrm{x}$ & $\mathrm{x}$ & $\mathrm{x}$ & & $\mathrm{x}$ & $\mathrm{x}$ & $\mathrm{x}$ \\
\hline & & irregular s/ reabs & & & & & & & & & & & & \\
\hline & & linha de reversão & & & & $\mathrm{x}$ & & $\mathrm{x}$ & & $\mathrm{x}$ & & $\mathrm{x}$ & $\mathrm{x}$ & $\mathrm{x}$ \\
\hline & & osteóide & & & & & & & & & & & & $\mathrm{x}$ \\
\hline & \multirow{2}{*}{ Crista óssea } & regular & & $\mathrm{x}$ & & & & $\mathrm{x}$ & & & & & & $\mathrm{x}$ \\
\hline & & irregular & $\mathrm{x}$ & & $\mathrm{x}$ & $\mathrm{x}$ & $\mathrm{x}$ & & $\mathrm{x}$ & $\mathrm{x}$ & & $\mathrm{x}$ & $\mathrm{x}$ & \\
\hline \multirow{5}{*}{ 党 } & \multirow{4}{*}{$\begin{array}{l}\text { Superfície } \\
\text { cementária }\end{array}$} & regular & & $\mathrm{x}$ & $\mathrm{x}$ & $\mathrm{x}$ & $\mathrm{x}$ & & & & & $\mathrm{x}$ & $\mathrm{x}$ & $\mathrm{x}$ \\
\hline & & irregular s/ reabs & & & & & & $\mathrm{x}$ & $\mathrm{x}$ & $\mathrm{x}$ & & & & \\
\hline & & irregular c/ reabs & & & & & & & & & & $\mathrm{x}$ & $\mathrm{x}$ & $\mathrm{x}$ \\
\hline & & Cementóide & & & & & & & & & & & & \\
\hline & Reabsorção & entinária externa & & & & & & & & & & & & \\
\hline
\end{tabular}




\begin{tabular}{|c|c|c|c|c|c|c|c|c|c|c|c|c|c|c|}
\hline \multirow{2}{*}{\multicolumn{3}{|c|}{\begin{tabular}{|ll} 
& Espécimes
\end{tabular}}} & \multirow{3}{*}{$\begin{array}{l}1 \\
7\end{array}$} & \multirow{3}{*}{$\begin{array}{l}2 \\
8 \\
\end{array}$} & \multirow{3}{*}{$\begin{array}{l}3 \\
9 \\
\end{array}$} & \multirow{3}{*}{$\begin{array}{l}1 \\
7\end{array}$} & \multirow{3}{*}{$\begin{array}{l}2 \\
8 \\
\end{array}$} & \multirow{3}{*}{$\begin{array}{l}3 \\
9 \\
\times \\
\end{array}$} & \multirow{3}{*}{$\begin{array}{l}1 \\
7 \\
\end{array}$} & \multirow{3}{*}{$\begin{array}{l}2 \\
8 \\
\end{array}$} & \multirow{3}{*}{$\begin{array}{l}3 \\
9 \\
\end{array}$} & \multirow{3}{*}{$\begin{array}{l}1 \\
7\end{array}$} & \multirow{3}{*}{$\begin{array}{l}2 \\
8 \\
\end{array}$} & \multirow{3}{*}{$\begin{array}{l}3 \\
9 \\
x\end{array}$} \\
\hline & & & & & & & & & & & & & & \\
\hline \multirow{5}{*}{$\begin{array}{l}0 \\
0 \\
0 \\
0 \\
0 \\
0 \\
0 \\
0 \\
0\end{array}$} & \multirow{3}{*}{ Núcleo } & mitótico & & & & & & & & & & & & \\
\hline & & picnótico & & & & $\mathrm{x}$ & $\mathrm{x}$ & $\mathrm{x}$ & & & & $\mathrm{x}$ & & $\mathrm{x}$ \\
\hline & & cariorrexe & & & & $\mathrm{x}$ & $\mathrm{x}$ & & & & & $\mathrm{x}$ & & $\mathrm{x}$ \\
\hline & \multirow{2}{*}{$\begin{array}{c}\text { Quanto à } \\
\text { disposição }\end{array}$} & fasciculado & & & & & & & $\mathrm{x}$ & $\mathrm{x}$ & & $\mathrm{x}$ & $\mathrm{x}$ & $\mathrm{x}$ \\
\hline & & ao acaso & $\mathrm{x}$ & $\mathrm{x}$ & $\mathrm{x}$ & $\mathrm{x}$ & $\mathrm{x}$ & $\mathrm{x}$ & & & & & $\mathrm{x}$ & $\mathrm{x}$ \\
\hline \multirow{7}{*}{$\begin{array}{l}\frac{n}{0} \\
\frac{\pi}{0} \\
\frac{\pi}{0} \\
0 \\
\frac{d}{0} \\
0\end{array}$} & \multirow{3}{*}{ Núcleo } & mitótico & & & & & & & & & & & & \\
\hline & & picnótico & & & & $\mathrm{x}$ & & & & & & & & \\
\hline & & cariorrexe & & & & & & & & & & & & \\
\hline & \multirow{2}{*}{$\begin{array}{c}\text { Quanto à } \\
\text { disposição }\end{array}$} & fasciculado & & & & & & & $\mathrm{x}$ & & & & & \\
\hline & & ao acaso & & $\mathrm{x}$ & $\mathrm{x}$ & $\mathrm{x}$ & $\mathrm{x}$ & $\mathrm{x}$ & & & & & $\mathrm{x}$ & $\mathrm{x}$ \\
\hline & \multirow{2}{*}{$\begin{array}{l}\text { Quanto à } \\
\text { superfície }\end{array}$} & justapostos & $\mathrm{x}$ & & & & & & $\mathrm{x}$ & $\mathrm{x}$ & $\mathrm{x}$ & $\mathrm{x}$ & & \\
\hline & & à distância & $\mathrm{x}$ & $\mathrm{x}$ & $\mathrm{x}$ & & $\mathrm{x}$ & & & & & & & \\
\hline \multirow{6}{*}{ 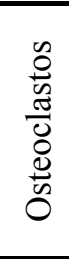 } & \multirow{3}{*}{ Núcleo(s) } & mitótico & & & & & & & & & & & & \\
\hline & & picnótico & & & & & & & & & & & & \\
\hline & & cariorrexe & & & & & & & & & & & & \\
\hline & \multirow{3}{*}{$\begin{array}{c}\text { Quanto à } \\
\text { superfície }\end{array}$} & à distância & & & & $\mathrm{x}$ & $\mathrm{x}$ & $\mathrm{x}$ & & & & $\mathrm{x}$ & $\mathrm{x}$ & $\mathrm{x}$ \\
\hline & & justapostos & & & & & & & & & & & & \\
\hline & & em lacunas & $\mathrm{x}$ & $\mathrm{x}$ & $\mathrm{x}$ & $\mathrm{x}$ & $\mathrm{x}$ & $\mathrm{x}$ & $\mathrm{x}$ & & $\mathrm{x}$ & & $\mathrm{x}$ & $\mathrm{x}$ \\
\hline \multirow{7}{*}{$\begin{array}{l}\frac{0}{0} \\
\frac{\pi}{0} \\
\frac{\pi}{0} \\
0 \\
\stackrel{0}{0} \\
\stackrel{0}{0}\end{array}$} & \multirow{3}{*}{ Núcleo } & mitótico & & & & & & & & & & & & \\
\hline & & picnótico & & & & & & & & & & & & \\
\hline & & cariorrexe & & & & & & & & & & & & \\
\hline & Quanto à & em paliçada & & & & & & & & & & & & \\
\hline & disposição & ao acaso & & & & $\mathrm{x}$ & $\mathrm{x}$ & $\mathrm{x}$ & & & & & & \\
\hline & Quanto à & justapostos & $\mathrm{x}$ & $\mathrm{x}$ & & & & $\mathrm{x}$ & & & & $\mathrm{x}$ & $\mathrm{x}$ & $\mathrm{x}$ \\
\hline & superfície & à distância & & & & & & & & & & & & \\
\hline n & & mitótico & & & & & & & & & & & & \\
\hline 总 & Núcleo(s) & picnótico & & & & & & & & & & & & \\
\hline ల̈ & & cariorrexe & & & & & & & & & & & & \\
\hline $\bar{\Xi}$ & & à distância & & & & & & & & & & & $\mathrm{x}$ & \\
\hline है & sunerfície & justapostos & & & & & & & & & & & & \\
\hline & & em lacunas & & & & & & $\mathrm{x}$ & & & & & & \\
\hline
\end{tabular}

T - total; X - presença; c/ - com; s/ - sem; reabs - reabsorção; CGMN - células gigantes multinucleadas. 
Anexo 11 - Distribuição dos achados microscópicos referentes aos fenômenos morfologicamente detectados nos animais do Grupo E-4

\begin{tabular}{|c|c|c|c|c|c|c|c|c|c|c|c|c|c|c|}
\hline \multirow{3}{*}{\multicolumn{3}{|c|}{ Espécimes }} & \multicolumn{6}{|c|}{ ÁREA DE PRESSÃO } & \multicolumn{6}{|c|}{ ÁREA DE TENSÃO } \\
\hline & & & \multicolumn{3}{|c|}{ raiz mesial } & \multicolumn{3}{|c|}{ Raiz distal } & \multicolumn{3}{|c|}{ Raiz distal } & \multicolumn{3}{|c|}{ Raiz mesial } \\
\hline & & & $\begin{array}{c}1 \\
10\end{array}$ & $\begin{array}{c}2 \\
11\end{array}$ & $\begin{array}{c}3 \\
12\end{array}$ & $\begin{array}{c}1 \\
10\end{array}$ & $\begin{array}{c}2 \\
11\end{array}$ & $\begin{array}{c}3 \\
12\end{array}$ & 1 & $\begin{array}{c}2 \\
11\end{array}$ & $\begin{array}{c}3 \\
12\end{array}$ & $\begin{array}{c}1 \\
10\end{array}$ & $\begin{array}{c}2 \\
11\end{array}$ & $\begin{array}{c}3 \\
12\end{array}$ \\
\hline \multirow{21}{*}{ 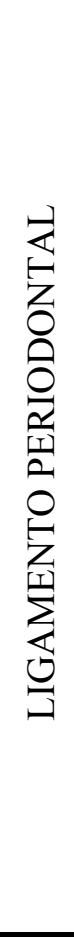 } & \multirow{2}{*}{ Largura } & aumentada & & & & & & & $\mathrm{x}$ & & $\mathrm{x}$ & $\mathrm{x}$ & & $\mathrm{x}$ \\
\hline & & diminuída & $\mathrm{x}$ & & $\mathrm{x}$ & $\mathrm{x}$ & & $\mathrm{x}$ & & & & & & \\
\hline & \multirow{2}{*}{$\begin{array}{l}\text { Fibras } \\
\text { colágenas }\end{array}$} & perpendiculares & $\mathrm{x}$ & & & & & & $\mathrm{x}$ & & $\mathrm{x}$ & & & $\mathrm{x}$ \\
\hline & & ao acaso & $\mathrm{x}$ & & $\mathrm{x}$ & & & & & & & & & $\mathrm{x}$ \\
\hline & \multirow{3}{*}{$\begin{array}{l}\text { Áreas } \\
\text { hialinas }\end{array}$} & pequenas & $\mathrm{x}$ & & & & & & & & $\mathrm{x}$ & & & $x$ \\
\hline & & Médias & & & & & & & & & & & & \\
\hline & & Grandes & $\mathrm{x}$ & & & $\mathrm{x}$ & & $x$ & & & & & & \\
\hline & \multirow{4}{*}{$\begin{array}{c}\text { Vasos } \\
\text { sangüíneos }\end{array}$} & normais & & & & & & & $x$ & & & $\mathrm{x}$ & & \\
\hline & & comprimidos & $\mathrm{x}$ & & $\mathrm{x}$ & & & $\mathrm{x}$ & $\mathrm{x}$ & & & & & \\
\hline & & colabados & & & & & & & & & & & & \\
\hline & & dilatados & & & & & & $\mathrm{x}$ & & & $\mathrm{x}$ & & & $\mathrm{x}$ \\
\hline & \multirow{4}{*}{$\begin{array}{l}\text { Alterações } \\
\text { circulatórias }\end{array}$} & congestão & $\mathrm{x}$ & & $\mathrm{x}$ & & & $\mathrm{x}$ & $x$ & & $\mathrm{x}$ & $\mathrm{x}$ & & $\mathrm{x}$ \\
\hline & & exsudato & & & & & & & & & & & & \\
\hline & & trombose & & & & & & & & & & & & \\
\hline & & hemorragia & & & $\mathrm{x}$ & & & $\mathrm{x}$ & & & $\mathrm{x}$ & $\mathrm{x}$ & & $\mathrm{x}$ \\
\hline & \multirow{5}{*}{$\begin{array}{l}\text { Infiltrado } \\
\text { inflamatório }\end{array}$} & neutrófilos & & & & & & & $\mathrm{x}$ & & & $\mathrm{x}$ & & \\
\hline & & macrófagos & & & & & & & & & & $\mathrm{x}$ & & $\mathrm{x}$ \\
\hline & & plasmócitos & & & & & & & & & & & & \\
\hline & & linfócitos & & & & & & & $\mathrm{x}$ & & $\mathrm{x}$ & $\mathrm{x}$ & & $\mathrm{x}$ \\
\hline & & CGMN & $\mathrm{x}$ & & & & & & & & & & & \\
\hline & \multicolumn{2}{|c|}{ Restos epiteliais de Malassez } & & & & & & & & & & & & \\
\hline \multirow{10}{*}{ 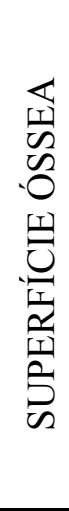 } & \multirow{4}{*}{$\begin{array}{c}\text { Face } \\
\text { periodontal }\end{array}$} & irregular c/ reabs & $\mathrm{x}$ & & $\mathrm{x}$ & & & & & & & & & \\
\hline & & irregular s/ reabs & & & & & & & $\mathrm{x}$ & & $\mathrm{x}$ & & & \\
\hline & & linha de reversão & $\mathrm{x}$ & & $\mathrm{x}$ & & & & & & $\mathrm{x}$ & & & \\
\hline & & osteóide & & & & & & & & & $\mathrm{x}$ & & & \\
\hline & \multirow{4}{*}{$\begin{array}{c}\text { Face } \\
\text { endosteal }\end{array}$} & irregular c/ reabs & & & & $\mathrm{x}$ & & $\mathrm{x}$ & & & & $\mathrm{x}$ & & $\mathrm{x}$ \\
\hline & & irregular s/ reabs & & & & & & & & & & & & \\
\hline & & linha de reversão & & & & & & & & & & & & \\
\hline & & osteóide & & & & & & & & & & & & \\
\hline & \multirow{2}{*}{ Crista óssea } & regular & & & & & & & & & & & & \\
\hline & & irregular & $\mathrm{x}$ & & $\mathrm{x}$ & $\mathrm{x}$ & & $\mathrm{x}$ & $\mathrm{x}$ & & $\mathrm{x}$ & $\mathrm{x}$ & & $\mathrm{x}$ \\
\hline \multirow{5}{*}{ 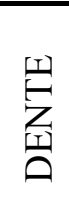 } & \multirow{4}{*}{$\begin{array}{l}\text { Superfície } \\
\text { cementária }\end{array}$} & regular & $\mathrm{x}$ & & & & & $\mathrm{x}$ & & & $\mathrm{x}$ & & & \\
\hline & & irregular s/ reabs & $\mathrm{x}$ & & & & & & & & & & & \\
\hline & & irregular c/ reabs & $\mathrm{x}$ & & & & & & & & & & & $\mathrm{x}$ \\
\hline & & Cementóide & & & & & & & $\mathrm{x}$ & & $\mathrm{x}$ & $\mathrm{x}$ & & \\
\hline & \multicolumn{2}{|c|}{ Reabsorção dentinária externa } & & & $\mathrm{x}$ & & & & & & & & & \\
\hline
\end{tabular}




\begin{tabular}{|c|c|c|c|c|c|c|c|c|c|c|c|c|c|c|}
\hline \multicolumn{3}{|c|}{$\begin{array}{ll}\text { Fenômenos } & \text { Espécimes } \\
\end{array}$} & $\begin{array}{c}1 \\
10\end{array}$ & $\begin{array}{c}2 \\
11\end{array}$ & $\begin{array}{c}3 \\
12\end{array}$ & $\begin{array}{c}1 \\
10\end{array}$ & $\begin{array}{c}2 \\
11\end{array}$ & $\begin{array}{c}3 \\
12\end{array}$ & $\begin{array}{c}1 \\
10\end{array}$ & $\begin{array}{c}2 \\
11\end{array}$ & $\begin{array}{c}3 \\
12\end{array}$ & $\begin{array}{c}1 \\
10\end{array}$ & $\begin{array}{c}2 \\
11\end{array}$ & $\begin{array}{c}3 \\
12\end{array}$ \\
\hline \multirow{5}{*}{ 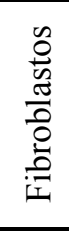 } & \multirow{3}{*}{ Núcleo } & mitótico & & & & & & & $\mathrm{x}$ & & & $\mathrm{x}$ & & \\
\hline & & picnótico & & & & & & $\mathrm{x}$ & & & & & & \\
\hline & & cariorrexe & & & & & & & & & & & & \\
\hline & \multirow{2}{*}{$\begin{array}{c}\text { Quanto à } \\
\text { disposição }\end{array}$} & fasciculado & $\mathrm{x}$ & & $\mathrm{x}$ & & & & $\mathrm{x}$ & & $\mathrm{x}$ & $\mathrm{x}$ & & $x$ \\
\hline & & ao acaso & $\mathrm{x}$ & & $\mathrm{x}$ & & & $\mathrm{x}$ & & & & & & $\mathrm{x}$ \\
\hline \multirow{7}{*}{$\begin{array}{l}\frac{n}{0} \\
\frac{\pi}{0} \\
\frac{\pi}{0} \\
0 \\
\frac{d}{0} \\
0\end{array}$} & \multirow{3}{*}{ Núcleo } & mitótico & & & & & & & & & & & & \\
\hline & & picnótico & & & & & & & & & & & & \\
\hline & & cariorrexe & & & & & & & & & & & & \\
\hline & \multirow{2}{*}{$\begin{array}{c}\text { Quanto à } \\
\text { disposição }\end{array}$} & fasciculado & & & & & & & & & & & & $\mathrm{x}$ \\
\hline & & ao acaso & $\mathrm{x}$ & & $x$ & & & & & & & & & $\mathrm{x}$ \\
\hline & \multirow{2}{*}{$\begin{array}{l}\text { Quanto à } \\
\text { superfície }\end{array}$} & justapostos & & & & & & $\mathrm{x}$ & & & $\mathrm{x}$ & & & $\mathrm{x}$ \\
\hline & & à distância & & & & & & & & & & & & $\mathrm{x}$ \\
\hline \multirow{6}{*}{$\begin{array}{l}0 \\
0 \\
\frac{0}{0} \\
\frac{\pi}{0} \\
0 \\
\frac{D}{n} \\
0\end{array}$} & \multirow{3}{*}{ Núcleo(s) } & mitótico & & & & & & & & & & & & \\
\hline & & picnótico & & & & & & & & & & & & \\
\hline & & cariorrexe & & & & & & & & & & & & \\
\hline & \multirow{3}{*}{$\begin{array}{c}\text { Quanto à } \\
\text { superfície }\end{array}$} & à distância & $\mathrm{x}$ & & & & & $\mathrm{x}$ & & & & & & $\mathrm{x}$ \\
\hline & & justapostos & & & $\mathrm{x}$ & & & $\mathrm{x}$ & & & & & & \\
\hline & & em lacunas & $\mathrm{x}$ & & & & & $\mathrm{x}$ & $\mathrm{x}$ & & & & & $\mathrm{x}$ \\
\hline \multirow{7}{*}{$\begin{array}{l}0 \\
0 \\
\frac{0}{0} \\
\frac{\pi}{0} \\
0 \\
\stackrel{0}{0} \\
\stackrel{0}{0}\end{array}$} & \multirow{3}{*}{ Núcleo } & mitótico & & & & & & & & & & & & \\
\hline & & picnótico & & & & & & & & & & & & \\
\hline & & cariorrexe & & & & & & & & & & & & \\
\hline & \multirow{2}{*}{$\begin{array}{c}\text { Quanto à } \\
\text { disposição }\end{array}$} & em paliçada & $\mathrm{x}$ & & & & & & & & & & & $\mathrm{x}$ \\
\hline & & ao acaso & & & $x$ & & & $\mathrm{x}$ & & & & & & \\
\hline & \multirow{2}{*}{$\begin{array}{c}\text { Quanto à } \\
\text { superfície }\end{array}$} & justapostos & $\mathrm{x}$ & & $\mathrm{x}$ & & & $\mathrm{x}$ & & & $\mathrm{x}$ & & & $\mathrm{x}$ \\
\hline & & à distância & & & & & & & & & & & & \\
\hline \multirow{6}{*}{ 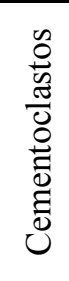 } & \multirow{3}{*}{ Núcleo(s) } & mitótico & & & & & & & & & & & & \\
\hline & & picnótico & & & & & & & & & & & & \\
\hline & & cariorrexe & & & & & & & & & & & & \\
\hline & \multirow{3}{*}{$\begin{array}{l}\text { Quanto à } \\
\text { superfície }\end{array}$} & à distância & & & & & & & & & & & & \\
\hline & & justapostos & & & & & & $\mathrm{x}$ & & & & & & \\
\hline & & em lacunas & & & & & & & & & & & & $\mathrm{x}$ \\
\hline
\end{tabular}

T - total; X - presença; c/ - com; s/ - sem; reabs - reabsorção; CGMN - células gigantes multinucleadas. 
Anexo 12 - Distribuição dos achados microscópicos referentes aos fenômenos morfologicamente detectados nos animais do Grupo E-5

\begin{tabular}{|c|c|c|c|c|c|c|c|c|c|c|c|c|c|c|}
\hline & \multicolumn{6}{|c|}{ ÁREA DE PRESSÃO } & \multicolumn{6}{|c|}{ ÁREA DE TENSÃO } \\
\hline & & & \multicolumn{3}{|c|}{ raiz mesial } & \multicolumn{3}{|c|}{ Raiz distal } & \multicolumn{3}{|c|}{ Raiz distal } & \multicolumn{3}{|c|}{ Raiz mesial } \\
\hline & & & 1 & 2 & 3 & 1 & 2 & 3 & 1 & 2 & 3 & 1 & 2 & 3 \\
\hline \multicolumn{3}{|c|}{ Fenômenos } & 13 & 14 & 15 & 13 & 14 & 15 & 13 & 14 & 15 & 13 & 14 & 15 \\
\hline \multirow{21}{*}{ 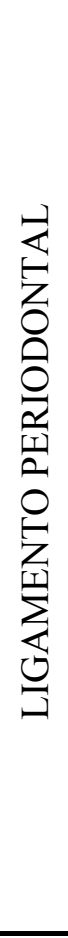 } & \multirow{2}{*}{ Largura } & aumentada & & & & & & & $\mathrm{x}$ & $\mathrm{x}$ & $\mathrm{x}$ & & $\mathrm{x}$ & $\mathrm{x}$ \\
\hline & & diminuída & $\mathrm{x}$ & $\mathrm{x}$ & $\mathrm{x}$ & $\mathrm{x}$ & $\mathrm{x}$ & $\mathrm{x}$ & & & & $\mathrm{x}$ & & \\
\hline & \multirow{2}{*}{$\begin{array}{l}\text { Fibras } \\
\text { colágenas }\end{array}$} & perpendiculares & & & & & & & $\mathrm{x}$ & & $\mathrm{x}$ & & $\mathrm{x}$ & $\mathrm{x}$ \\
\hline & & ao acaso & $\mathrm{x}$ & $\mathrm{x}$ & $\mathrm{x}$ & $\mathrm{x}$ & $\mathrm{x}$ & $\mathrm{x}$ & $\mathrm{x}$ & & & $\mathrm{x}$ & & \\
\hline & \multirow{3}{*}{$\begin{array}{l}\text { Áreas } \\
\text { hialinas }\end{array}$} & pequenas & $\mathrm{x}$ & & $\mathrm{x}$ & $\mathrm{x}$ & $\mathrm{x}$ & & $\mathrm{x}$ & & $\mathrm{x}$ & $\mathrm{x}$ & $\mathrm{x}$ & \\
\hline & & Médias & & $\mathrm{x}$ & & & $\mathrm{x}$ & & & & & & & $\mathrm{x}$ \\
\hline & & Grandes & & & & & & $\mathrm{x}$ & & & & & & \\
\hline & \multirow{4}{*}{$\begin{array}{c}\text { Vasos } \\
\text { sangüíneos }\end{array}$} & normais & & & & $\mathrm{x}$ & $\mathrm{x}$ & $\mathrm{x}$ & & & & $\mathrm{x}$ & $\mathrm{x}$ & $\mathrm{x}$ \\
\hline & & comprimidos & $\mathrm{x}$ & & $\mathrm{x}$ & $\mathrm{x}$ & & $\mathrm{x}$ & & & & $\mathrm{x}$ & & $\mathrm{x}$ \\
\hline & & colabados & & & $\mathrm{x}$ & & & & & & & & & \\
\hline & & dilatados & & & & & & & & & & $\mathrm{x}$ & $\mathrm{x}$ & \\
\hline & \multirow{4}{*}{$\begin{array}{l}\text { Alterações } \\
\text { circulatórias }\end{array}$} & congestão & $\mathrm{x}$ & $\mathrm{x}$ & & $\mathrm{x}$ & $\mathrm{x}$ & $\mathrm{x}$ & $\mathrm{x}$ & $\mathrm{x}$ & & $\mathrm{x}$ & $\mathrm{x}$ & $\mathrm{x}$ \\
\hline & & exsudato & & & & $\mathrm{x}$ & $\mathrm{x}$ & $\mathrm{x}$ & & & & $\mathrm{x}$ & & $\mathrm{x}$ \\
\hline & & trombose & & & & & & & & & & & & \\
\hline & & hemorragia & & $\mathrm{x}$ & $\mathrm{x}$ & & $\mathrm{x}$ & $\mathrm{x}$ & $x$ & $x$ & & $\mathrm{x}$ & $\mathrm{x}$ & $\mathrm{x}$ \\
\hline & \multirow{5}{*}{$\begin{array}{l}\text { Infiltrado } \\
\text { inflamatório }\end{array}$} & neutrófilos & & & & $\mathrm{x}$ & $\mathrm{x}$ & $\mathrm{x}$ & $\mathrm{x}$ & $\mathrm{x}$ & & $\mathrm{x}$ & $\mathrm{x}$ & $\mathrm{x}$ \\
\hline & & macrófagos & $\mathrm{x}$ & $\mathrm{x}$ & $\mathrm{x}$ & $\mathrm{x}$ & $\mathrm{x}$ & $\mathrm{x}$ & & & & & $\mathrm{x}$ & $\mathrm{x}$ \\
\hline & & plasmócitos & & & & & & & & & & & & \\
\hline & & linfócitos & & & $\mathrm{x}$ & $\mathrm{x}$ & $\mathrm{x}$ & $\mathrm{x}$ & $\mathrm{x}$ & $\mathrm{x}$ & & & $\mathrm{x}$ & $\mathrm{x}$ \\
\hline & & CGMN & $\mathrm{x}$ & $\mathrm{x}$ & $\mathrm{x}$ & $\mathrm{x}$ & $\mathrm{x}$ & $\mathrm{x}$ & & & & $\mathrm{x}$ & & $\mathrm{x}$ \\
\hline & \multicolumn{2}{|c|}{ Restos epiteliais de Malassez } & & & & & & & & & & & & \\
\hline \multirow{10}{*}{ 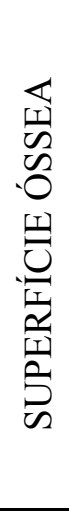 } & \multirow{4}{*}{$\begin{array}{c}\text { Face } \\
\text { periodontal }\end{array}$} & irregular c/ reabs & $\mathrm{x}$ & $\mathrm{x}$ & & & & & & & & & & \\
\hline & & irregular s/ reabs & & & & & & & & $\mathrm{x}$ & & & & \\
\hline & & linha de reversão & & & & & & & & & & & & \\
\hline & & osteóide & & & & & & & & & & & & \\
\hline & \multirow{4}{*}{$\begin{array}{c}\text { Face } \\
\text { endosteal }\end{array}$} & irregular c/ reabs & & $\mathrm{x}$ & & & $\mathrm{x}$ & $\mathrm{x}$ & $\mathrm{x}$ & $\mathrm{x}$ & & $\mathrm{x}$ & & \\
\hline & & irregular s/ reabs & & & & $\mathrm{x}$ & & & & & & $\mathrm{x}$ & $\mathrm{x}$ & $\mathrm{x}$ \\
\hline & & linha de reversão & & & & & & & & & & & & \\
\hline & & osteóide & & & & & & & & & & & & \\
\hline & \multirow{2}{*}{ Crista óssea } & regular & & & & & & & & & & & $\mathrm{x}$ & \\
\hline & & irregular & $\mathrm{x}$ & $\mathrm{x}$ & $\mathrm{x}$ & $\mathrm{x}$ & $\mathrm{x}$ & $\mathrm{x}$ & & & & $\mathrm{x}$ & & $\mathrm{x}$ \\
\hline \multirow{5}{*}{ 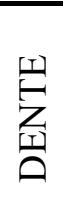 } & \multirow{4}{*}{$\begin{array}{l}\text { Superfície } \\
\text { cementária }\end{array}$} & regular & $\mathrm{x}$ & & & & $\mathrm{x}$ & $\mathrm{x}$ & & & & $\mathrm{x}$ & $\mathrm{x}$ & $\mathrm{x}$ \\
\hline & & irregular s/ reabs & & $\mathrm{x}$ & & & & & & & & & & \\
\hline & & irregular c/ reabs & & & & $\mathrm{x}$ & & & $\mathrm{x}$ & & & & & \\
\hline & & Cementóide & & & & $\mathrm{x}$ & & & & & & & $\mathrm{x}$ & $\mathrm{x}$ \\
\hline & Reabsorção & ntinária externa & & & & $\mathrm{x}$ & & & & & & & & \\
\hline
\end{tabular}




\begin{tabular}{|c|c|c|c|c|c|c|c|c|c|c|c|c|c|c|}
\hline \multirow{2}{*}{\multicolumn{3}{|c|}{\begin{tabular}{|ll} 
& Espécimes
\end{tabular}}} & 1 & 2 & 3 & 1 & 2 & 3 & 1 & 2 & 3 & 1 & 2 & 3 \\
\hline \multicolumn{2}{|c|}{ Fenômenos } & & 13 & 14 & 15 & 13 & 14 & 15 & 13 & 14 & 15 & 13 & 14 & 15 \\
\hline \multirow{5}{*}{ 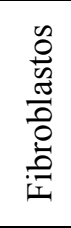 } & \multirow{3}{*}{ Núcleo } & mitótico & & & & $\mathrm{x}$ & & & $\mathrm{x}$ & & & & & $\mathrm{x}$ \\
\hline & & picnótico & & & & $\mathrm{x}$ & $\mathrm{x}$ & & & & & & & \\
\hline & & cariorrexe & & & & $\mathrm{x}$ & $\mathrm{x}$ & $\mathrm{x}$ & & & & & $\mathrm{x}$ & $\mathrm{x}$ \\
\hline & \multirow{2}{*}{$\begin{array}{c}\text { Quanto à } \\
\text { disposição }\end{array}$} & fasciculado & & & & & & & & $\mathrm{x}$ & & $\mathrm{x}$ & $\mathrm{x}$ & $\mathrm{x}$ \\
\hline & & ao acaso & $\mathrm{x}$ & $\mathrm{x}$ & & $\mathrm{x}$ & $\mathrm{x}$ & $\mathrm{x}$ & & & & & & \\
\hline \multirow{7}{*}{$\begin{array}{l}\frac{n}{0} \\
\frac{\pi}{0} \\
\frac{\pi}{0} \\
0 \\
\frac{d}{0} \\
0\end{array}$} & \multirow{3}{*}{ Núcleo } & mitótico & & & & & & & $\bar{x}$ & & & & & \\
\hline & & picnótico & & & & & & & & & & & & \\
\hline & & cariorrexe & & & & & & & & & & & & \\
\hline & \multirow{2}{*}{$\begin{array}{c}\text { Quanto à } \\
\text { disposição }\end{array}$} & fasciculado & & & & & $\mathrm{x}$ & & & & & $\mathrm{x}$ & $\mathrm{x}$ & $\mathrm{x}$ \\
\hline & & ao acaso & & & & & & & $\mathrm{x}$ & & $\mathrm{x}$ & & & \\
\hline & \multirow{2}{*}{$\begin{array}{l}\text { Quanto à } \\
\text { superfície }\end{array}$} & justapostos & $\mathrm{x}$ & & & $\mathrm{x}$ & & & $\mathrm{x}$ & & & $x$ & $\mathrm{x}$ & $\mathrm{x}$ \\
\hline & & à distância & & & & $\mathrm{x}$ & & & & & & & & \\
\hline \multirow{6}{*}{$\begin{array}{l}0 \\
0 \\
\frac{0}{0} \\
\frac{\pi}{0} \\
0 \\
\frac{D}{n} \\
0\end{array}$} & \multirow{3}{*}{ Núcleo(s) } & mitótico & & & & & & & & & & & & \\
\hline & & picnótico & & & & & & & & & & & & \\
\hline & & cariorrexe & & & & & & & & & & & & \\
\hline & \multirow{3}{*}{$\begin{array}{c}\text { Quanto à } \\
\text { superfície }\end{array}$} & à distância & & & & $\mathrm{x}$ & $\mathrm{x}$ & $\mathrm{x}$ & & & & $\mathrm{x}$ & & $\mathrm{x}$ \\
\hline & & justapostos & & & & $\mathrm{x}$ & $\mathrm{x}$ & $\mathrm{x}$ & & & & & & $\mathrm{x}$ \\
\hline & & em lacunas & $\mathrm{x}$ & & $\mathrm{x}$ & $\mathrm{x}$ & $\mathrm{x}$ & $x$ & $\mathrm{x}$ & & & $\mathrm{x}$ & & $\mathrm{x}$ \\
\hline \multirow{7}{*}{ 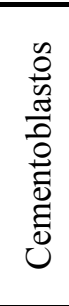 } & \multirow{3}{*}{ Núcleo } & mitótico & & & & & & $\mathrm{x}$ & & & & & & \\
\hline & & picnótico & & & & $\mathrm{x}$ & & & & & & & & \\
\hline & & cariorrexe & & & & & & & & & & & & \\
\hline & \multirow{2}{*}{$\begin{array}{c}\text { Quanto à } \\
\text { disposição }\end{array}$} & em paliçada & & & $\mathrm{x}$ & $\mathrm{x}$ & & & $\mathrm{x}$ & $\mathrm{x}$ & & $\mathrm{x}$ & $\mathrm{x}$ & $\mathrm{x}$ \\
\hline & & ao acaso & $\mathrm{x}$ & & & & & $\mathrm{x}$ & & & & & & \\
\hline & \multirow{2}{*}{$\begin{array}{c}\text { Quanto à } \\
\text { superfície }\end{array}$} & justapostos & & & $\mathrm{x}$ & $\mathrm{x}$ & $\mathrm{x}$ & $\mathrm{x}$ & $\mathrm{x}$ & & & $\mathrm{x}$ & $\mathrm{x}$ & $\mathrm{x}$ \\
\hline & & à distância & & & $\mathrm{x}$ & & & & & & & & & \\
\hline \multirow{6}{*}{ 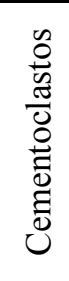 } & \multirow{3}{*}{ Núcleo(s) } & mitótico & & & & & & & & & & & & \\
\hline & & picnótico & & & & & & & & & & & & \\
\hline & & cariorrexe & & & & & & & & & & & & \\
\hline & \multirow{3}{*}{$\begin{array}{l}\text { Quanto à } \\
\text { superfície }\end{array}$} & à distância & & & & $\mathrm{x}$ & & & & & & & & \\
\hline & & justapostos & & & & & & & & & & & & \\
\hline & & em lacunas & $\mathrm{x}$ & $\mathrm{x}$ & $\mathrm{x}$ & $\mathrm{x}$ & & & $\mathrm{x}$ & & & & & \\
\hline
\end{tabular}

T - total; X - presença; c/ - com; s/ - sem; reabs - reabsorção; CGMN - células gigantes multinucleadas. 
Anexo 13 - Distribuição dos achados microscópicos referentes aos fenômenos morfologicamente detectados nos animais do Grupo E-6

\begin{tabular}{|c|c|c|c|c|c|c|c|c|c|c|c|c|c|c|}
\hline & \multicolumn{6}{|c|}{ ÁREA DE PRESSÃO } & \multicolumn{6}{|c|}{ ÁREA DE TENSÃO } \\
\hline & & & \multicolumn{3}{|c|}{ raiz mesial } & \multicolumn{3}{|c|}{ Raiz distal } & \multicolumn{3}{|c|}{ Raiz distal } & \multicolumn{3}{|c|}{ Raiz mesial } \\
\hline & & & 1 & 2 & 3 & 1 & 2 & 3 & 1 & 2 & 3 & 1 & 2 & 3 \\
\hline \multicolumn{3}{|c|}{ Fenômenos } & 16 & 17 & 18 & 16 & 17 & 18 & 16 & 17 & 18 & 16 & 17 & 18 \\
\hline \multirow{21}{*}{ 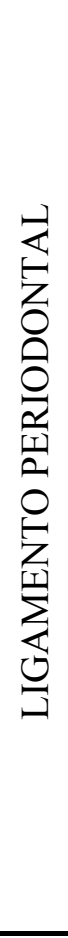 } & \multirow{2}{*}{ Largura } & aumentada & & & & & & & $\mathrm{x}$ & $\mathrm{x}$ & & $\mathrm{x}$ & $\mathrm{x}$ & \\
\hline & & diminuída & $\mathrm{x}$ & $\mathrm{x}$ & & $\mathrm{x}$ & $\mathrm{x}$ & $\mathrm{x}$ & & & & & & \\
\hline & \multirow{2}{*}{$\begin{array}{l}\text { Fibras } \\
\text { colágenas }\end{array}$} & perpendiculares & $\mathrm{x}$ & $\mathrm{x}$ & & & & $\mathrm{x}$ & $\mathrm{x}$ & $\mathrm{x}$ & & $\mathrm{x}$ & $\mathrm{x}$ & \\
\hline & & ao acaso & $\mathrm{x}$ & $\mathrm{x}$ & & $\mathrm{x}$ & $\mathrm{x}$ & $\mathrm{x}$ & & & & & & \\
\hline & \multirow{3}{*}{$\begin{array}{c}\text { Áreas } \\
\text { hialinas }\end{array}$} & pequenas & $\mathrm{x}$ & $\mathrm{x}$ & & & & & $\mathrm{x}$ & $\mathrm{x}$ & & $\mathrm{x}$ & $\mathrm{x}$ & \\
\hline & & Médias & & & & & & $\mathrm{x}$ & & & & & & \\
\hline & & Grandes & & & & $\mathrm{x}$ & $\mathrm{x}$ & & & & & & & \\
\hline & \multirow{4}{*}{$\begin{array}{c}\text { Vasos } \\
\text { sangüíneos }\end{array}$} & normais & & $\mathrm{x}$ & & & & & $\mathrm{x}$ & $\mathrm{x}$ & & $\mathrm{x}$ & $\mathrm{x}$ & \\
\hline & & comprimidos & $\mathrm{x}$ & $\mathrm{x}$ & & $\mathrm{x}$ & $\mathrm{x}$ & & & $\mathrm{x}$ & & & & \\
\hline & & colabados & $\mathrm{x}$ & & & $\mathrm{x}$ & & & & & & & & \\
\hline & & dilatados & & & & & & & $\mathrm{x}$ & & & & $\mathrm{x}$ & \\
\hline & \multirow{4}{*}{$\begin{array}{l}\text { Alterações } \\
\text { circulatórias }\end{array}$} & congestão & $\mathrm{x}$ & $\mathrm{x}$ & & $\mathrm{x}$ & $\mathrm{x}$ & & $\mathrm{x}$ & $\mathrm{x}$ & & $\mathrm{x}$ & $\mathrm{x}$ & \\
\hline & & exsudato & & $\mathrm{x}$ & & & & & & & & & & \\
\hline & & trombose & & & & & & & & & & & & \\
\hline & & hemorragia & $\mathrm{x}$ & $\mathrm{x}$ & & $\mathrm{x}$ & $\mathrm{x}$ & & $x$ & & & $\mathrm{x}$ & $\mathrm{x}$ & \\
\hline & \multirow{5}{*}{$\begin{array}{l}\text { Infiltrado } \\
\text { inflamatório }\end{array}$} & neutrófilos & $\mathrm{x}$ & $\mathrm{x}$ & & & & & $\mathrm{x}$ & $\mathrm{x}$ & & & $\mathrm{x}$ & \\
\hline & & macrófagos & $\mathrm{x}$ & $\mathrm{x}$ & & $\mathrm{x}$ & & & $\mathrm{x}$ & & & $\mathrm{x}$ & & \\
\hline & & plasmócitos & & & & & & & & & & & & \\
\hline & & linfócitos & $\mathrm{x}$ & $\mathrm{x}$ & & $\mathrm{x}$ & $\mathrm{x}$ & & $\mathrm{x}$ & $\mathrm{x}$ & & $\mathrm{x}$ & & \\
\hline & & CGMN & $\mathrm{x}$ & & & $\mathrm{x}$ & & & & & & & & \\
\hline & \multicolumn{2}{|c|}{ Restos epiteliais de Malassez } & & & & & & & & & & & & \\
\hline \multirow{10}{*}{ 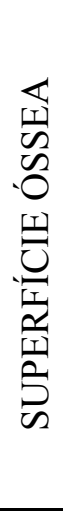 } & \multirow{4}{*}{$\begin{array}{c}\text { Face } \\
\text { periodontal }\end{array}$} & irregular c/ reabs & $\mathrm{x}$ & $\mathrm{x}$ & & & & & $\mathrm{x}$ & $\mathrm{x}$ & & & & \\
\hline & & irregular s/ reabs & & & & & & & $\mathrm{x}$ & & & & & \\
\hline & & linha de reversão & & & & & & & $\mathrm{x}$ & $\mathrm{x}$ & & & & \\
\hline & & osteóide & & & & & & & $\mathrm{x}$ & & & & & \\
\hline & \multirow{4}{*}{$\begin{array}{c}\text { Face } \\
\text { endosteal }\end{array}$} & irregular c/ reabs & & & & $\mathrm{x}$ & $\mathrm{x}$ & & & & & $\mathrm{x}$ & $\mathrm{x}$ & \\
\hline & & irregular s/ reabs & & & & & & & & & & $\mathrm{x}$ & $\mathrm{x}$ & \\
\hline & & linha de reversão & & & & & & & & & & & & \\
\hline & & osteóide & & & & & & & & & & & & \\
\hline & \multirow{2}{*}{ Crista óssea } & regular & & & & & & & & & & & $\mathrm{x}$ & \\
\hline & & irregular & $\mathrm{x}$ & $\mathrm{x}$ & & $\mathrm{x}$ & $\mathrm{x}$ & & $\mathrm{x}$ & $\mathrm{x}$ & & $\mathrm{x}$ & & \\
\hline \multirow{5}{*}{ 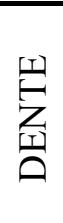 } & \multirow{4}{*}{$\begin{array}{l}\text { Superfície } \\
\text { cementária }\end{array}$} & regular & & & & & & & $x$ & $\mathrm{x}$ & & $\mathrm{x}$ & & \\
\hline & & irregular s/ reabs & $\mathrm{x}$ & & & & & & & & & & & \\
\hline & & irregular c/ reabs & $\mathrm{x}$ & & & $\mathrm{x}$ & & & & & & & & \\
\hline & & Cementóide & & & & & & & & & & $\mathrm{x}$ & $\mathrm{x}$ & \\
\hline & Reabsorção & ntinária externa & & & & & & & & & & & & \\
\hline
\end{tabular}




\begin{tabular}{|c|c|c|c|c|c|c|c|c|c|c|c|c|c|c|}
\hline \multicolumn{3}{|c|}{ Fenômenos $\quad$ Espécimes } & $\begin{array}{c}1 \\
16\end{array}$ & $\begin{array}{c}2 \\
17 \\
\end{array}$ & $\begin{array}{c}3 \\
18 \\
\end{array}$ & $\begin{array}{c}1 \\
16 \\
\end{array}$ & $\begin{array}{c}2 \\
17 \\
\end{array}$ & $\begin{array}{c}3 \\
18\end{array}$ & $\begin{array}{c}1 \\
16 \\
\end{array}$ & $\begin{array}{c}2 \\
17 \\
\end{array}$ & $\begin{array}{c}3 \\
18 \\
\end{array}$ & $\begin{array}{c}1 \\
16 \\
\end{array}$ & $\begin{array}{c}2 \\
17 \\
\end{array}$ & $\begin{array}{c}3 \\
18 \\
\end{array}$ \\
\hline \multirow{5}{*}{$\begin{array}{l}0 \\
0 \\
0 \\
\frac{0}{0} \\
0 \\
0 \\
0 \\
0 \\
0\end{array}$} & \multirow{3}{*}{ Núcleo } & mitótico & & & & $\mathrm{x}$ & & & & & & $\mathrm{x}$ & & \\
\hline & & picnótico & $\mathrm{x}$ & $\mathrm{x}$ & & $\mathrm{x}$ & $\mathrm{x}$ & & & & & & & \\
\hline & & cariorrexe & & & & & & & & & & & & \\
\hline & \multirow{2}{*}{$\begin{array}{c}\text { Quanto à } \\
\text { disposição }\end{array}$} & fasciculado & $\mathrm{x}$ & $\mathrm{x}$ & & $\mathrm{x}$ & $\mathrm{x}$ & & $\mathrm{x}$ & $\mathrm{x}$ & & $\mathrm{x}$ & $\mathrm{x}$ & \\
\hline & & ao acaso & $\mathrm{x}$ & $\mathrm{x}$ & & $\mathrm{x}$ & $\mathrm{x}$ & & & & & & & \\
\hline \multirow{7}{*}{ 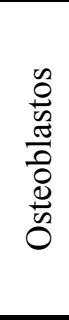 } & \multirow{3}{*}{ Núcleo } & mitótico & & & & & & & & & & & & \\
\hline & & picnótico & & & & & & & & & & & & \\
\hline & & cariorrexe & & & & & & & & & & & & \\
\hline & \multirow{2}{*}{$\begin{array}{c}\text { Quanto à } \\
\text { disposição }\end{array}$} & fasciculado & & & & & & & $\mathrm{x}$ & & & $\mathrm{x}$ & & \\
\hline & & ao acaso & & $\mathrm{x}$ & & & $\mathrm{x}$ & $\mathrm{x}$ & & $\mathrm{x}$ & & & & \\
\hline & \multirow{2}{*}{$\begin{array}{l}\text { Quanto à } \\
\text { superfície }\end{array}$} & justapostos & & & & & & & $\mathrm{x}$ & & & $\mathrm{x}$ & & \\
\hline & & à distância & & $\mathrm{x}$ & & & $x$ & & & & & & & \\
\hline \multirow{6}{*}{ 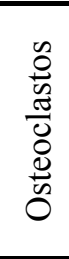 } & \multirow{3}{*}{ Núcleo(s) } & mitótico & & & & & & & & & & & & \\
\hline & & picnótico & & & & & & & & & & & & \\
\hline & & cariorrexe & & & & & & & & & & & & \\
\hline & \multirow{3}{*}{$\begin{array}{l}\text { Quanto à } \\
\text { superfície }\end{array}$} & à distância & $\mathrm{x}$ & & & $\mathrm{x}$ & $\mathrm{x}$ & & $x$ & $\mathrm{x}$ & & $\mathrm{x}$ & & \\
\hline & & justapostos & & & & & & & & & & & & \\
\hline & & em lacunas & $\mathrm{x}$ & $\mathrm{x}$ & & $\mathrm{x}$ & $\mathrm{x}$ & & $\mathrm{x}$ & & & & & \\
\hline \multirow{7}{*}{ 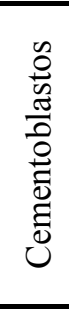 } & \multirow{3}{*}{ Núcleo } & mitótico & & & & & & & & & & & & \\
\hline & & picnótico & & & & & & & & & & & & \\
\hline & & cariorrexe & & & & & & & & & & & & \\
\hline & \multirow{2}{*}{$\begin{array}{c}\text { Quanto à } \\
\text { disposição }\end{array}$} & em paliçada & & $\mathrm{x}$ & & & & & $x$ & & & $\mathrm{x}$ & & \\
\hline & & ao acaso & & & & & & & & & & & & \\
\hline & \multirow{2}{*}{$\begin{array}{c}\text { Quanto à } \\
\text { superfície }\end{array}$} & justapostos & $\mathrm{x}$ & $\mathrm{x}$ & & & $\mathrm{x}$ & & $x$ & $\mathrm{x}$ & & $\mathrm{x}$ & $x$ & \\
\hline & & à distância & & & & & & & & & & & & \\
\hline \multirow{6}{*}{ 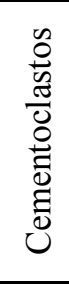 } & \multirow{3}{*}{ Núcleo(s) } & mitótico & & & & & & & & & & & & \\
\hline & & picnótico & & & & & & & & & & & & \\
\hline & & cariorrexe & & & & & & & & & & & & \\
\hline & \multirow{3}{*}{$\begin{array}{l}\text { Quanto à } \\
\text { superfície }\end{array}$} & à distância & & & & & & & & & & & & \\
\hline & & justapostos & & & & & $\mathrm{x}$ & & & & & & & \\
\hline & & em lacunas & $\mathrm{x}$ & & & $\mathrm{x}$ & & & & & & & & \\
\hline
\end{tabular}

T - total; X - presença; c/ - com; s/ - sem; reabs - reabsorção; CGMN - células gigantes multinucleadas. 
Anexo 14 - Distribuição dos achados microscópicos referentes aos fenômenos morfologicamente detectados nos animais do Grupo E-7

\begin{tabular}{|c|c|c|c|c|c|c|c|c|c|c|c|c|c|c|}
\hline \multirow{3}{*}{\multicolumn{3}{|c|}{ Espécimes }} & \multicolumn{6}{|c|}{ ÁREA DE PRESSÃO } & \multicolumn{6}{|c|}{ ÁREA DE TENSÃO } \\
\hline & & & \multicolumn{3}{|c|}{ raiz mesial } & \multicolumn{3}{|c|}{ Raiz distal } & \multicolumn{3}{|c|}{ Raiz distal } & \multicolumn{3}{|c|}{ Raiz mesial } \\
\hline & & & $\begin{array}{c}1 \\
19\end{array}$ & $\begin{array}{c}2 \\
20\end{array}$ & $\begin{array}{c}3 \\
21\end{array}$ & $\begin{array}{c}1 \\
19\end{array}$ & $\begin{array}{c}2 \\
20\end{array}$ & $\begin{array}{c}3 \\
21\end{array}$ & $\begin{array}{c}1 \\
19\end{array}$ & $\begin{array}{c}2 \\
20\end{array}$ & $\begin{array}{c}3 \\
21\end{array}$ & $\begin{array}{c}1 \\
19\end{array}$ & $\begin{array}{c}2 \\
20\end{array}$ & 3 \\
\hline \multirow{21}{*}{ 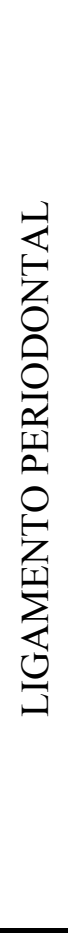 } & \multirow{2}{*}{ Largura } & aumentada & & & & & & & $\mathrm{x}$ & & & $\mathrm{x}$ & & $\mathrm{x}$ \\
\hline & & diminuída & $\mathrm{x}$ & & $\mathrm{x}$ & & & $\mathrm{x}$ & & & $\mathrm{x}$ & & & \\
\hline & \multirow{2}{*}{$\begin{array}{l}\text { Fibras } \\
\text { colágenas }\end{array}$} & perpendiculares & & & & & & & $\mathrm{x}$ & & $\mathrm{x}$ & $\mathrm{x}$ & & $\mathrm{x}$ \\
\hline & & ao acaso & $\mathrm{x}$ & & $\mathrm{x}$ & & & $\mathrm{x}$ & & & & & & \\
\hline & \multirow{3}{*}{$\begin{array}{l}\text { Áreas } \\
\text { hialinas }\end{array}$} & pequenas & $\mathrm{x}$ & & $\mathrm{x}$ & & & $\mathrm{x}$ & & & & $\mathrm{x}$ & & \\
\hline & & Médias & & & & & & & & & & & & \\
\hline & & Grandes & & & & & & & & & & & & \\
\hline & \multirow{4}{*}{$\begin{array}{c}\text { Vasos } \\
\text { sangüíneos }\end{array}$} & normais & & & & $\mathrm{x}$ & & & & & $\mathrm{x}$ & $\mathrm{x}$ & & \\
\hline & & comprimidos & $\mathrm{x}$ & & $\mathrm{x}$ & $\mathrm{x}$ & & $\mathrm{x}$ & $\mathrm{x}$ & & & $\mathrm{x}$ & & \\
\hline & & colabados & & & & & & & & & & & & \\
\hline & & dilatados & & & & & & & & & & & & $\mathrm{x}$ \\
\hline & \multirow{4}{*}{$\begin{array}{l}\text { Alterações } \\
\text { circulatórias }\end{array}$} & congestão & $\mathrm{x}$ & & $\mathrm{x}$ & $\mathrm{x}$ & & $\mathrm{x}$ & $\mathrm{x}$ & & $\mathrm{x}$ & $\mathrm{x}$ & & $\mathrm{x}$ \\
\hline & & exsudato & & & & $\mathrm{x}$ & & $\mathrm{x}$ & & & & & & $\mathrm{x}$ \\
\hline & & trombose & & & & & & & & & & & & \\
\hline & & hemorragia & $\mathrm{x}$ & & $\mathrm{x}$ & $\mathrm{x}$ & & $\mathrm{x}$ & $x$ & & $\mathrm{x}$ & $\mathrm{x}$ & & $\mathrm{x}$ \\
\hline & \multirow{5}{*}{$\begin{array}{l}\text { Infiltrado } \\
\text { inflamatório }\end{array}$} & neutrófilos & & & & $\mathrm{x}$ & & & & & $\mathrm{x}$ & & & \\
\hline & & macrófagos & $\mathrm{x}$ & & $\mathrm{x}$ & & & $\mathrm{x}$ & $x$ & & & $\mathrm{x}$ & & \\
\hline & & plasmócitos & & & & & & & & & & & & \\
\hline & & linfócitos & $\mathrm{x}$ & & & & & $\mathrm{x}$ & & & $\mathrm{x}$ & & & $\mathrm{x}$ \\
\hline & & CGMN & & & $\mathrm{x}$ & & & $\mathrm{x}$ & & & $\mathrm{x}$ & & & $\mathrm{x}$ \\
\hline & \multicolumn{2}{|c|}{ Restos epiteliais de Malassez } & & & & & & & & & & & & \\
\hline \multirow{10}{*}{ 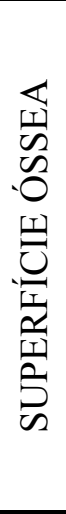 } & \multirow{4}{*}{$\begin{array}{c}\text { Face } \\
\text { periodontal }\end{array}$} & irregular c/ reabs & $\mathrm{x}$ & & $\mathrm{x}$ & & & & & & & & & \\
\hline & & irregular s/ reabs & & & & & & & $\mathrm{x}$ & & & & & \\
\hline & & linha de reversão & & & & & & & & & & & & \\
\hline & & osteóide & & & & & & & & & & & & \\
\hline & \multirow{4}{*}{$\begin{array}{c}\text { Face } \\
\text { endosteal }\end{array}$} & irregular c/ reabs & & & & $\mathrm{x}$ & & $x$ & $\mathrm{x}$ & & & $\mathrm{x}$ & & $\mathrm{x}$ \\
\hline & & irregular s/ reabs & & & & & & & & & & $\mathrm{x}$ & & $\mathrm{x}$ \\
\hline & & linha de reversão & & & & & & & & & & & & \\
\hline & & osteóide & & & & & & & $x$ & & $\mathrm{x}$ & & & \\
\hline & \multirow{2}{*}{ Crista óssea } & regular & & & & & & & & & & $\mathrm{x}$ & & \\
\hline & & irregular & $\mathrm{x}$ & & $\mathrm{x}$ & $\mathrm{x}$ & & $\mathrm{x}$ & & & $\mathrm{x}$ & & & \\
\hline \multirow{5}{*}{ 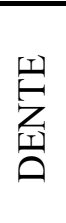 } & \multirow{4}{*}{$\begin{array}{l}\text { Superfície } \\
\text { cementária }\end{array}$} & regular & & & & & & $\mathrm{x}$ & & & & $\mathrm{x}$ & & $\bar{x}$ \\
\hline & & irregular s/ reabs & & & & $\mathrm{x}$ & & & & & & & & \\
\hline & & irregular c/ reabs & $\mathrm{x}$ & & & & & & & & & & & \\
\hline & & Cementóide & & & & & & & & & $\mathrm{x}$ & $\mathrm{x}$ & & $\mathrm{x}$ \\
\hline & \multicolumn{2}{|c|}{ Reabsorção dentinária externa } & & & & & & & & & & & & \\
\hline
\end{tabular}




\begin{tabular}{|c|c|c|c|c|c|c|c|c|c|c|c|c|c|c|}
\hline \multicolumn{3}{|c|}{$\begin{array}{ll}\text { Fenômenos } & \text { Espécimes } \\
\end{array}$} & $\begin{array}{c}1 \\
19\end{array}$ & $\begin{array}{c}2 \\
20\end{array}$ & $\begin{array}{c}3 \\
21\end{array}$ & $\begin{array}{c}1 \\
19\end{array}$ & $\begin{array}{c}2 \\
20\end{array}$ & $\begin{array}{c}3 \\
21\end{array}$ & $\begin{array}{c}1 \\
19\end{array}$ & $\begin{array}{c}2 \\
20\end{array}$ & $\begin{array}{c}3 \\
21\end{array}$ & $\begin{array}{c}1 \\
19\end{array}$ & $\begin{array}{c}2 \\
20\end{array}$ & $\begin{array}{c}3 \\
21\end{array}$ \\
\hline \multirow{5}{*}{ 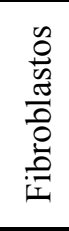 } & \multirow{3}{*}{ Núcleo } & mitótico & & & & & & & & & & & & \\
\hline & & picnótico & & & & $\mathrm{x}$ & & $\mathrm{x}$ & & & & & & $\mathrm{x}$ \\
\hline & & cariorrexe & & & & & & & & & & $\mathrm{x}$ & & \\
\hline & \multirow{2}{*}{$\begin{array}{c}\text { Quanto à } \\
\text { disposição }\end{array}$} & fasciculado & & & & & & & $\mathrm{x}$ & & $\mathrm{x}$ & $\mathrm{x}$ & & $x$ \\
\hline & & ao acaso & $\mathrm{x}$ & & $\mathrm{x}$ & $\mathrm{x}$ & & $x$ & & & & & & \\
\hline \multirow{7}{*}{$\begin{array}{l}\frac{n}{0} \\
\frac{\pi}{0} \\
\frac{\pi}{0} \\
0 \\
\frac{d}{0} \\
0\end{array}$} & \multirow{3}{*}{ Núcleo } & mitótico & & & & & & & & & $\mathrm{x}$ & & & \\
\hline & & picnótico & & & & & & & & & & & & \\
\hline & & cariorrexe & & & & & & & & & & & & \\
\hline & \multirow{2}{*}{$\begin{array}{c}\text { Quanto à } \\
\text { disposição }\end{array}$} & fasciculado & & & & & & $\mathrm{x}$ & & & $\mathrm{x}$ & $\mathrm{x}$ & & \\
\hline & & ao acaso & $\mathrm{x}$ & & $\mathrm{x}$ & $\mathrm{x}$ & & & $x$ & & $\mathrm{x}$ & & & $x$ \\
\hline & \multirow{2}{*}{$\begin{array}{l}\text { Quanto à } \\
\text { superfície }\end{array}$} & justapostos & & & & & & $x$ & $x$ & & $\mathrm{x}$ & $\mathrm{x}$ & & \\
\hline & & à distância & & & & & & & & & & & & \\
\hline \multirow{6}{*}{$\begin{array}{l}0 \\
0 \\
\frac{0}{0} \\
\frac{\pi}{0} \\
0 \\
\frac{D}{n} \\
0\end{array}$} & \multirow{3}{*}{ Núcleo(s) } & mitótico & & & & & & & & & & & & \\
\hline & & picnótico & & & & & & & & & & & & \\
\hline & & cariorrexe & & & & & & & & & & & & \\
\hline & \multirow{3}{*}{$\begin{array}{c}\text { Quanto à } \\
\text { superfície }\end{array}$} & à distância & & & $\mathrm{x}$ & $\mathrm{x}$ & & $\mathrm{x}$ & & & & & & $x$ \\
\hline & & justapostos & & & & & & $\mathrm{x}$ & & & & & & \\
\hline & & em lacunas & $\mathrm{x}$ & & $\mathrm{x}$ & $\mathrm{x}$ & & $x$ & $\mathrm{x}$ & & & $\mathrm{x}$ & & $\mathrm{x}$ \\
\hline \multirow{7}{*}{$\begin{array}{l}0 \\
0 \\
\frac{0}{0} \\
\frac{\pi}{0} \\
0 \\
\stackrel{0}{0} \\
\stackrel{0}{0}\end{array}$} & \multirow{3}{*}{ Núcleo } & mitótico & & & & & & & & & & & & \\
\hline & & picnótico & & & & & & & & & & & & \\
\hline & & cariorrexe & & & & & & & & & & & & \\
\hline & \multirow{2}{*}{$\begin{array}{c}\text { Quanto à } \\
\text { disposição }\end{array}$} & em paliçada & & & & & & & & & $x$ & $\mathrm{x}$ & & $\mathrm{x}$ \\
\hline & & ao acaso & & & & $\mathrm{x}$ & & & & & & & & \\
\hline & \multirow{2}{*}{$\begin{array}{l}\text { Quanto à } \\
\text { superfície }\end{array}$} & justapostos & $\mathrm{x}$ & & & & & $\mathrm{x}$ & $\mathrm{x}$ & & $\mathrm{x}$ & $\mathrm{x}$ & & $\mathrm{x}$ \\
\hline & & à distância & & & & & & & & & & & & \\
\hline \multirow{6}{*}{ 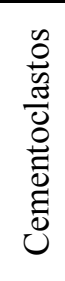 } & \multirow{3}{*}{ Núcleo(s) } & mitótico & & & & & & & & & & & & \\
\hline & & picnótico & & & & & & & & & & & & \\
\hline & & cariorrexe & & & & & & & & & & & & \\
\hline & \multirow{3}{*}{$\begin{array}{l}\text { Quanto à } \\
\text { superfície }\end{array}$} & à distância & & & & & & & & & & & & \\
\hline & & justapostos & & & & & & & & & & & & \\
\hline & & em lacunas & $\mathrm{x}$ & & $\mathrm{x}$ & & & & & & & & & \\
\hline
\end{tabular}

T - total; X - presença; c/ - com; s/ - sem; reabs - reabsorção; CGMN - células gigantes multinucleadas. 
APÊNDICE 
Protocolo de Pesquisa

Comprovante de Entrega - Comitè de Ética

Protocolo de Pesquisa n.672/03

MARTINS-ORTIZ, Maria Fernanda

VELLOSO, Tânia Regina Grăo

Nome: COSTA-REIS, Andréa

CONSOLARO, Alberto (*)

Observaçäo
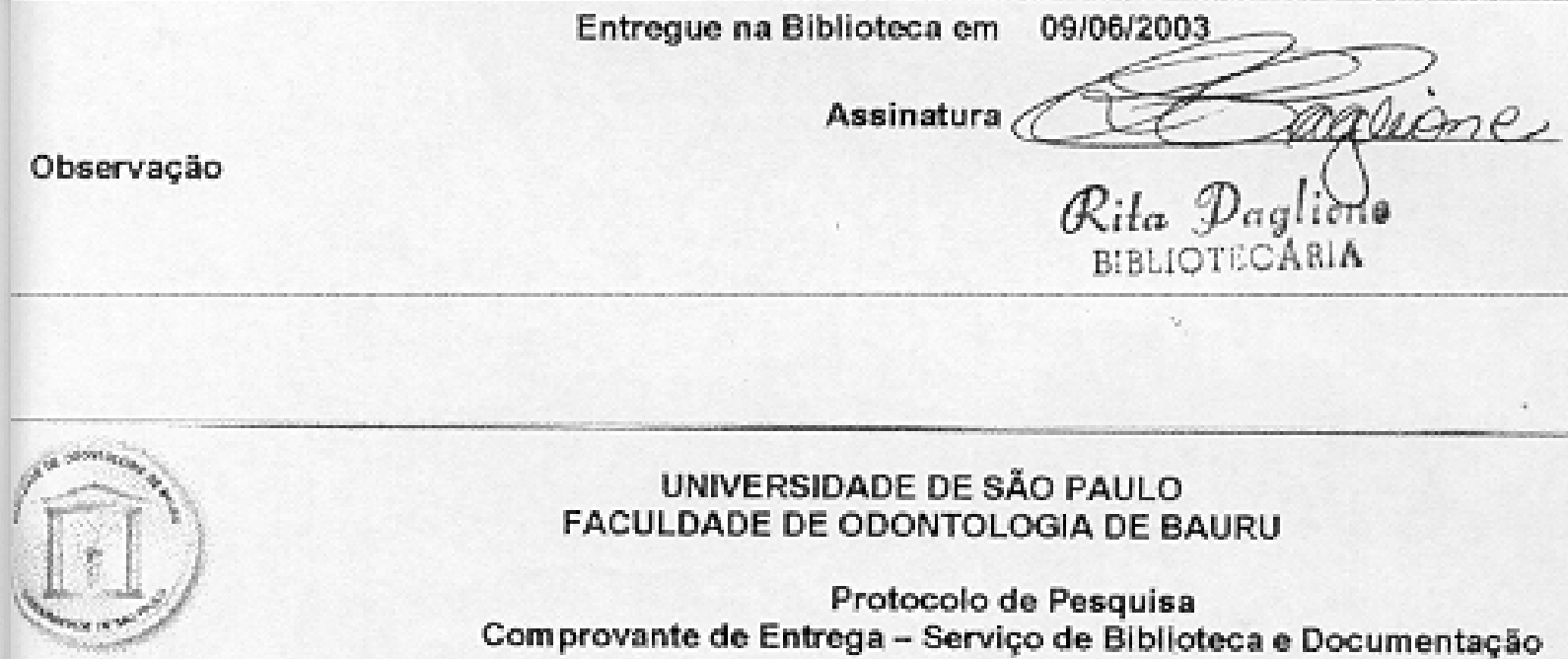

UNIVERSIDADE DE SÃO PAULO

FACULDADE DE ODONTOLOGIA DE BAURU

Protocolo de Pesquisa

Comprovante de Entrega - Serviço de Biblioteca e Documentaçăo

Protocolo de Pesquisa n. 672/03

MARTINS-ORTIZ, Maria Fernanda

VELLOSO, Tânia Regina Gräo

Nome: COSTA-REIS, Andréa

CONSOLARO, Alberto ( ${ }^{*}$ )

\section{Entregue na Biblioteca em 09/06/2003}

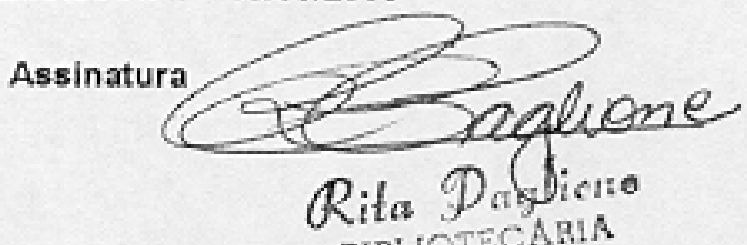




\section{Unesp UNIVERSIDADE ESTADUAL PAULISTA \\ "CÅMPUS" DE ARACCATUBA - FACULDADE DE ODONTOLOGIA CURSOS DE ODONTOLOGIA E DE MEDICINA VETERINÁRIA}

\section{COMISSÃO DE ÉTICA NA EXPERIMENTAÇÃO ANIMAL (CEEA)}

\section{CERTIFICADO}

Certificamos que o Projeto "Determinação do perfil morfológico da movimentação dentária induzida em ratos de 1 a 7 dias", sob a responsabilidade do PROF. DR. ALBERTO CONSOLARO E MARIA FERNANDA MATINSORTIZ / TÂNIA REGINA GRÃO VELLOSO está de acordo com os Princípios Éticos na Experimentação Animal adotado pelo Colégio Brasileiro de Experimentação Animal (COBEA) e foi aprovado pela CEEA em reunião de 11/06/2002.

Araçatuba, 12 de junho de 2002.

Prof. Ass. Alexandre-Lima de Andrade

Presidente 


\section{Universidade de São Paulo \\ Faculdade de Odontologia de Bauru}

Al. Dr. Octávio Pinheiro Brisolla, 9-75 - Bauru-SP - CEP 17012-901 - C.P. 73

PABX (0XX14)3235-8000 - FAX (0XX14)3223-4679

Comíssäo de Éfica no Ensino e Pesquisa em $\mathscr{A}_{\text {nimais }}$

Of. $n^{\circ}$ CEEPA 05/2004

Bauru, 16 de fevereiro de 2004.

Senhor Professor,

Em atençăo a sua consulta referente à pesquisa desenvolvida sob sua orientaçắo, intitulada "Análise microscópica dos fenômenos teciduais da movimentaçáo dentária induzida em ratos no período de um a sete dias", de autoria da C.D. Andrea Reis da Costa, tendo em vista seu início ser anterior à conscituição desta Comissão, informamos que, não cabe, no momento, a análise ética da referida pesquisa.

Sendo o que nos apresenta para o momento, despedimo-nos,

Atenciosamente,

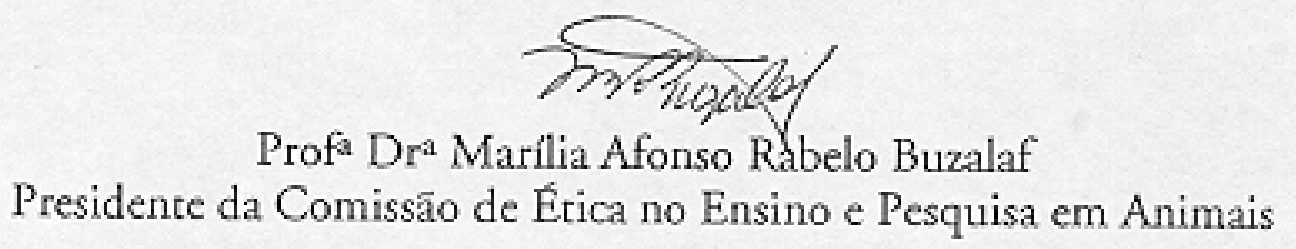

1

$\mathrm{Ilm}^{\circ}$ Sr. Prof. Dr. Luís Antônio de Assis Taveira

DD. Docente do Departamento de Estomatologia 